
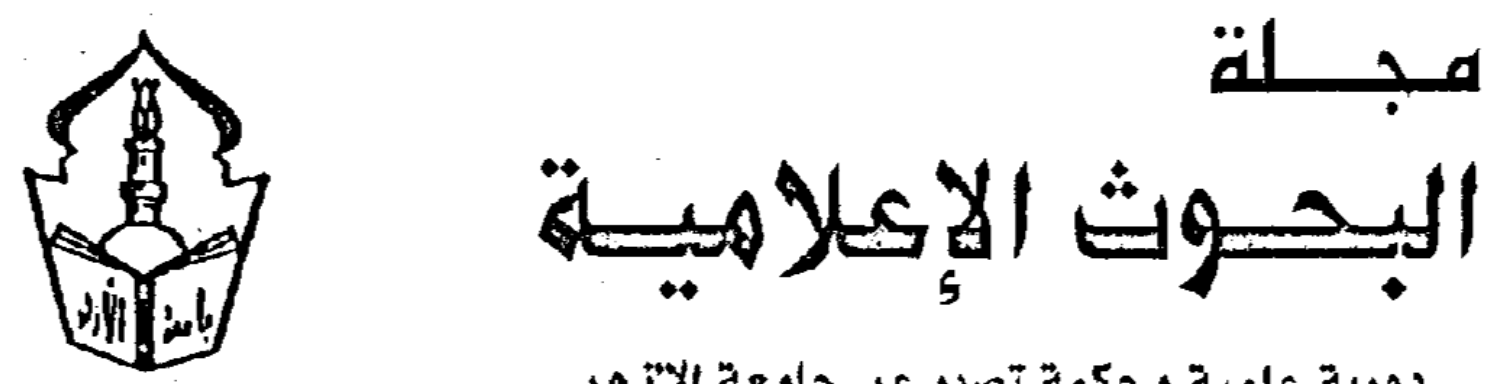

دورية علمية محكمة تصدر عن جامعة الآزهر

$$
\text { رئيس مجلس الإدارة : }
$$

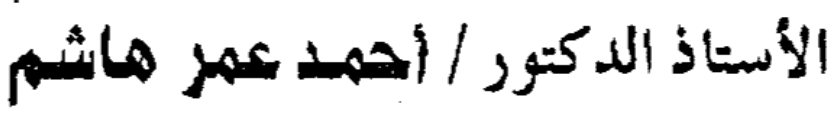

$$
\text { رئيس التحرير: }
$$

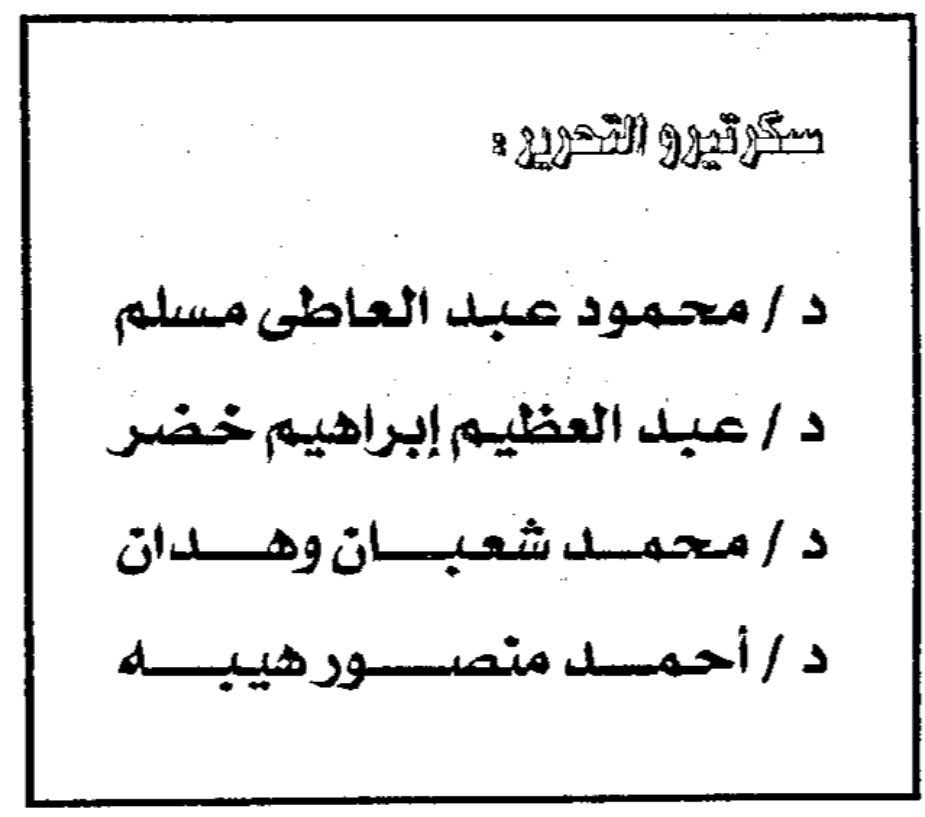

$$
\text { محهود حسن الليثى النیى }
$$

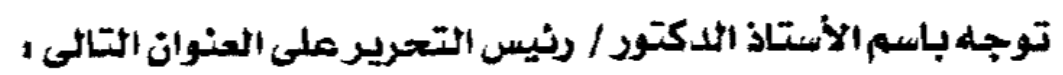

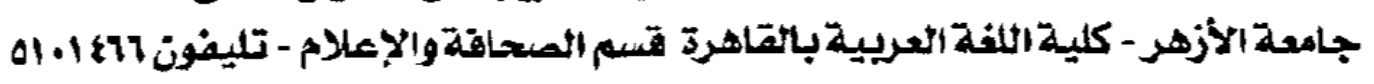




\section{هينُة المحكمين}

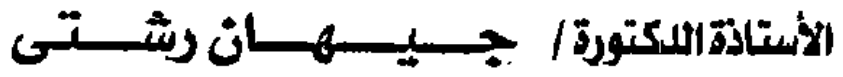

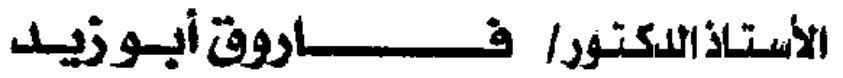

الأستاذالاكنور/ محيى الدين عبد الحليهم

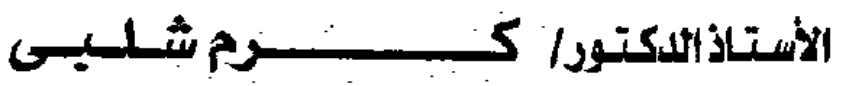

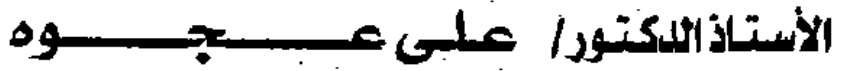

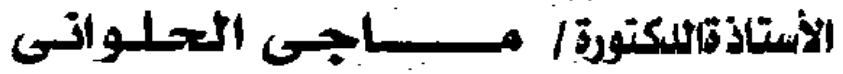

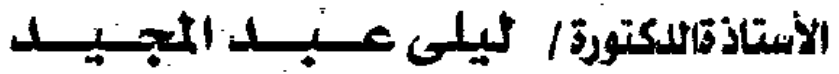

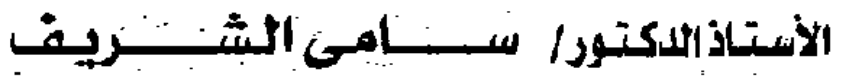

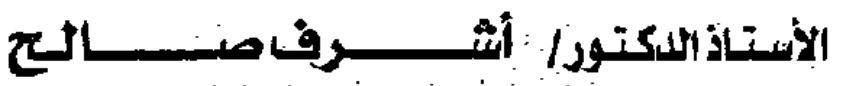

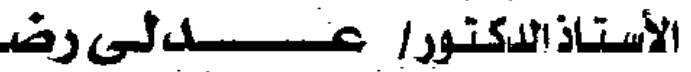

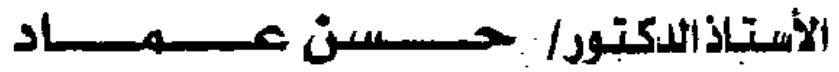

جميع الآراء الواردة فى هده المجلة تعبر عن راى صاحبها ولا تعبر عن راى المجلة

العلدد العاشر

ينتاير 1999 


\section{المثهربس}

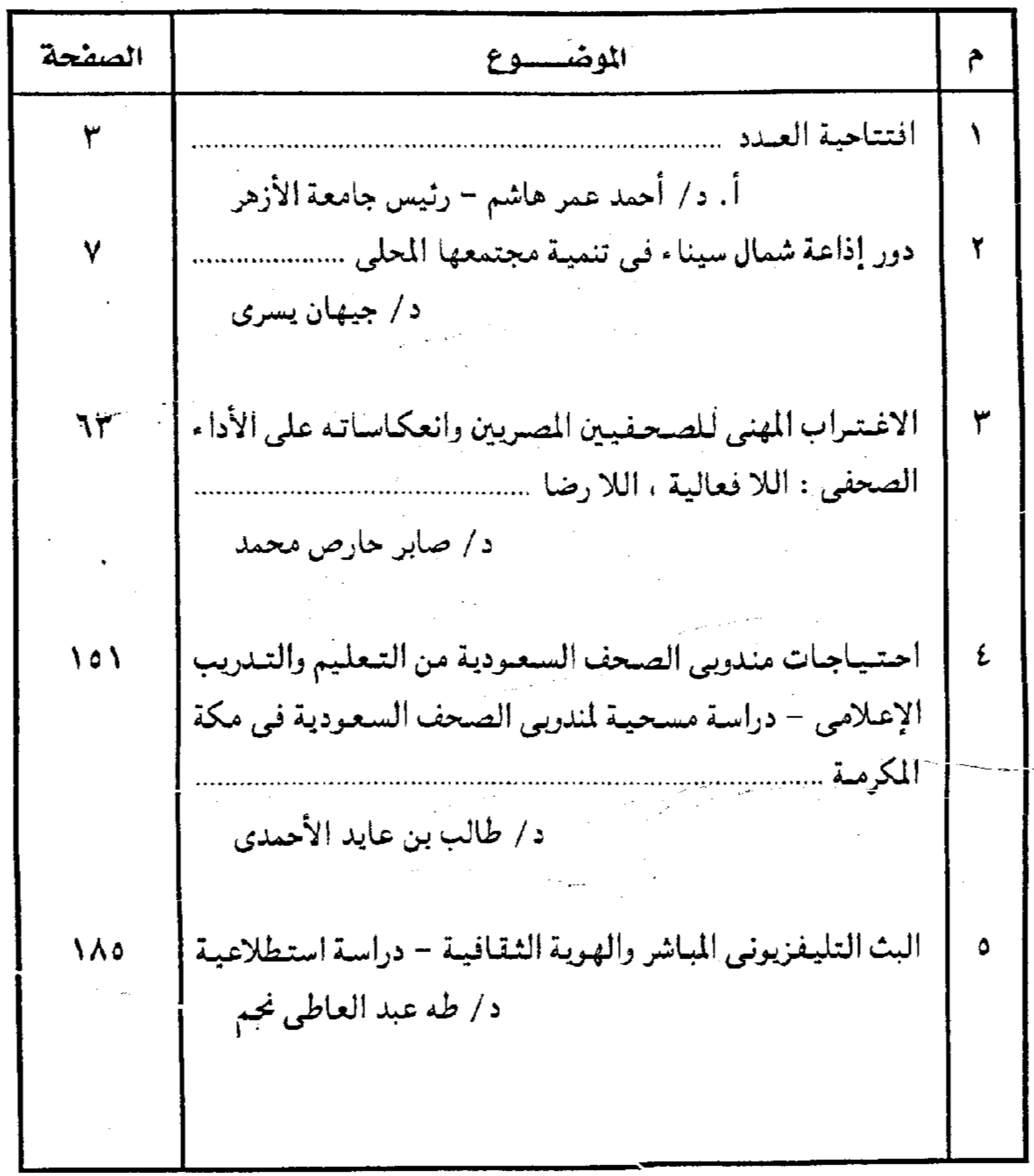




\section{البث التلمزيوثى المباشروالهوية الثقافية العريية

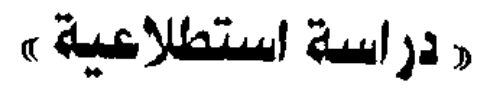

دكتور

(*)

\section{المقلهة :}

البث التليفزيونى المباشر عبر الأقمار الصناعية نتيجة حتـيـة لتطور تكنولوجيا

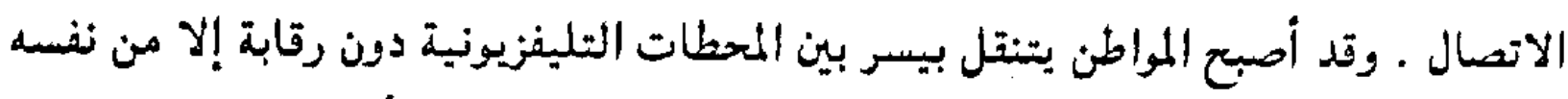

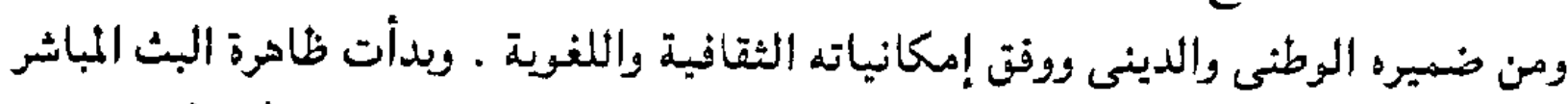

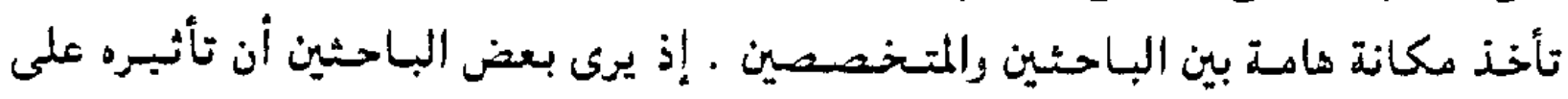

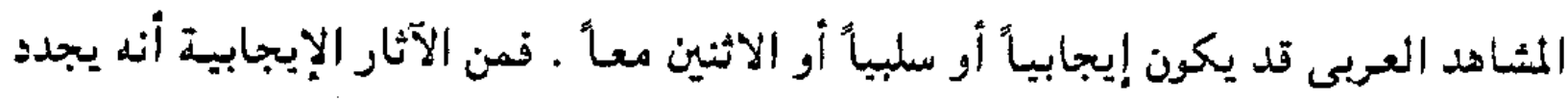

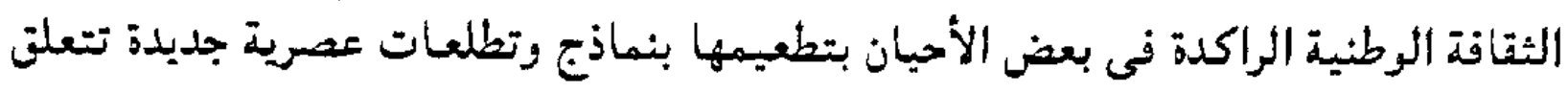

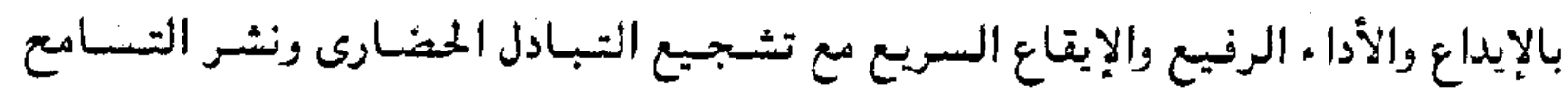

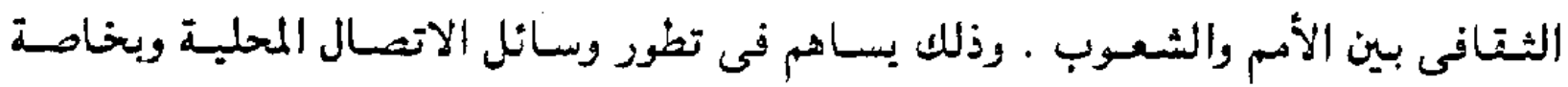

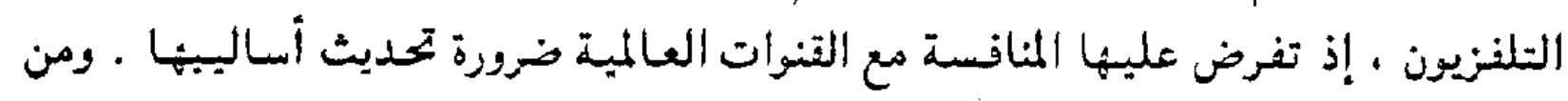

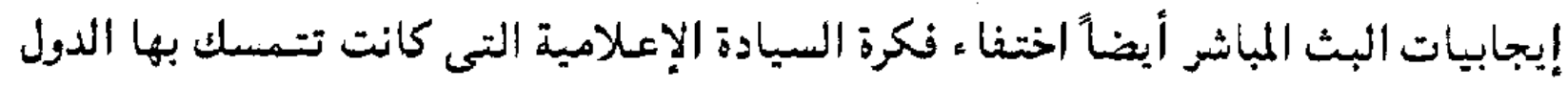

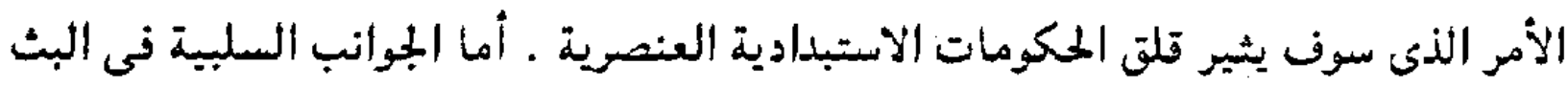

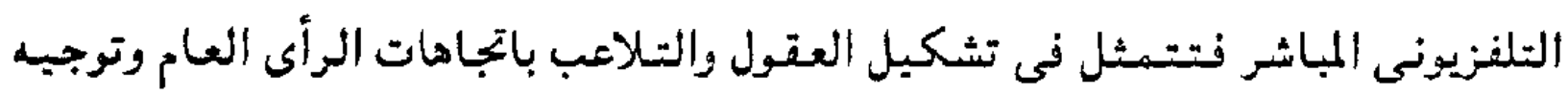

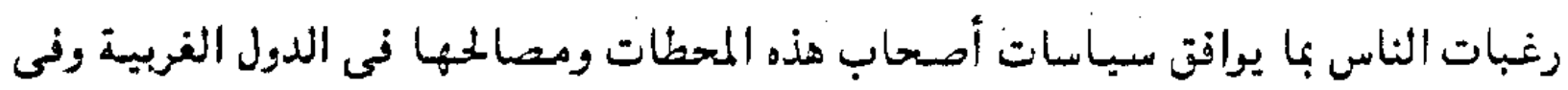

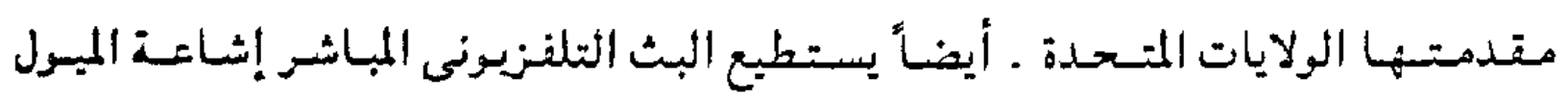

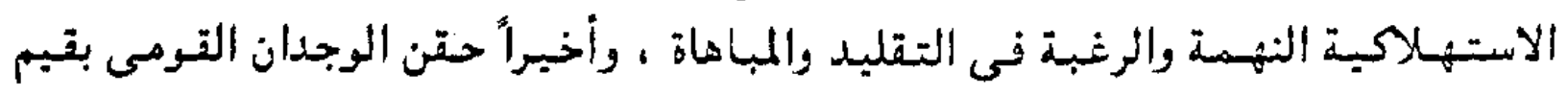

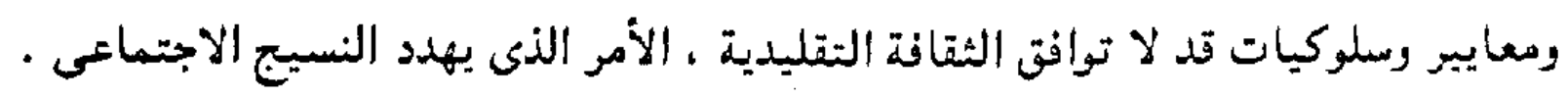
وقد استقطبث مسألة الاستقبال التلفزيونى المباشر بواسطة الأطباق مئذ التسعبنيات

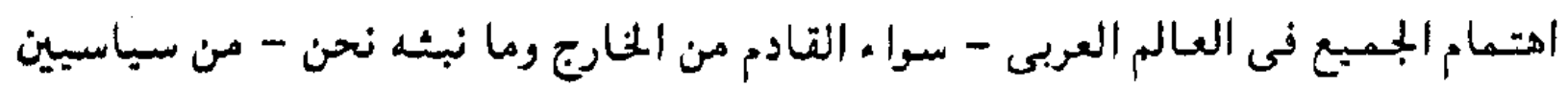

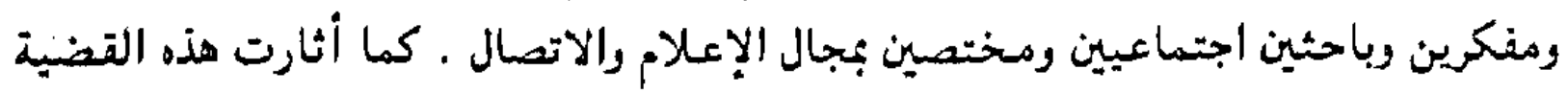

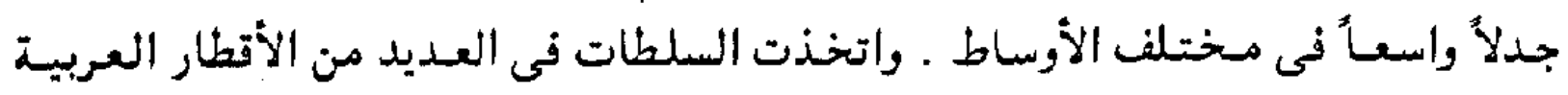

(†) المدرس بئعبة الإعلام - كلبة الآداب - جامعة الإسكندرية . 


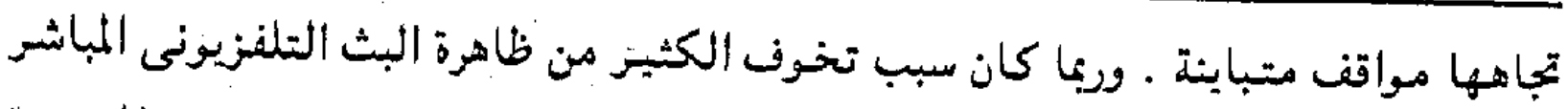

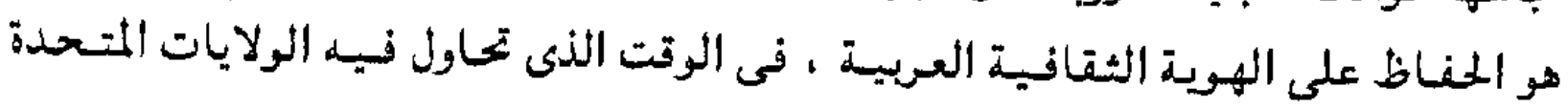

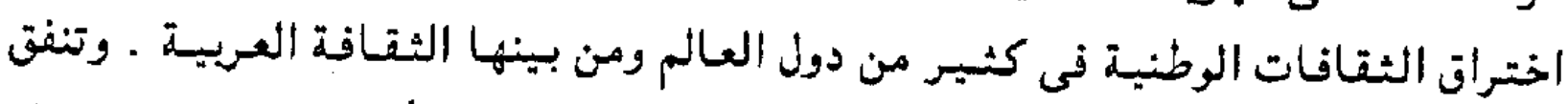

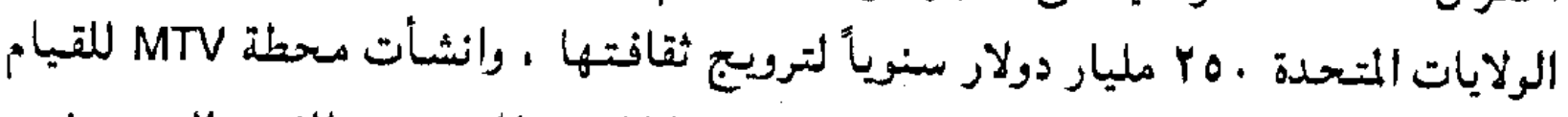

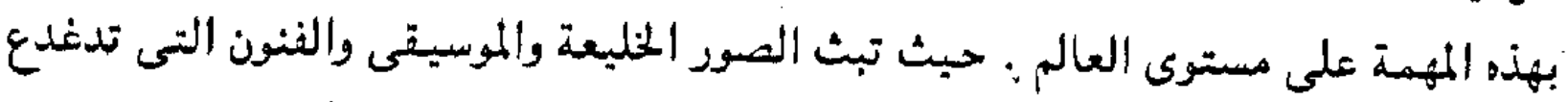

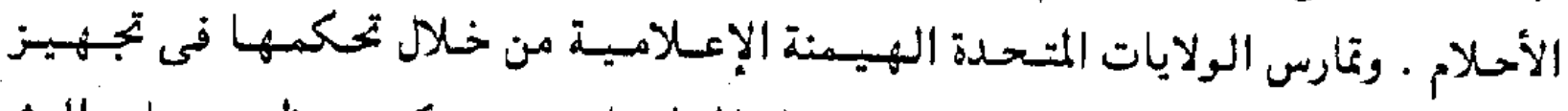

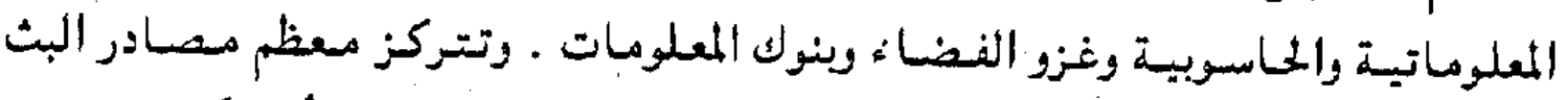

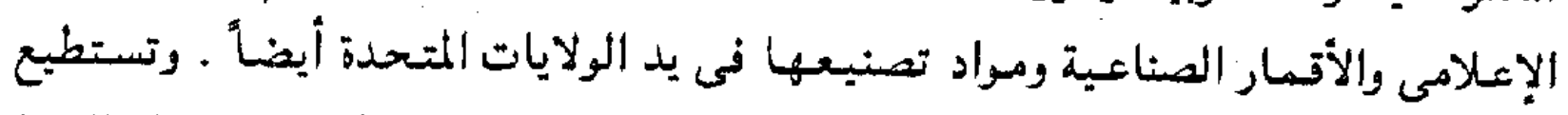

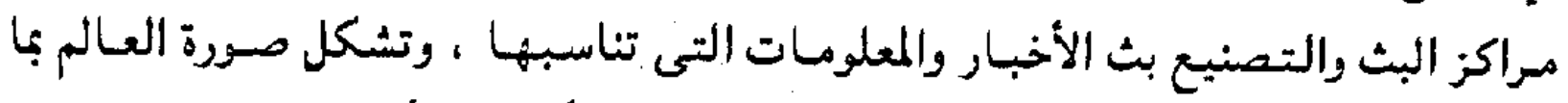

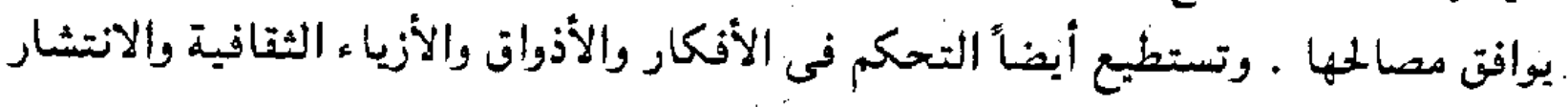

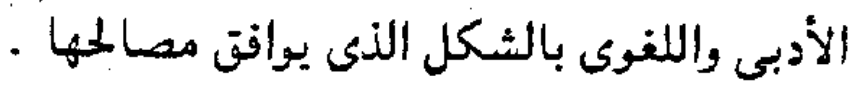

\section{أهداف الدراسة}

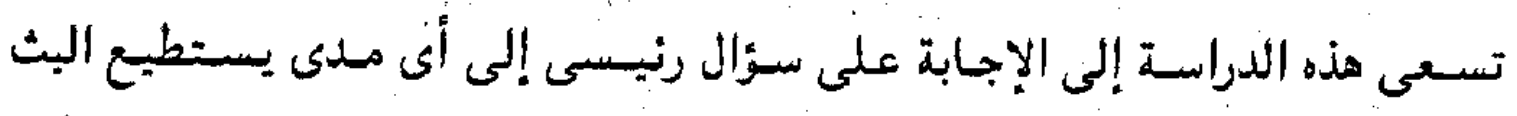

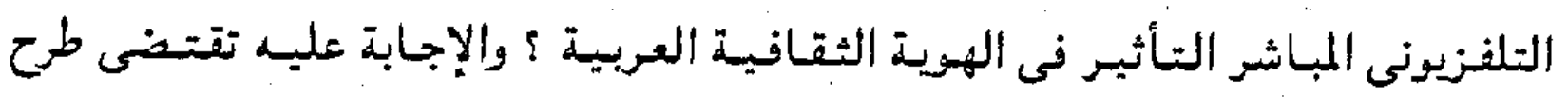

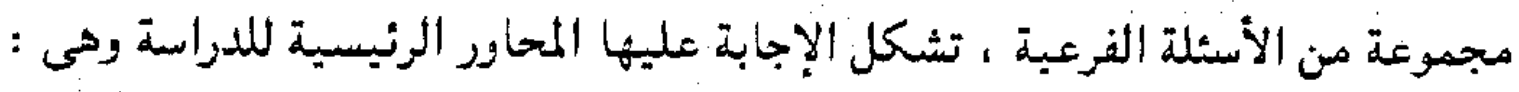
1 - ما الخصاتص التى تيز الثلفزيون باعتباره وسيلة ثقافية ؟ r - كيف يستطيع البث التلفزيونى المباشر عولمة المجتمع إعلامياً وثقافياً ؟ r - ما تأثير البث التلفزيونى المباشر فى الهوية الثقافية العربية ؟ ع - ما نتانج تأثير البث التلفزيونى فى الهوية الثقافية المصرية ؟

\section{المثهومات الأنساسية النية}

\section{1 - الموية الثقانية Cultural identity}

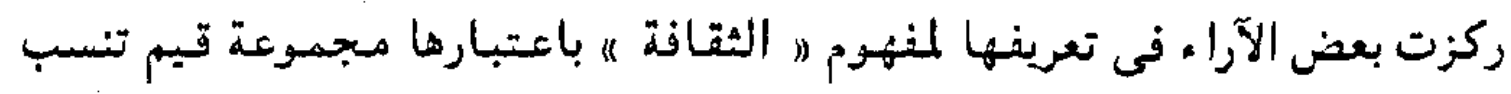

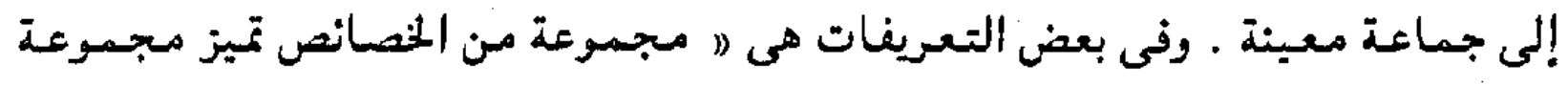

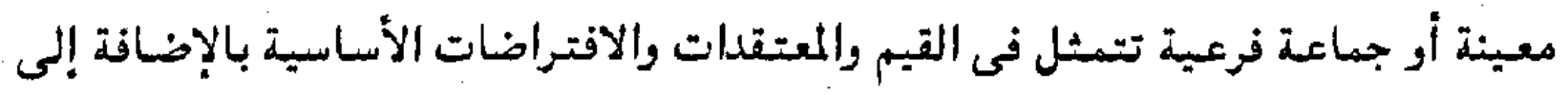

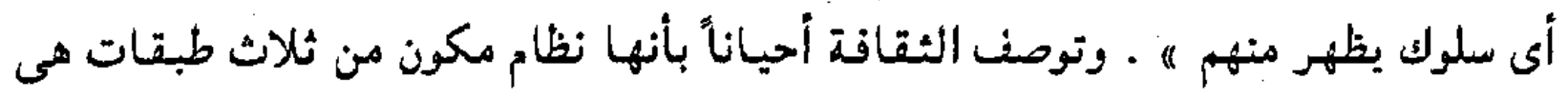

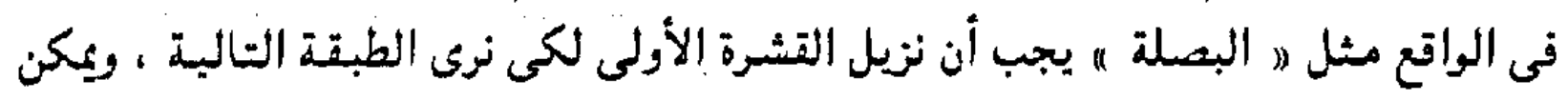


تفسير الطبقات الثبلاث للثقافة بأن الطبقة الخارجية مصنوعات يلدية ومنتجات ، وهى

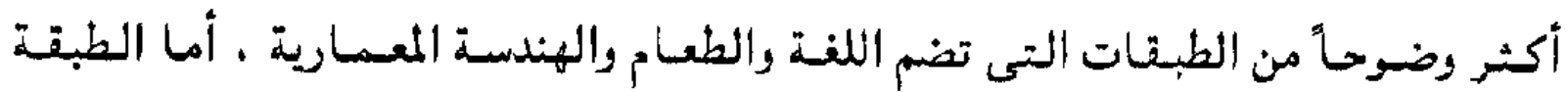

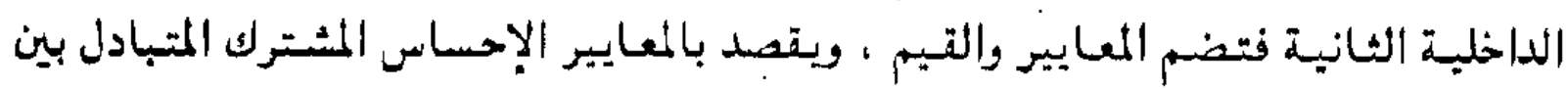

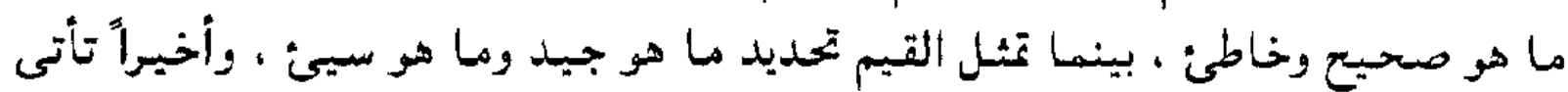

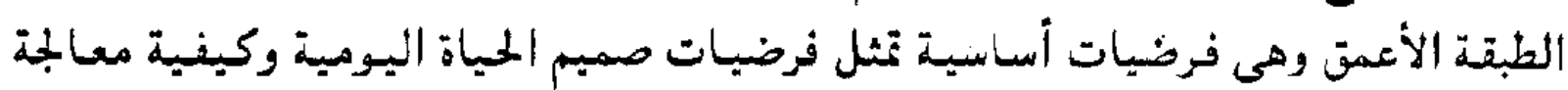

(1) مشاكله

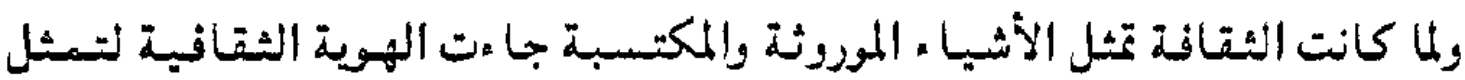

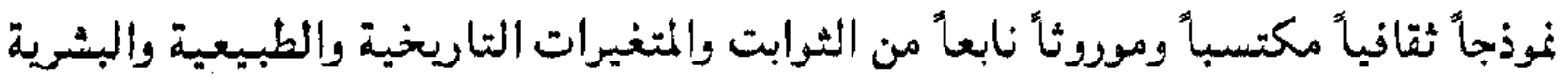

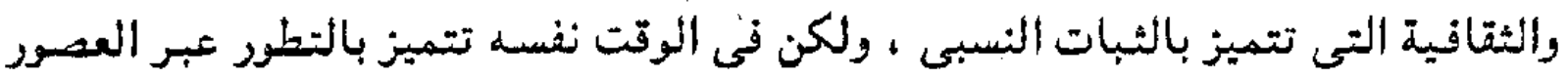

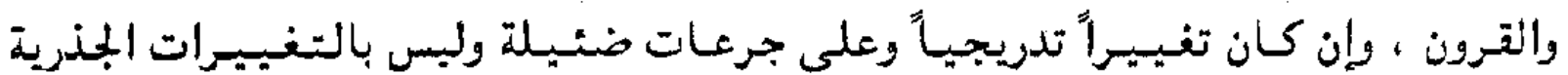

(v) الحساوة

وإذا حـاولنا تحديذ هويتنا الثـــانيـة يجب أن نحدد من نحن وكيف ننظل للناس .

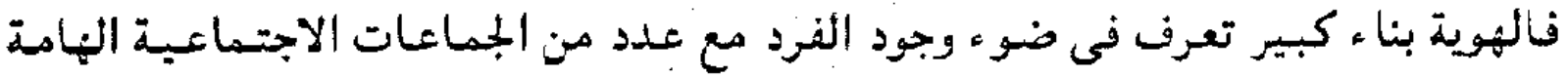

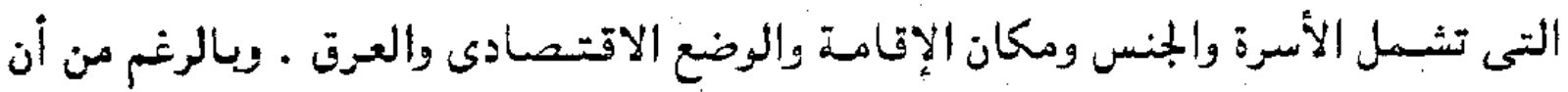

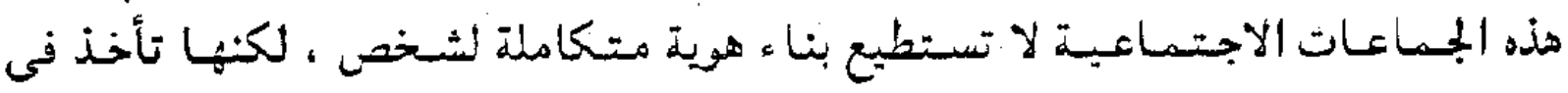

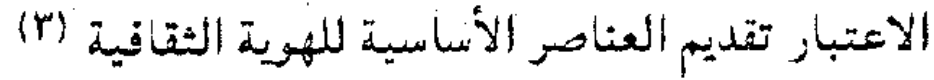

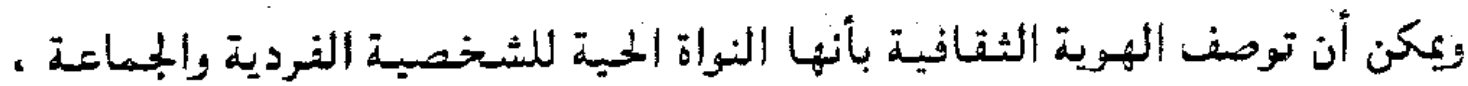

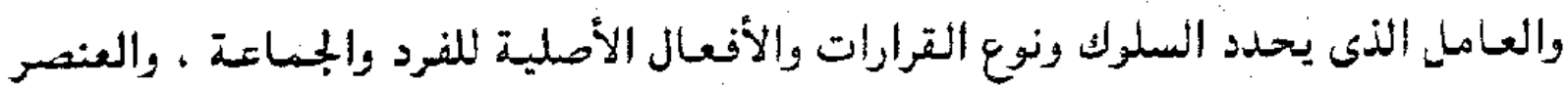

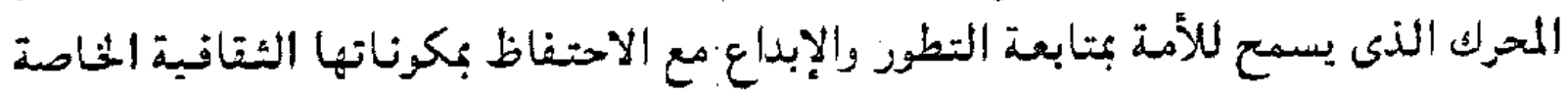

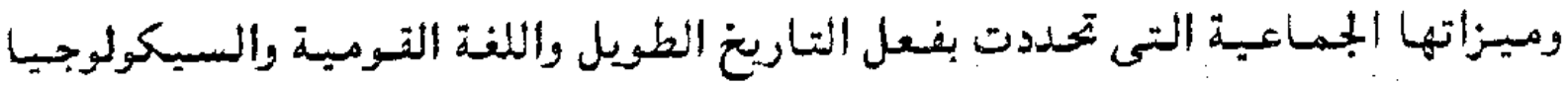

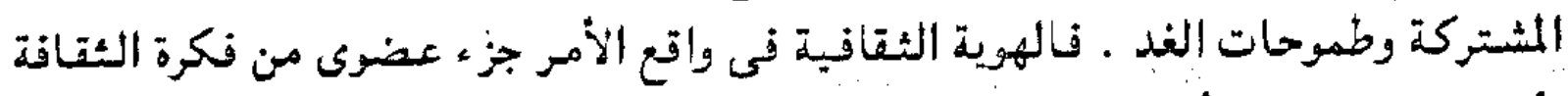

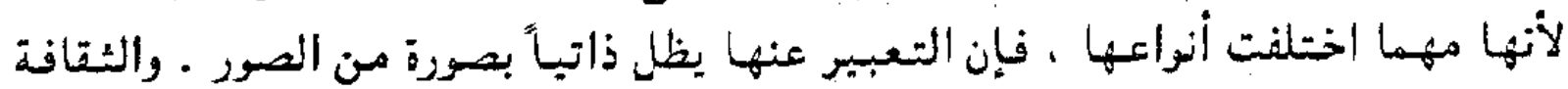

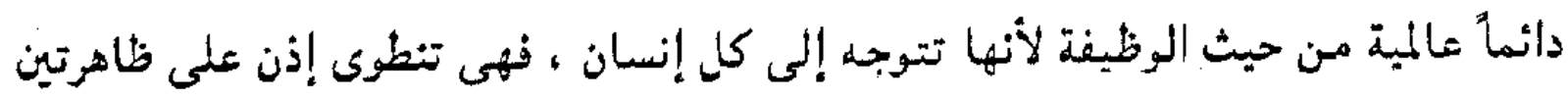

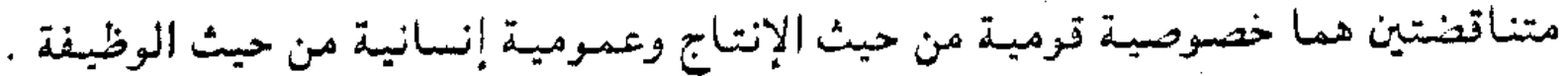

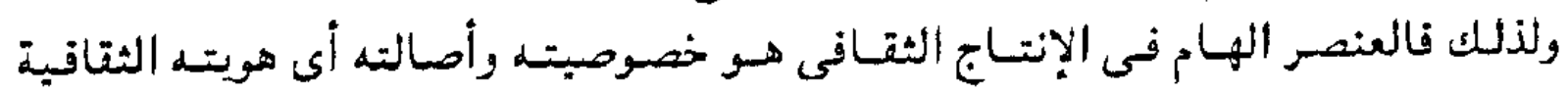
(1) التـى تمـيزه

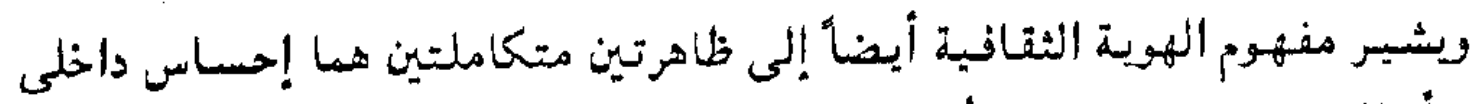

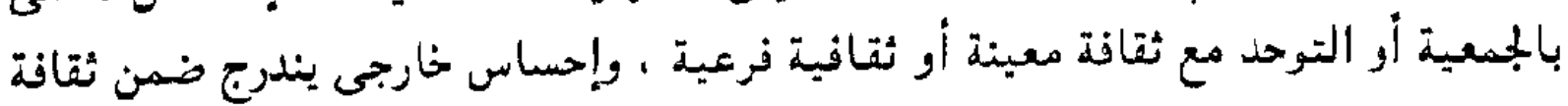


معينة كى تشارك إحساس ما هو مثترك مع الثقافات الأخرى وما يميزه عنها ـ نالثقافة

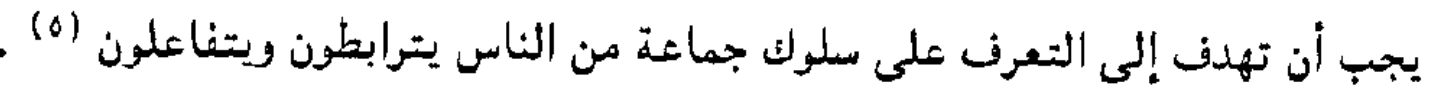

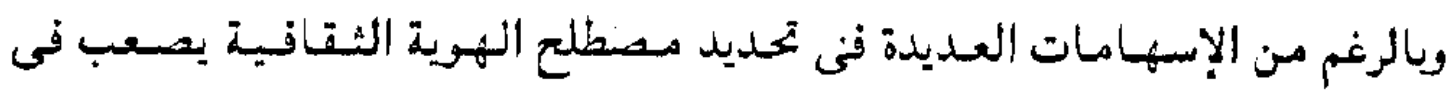

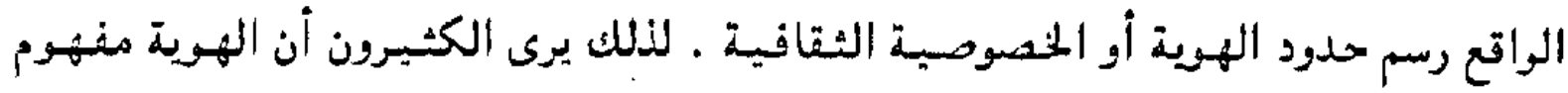

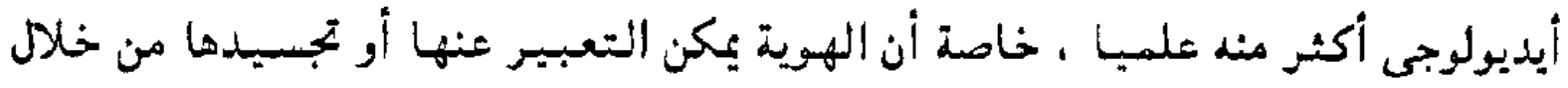

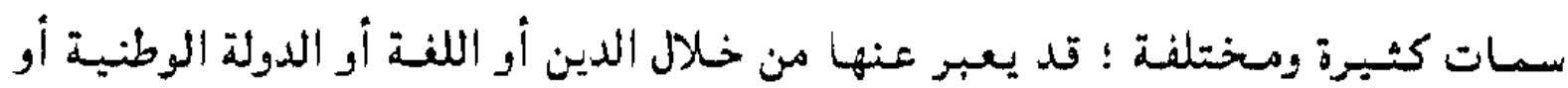

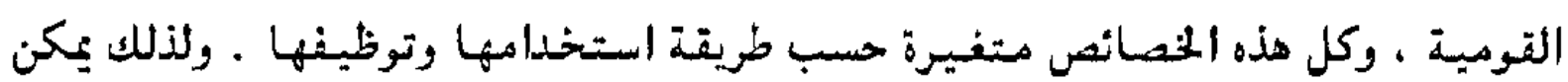

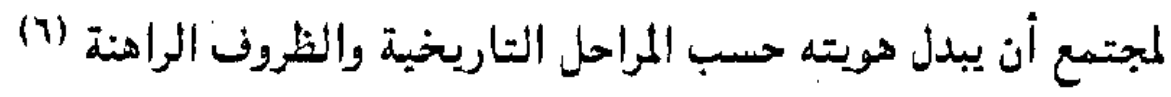

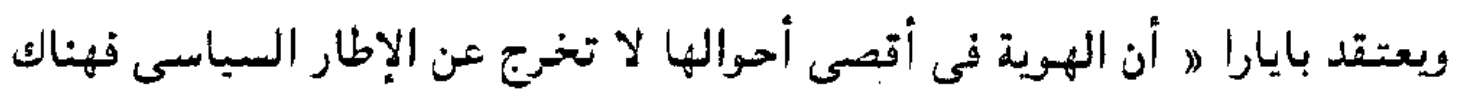

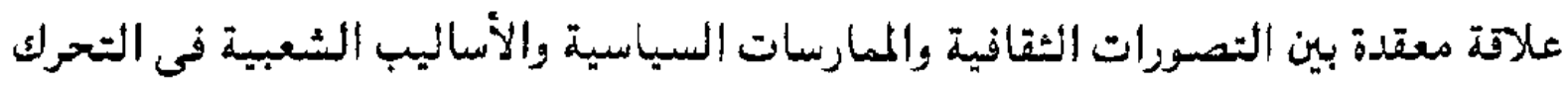

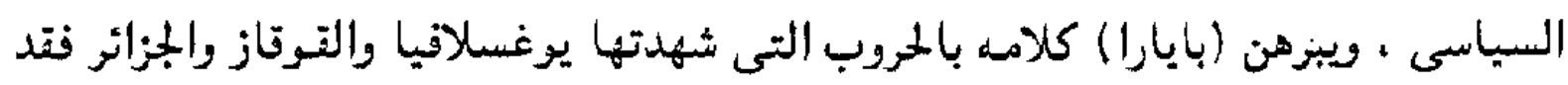

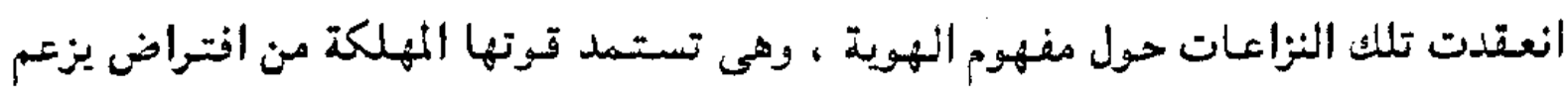

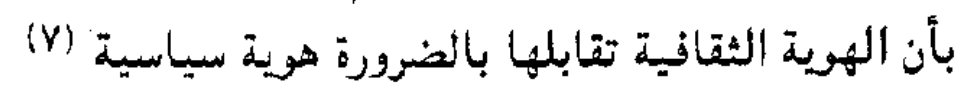

ونخلص مما سبق إلى القول بأن الههية الثقانية هى طريقة حباة ( أسلوب حباة )

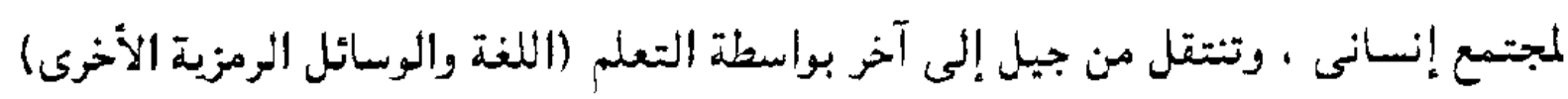

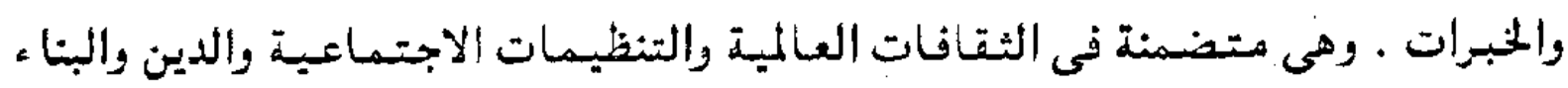

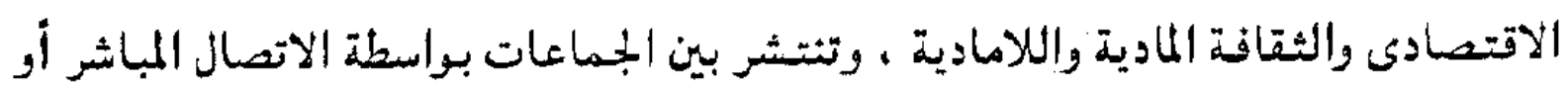

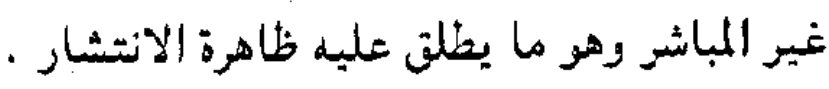

إذن الهوية الثقافية لبست نمطاُ جامداً ، ولكنها تــــبز بالتطور عبر العصور

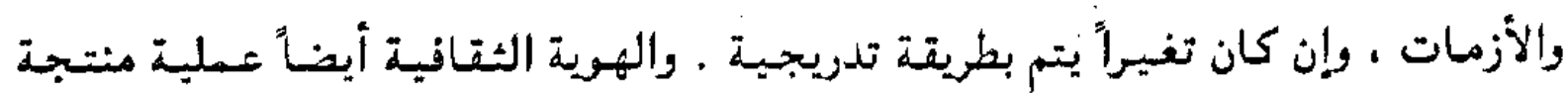

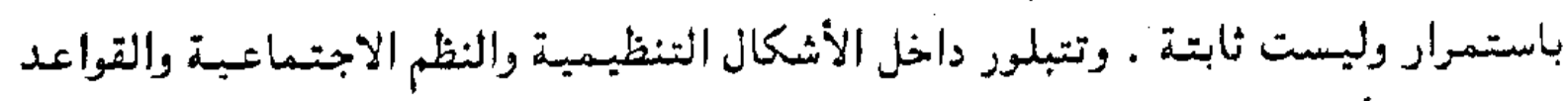

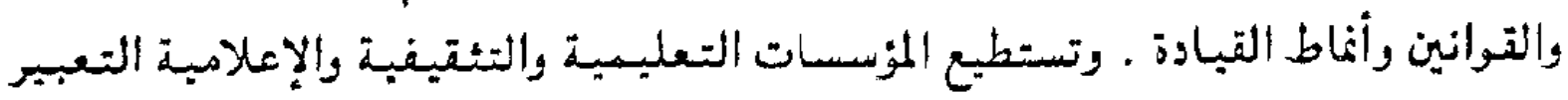

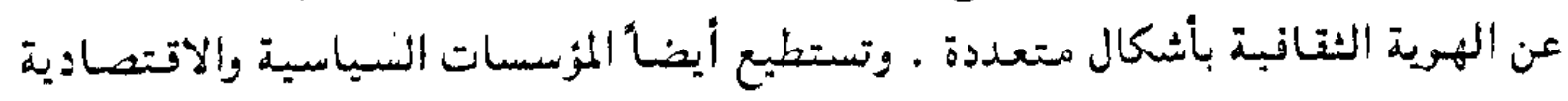

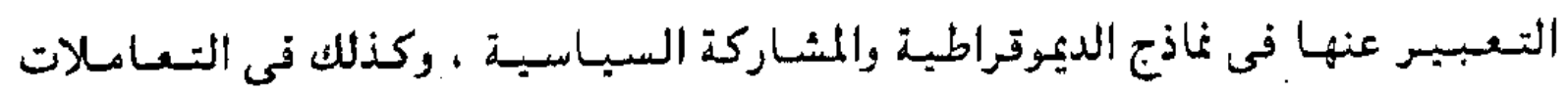

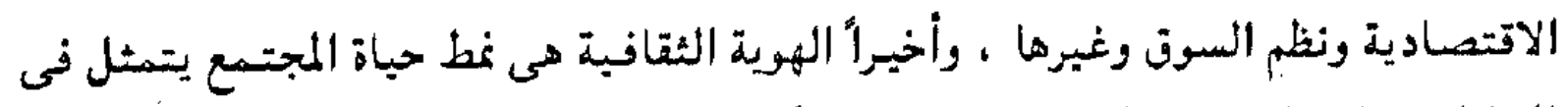

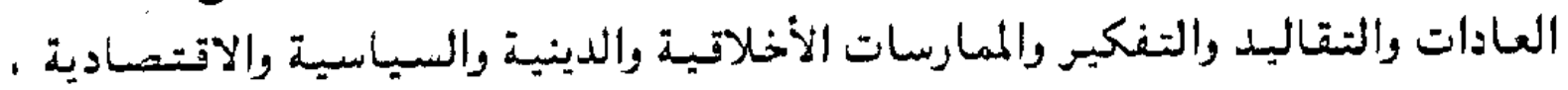

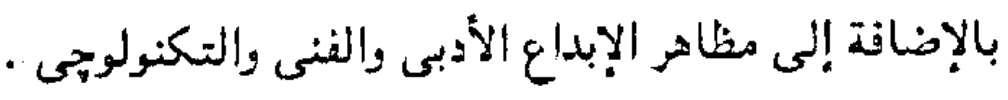




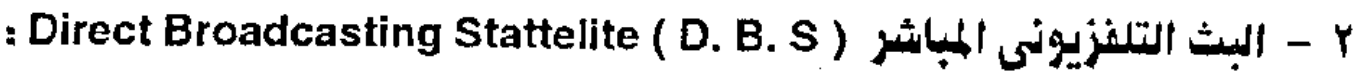

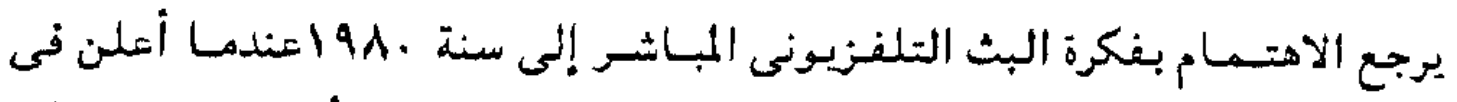

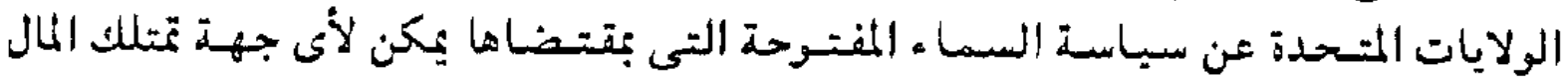

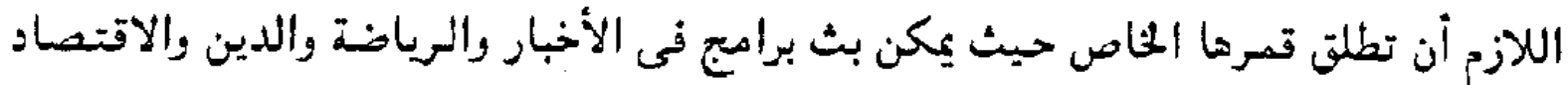

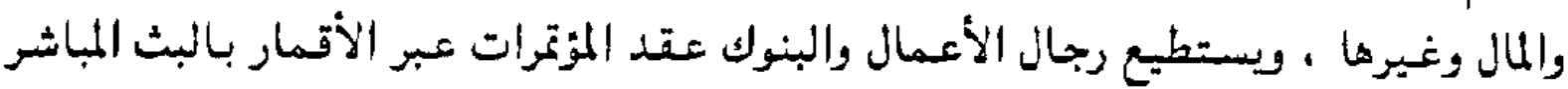

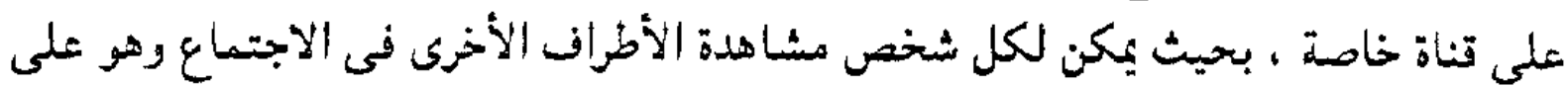

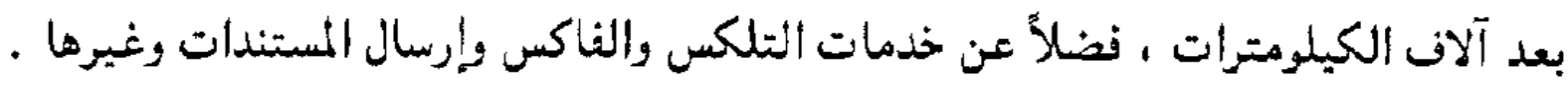

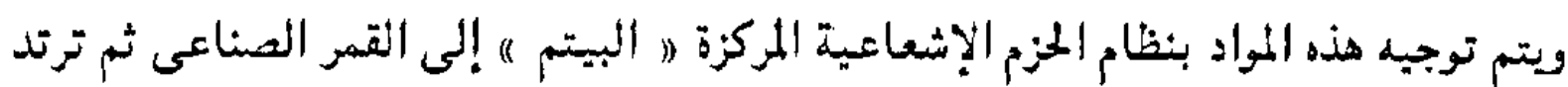

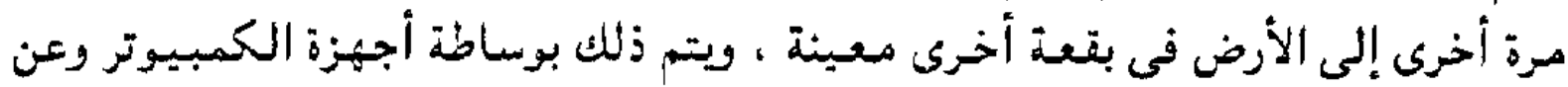

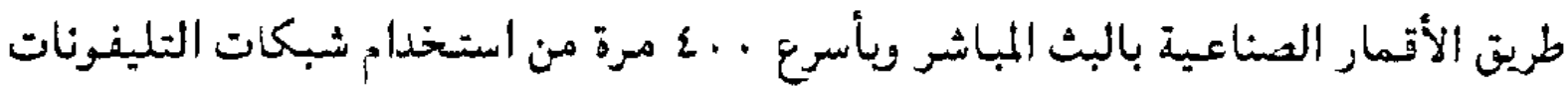
الأرضية (A)

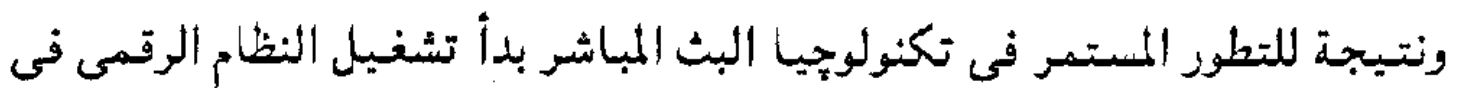
الإذاعة والتلفزيون وكذلك الإنترنت ، وذلك لتشكيل عالم جلديد في الاتصال الجـاهيرى .

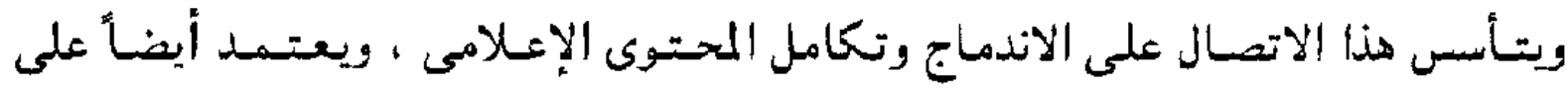
الاتصـال عـن بعـد . ويتـضـــن التلفزيون الأرضى الرقـمى Digital Terrestail Television

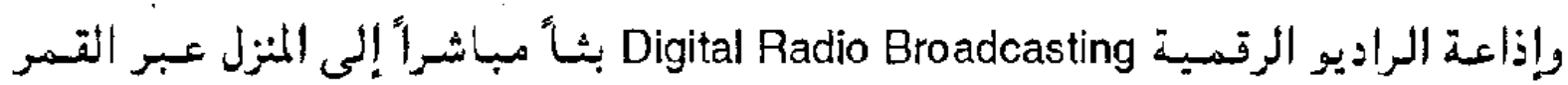

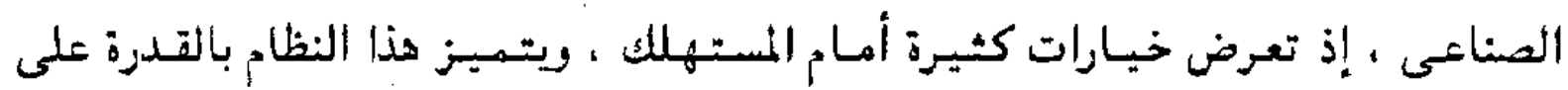

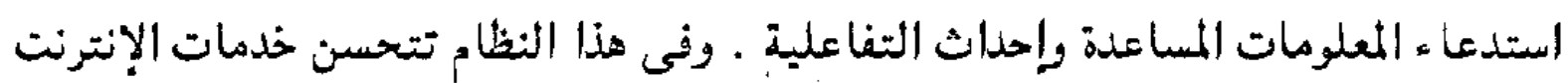

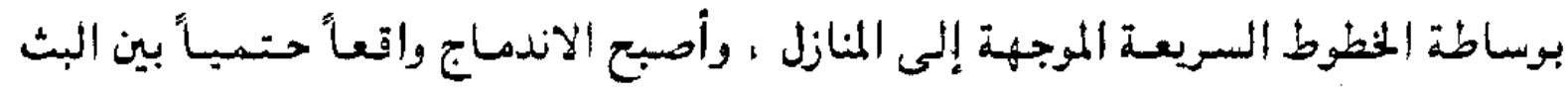

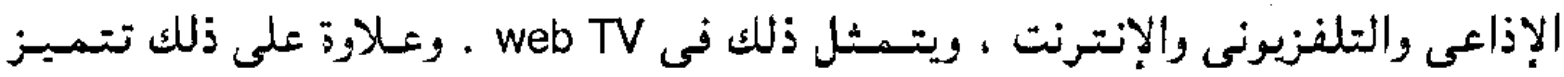

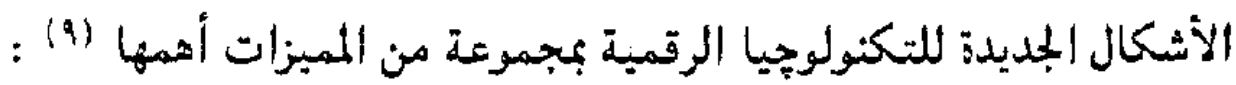
1 - اختيار أحسن البرامج التى تتضمن الثقدرة على إدخال برامج من وإلى العالم . Y - التفاعل الكبير بين الجهـهور والوسيلة مع القدرة على التتزويد الآنى والتغذية المرتدة

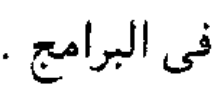

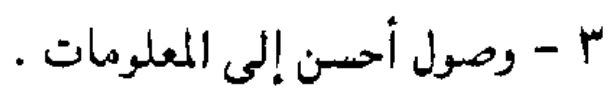

ع - القدرة على إدارة الأعمال متضمنة الصفقات البنكية والشراء من المنزل .

$$
0
$$

1 - High Definition TV تلفزيون ذو مقدرة عالية 
وقد استقطبت مسألة الاستقبال التلفزيونى المباشر بواسطة الأطباق منذ التسعينيات

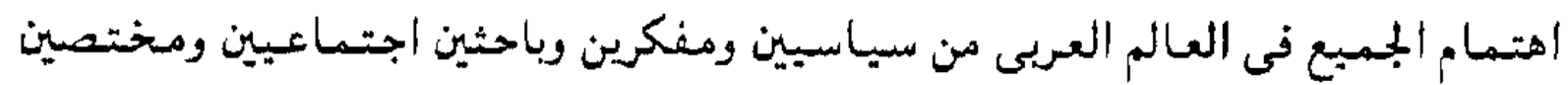

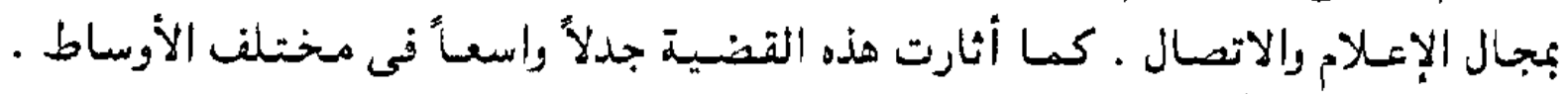

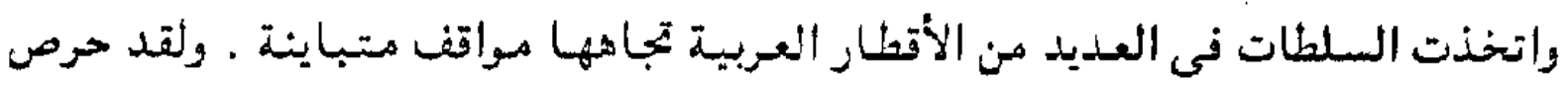

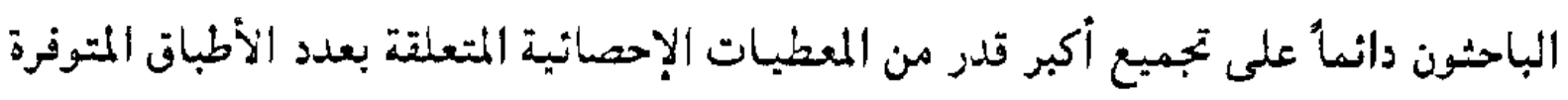

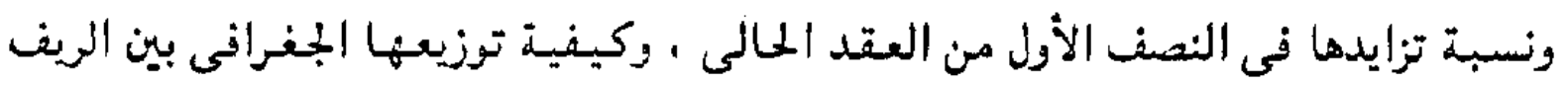

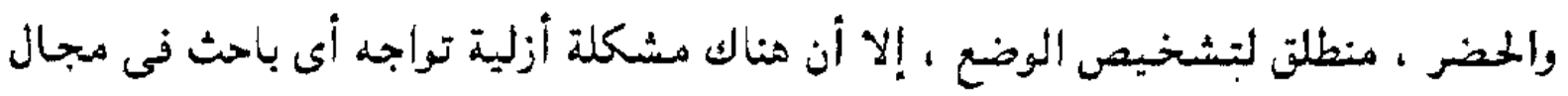

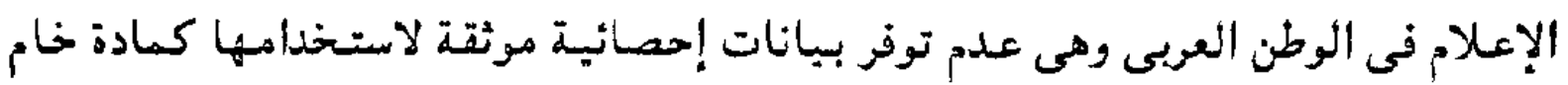

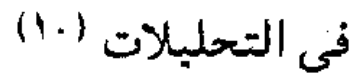

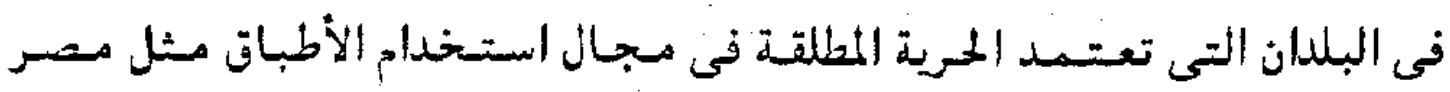

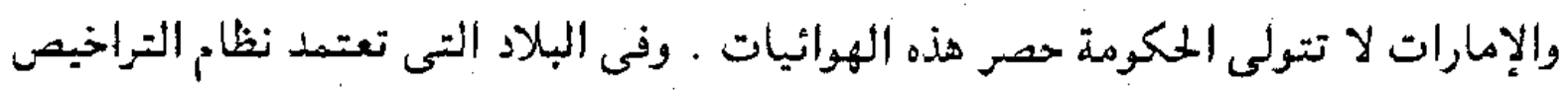

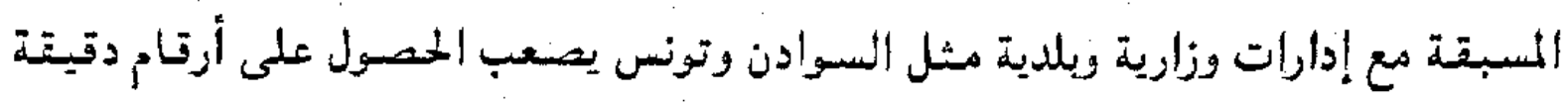

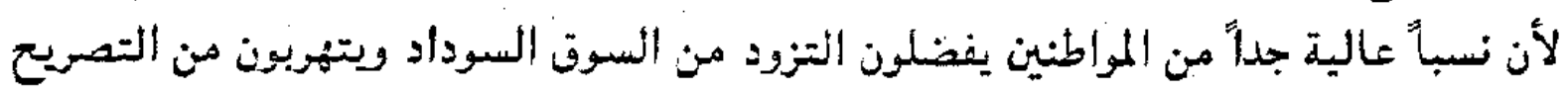

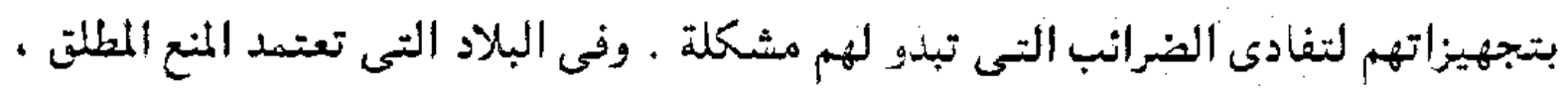

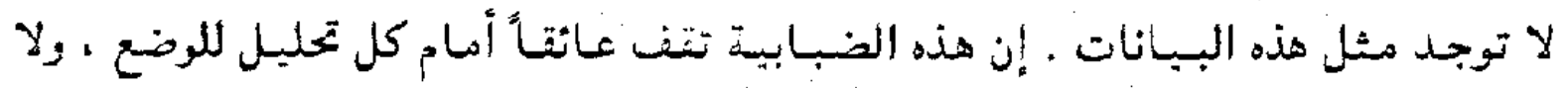

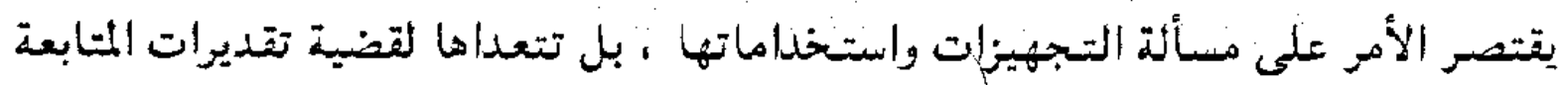

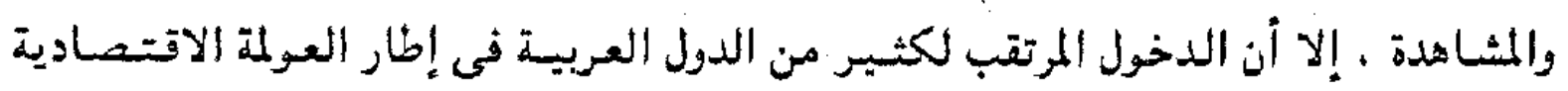

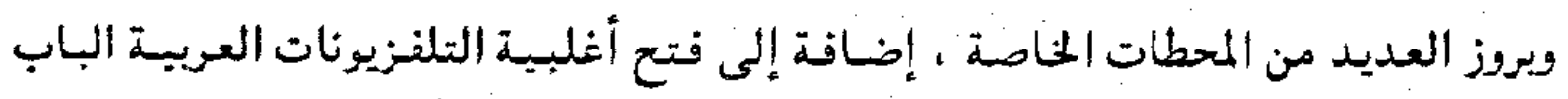

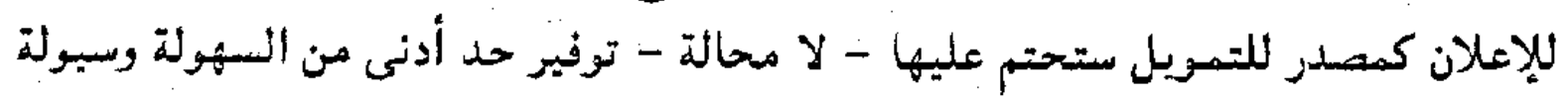

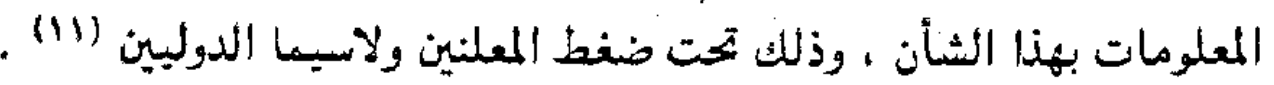

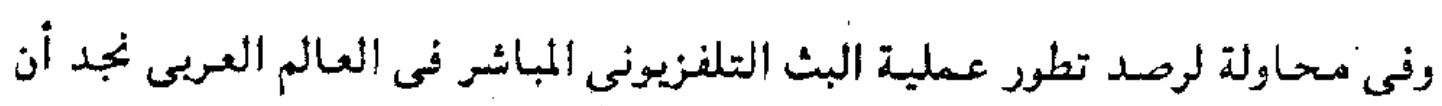

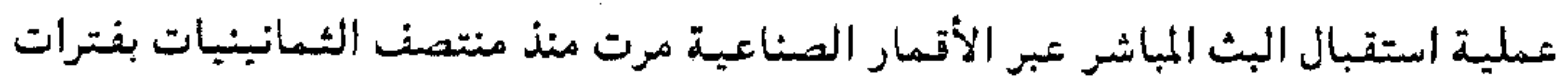

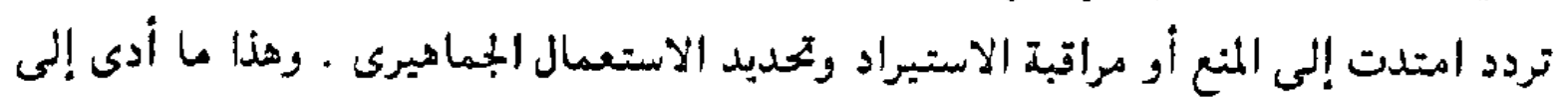

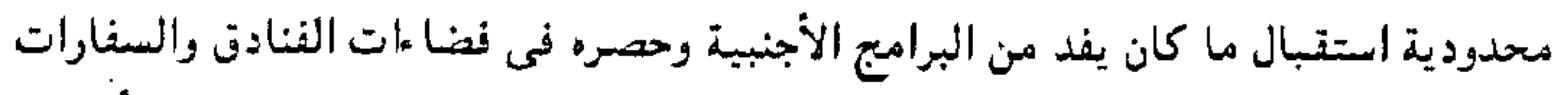

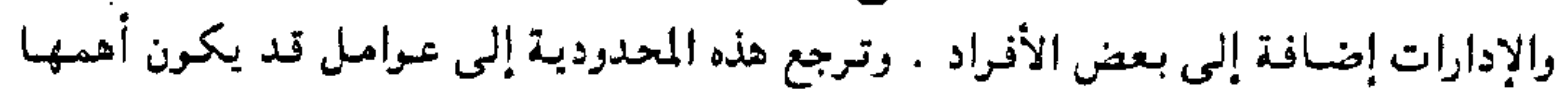

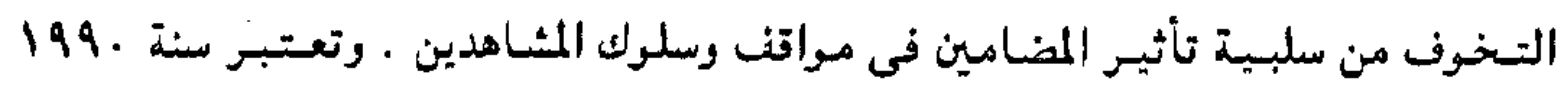

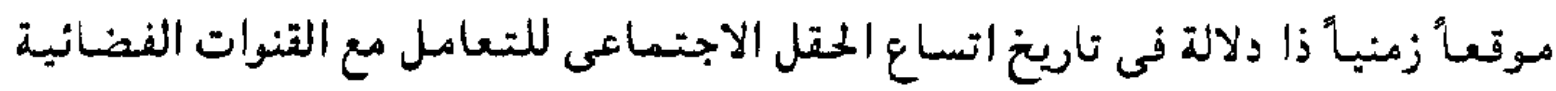

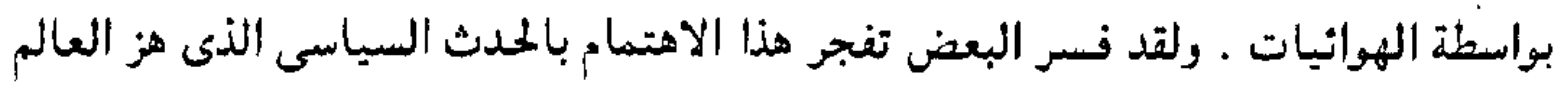




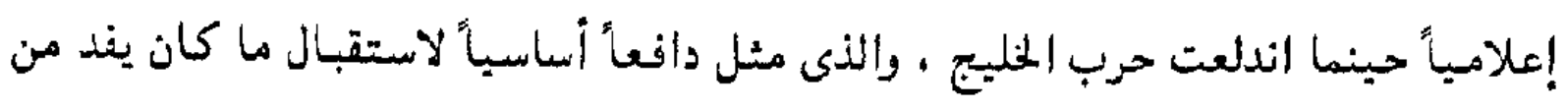

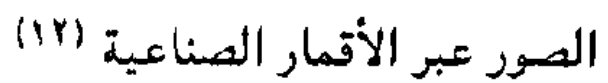

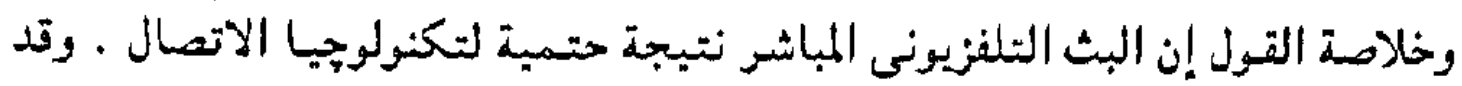

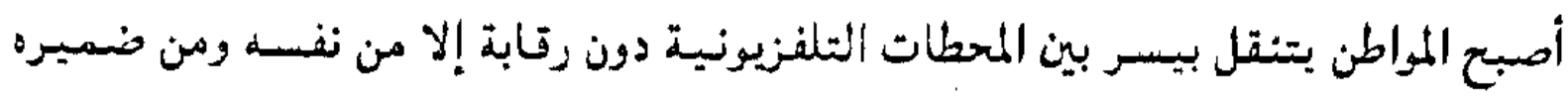

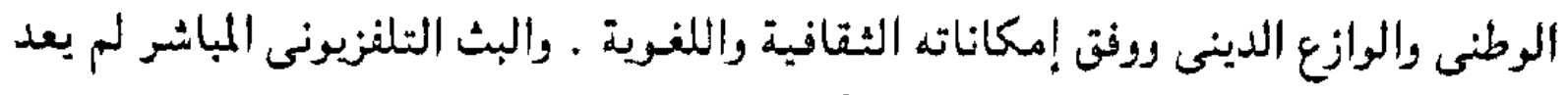

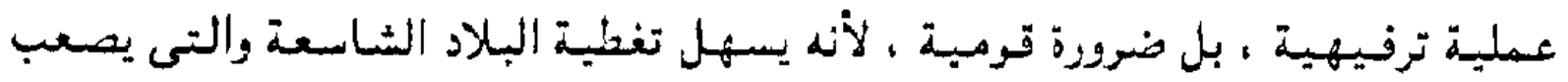

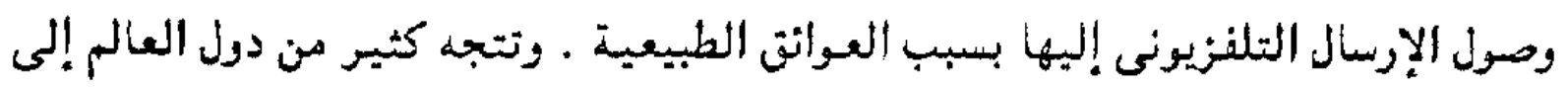

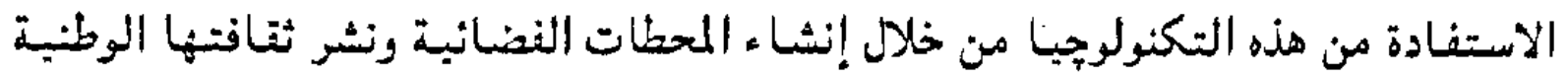

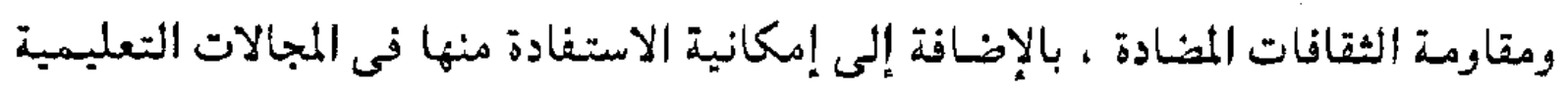

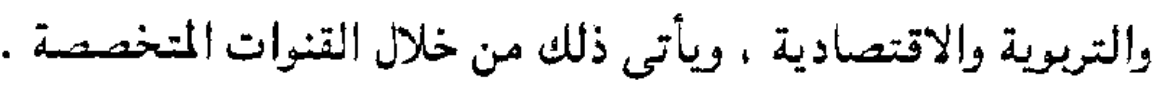

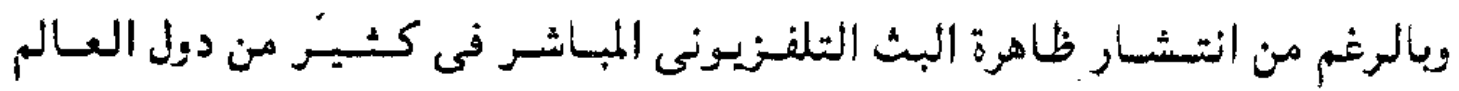

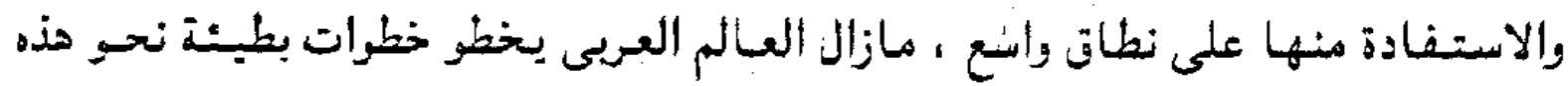

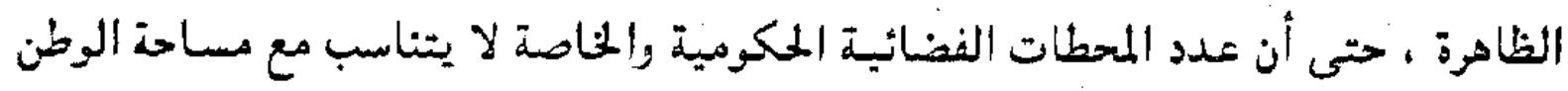

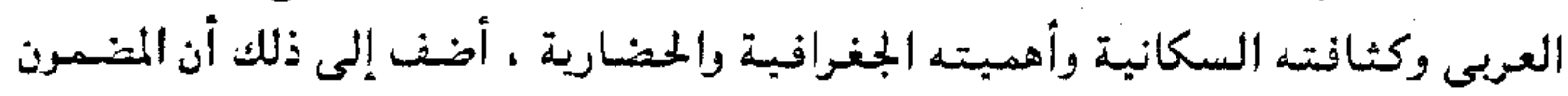

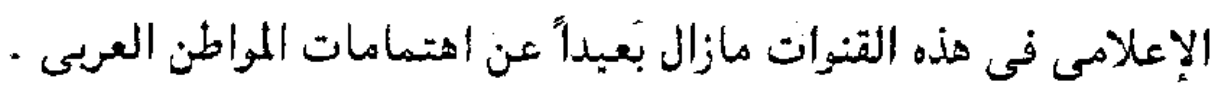

\section{ع - الإجر أيات المثنجية للدر اسلة :}

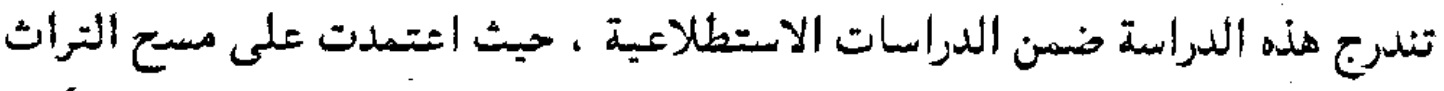

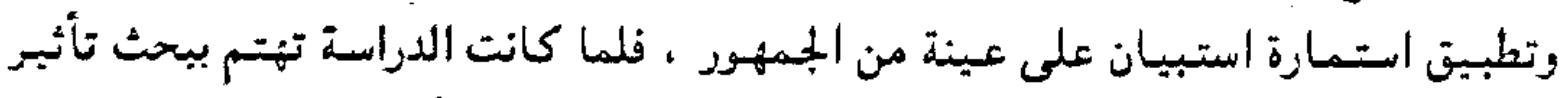

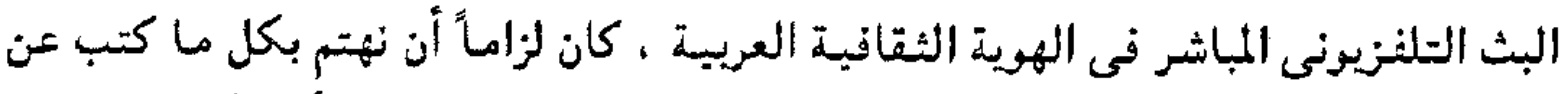

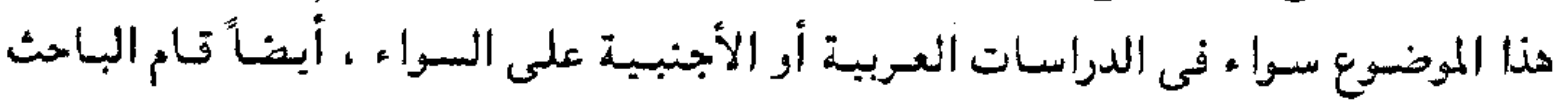

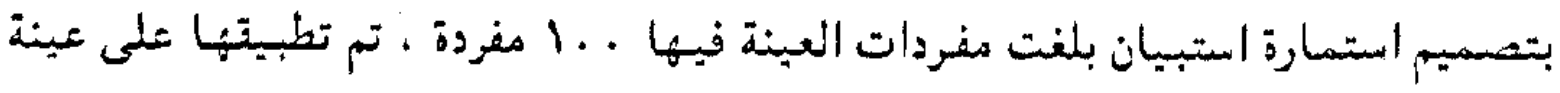

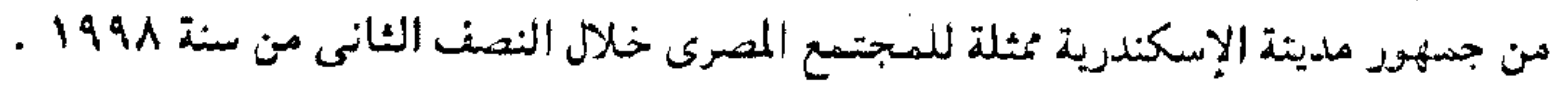

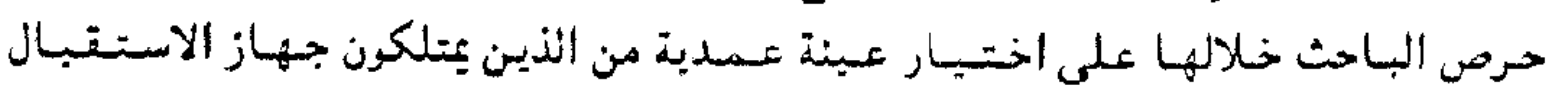

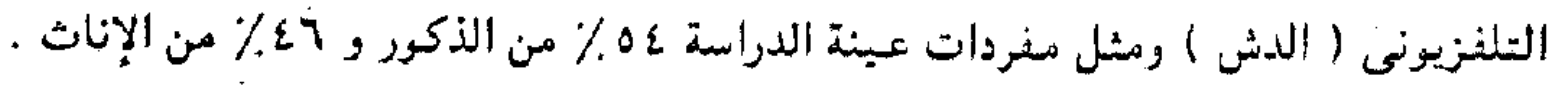

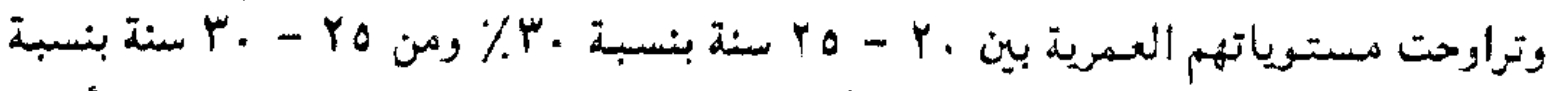

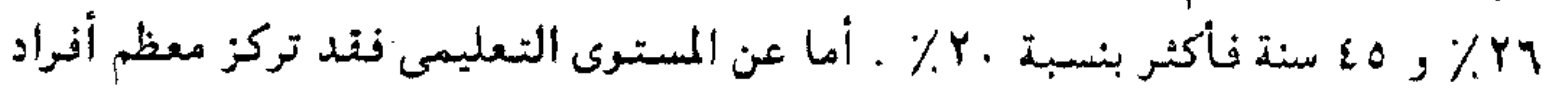

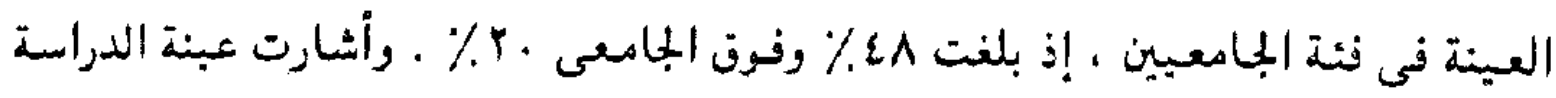

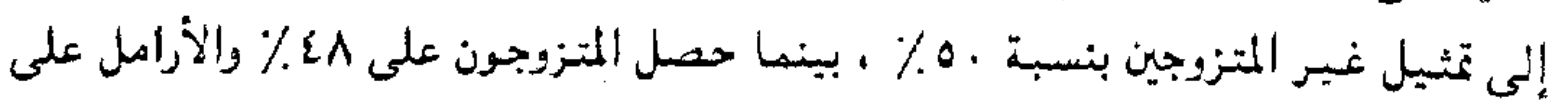




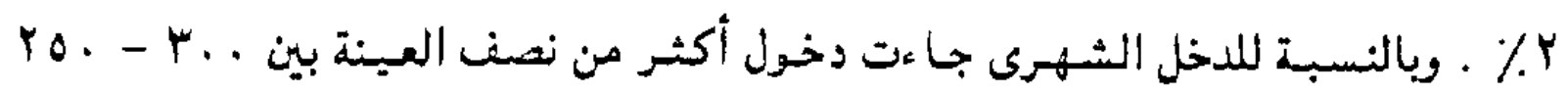

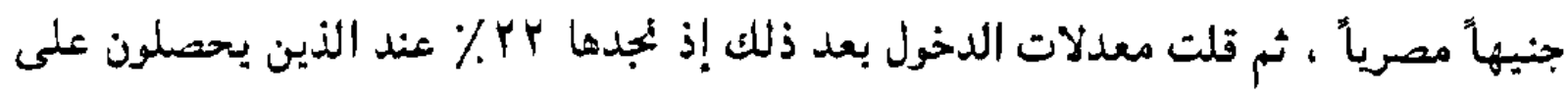
. Y . - ro.

وقد استخدم الباحث المنهج التاريخى فى دراسته للبث التلغزيرنى المباشر وتأثيره فى البه

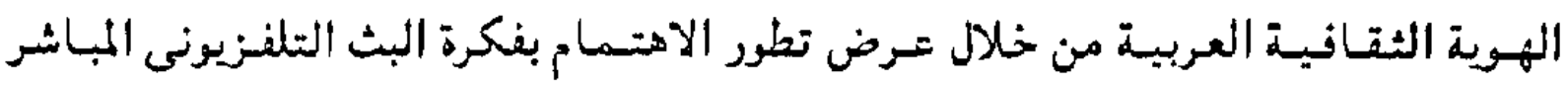

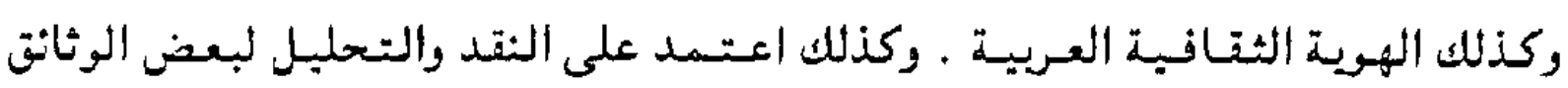

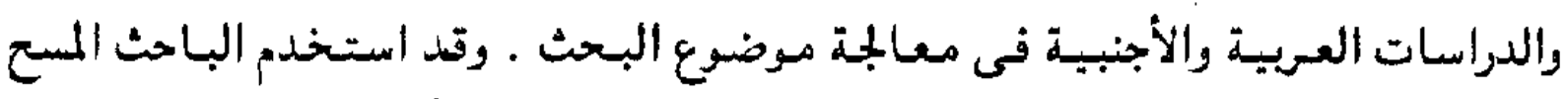

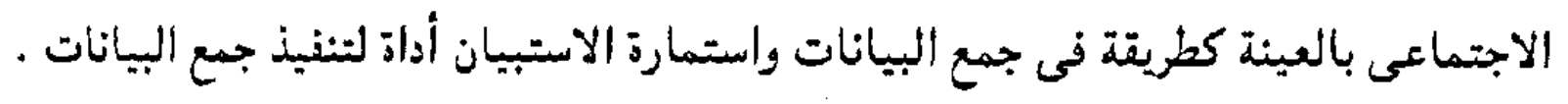
وأخيراً تأتى هذه الدراسة فى خسـة محاور أساسية ، تشكل في هجموعتها الإطار

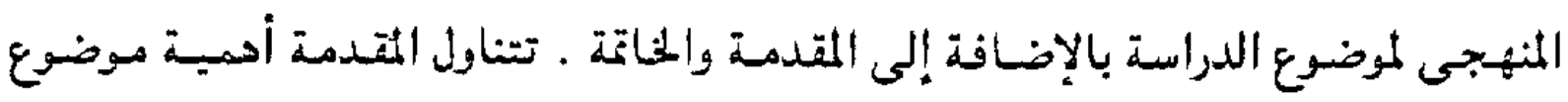

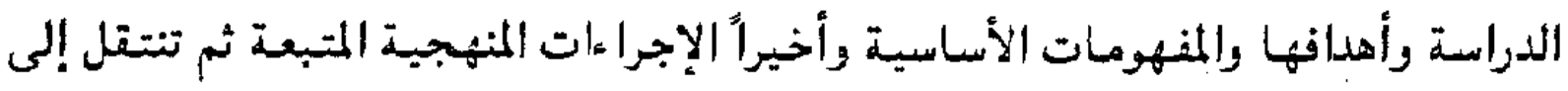

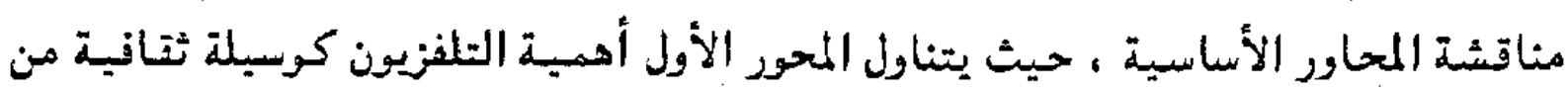

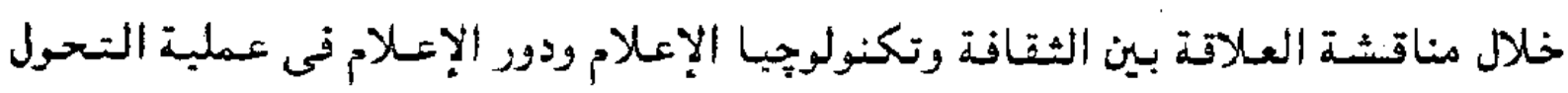

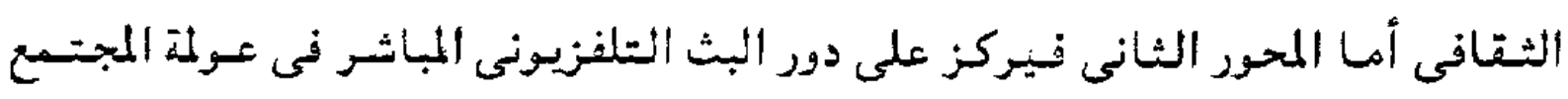

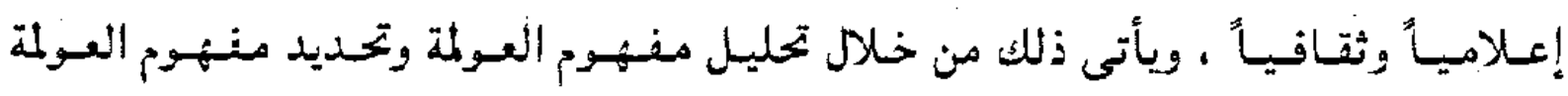

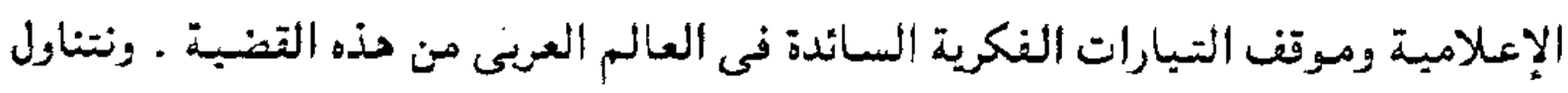

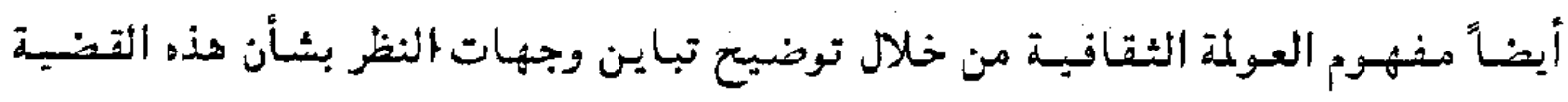

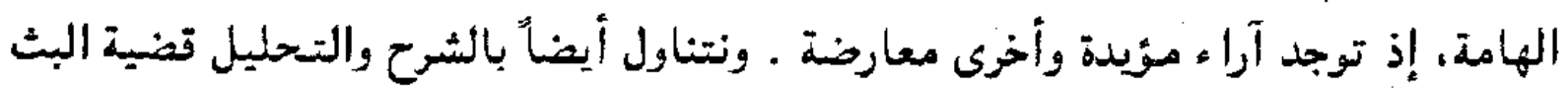

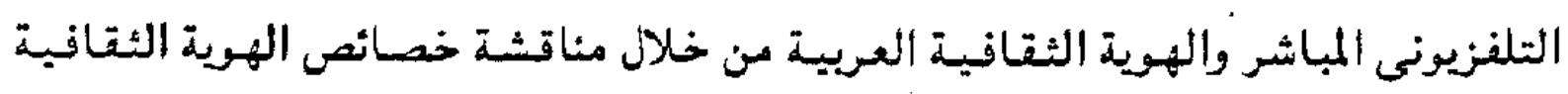

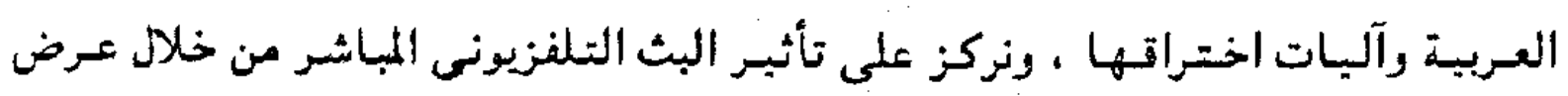
تحليلات ونتانج بعض الدراسات العريبة والأجنبية .

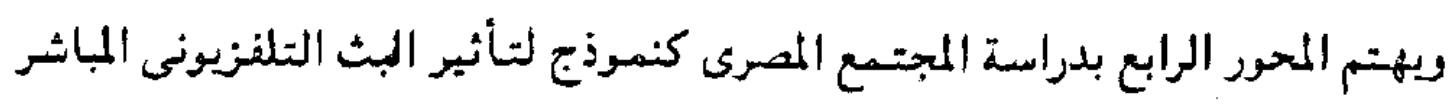

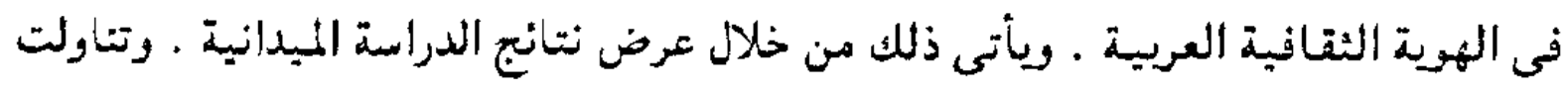

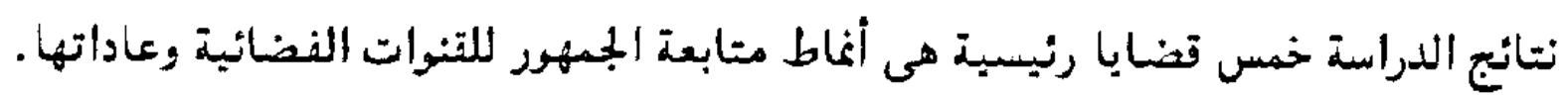

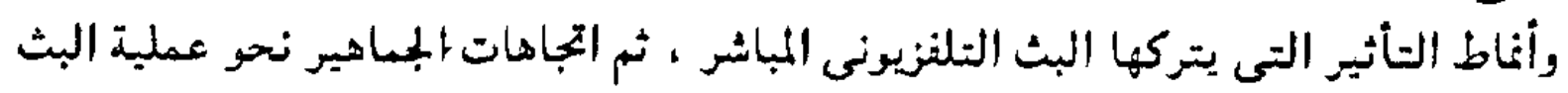

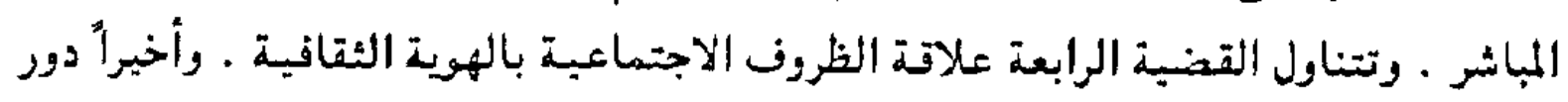


ويتناول المحور المامس الأخير الجهود المبذولة للحفاظ على الهوية الثقافية العريية ،

إز حاولت بعض الدول إقامة استراتيسجيات إعلامية تؤكد هويتها الثقافية ، وفى النهاية نختم الدراسة بمناقشة مجموعـة من النتائج النظرية والتطبيقية التى خلصت إليها الدراسة

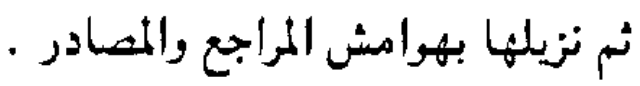

\section{أولا ، التلفزيون وسيللح ثقافية :}

يلدور نقاش كثير حول الدور المتميز للتكنولوجيـا فى فهم أنفسنا ، فضلاً عن فهم تاريخنا المشترك ، فالتكنولوجيا بصفة عامة ثقافية منذ البداية ، فهى تعبير عن وجهات

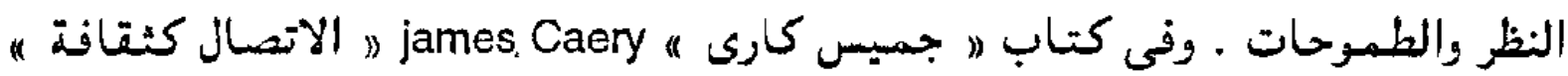

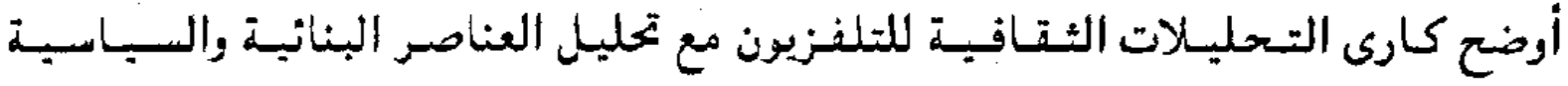
والصناعية في تكوين الوسيلة ، ووصف التلفزيون باعتباره وسيلة تنهض على مقومات

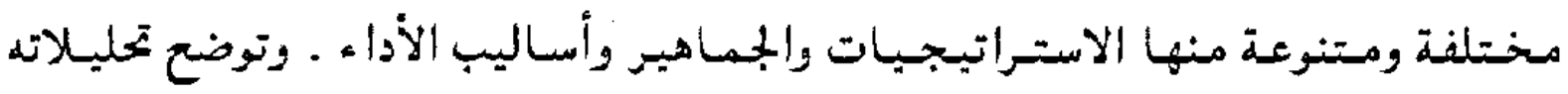

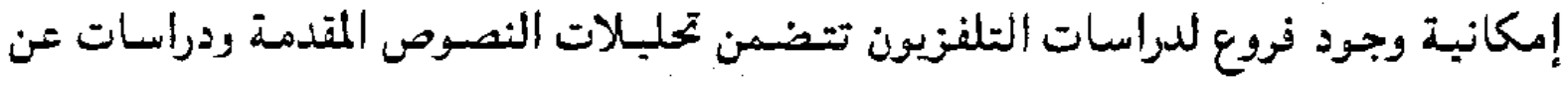
الإنتاج وأبحاث التأثير وأخرى متعلقد بموضوعات تقنية ـ ويأتى ذلك ضمن دراسة سياسة أنتداخل الثقافى (ir)

وقدم " ايريك ميكلس Eric Michales " مناقشة مطولة عن العـلاقة بِين الثتافة

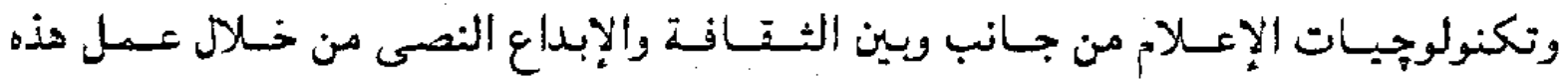

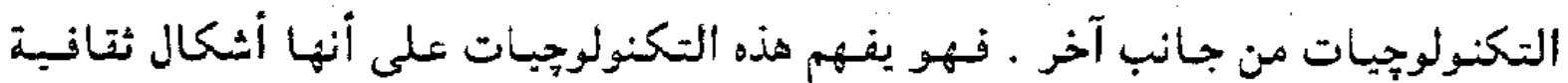

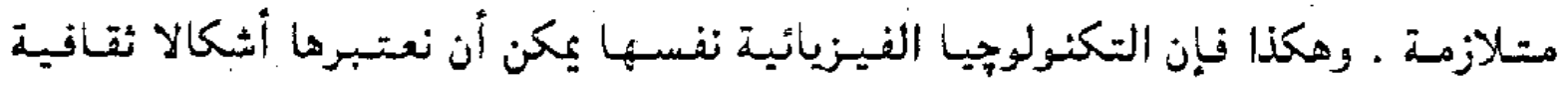

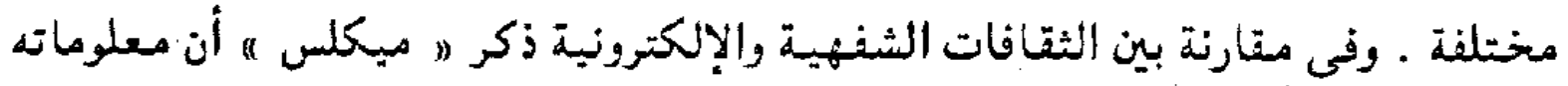

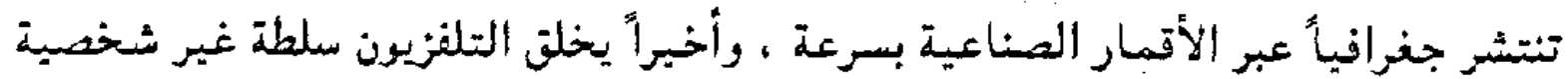
(1) ومعرفة أصلية

وكان من نتائج الثورة فى مجال تكنولوحيا الإعلام أن روجت لمفهوم القرية العالمية

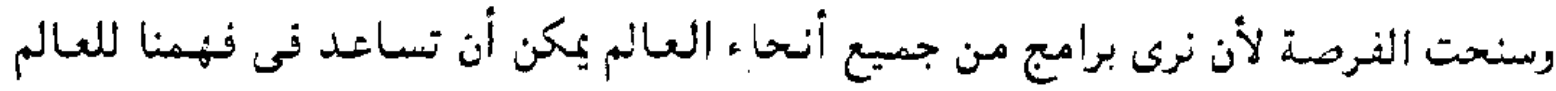

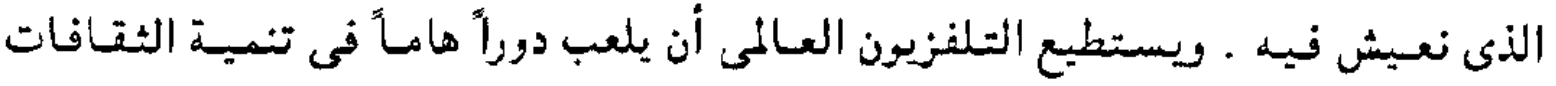

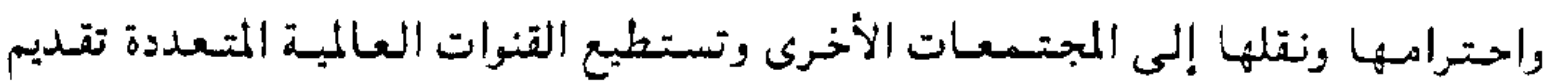

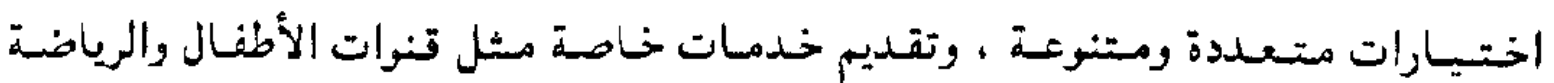

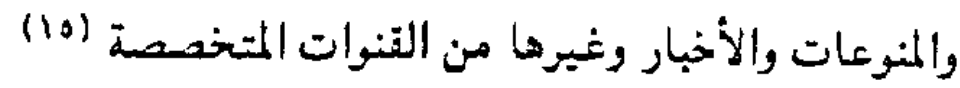


وكان من ينتأتج الثورة فى مجال تكنولوجيا الإعلام أن روجت لمفهوم القرية العالمية

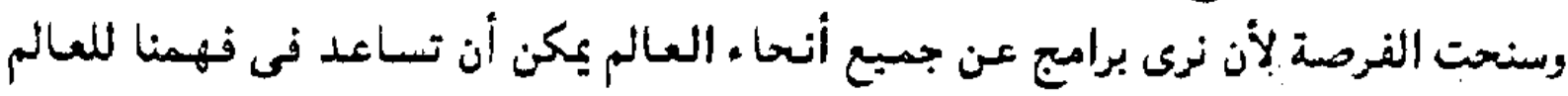

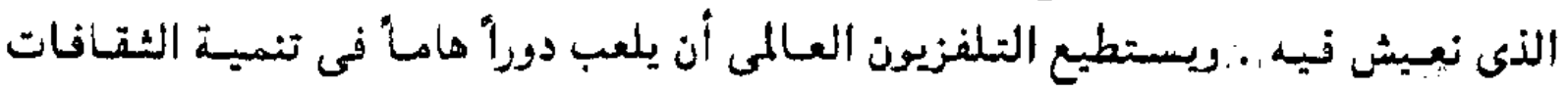

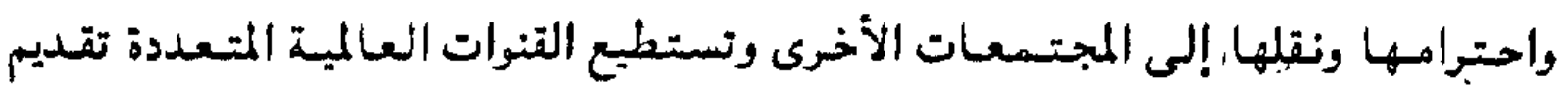

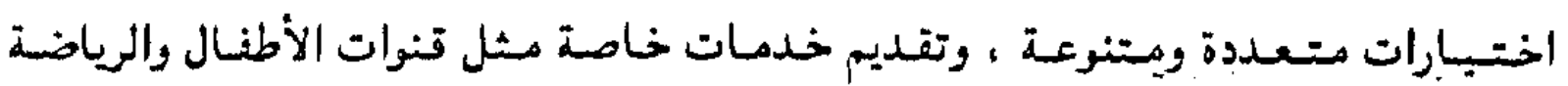

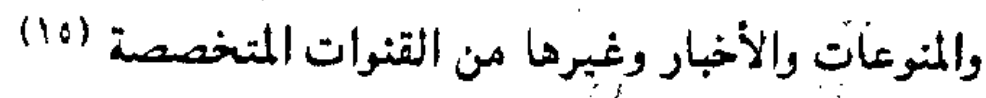

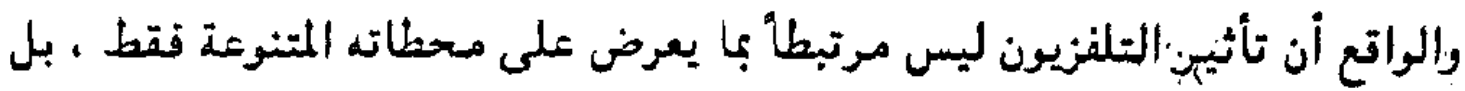

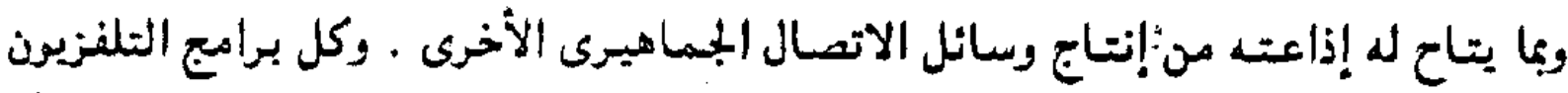

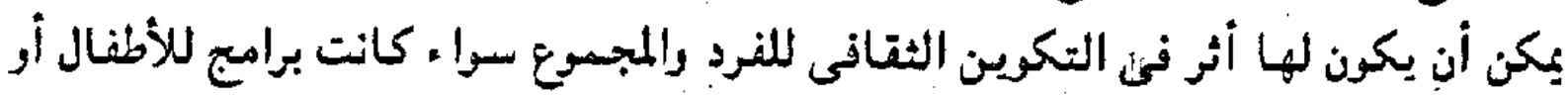

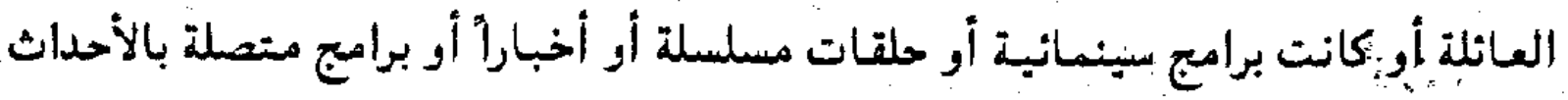

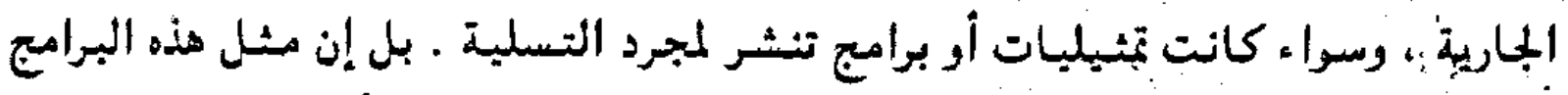

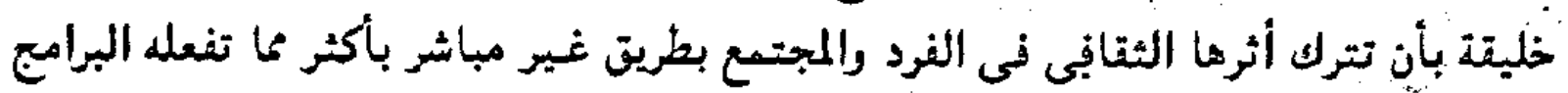

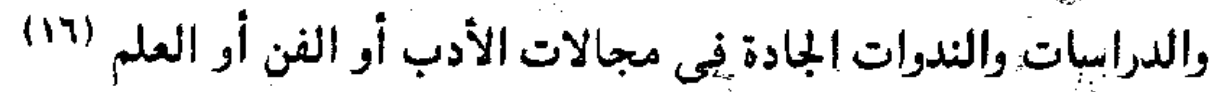

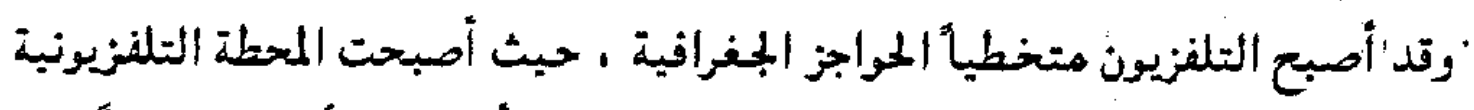

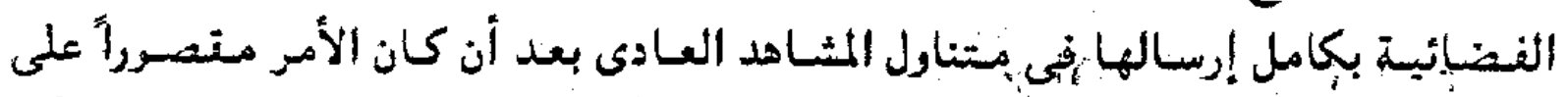

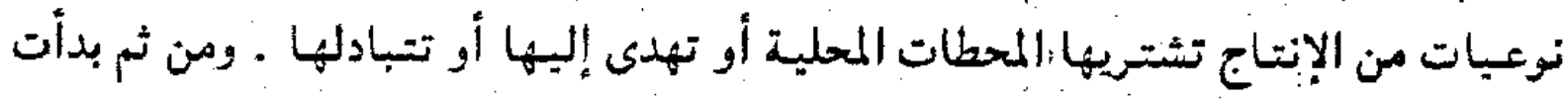

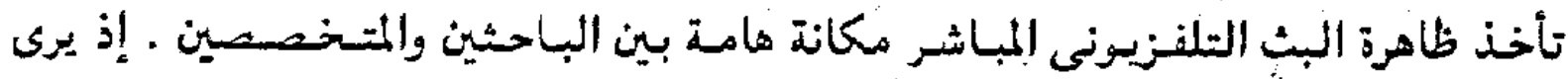

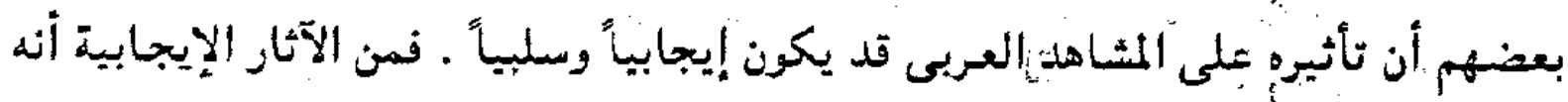

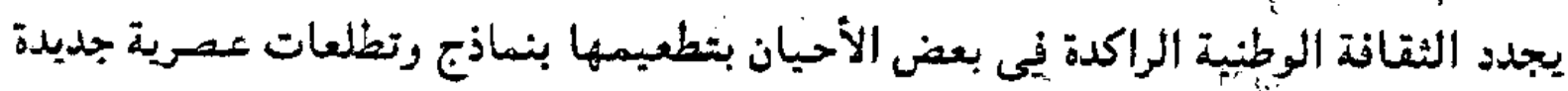

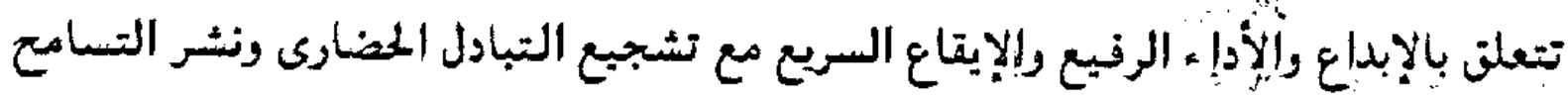

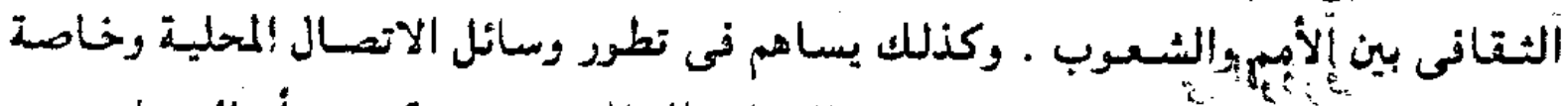

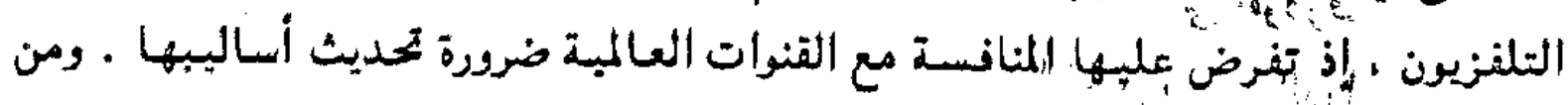

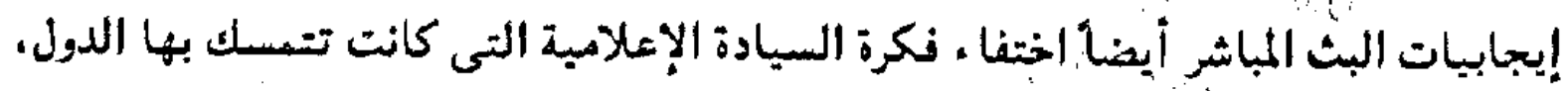
الأمر الذى سوف يثير. قلتى المبكومات الاستبدادية والثظم العنصرية .

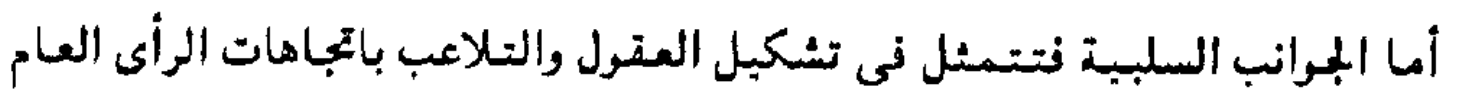

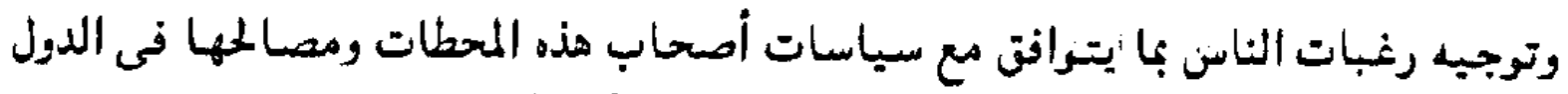

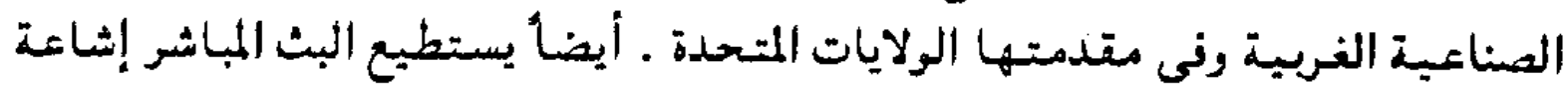

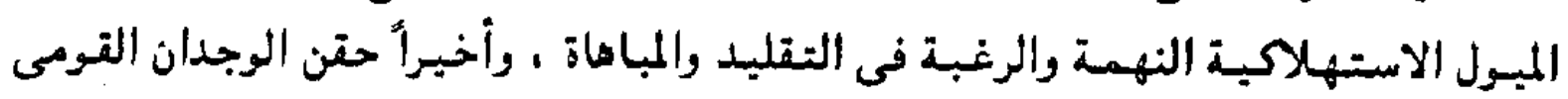




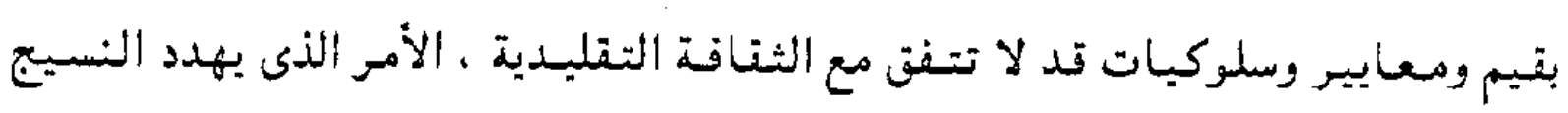
(IV) الاجتماعى

ويمكن القسول إن التليـــزيون - خـاصسة بعـد انتـشـار ظاهرة البث المبـاشـر وتزايد

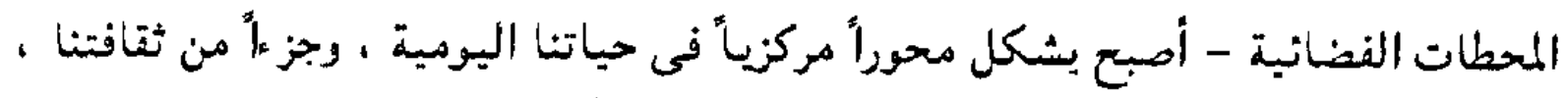

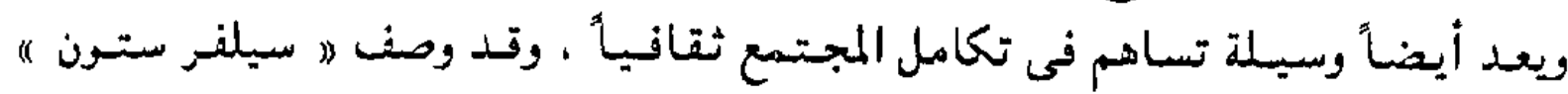
Silver stone

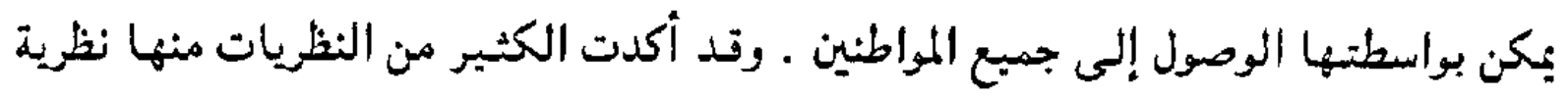

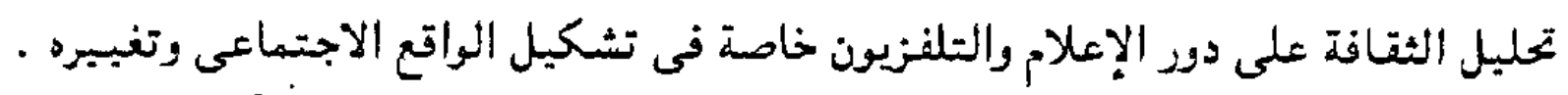

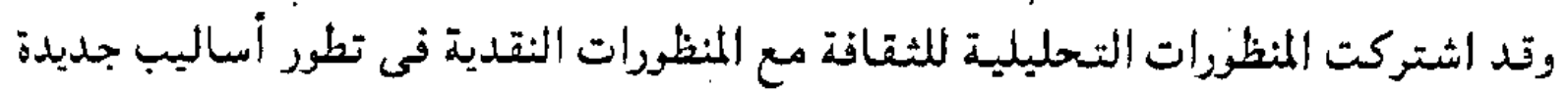

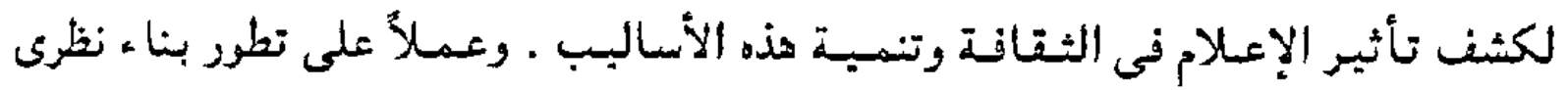
ومتكامل . وأكدا على أهمية الإعلام فى تشكيل وجهات نظر الناس عن أنفسهم وبيئاتهم

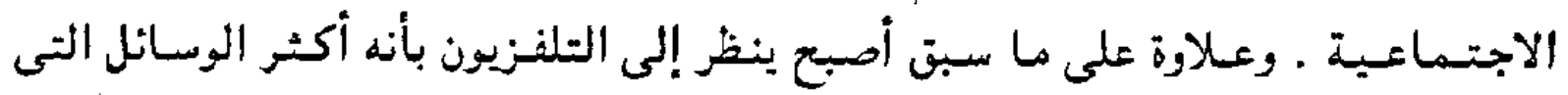

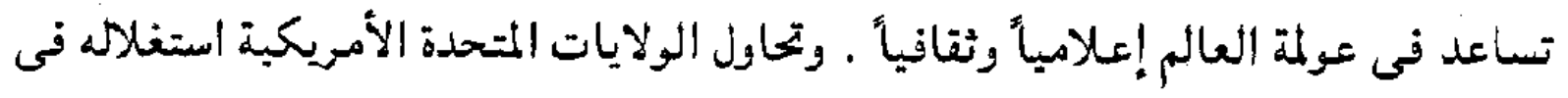
نشر ثقافتها وتعميمها مقابل طمس الثقافات الوطنية الأخرى (IA) .

\section{ثانيأ : البث الثلمزيونى المباشر وعولمة المجتميع :}

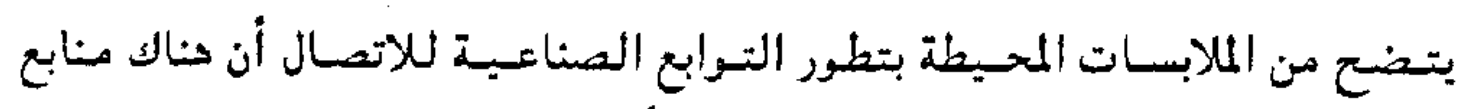

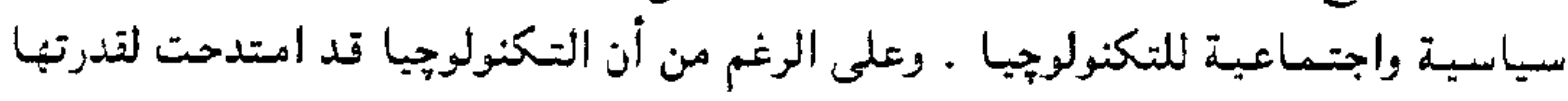

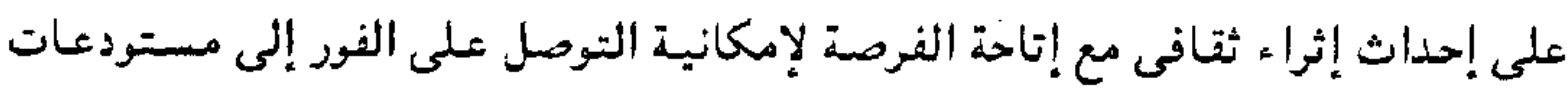

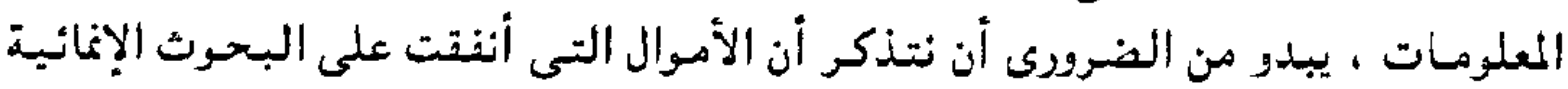

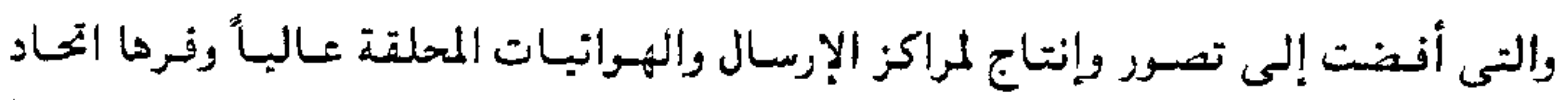

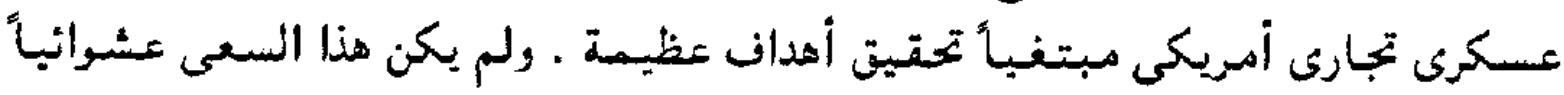

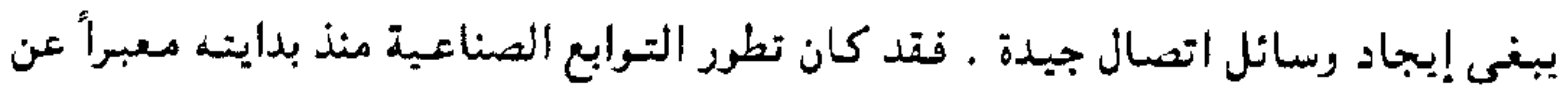

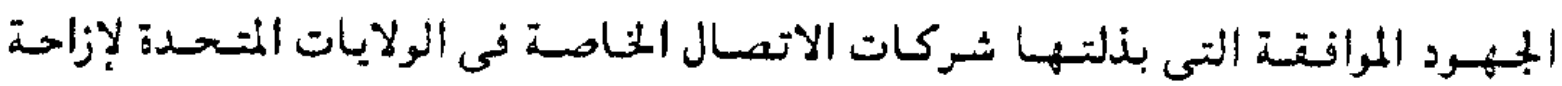

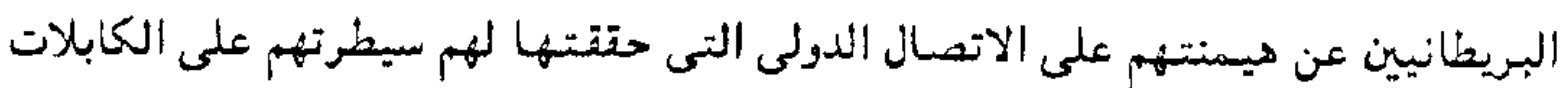

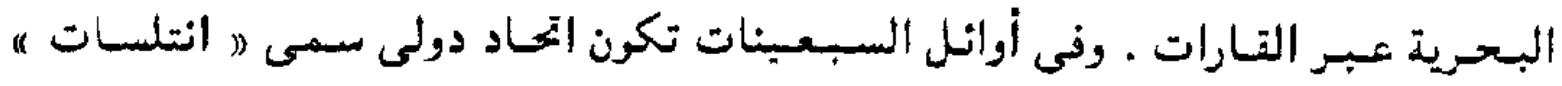
Intelesat

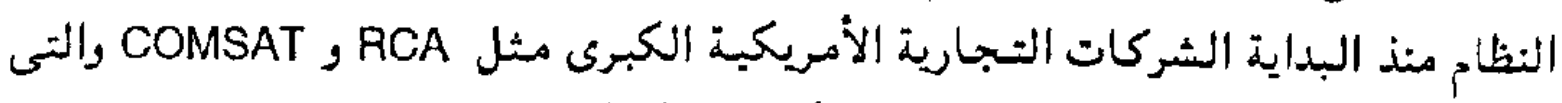

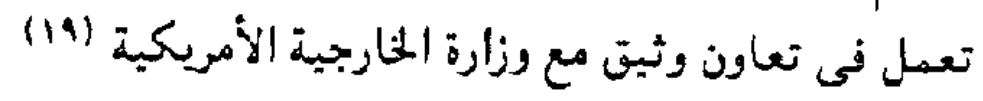




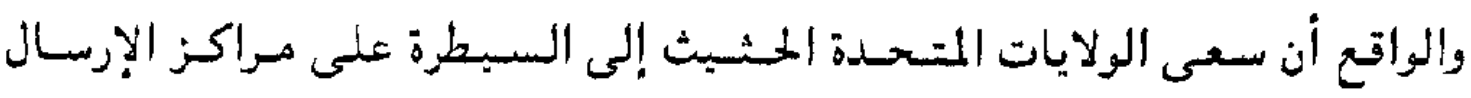

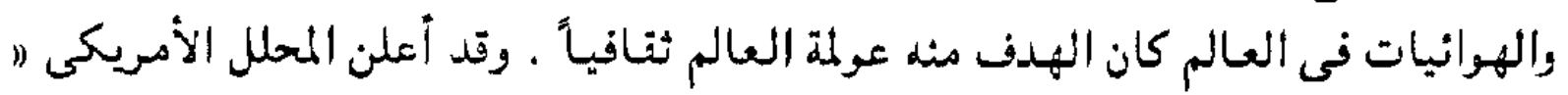

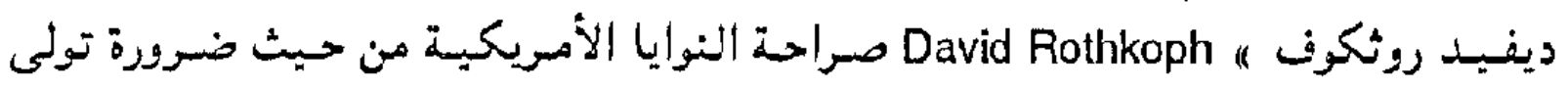

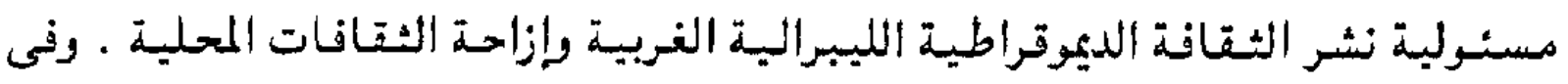

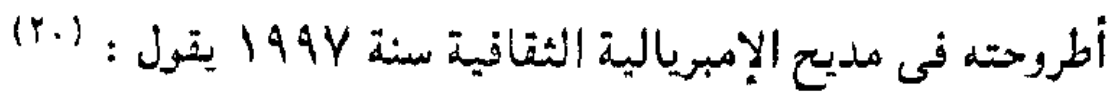

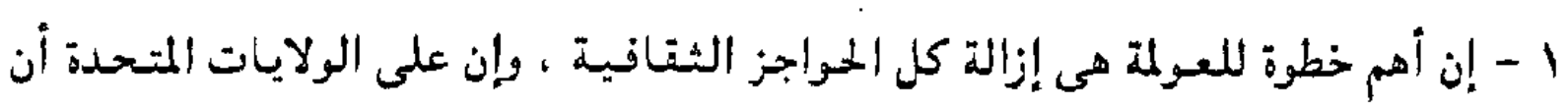

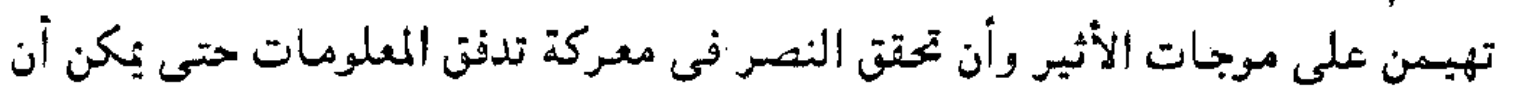
تكون لها السيطرة والهيمنة في الوقت الحاضر والمستقبل .

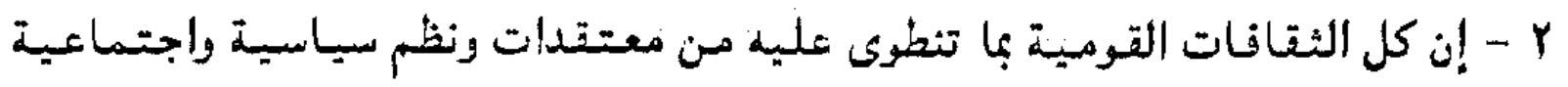

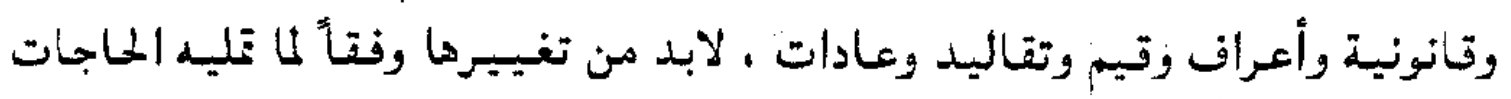

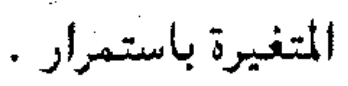

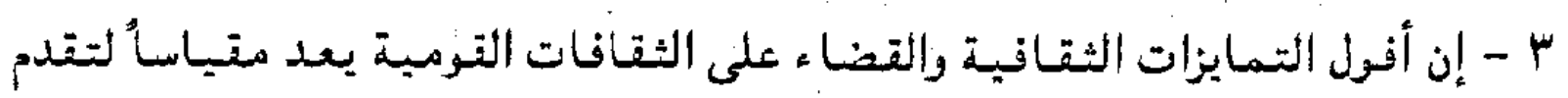

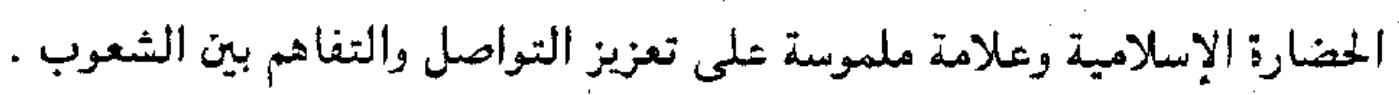

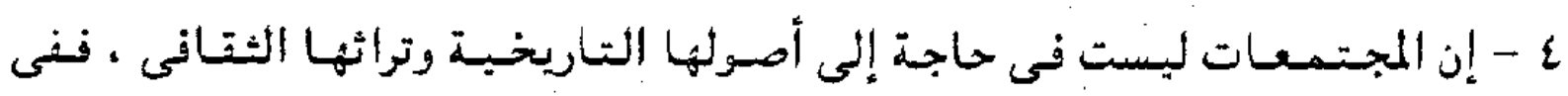

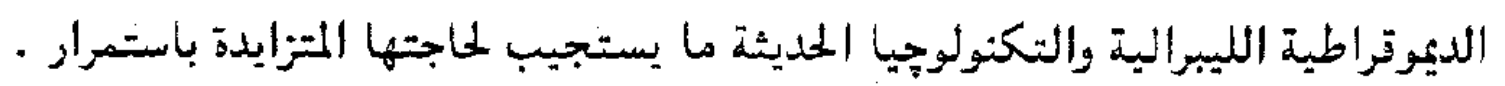

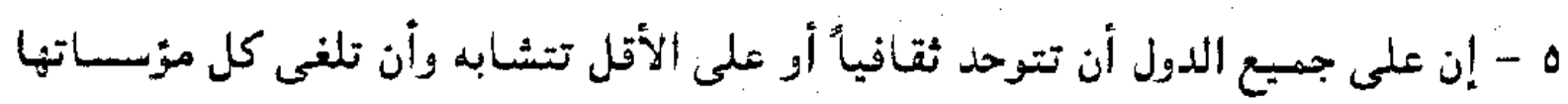

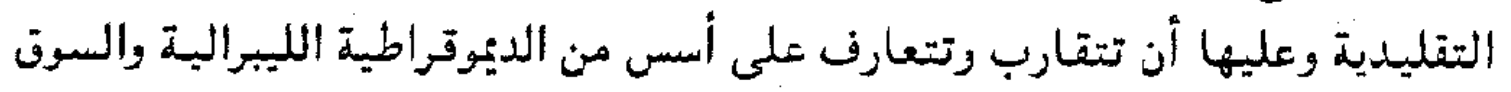
العالمية.

7 - وفى النهاية يدعو إلى أن تكون اللغة الإنجليزية هى لغة الثقافة العالية الجديدة ولغة التخاطب على الكوكب الأرضى .

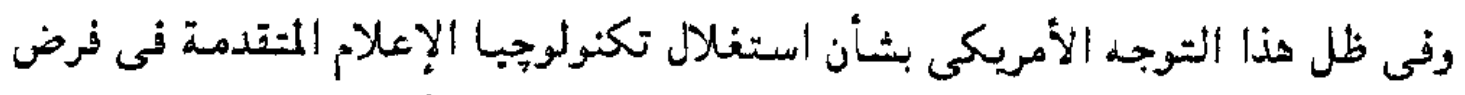

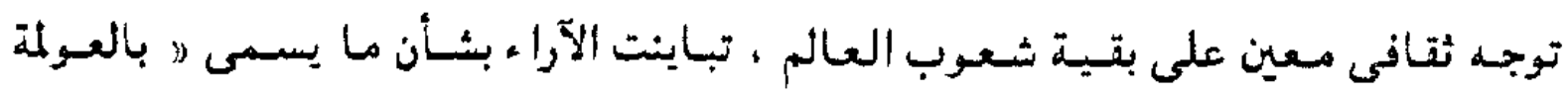

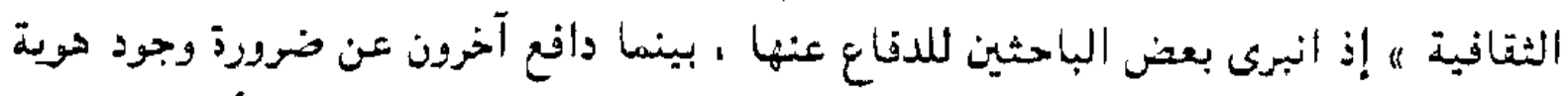

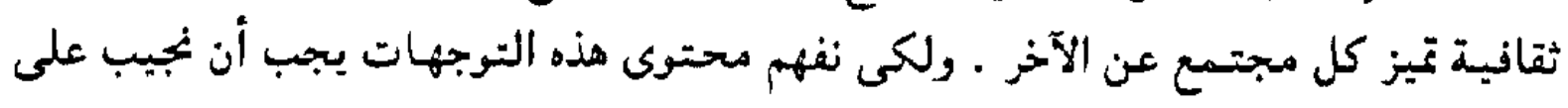

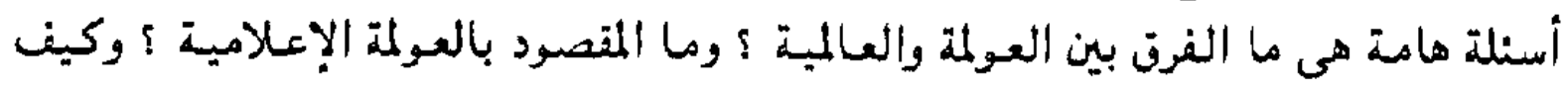

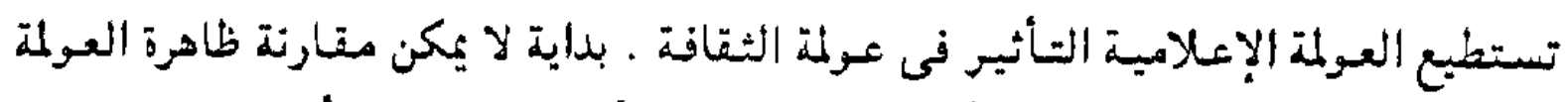

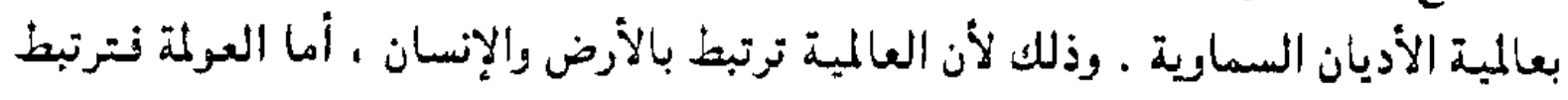




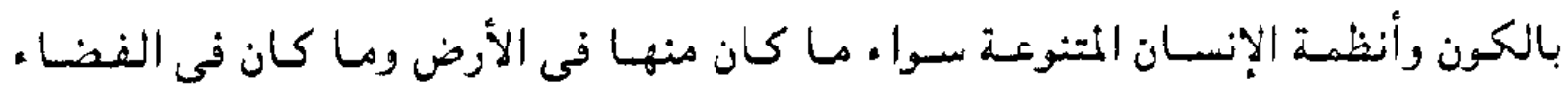

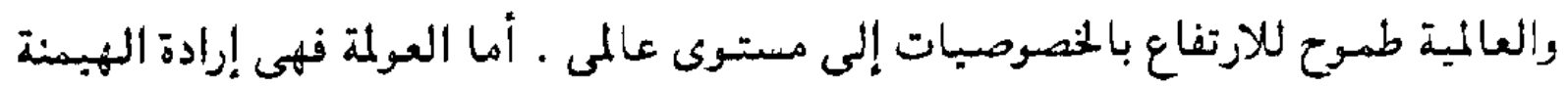

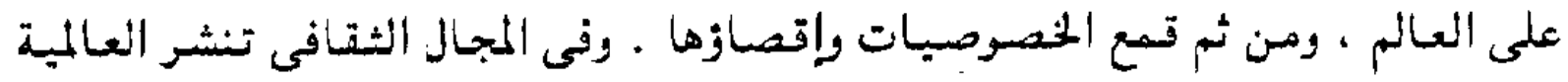

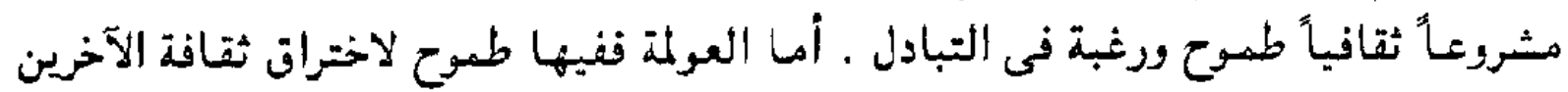

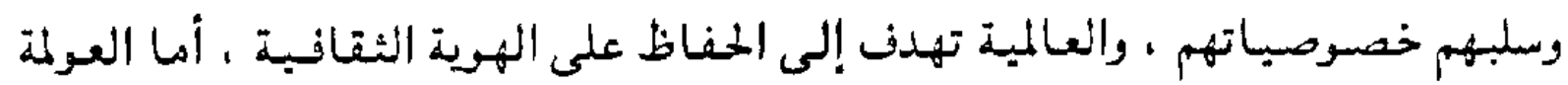

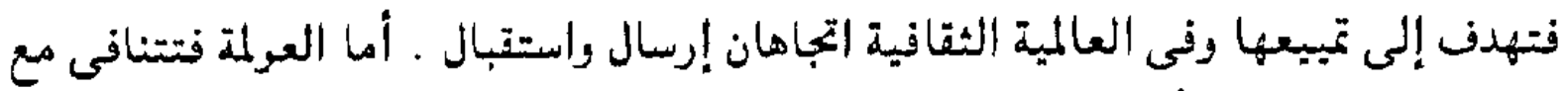

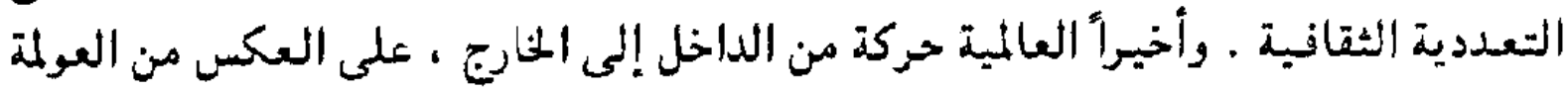

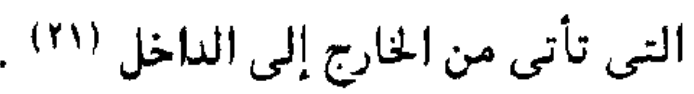

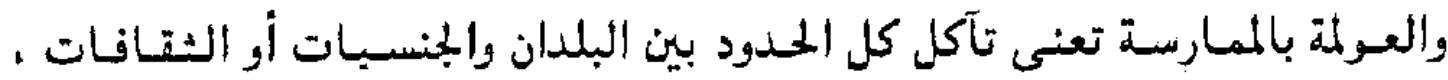

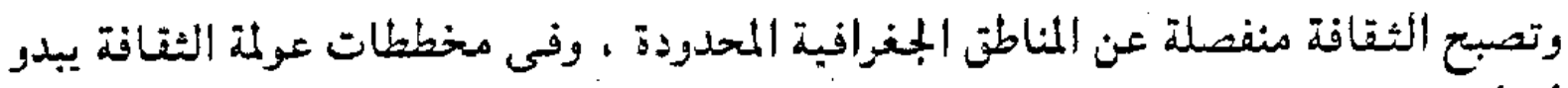

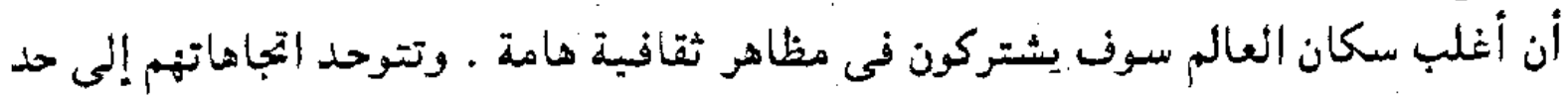

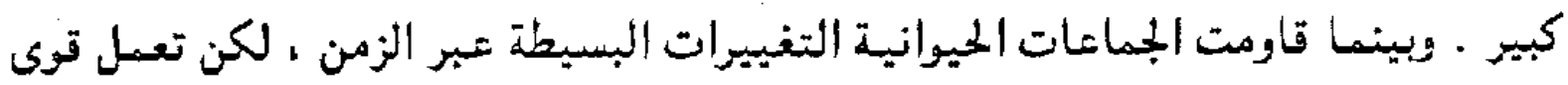

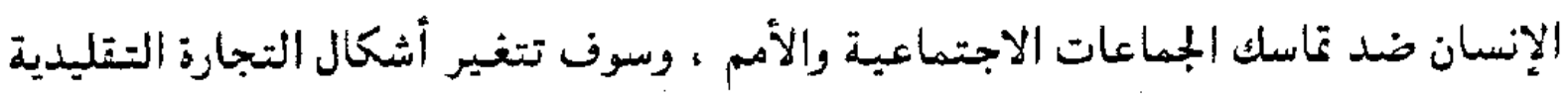

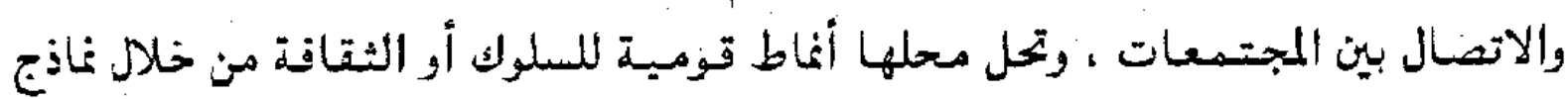

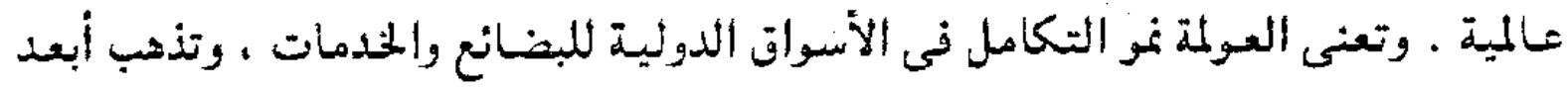

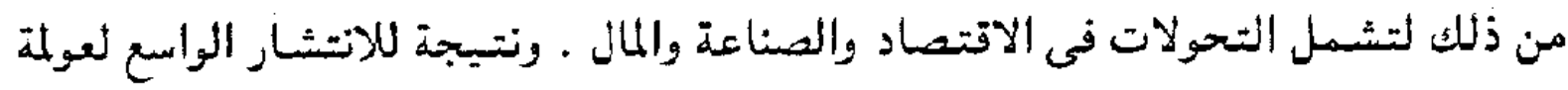

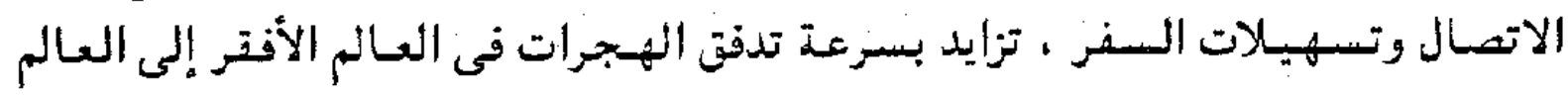

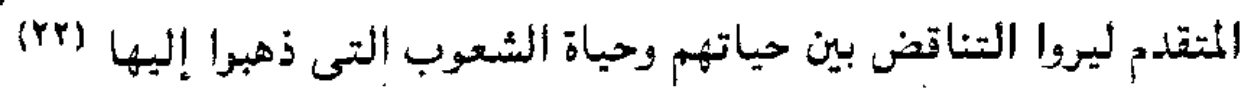

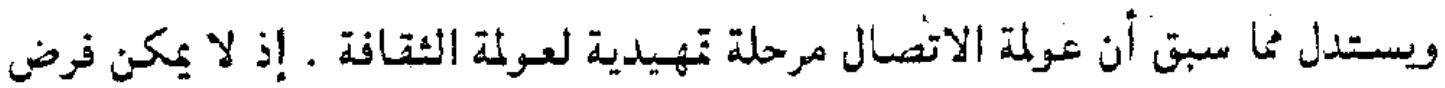

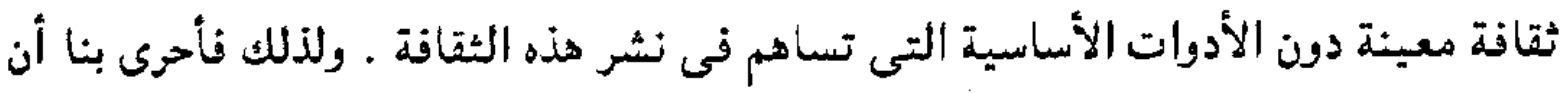

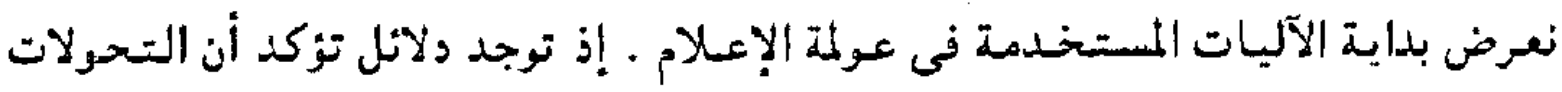

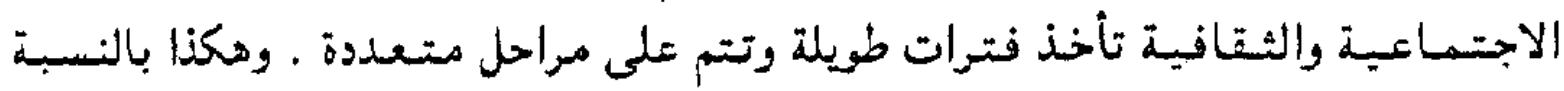

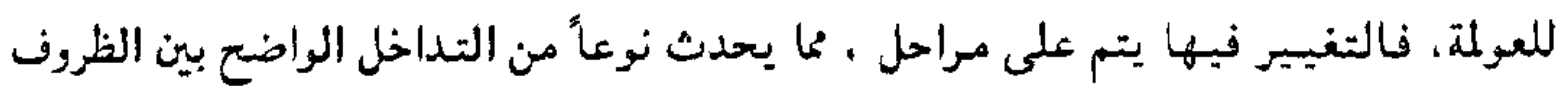

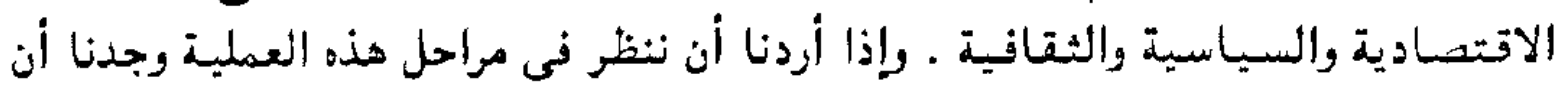

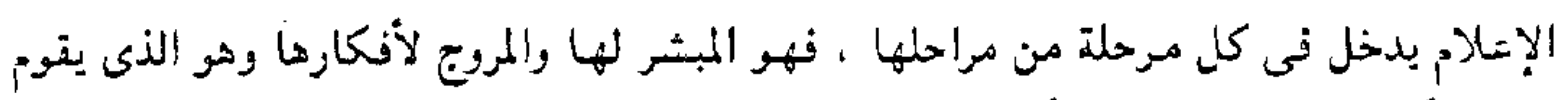

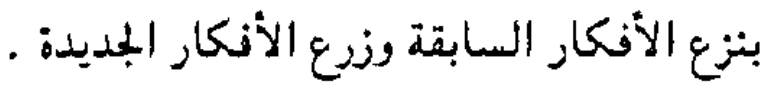

\section{العولة الإعلاعيلة Media Globalization}

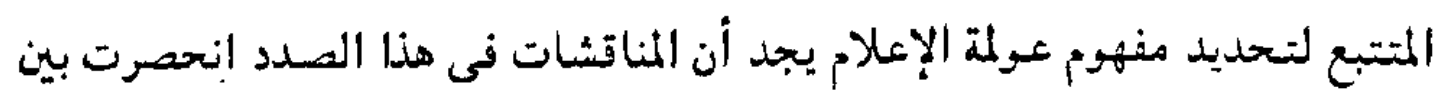

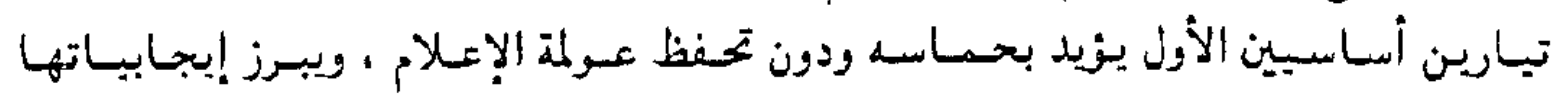


باعتبارها تدعم مبدأ التدفق الحر للمعلومات وحق الاتصال ، وتوفر للجمههور فرصا غيـ

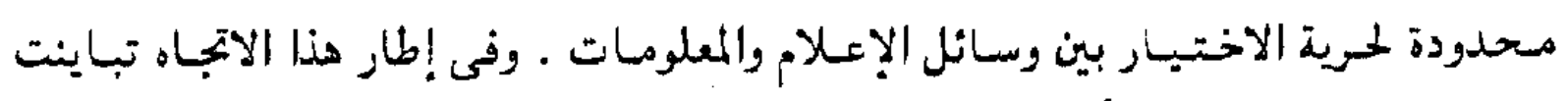

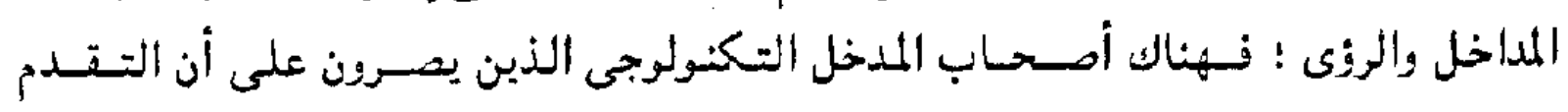

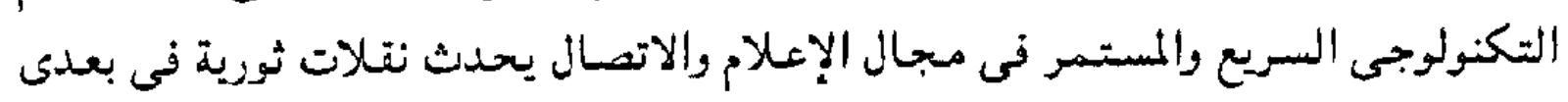

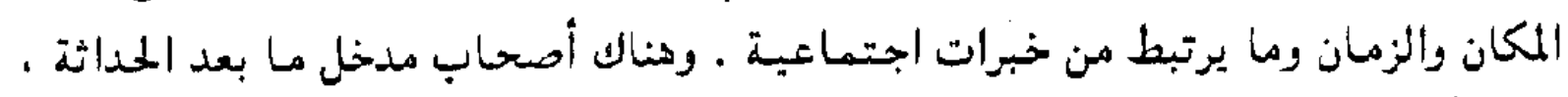

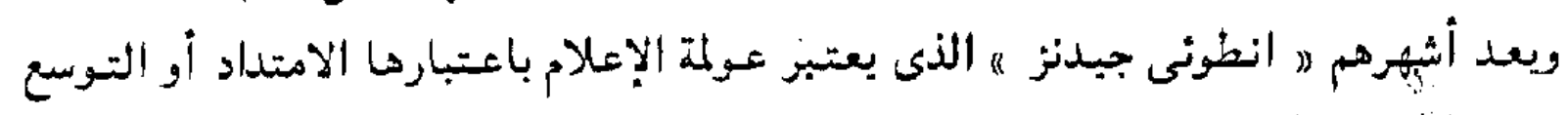

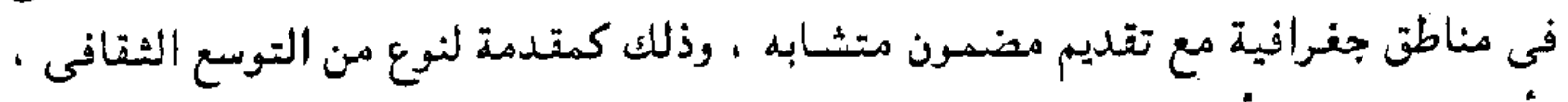

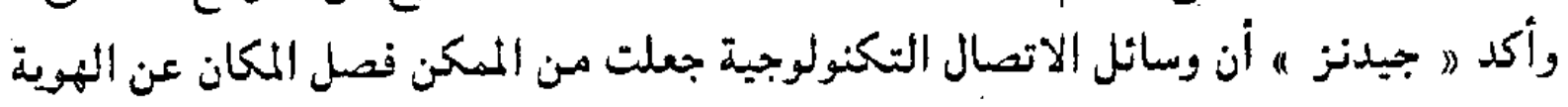

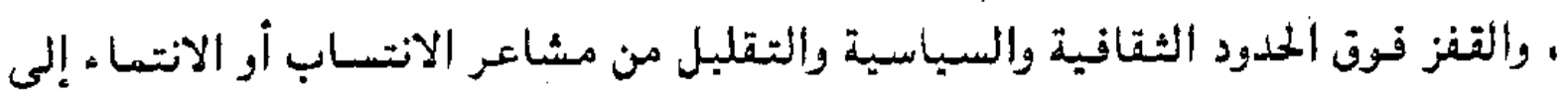

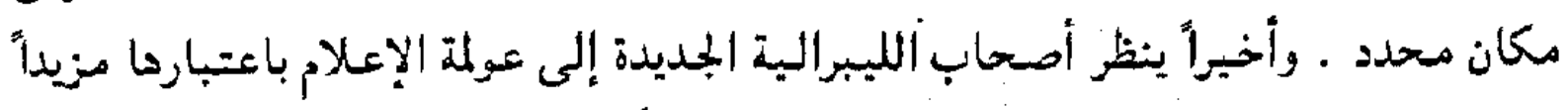

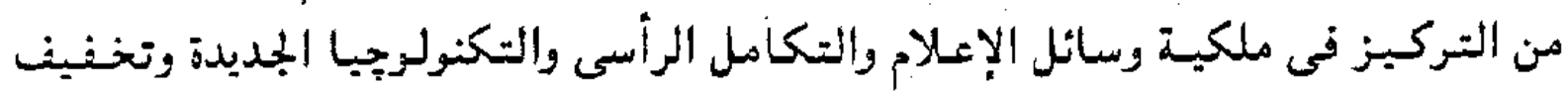
القيود (rr)

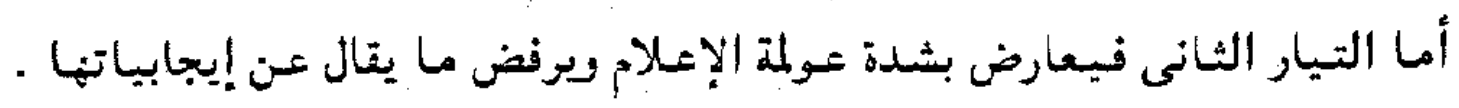

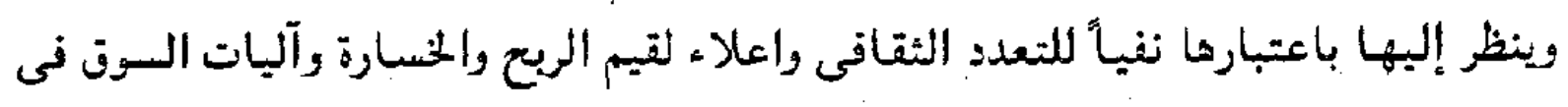

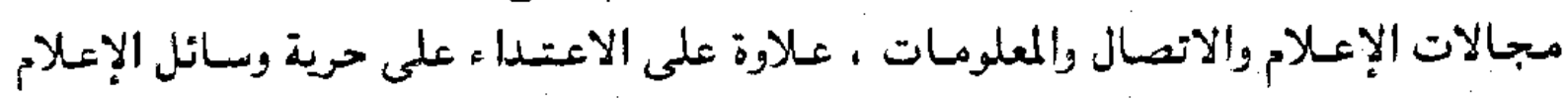

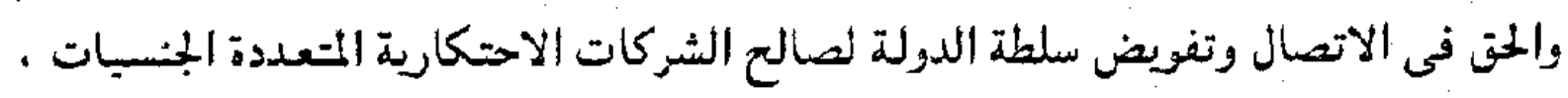

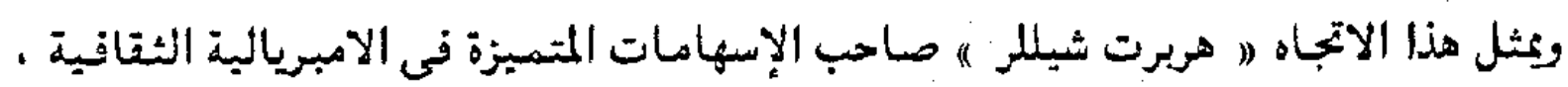

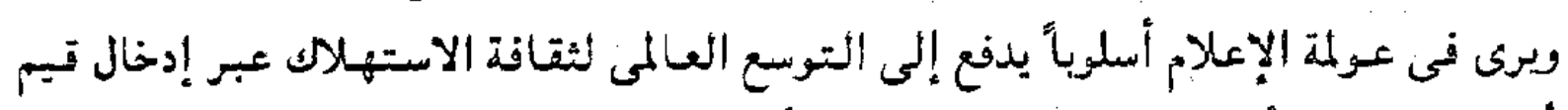

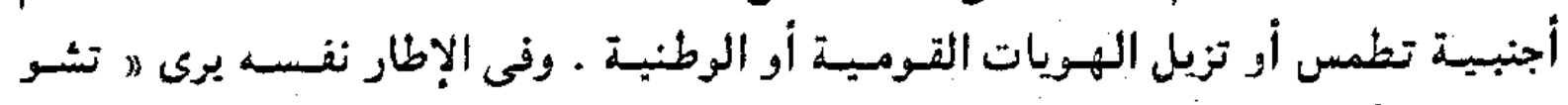

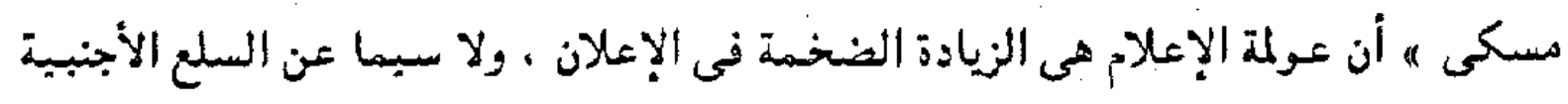

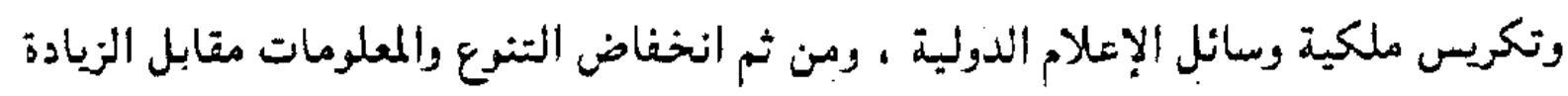

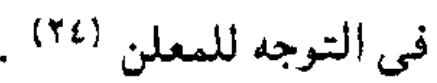

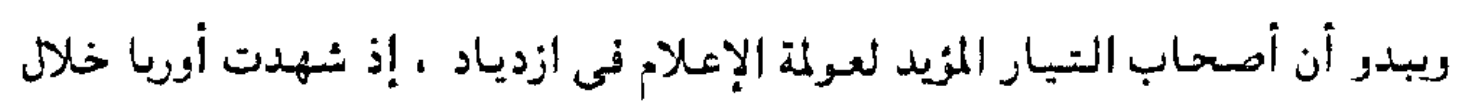

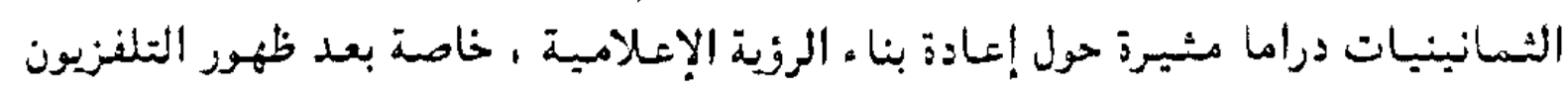

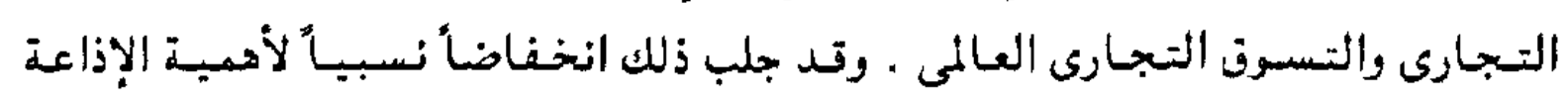

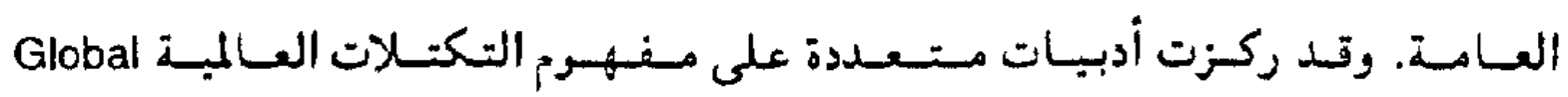
Conglomerates

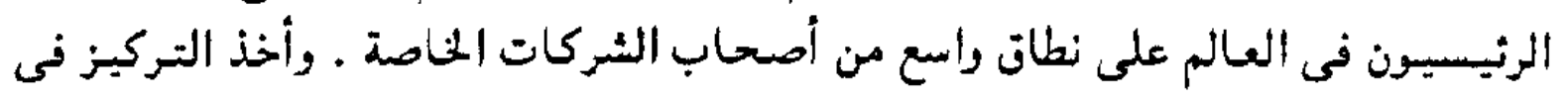




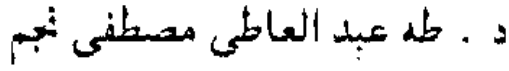

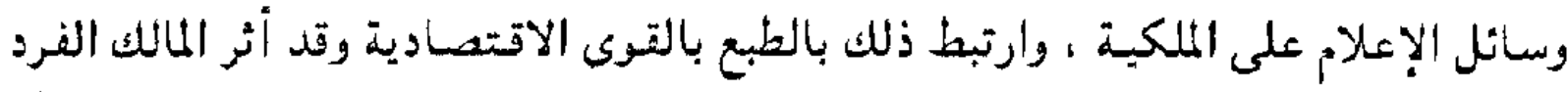

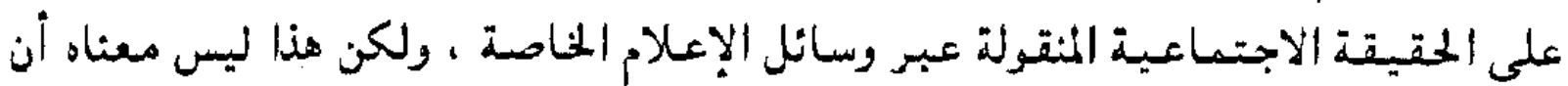

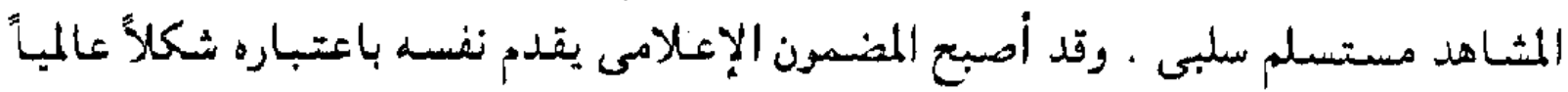

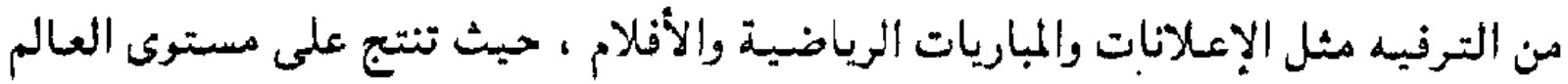

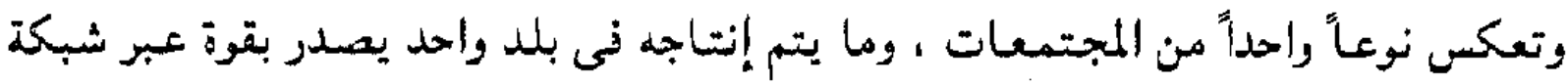

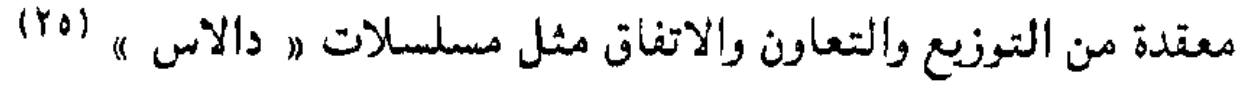

وكما حدث بالنسبة للإذاعة والتلفزيون توجد :لاتل تشبير إلى أن العولمة فى مجال

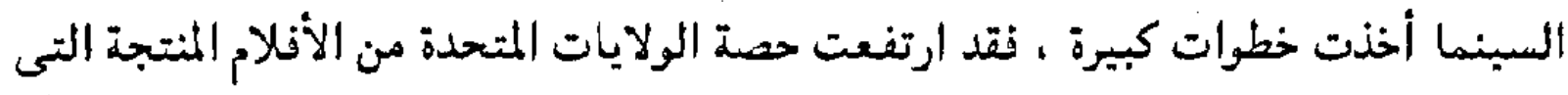

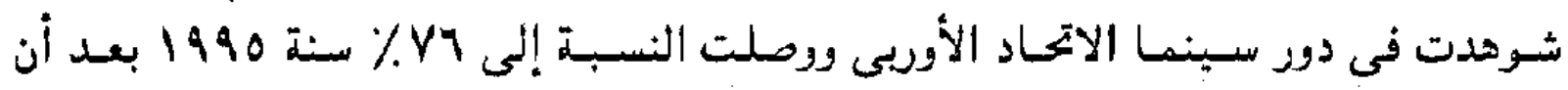

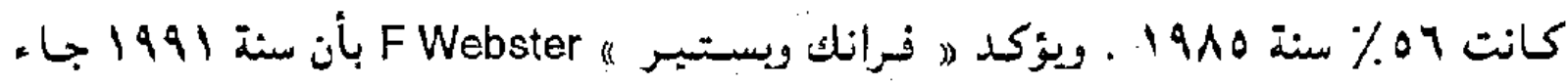

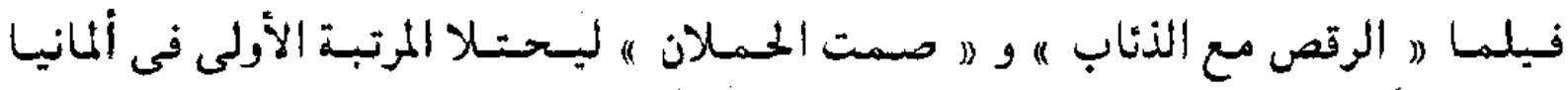

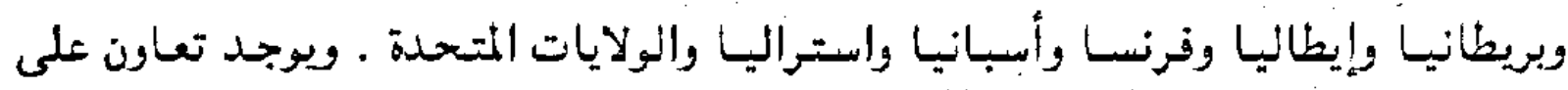

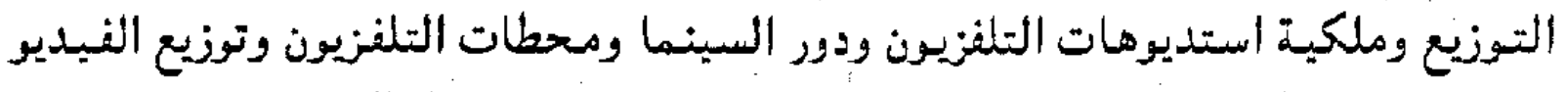

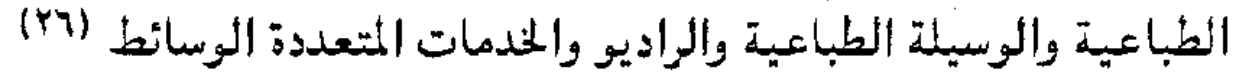

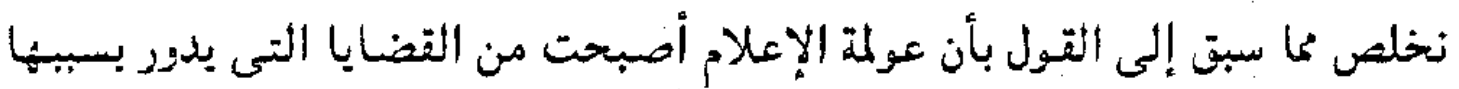

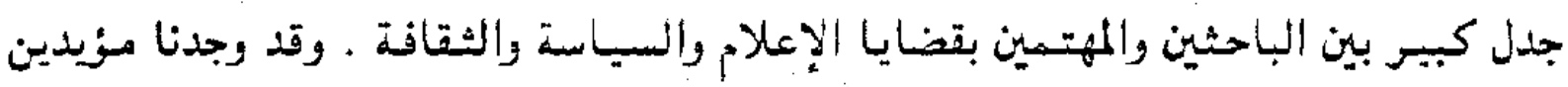

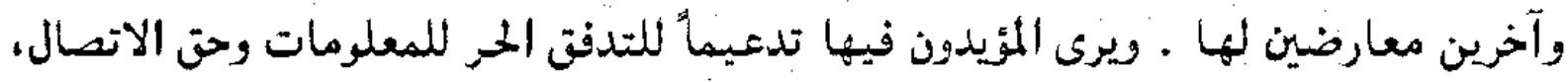

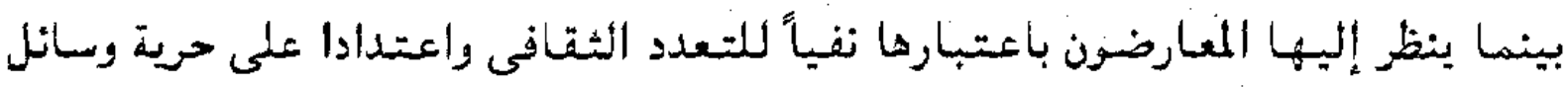

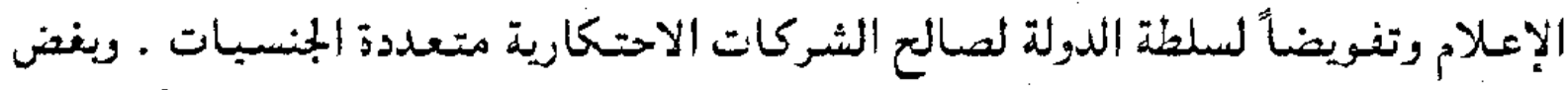

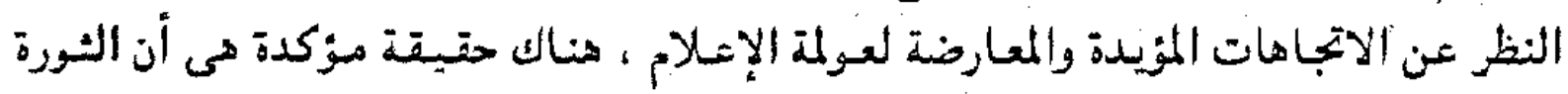

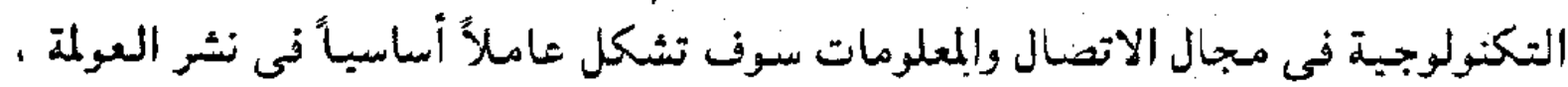

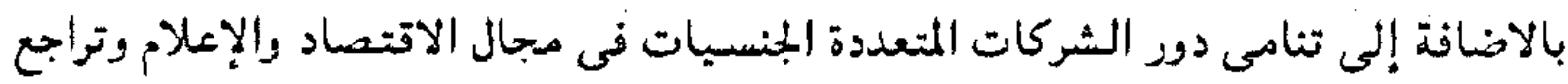

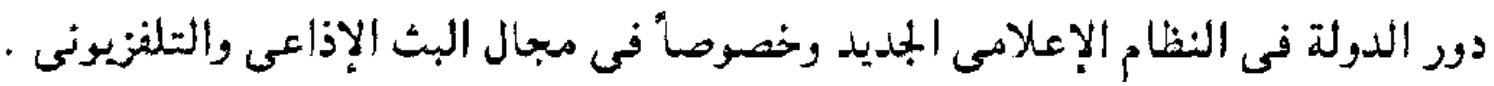

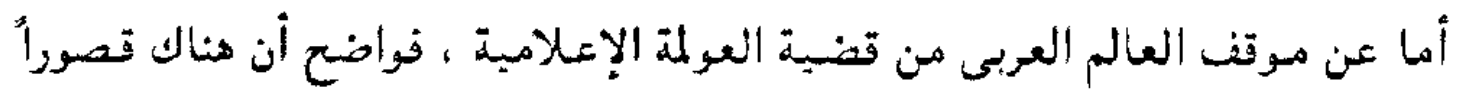

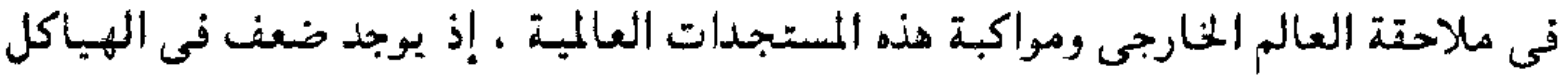

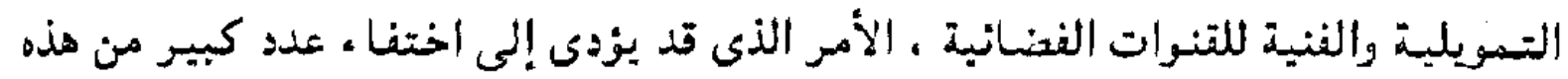

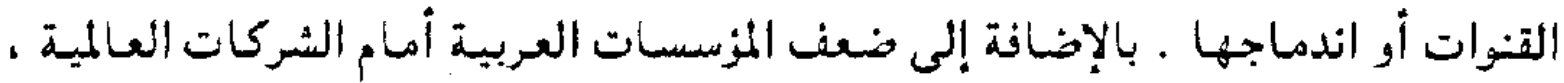

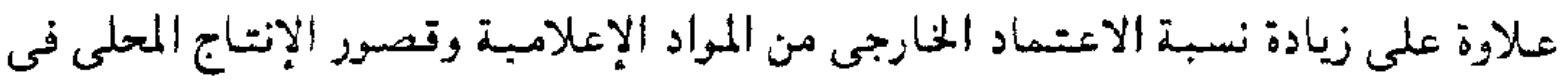




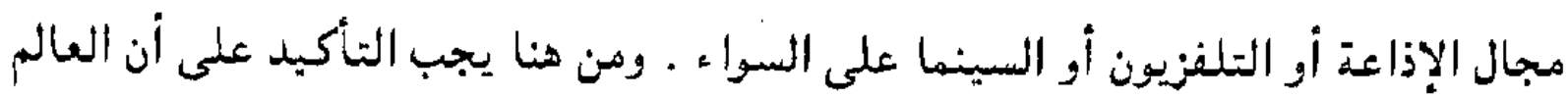

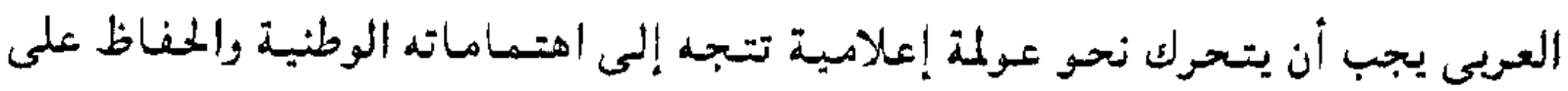

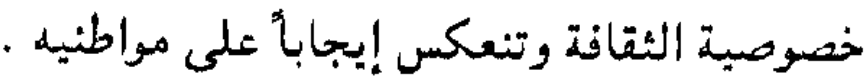

\section{: Cultural globalization العولمة الثقافية - ب}

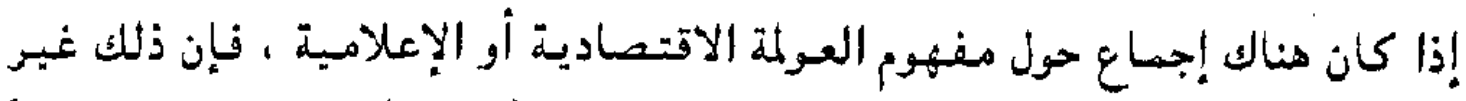

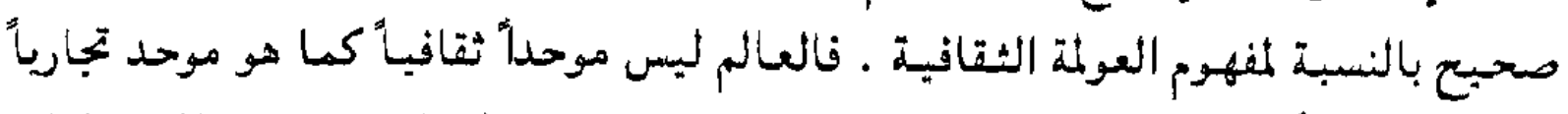

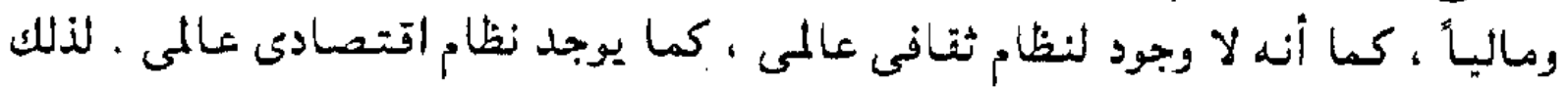

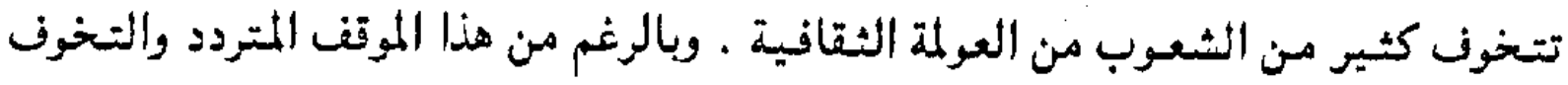

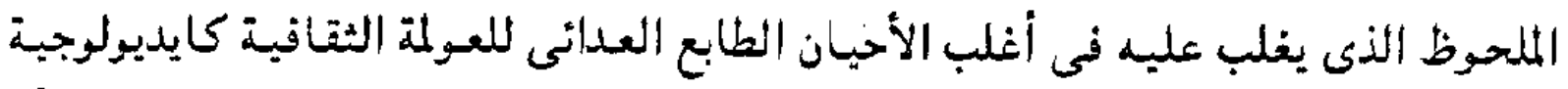

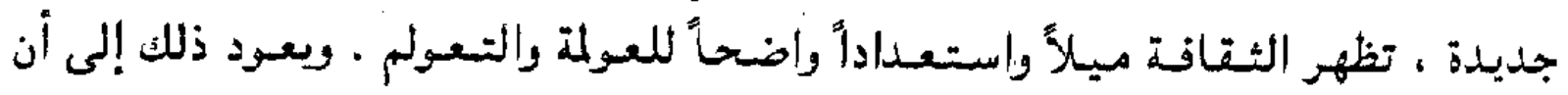

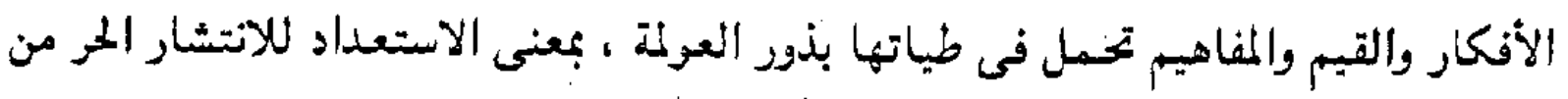

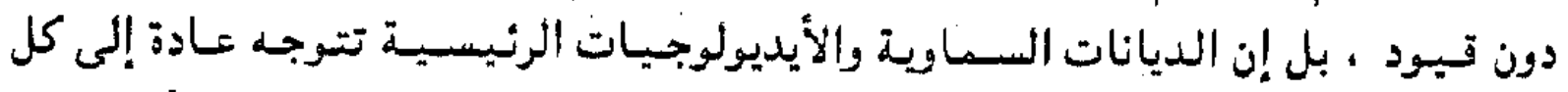

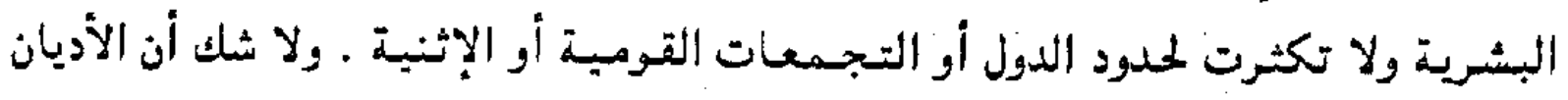

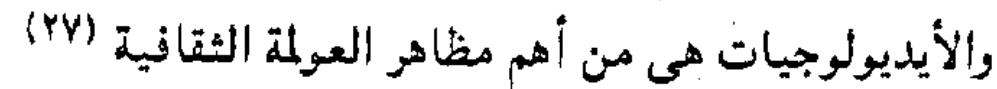

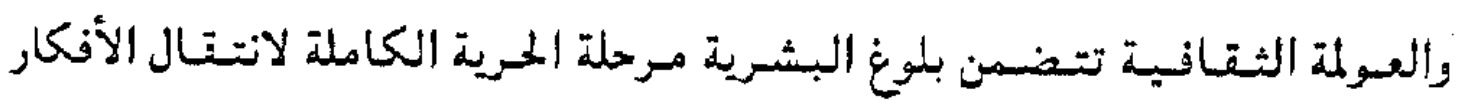

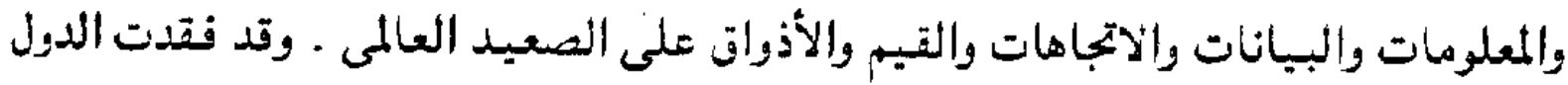

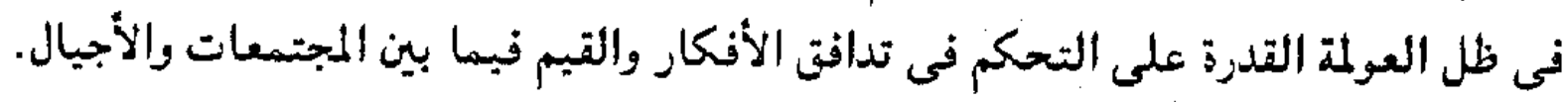

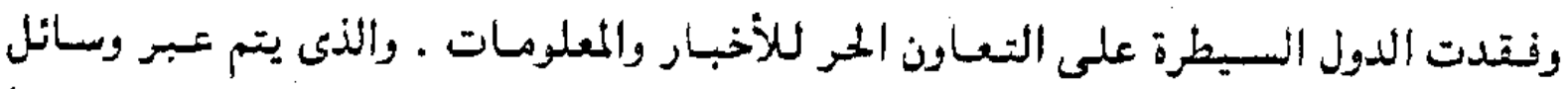

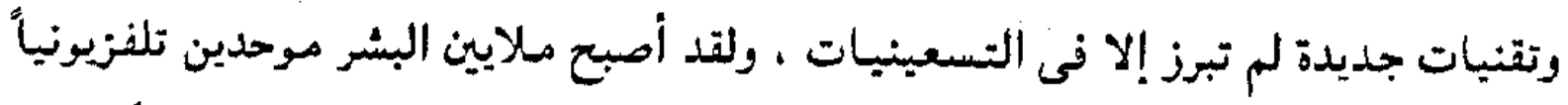

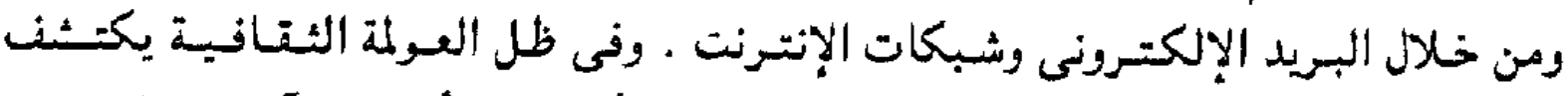

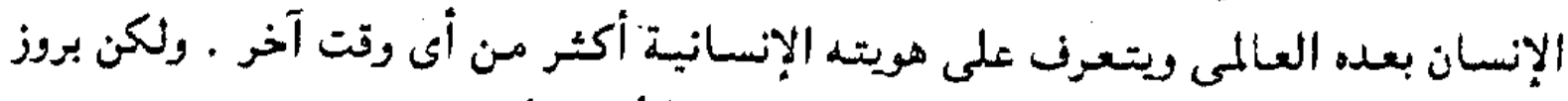

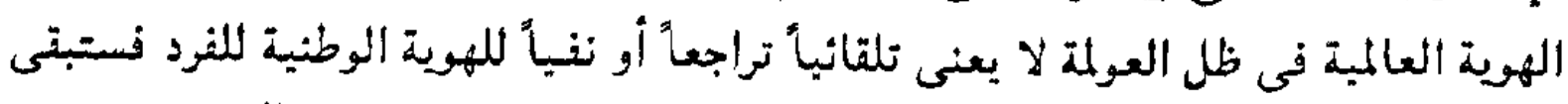

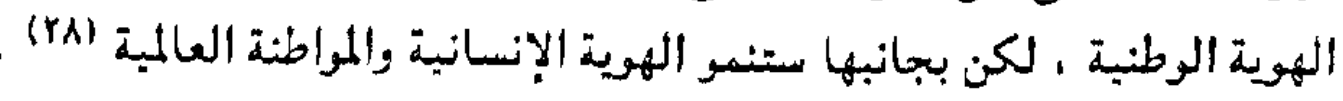

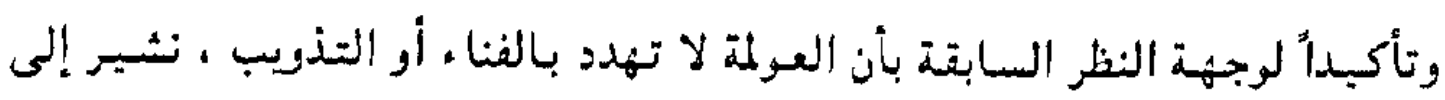

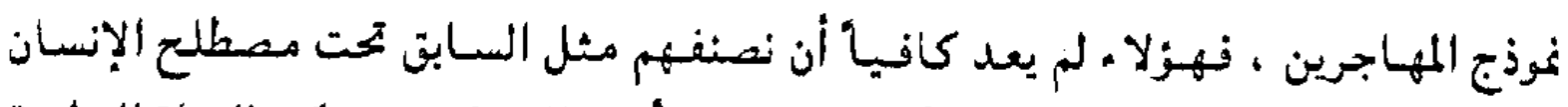

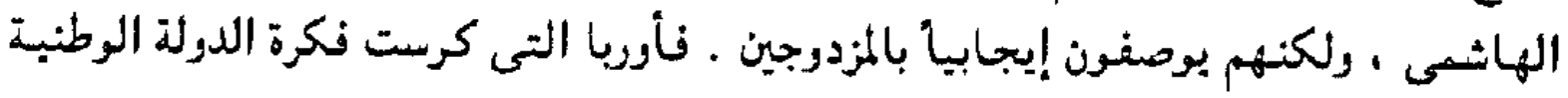

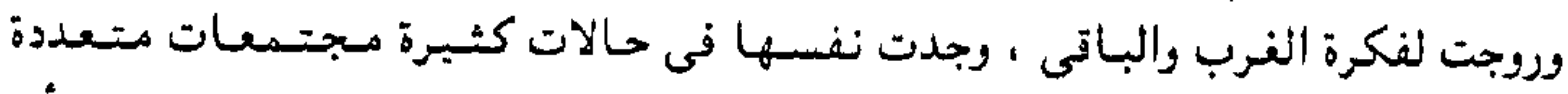

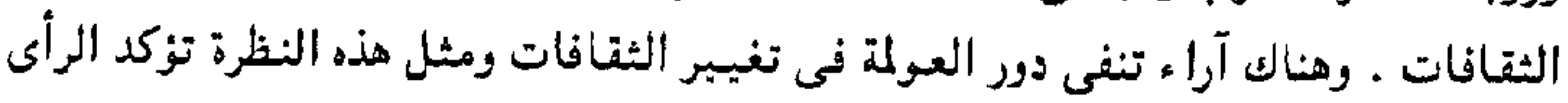




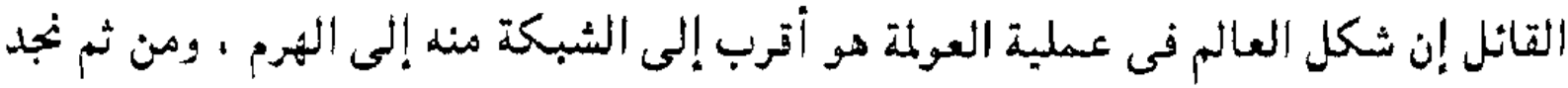

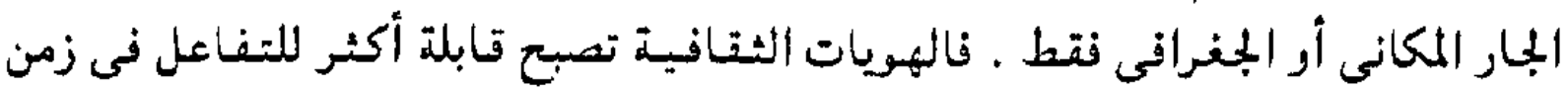

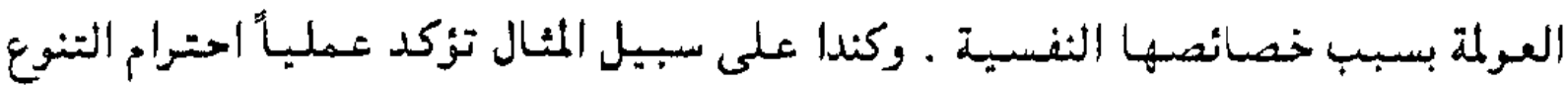

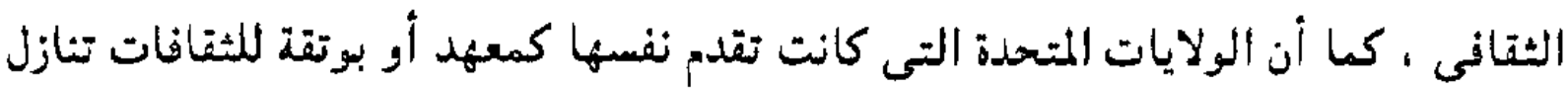

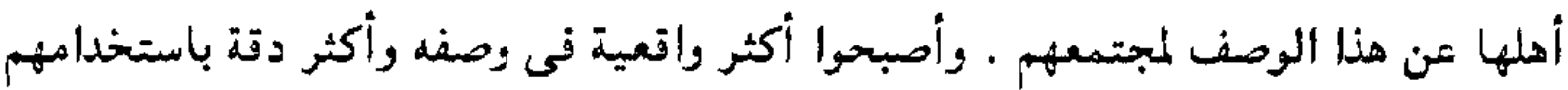

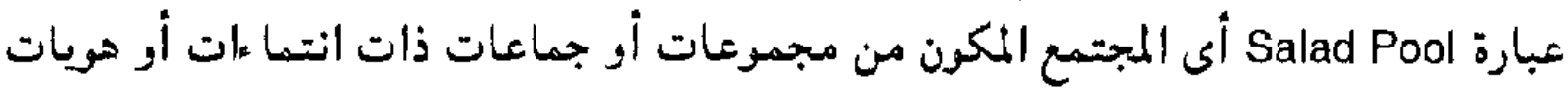

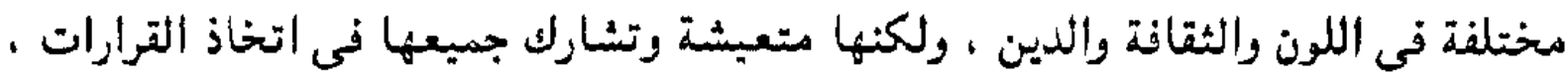

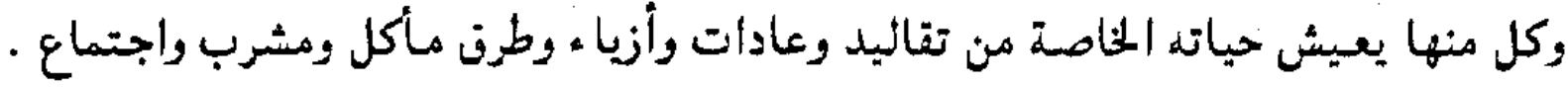

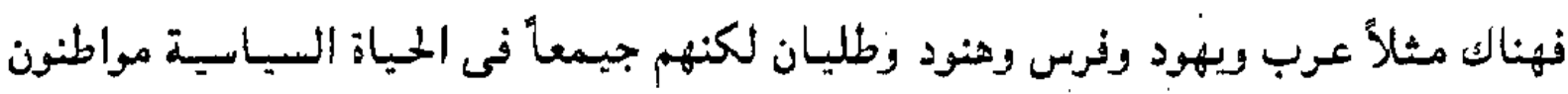
متساوون فى الخقون (Y9)

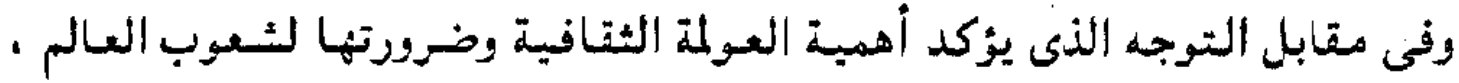

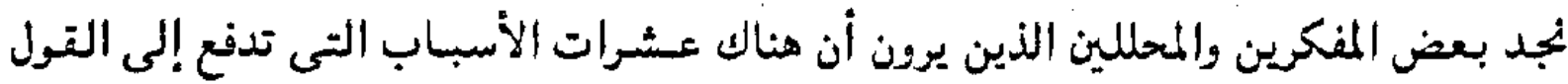

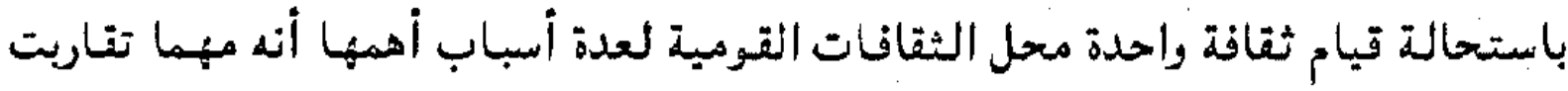

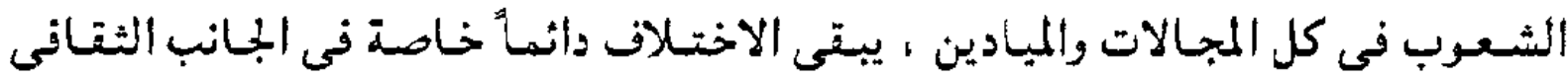

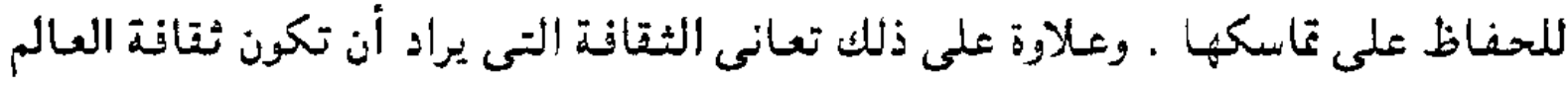

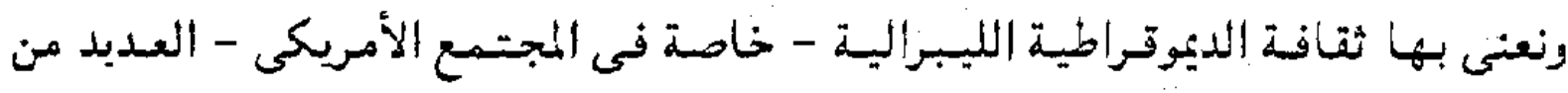

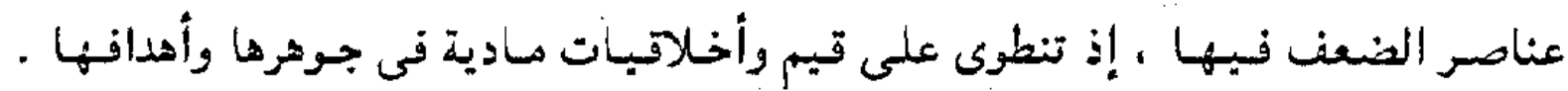

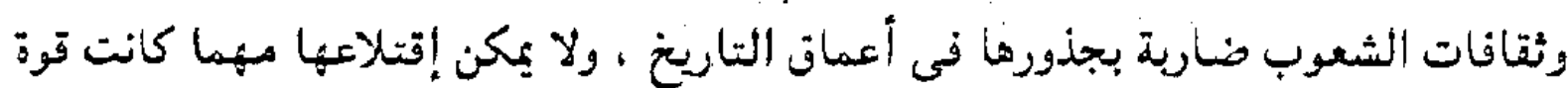

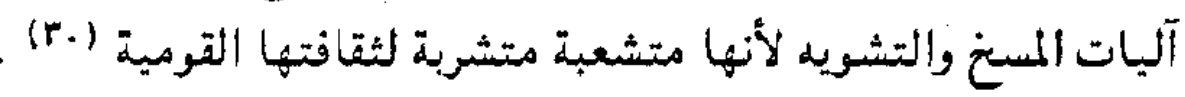

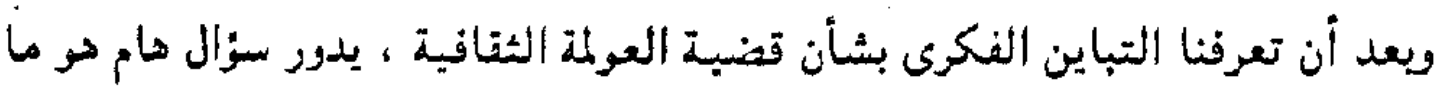

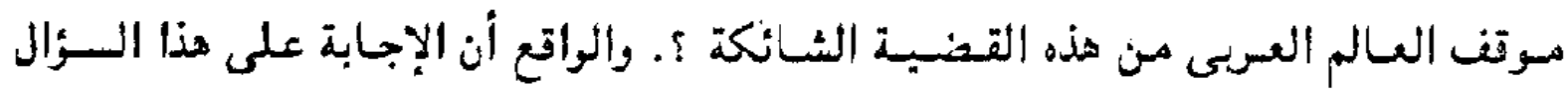

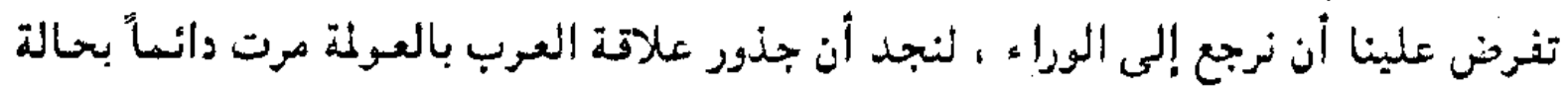

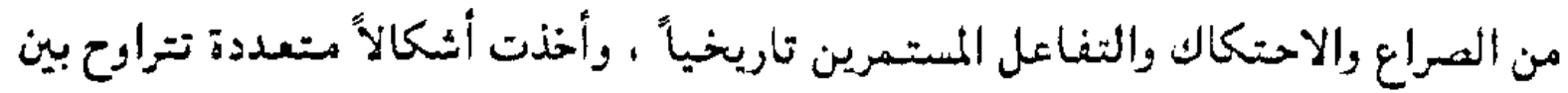

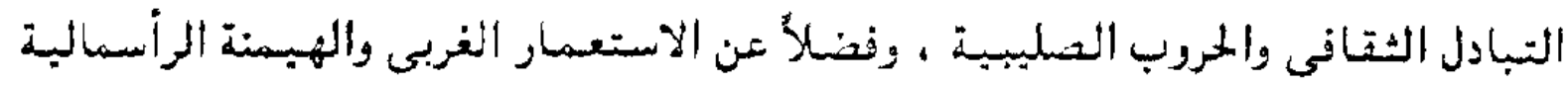

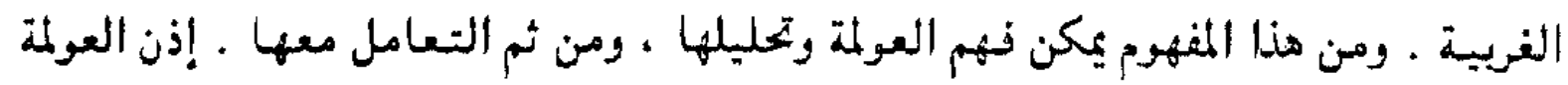

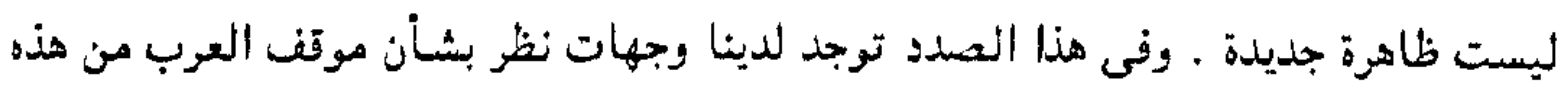

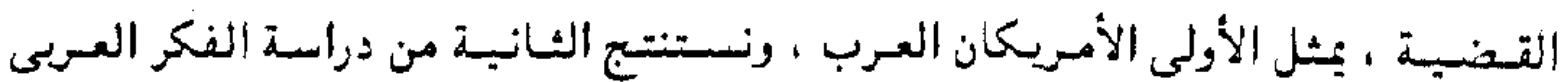




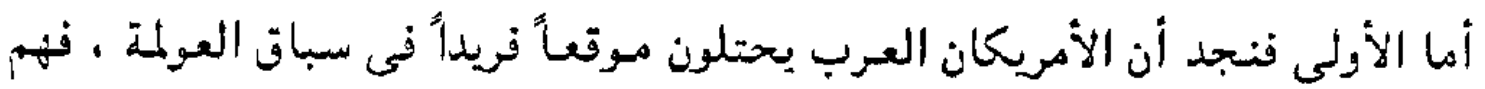

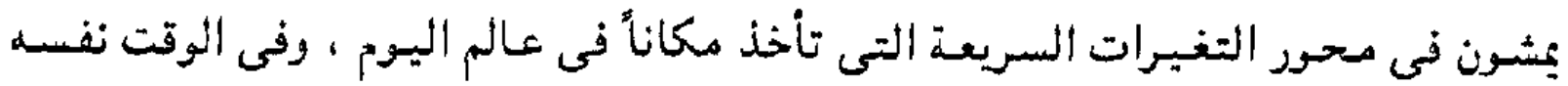

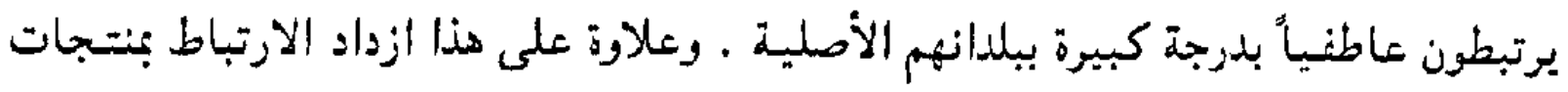

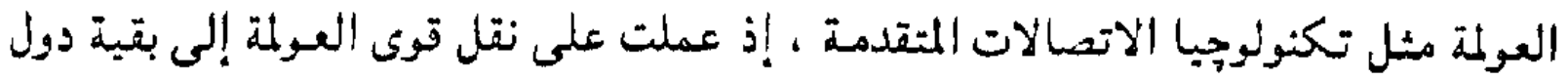

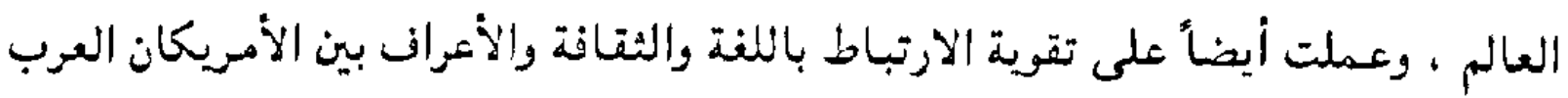

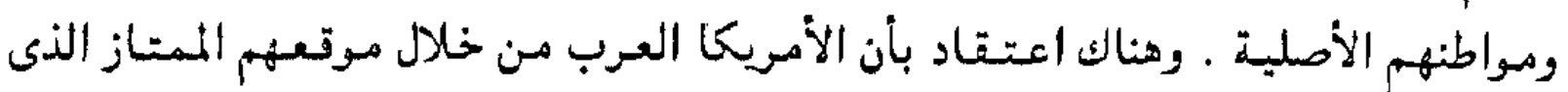

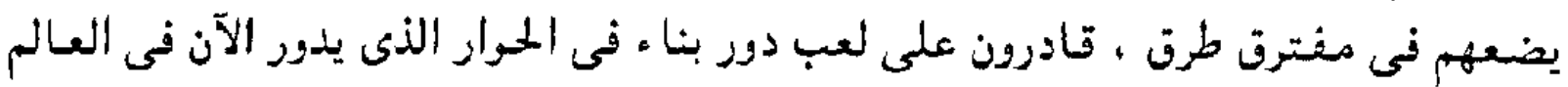

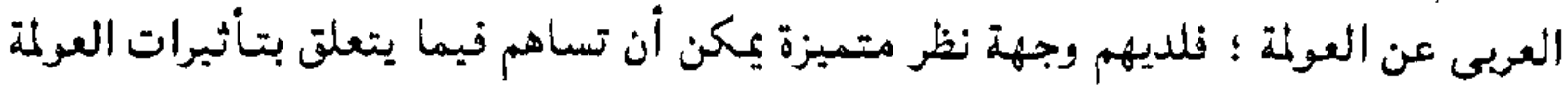

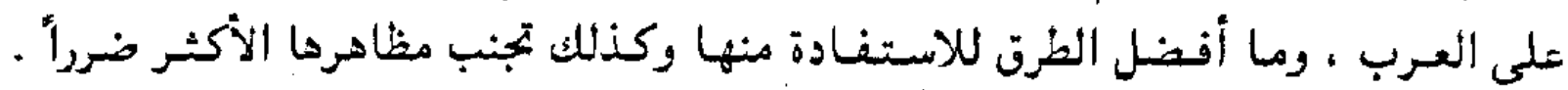

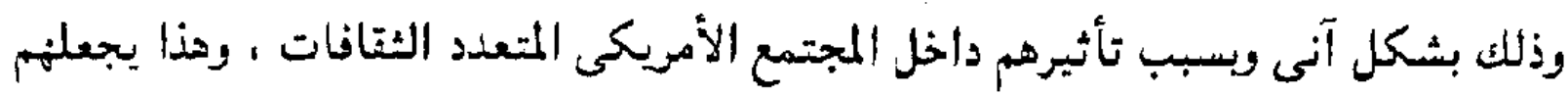

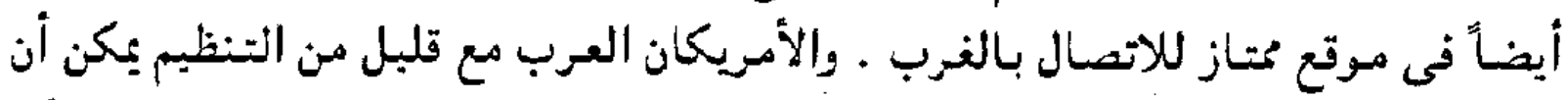

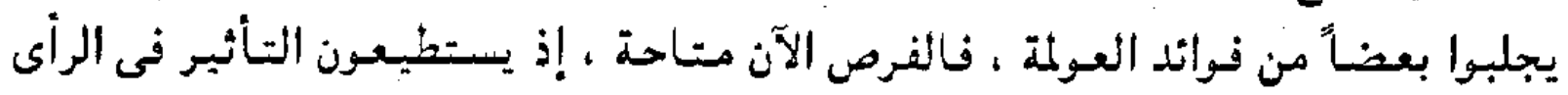

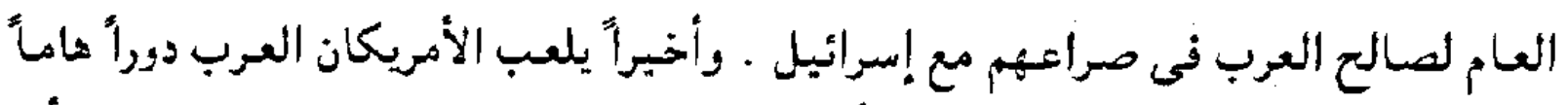

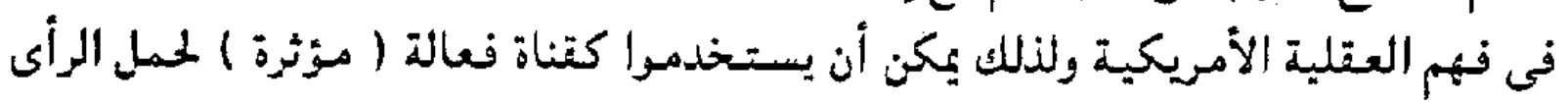

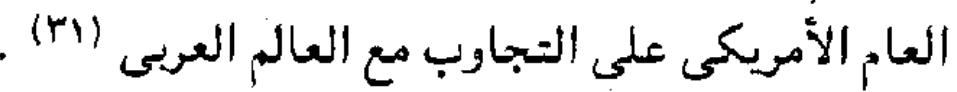

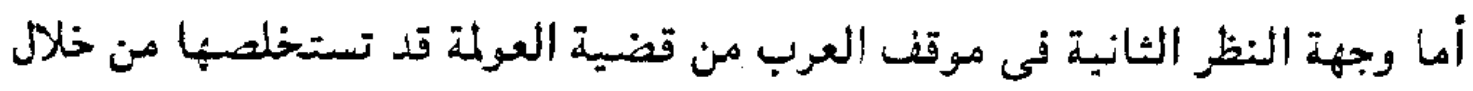

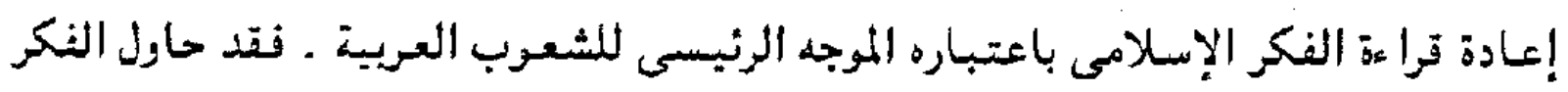

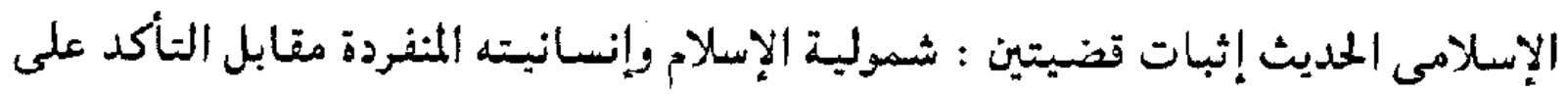

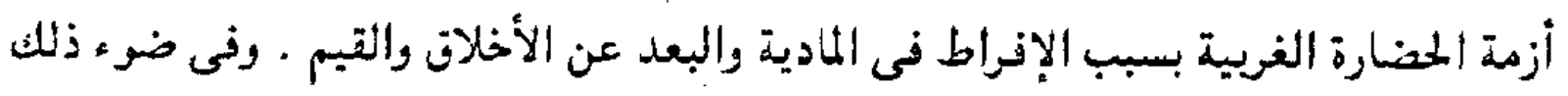

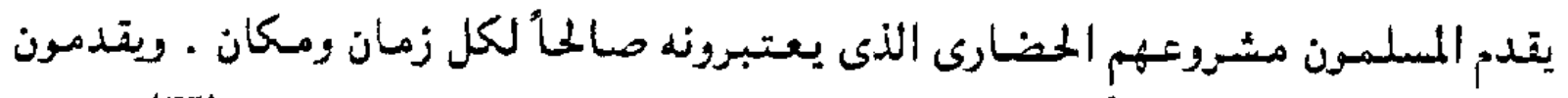

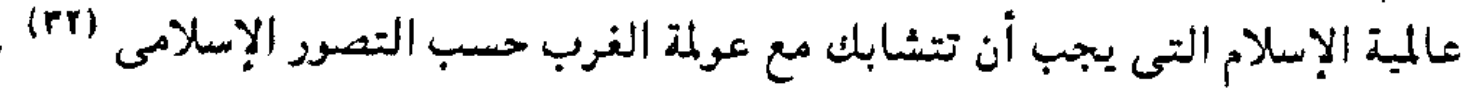

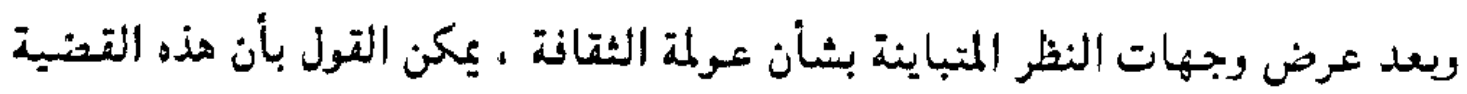

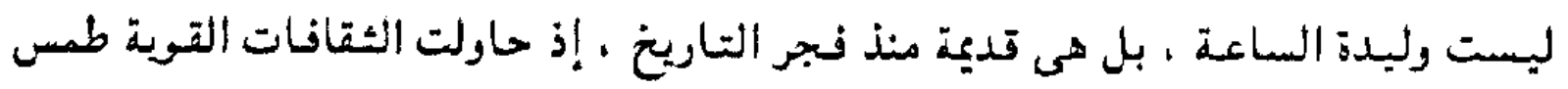

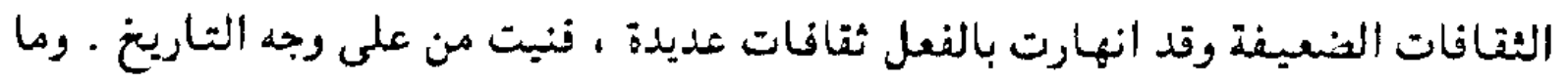

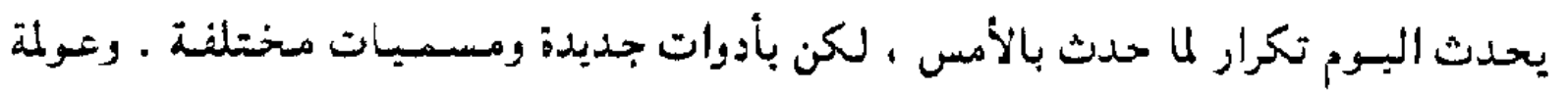

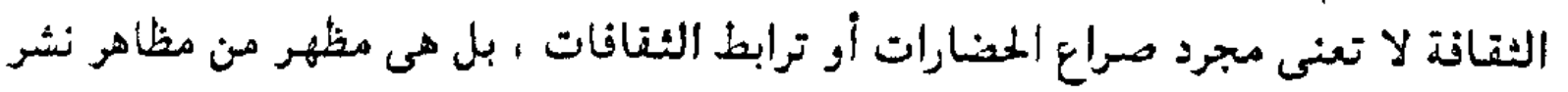

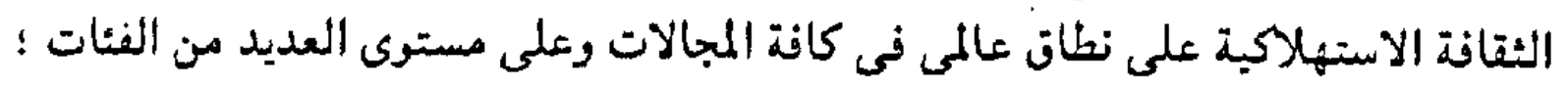

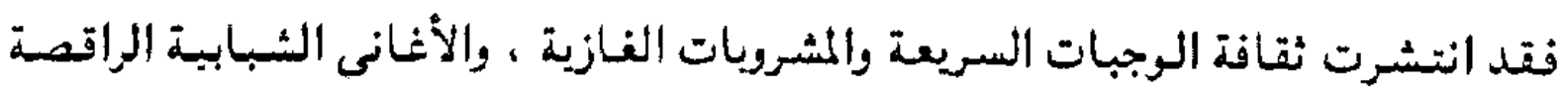


وملابس الماركات العالمية ومشاهدة الأفلام المثيرة ، ويون شك تسعى هذه الثقافة إلى ربط

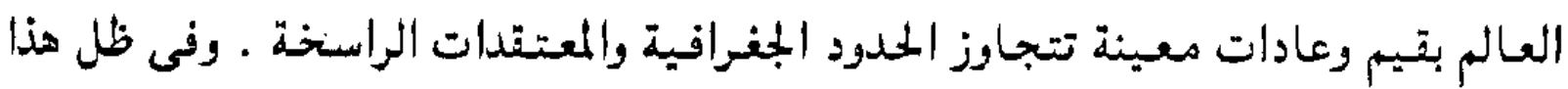

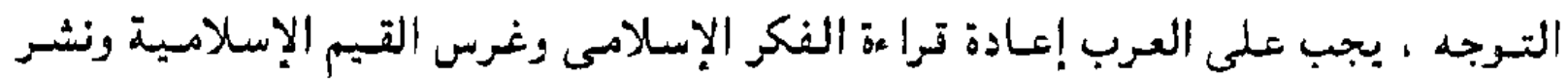

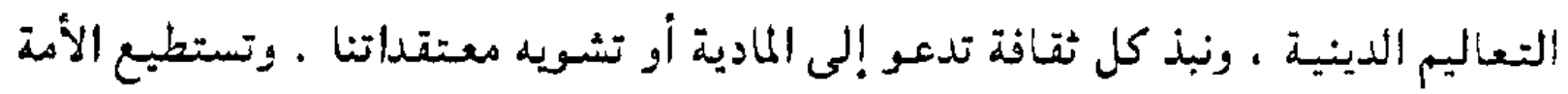

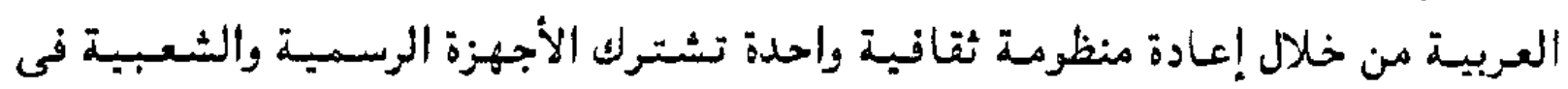

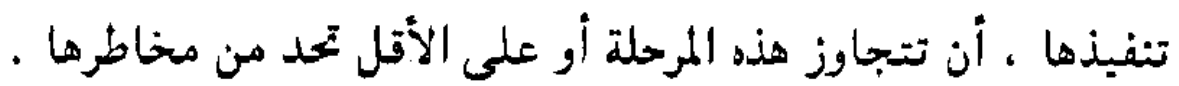

\section{ثاثثاً ، البيث التتلفزيوذى المباشر والثهوية الثقاثية العربية.}

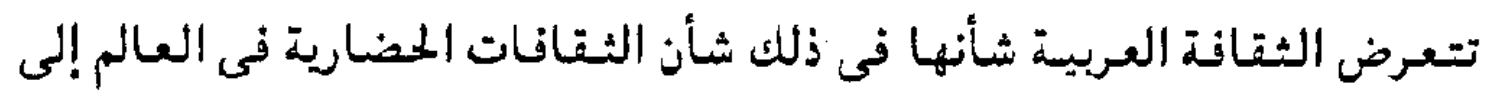

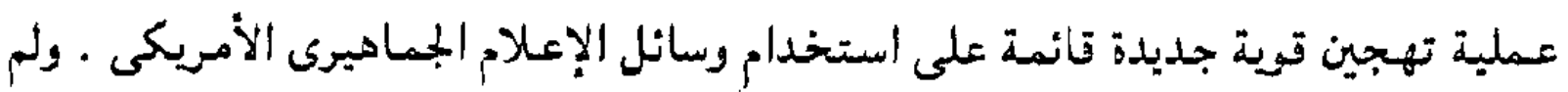

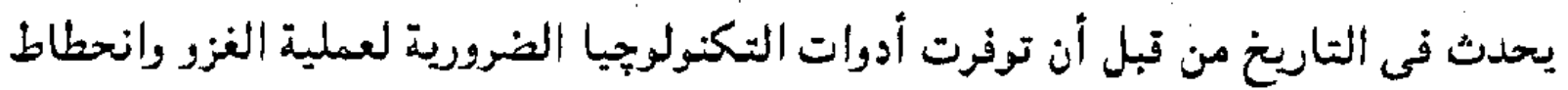

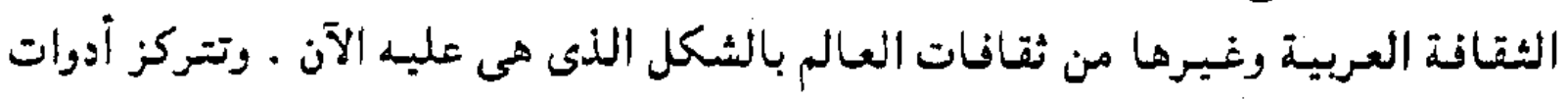

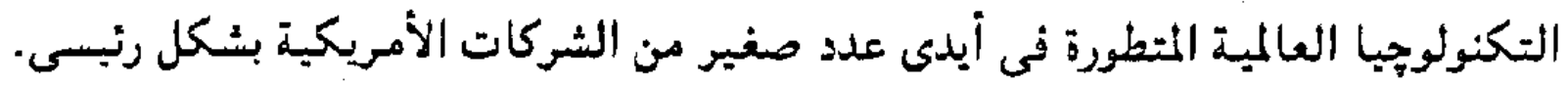

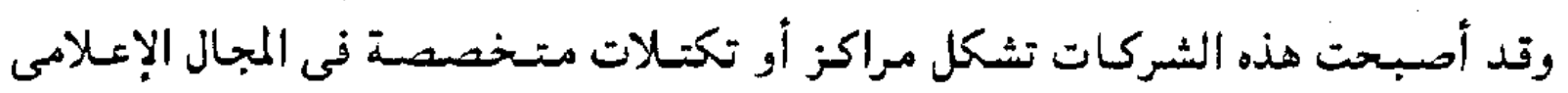

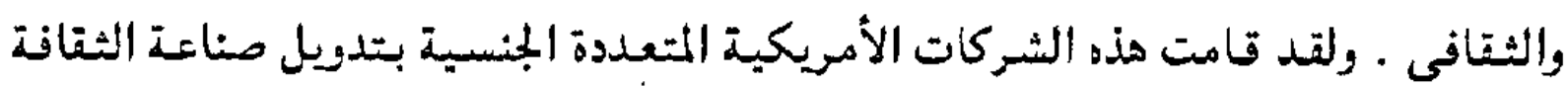

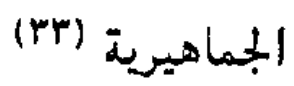

وتسعى الولايات المتحدة لتسليط الضوء على الثقافة الأمريكية باعتبارها نوذجاً لثقافة عالمية يجب أن تنتشر عبر شبكات الاتصالات الدولية دون أية عواتث من أي مكان.

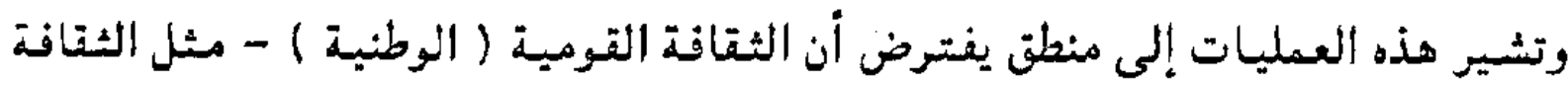

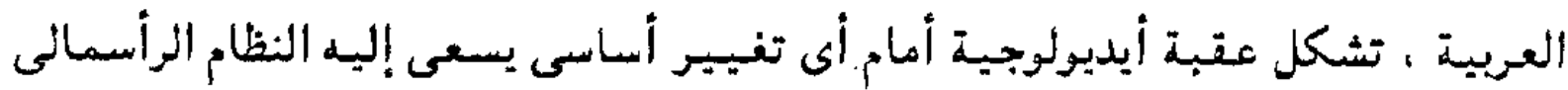

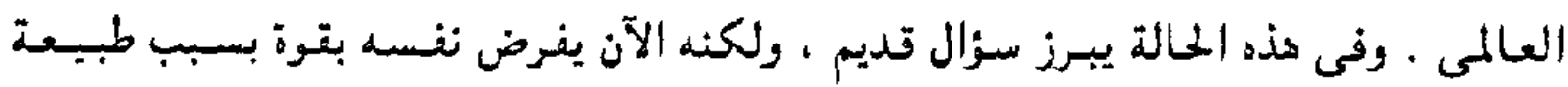

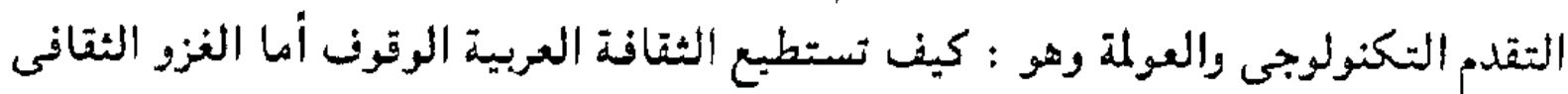

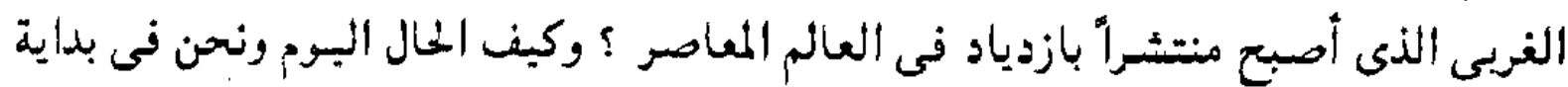

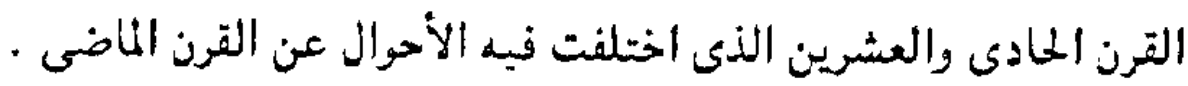

وفى الصفحات التالية نماول الإجابة على هذه الأسنلة وغيرها من خلال مناقشة

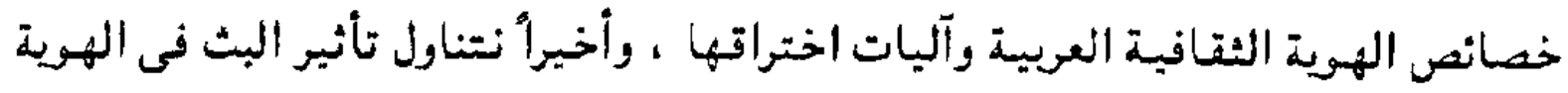

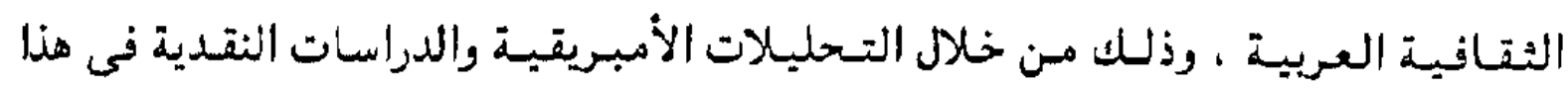




\section{1 - خصائص الموية الثقافية العربية :}

أصبح الحديث عن الهوية الثقافية العربية أمرأ ضرورياً وذلك لها آلت إليه أحوال

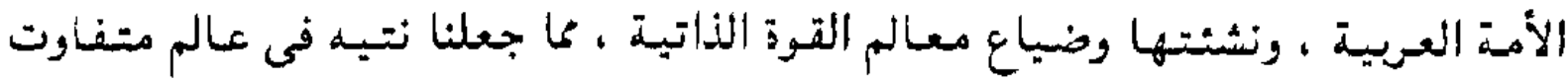

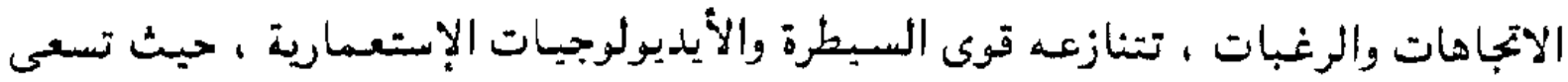

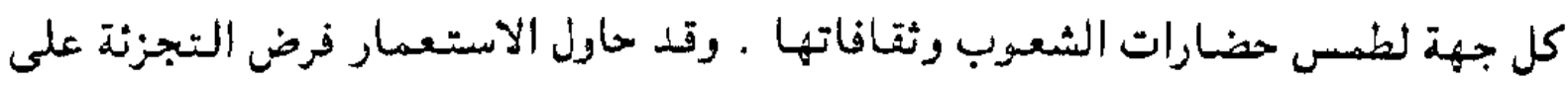

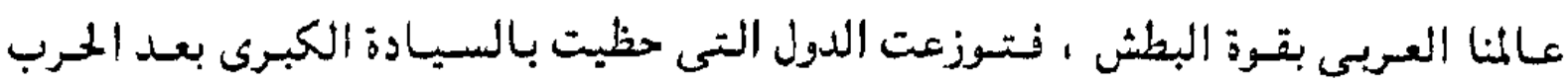

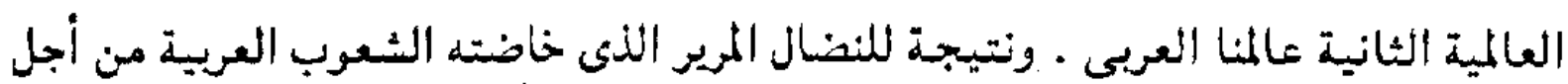

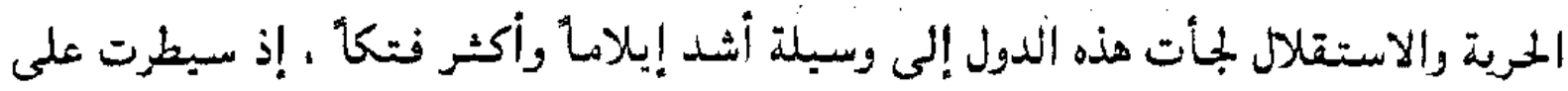

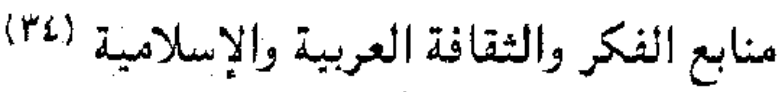

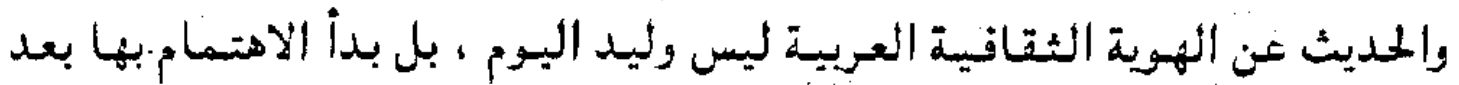

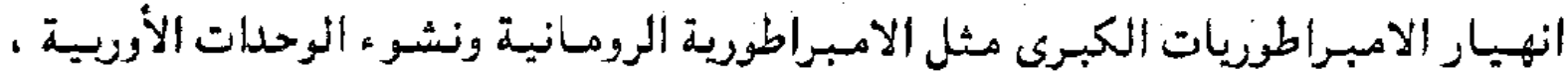

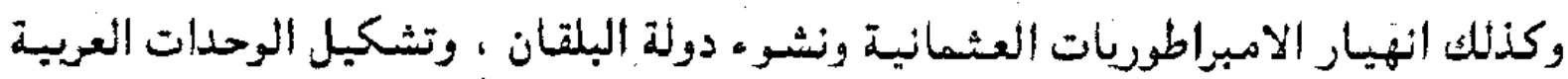

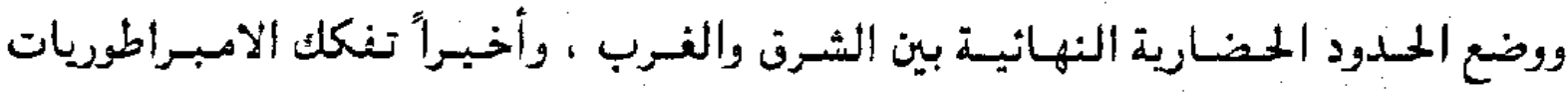

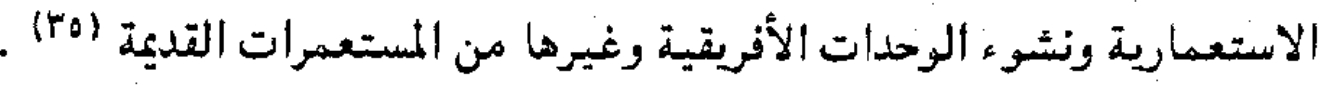

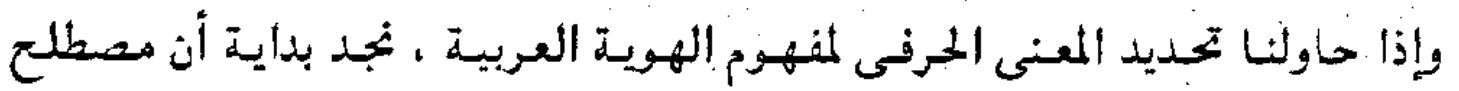

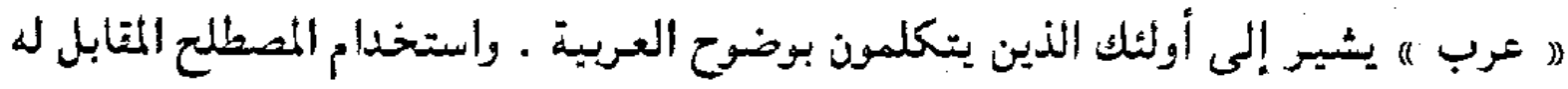

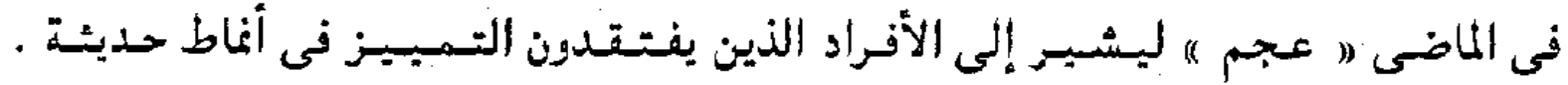

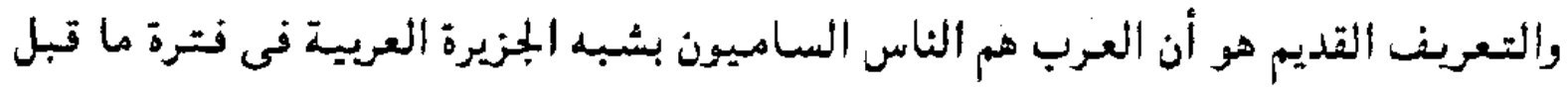

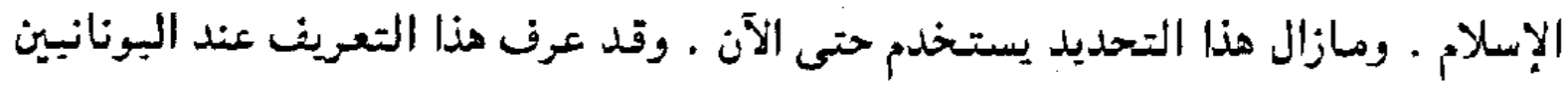

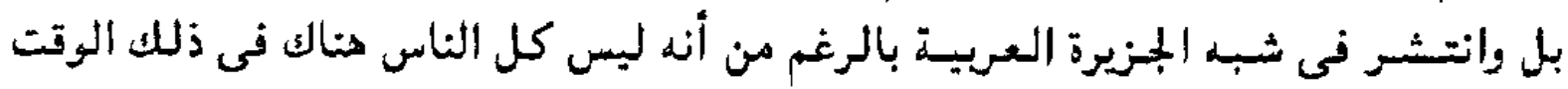

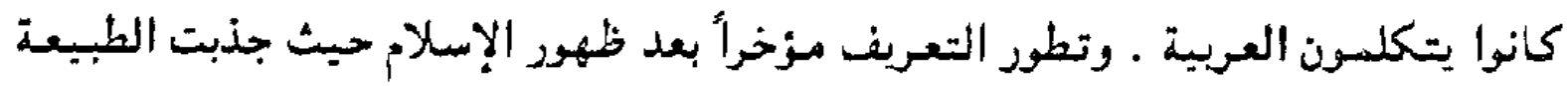

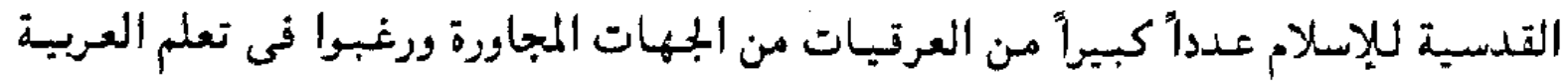

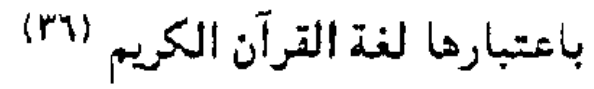

ويوجد ارتباط وثيق بين الهرية الثقافية العريية والهوية الثقانية الإسلاميسة .

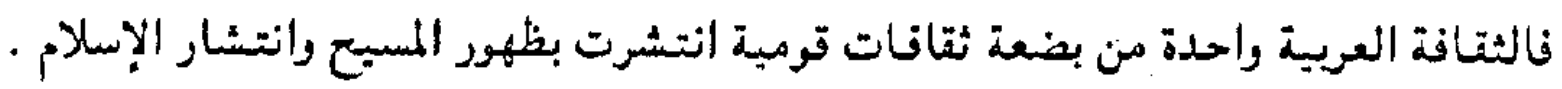

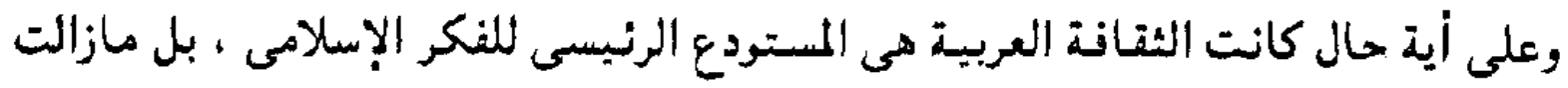

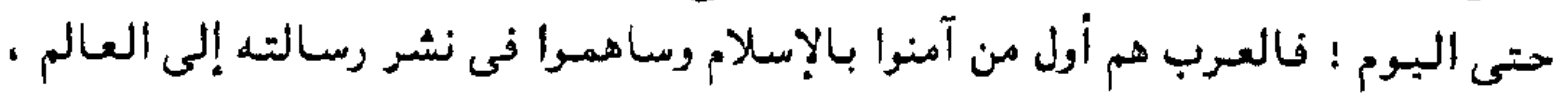

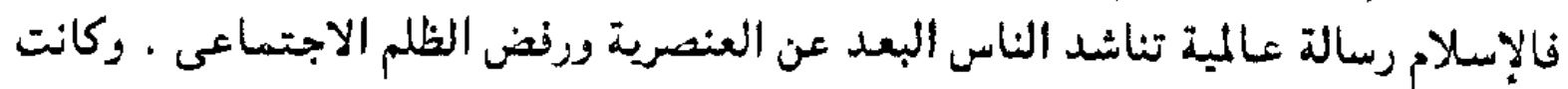




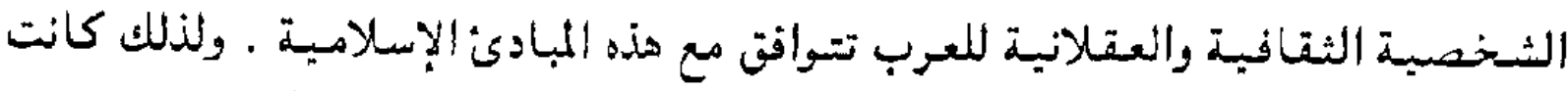

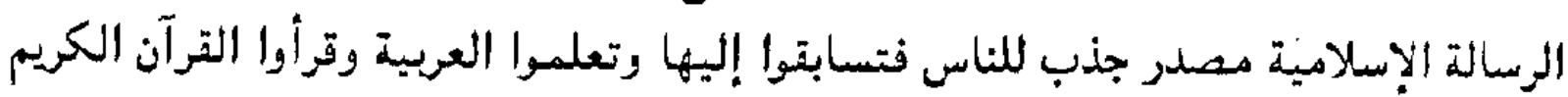

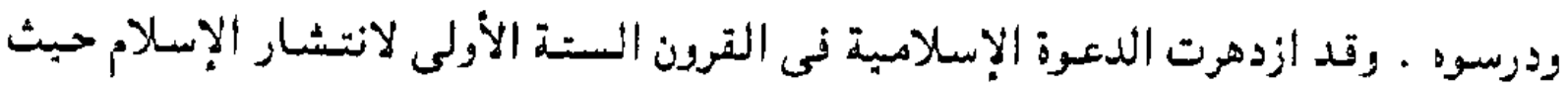

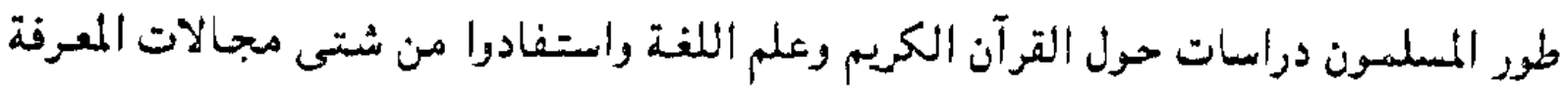

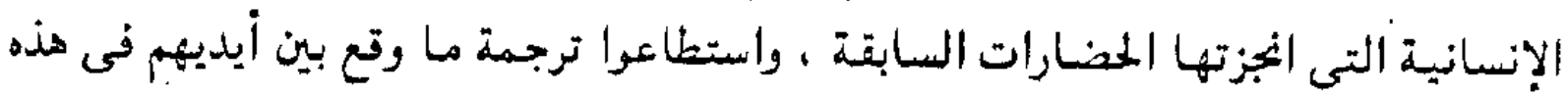

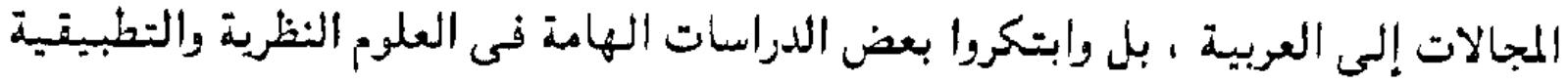

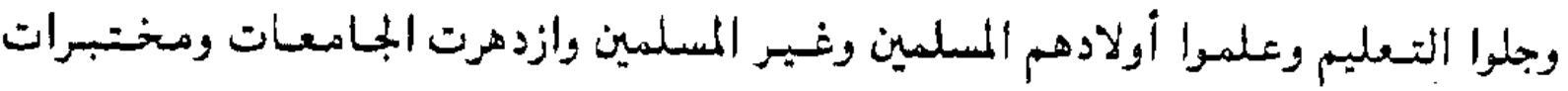

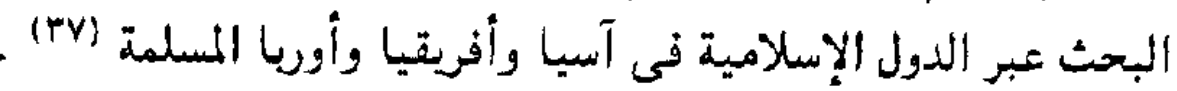

وكان العرب باحثين جاين في مجالات المعرفة كافة ، لكن ما الذى كان يحفزهم

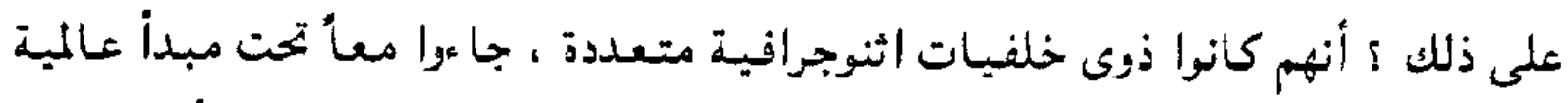

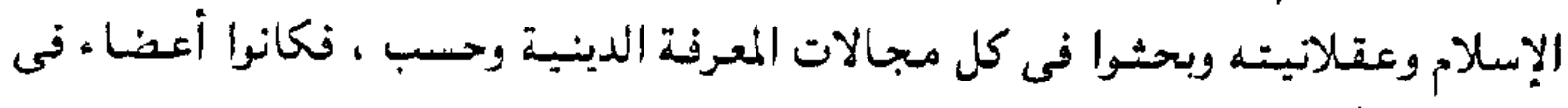

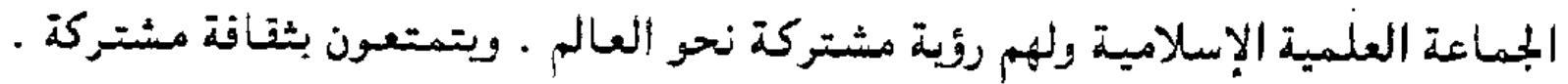

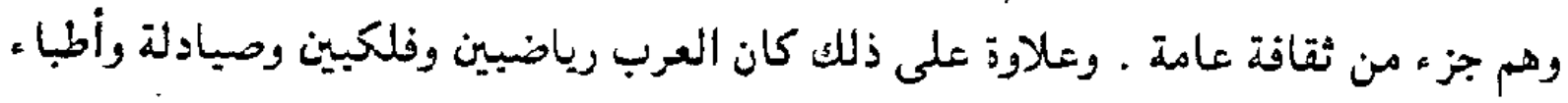

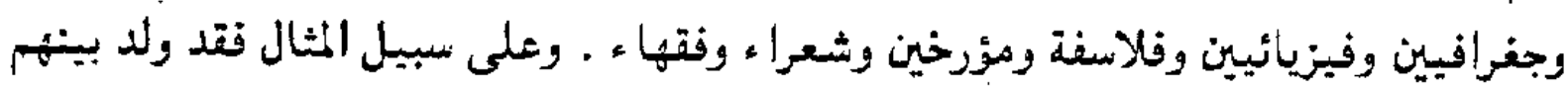

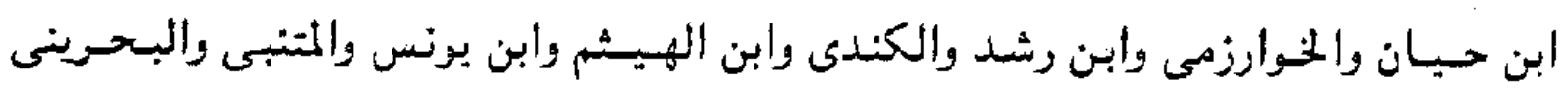

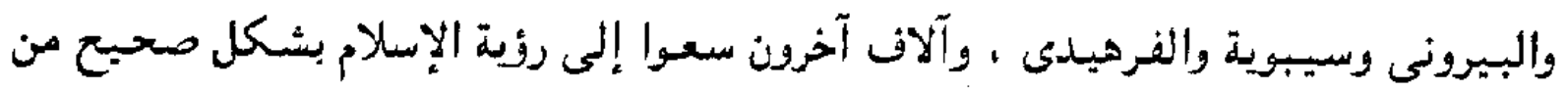

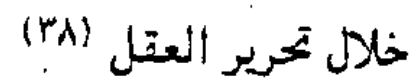

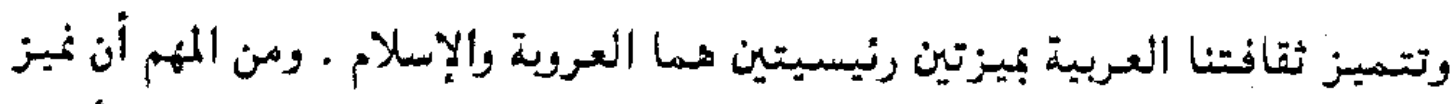

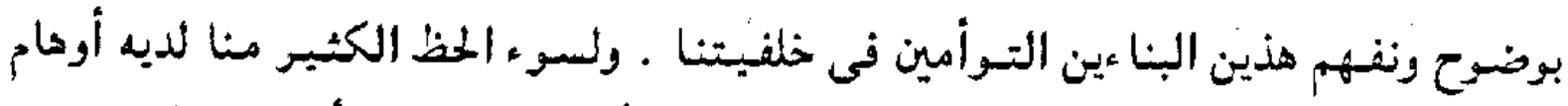

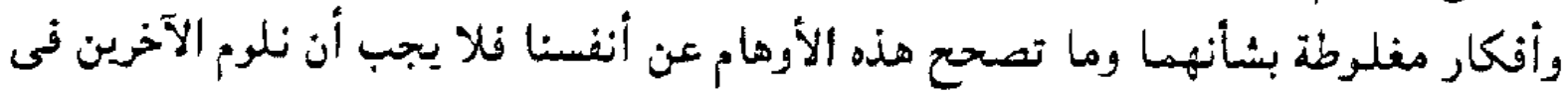

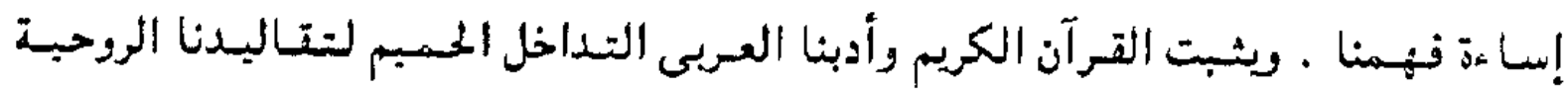

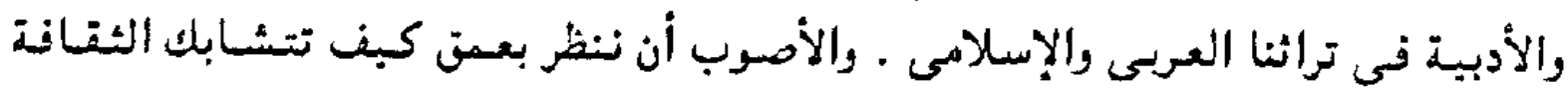

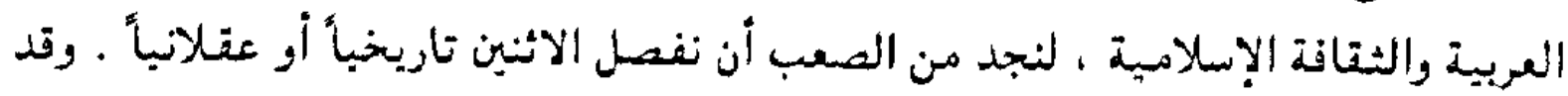

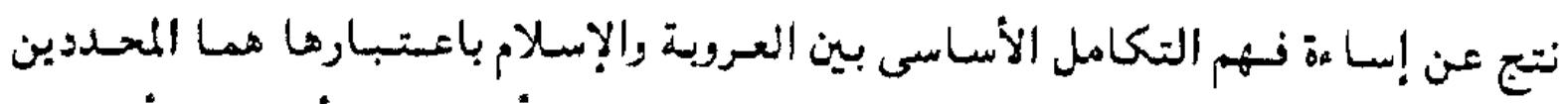

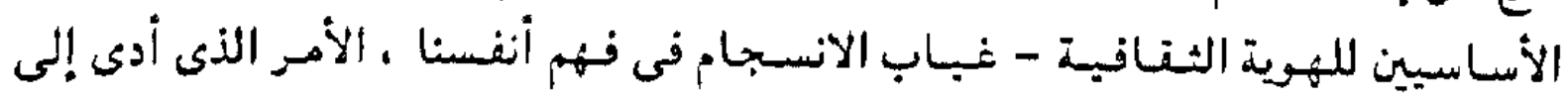

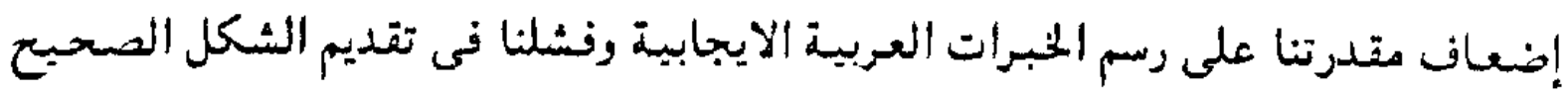
لحياتنا العريبة (ra) 
وإذا ها حاولنا تحديد هويتنا الثقافية تحديداً دقيقاً ، وجب التركيز على إبراز تراثنا

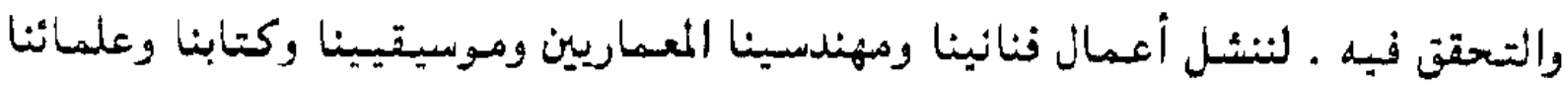

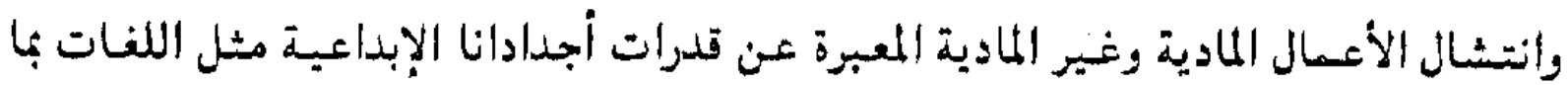

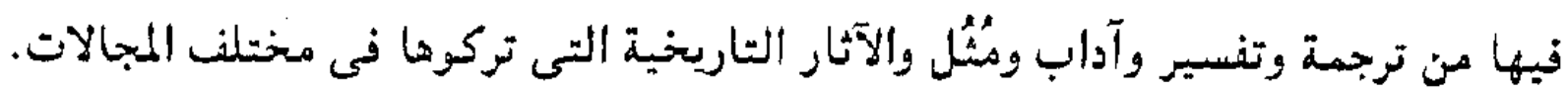

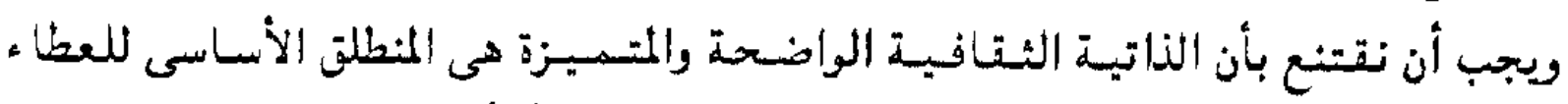

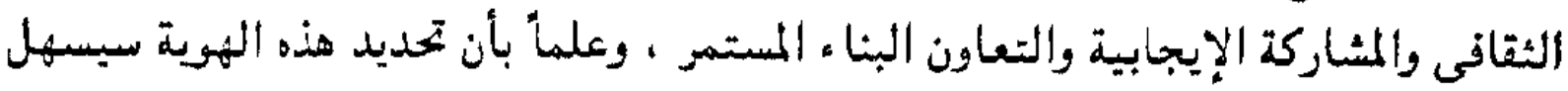

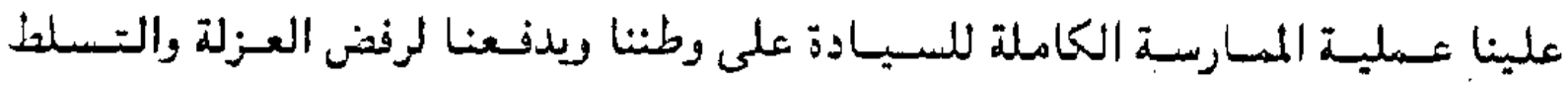

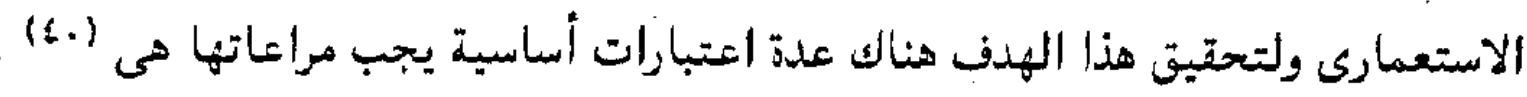

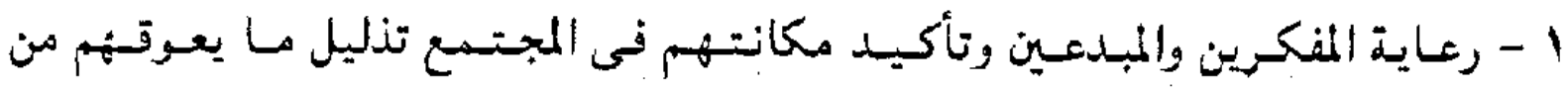

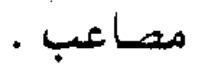

r - تعاون أجهزة الثقافة والتعليم والإعلام والتهنية فى الدول العريـة لدراسة هذه الهوية

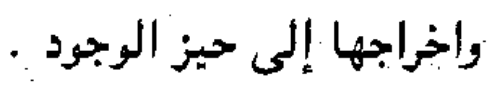

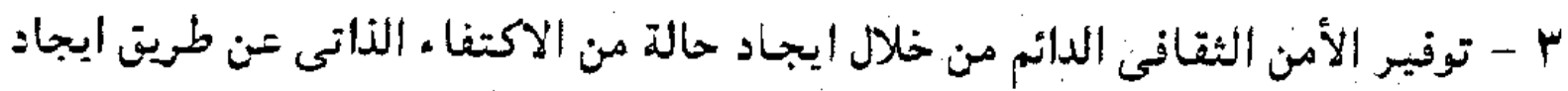

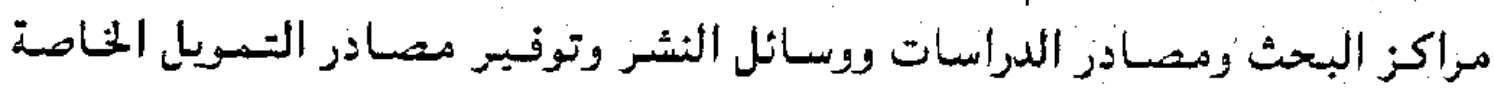
بشروعات التنمية الثقافية وتوضيح الثهوية الثقافية .

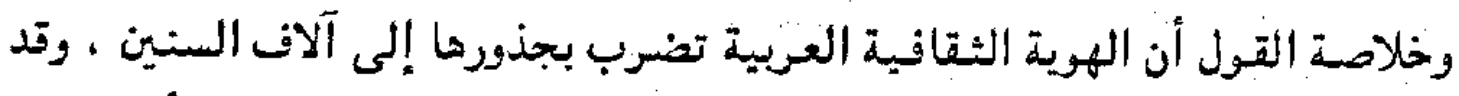

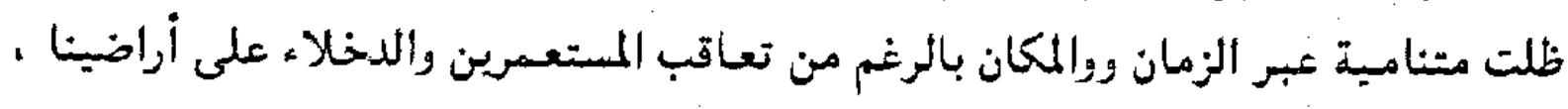

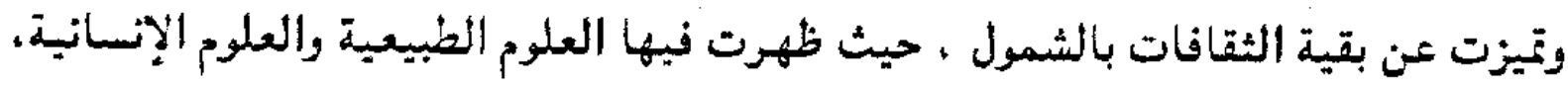

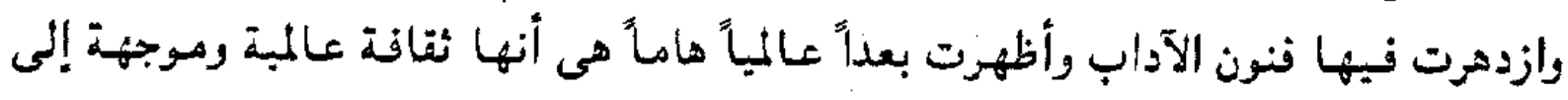

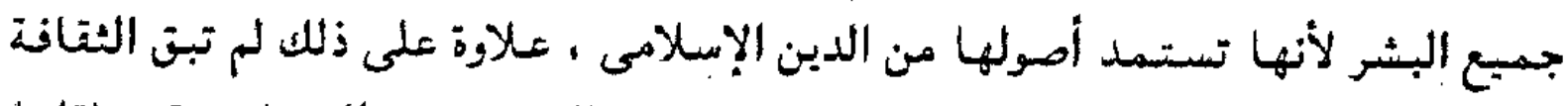

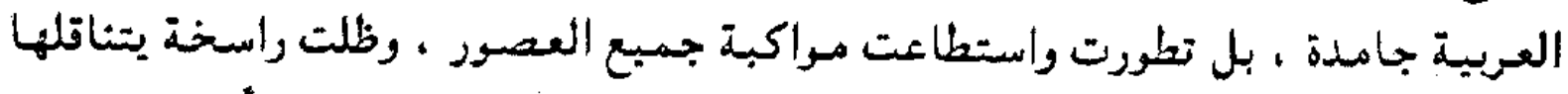

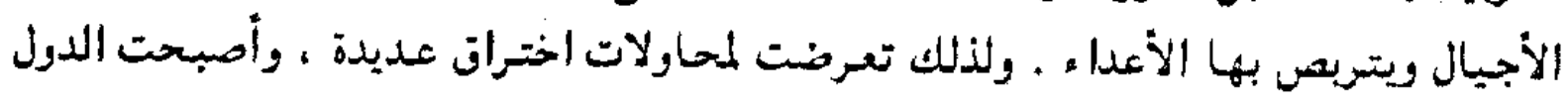

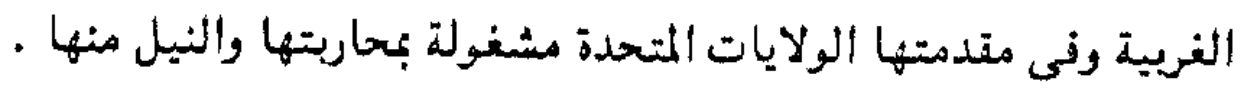

\section{r - آليات اختراق الموية الثقافية العربية :}

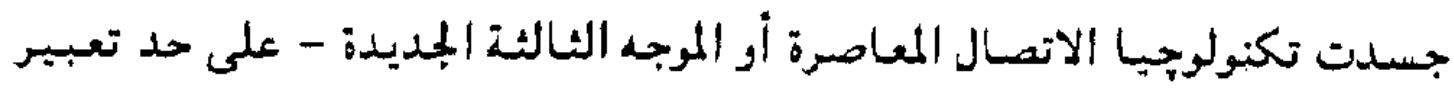

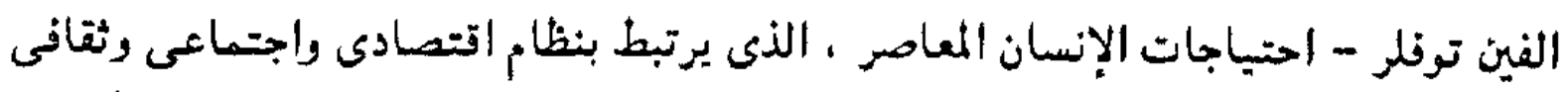

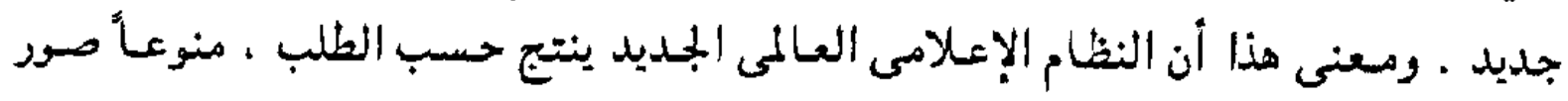




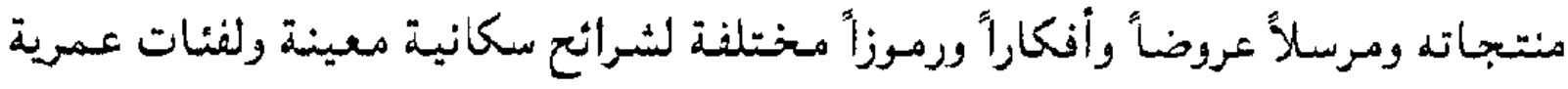

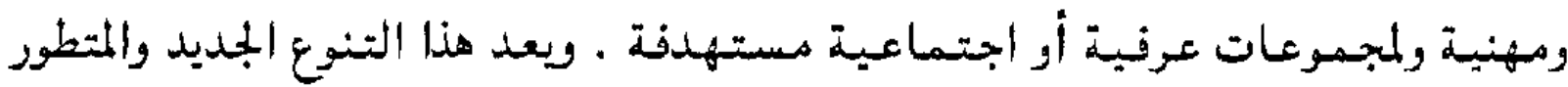

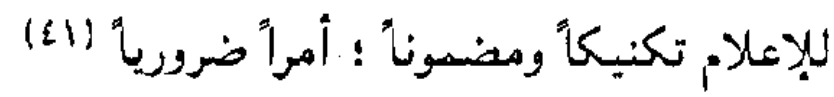

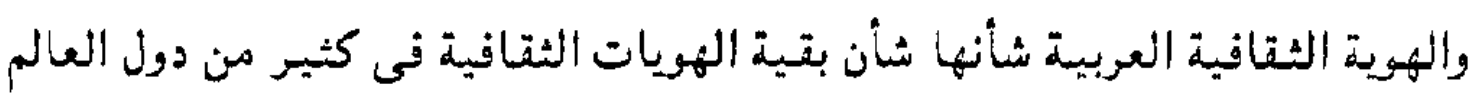

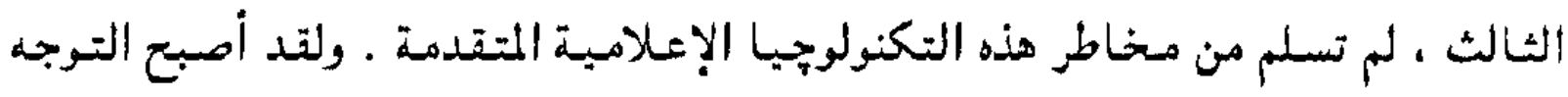

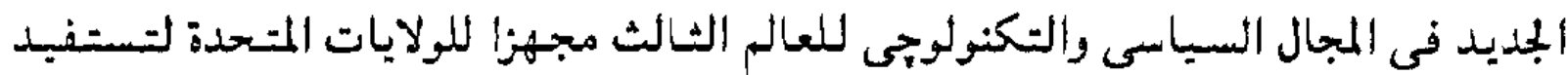

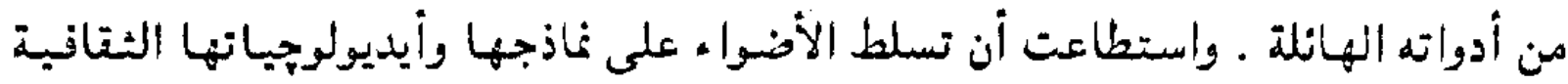

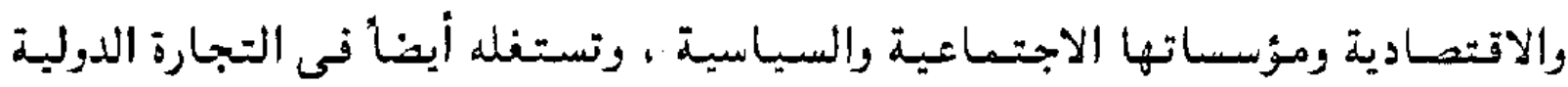

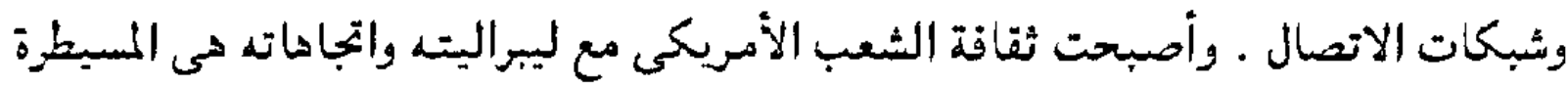

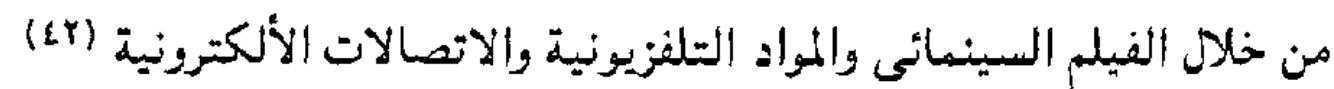

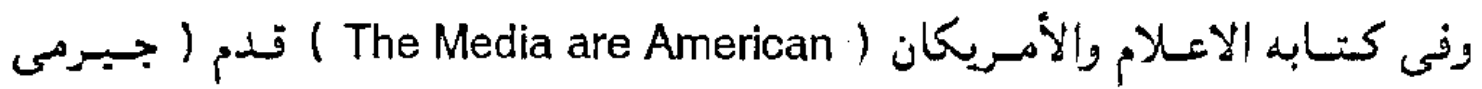

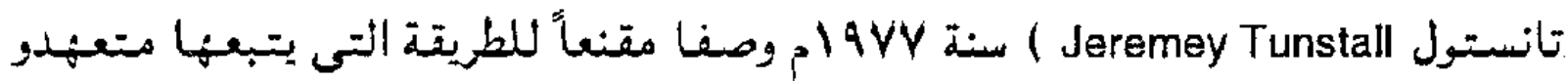

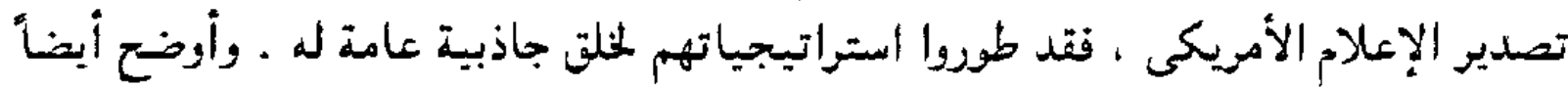

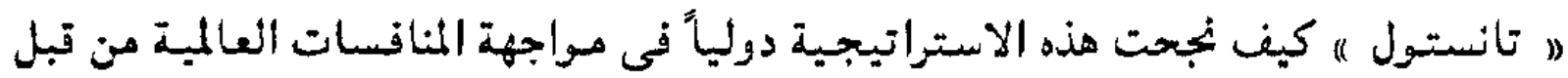

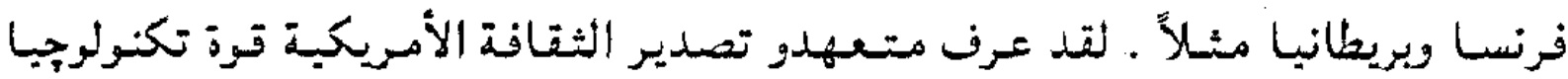

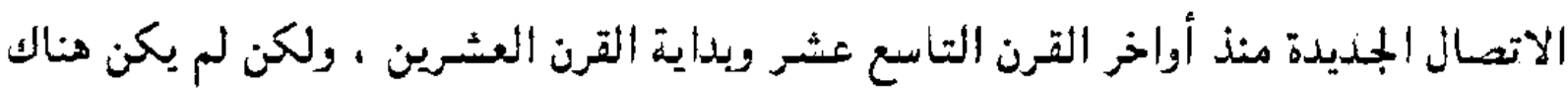

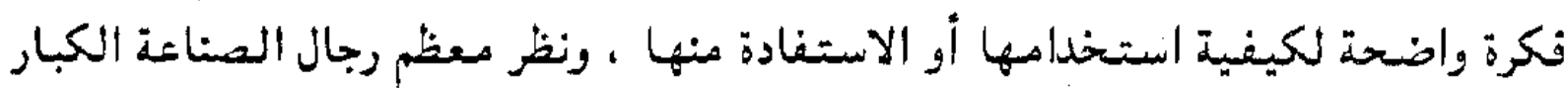

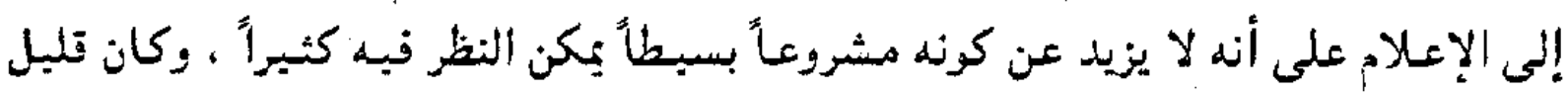

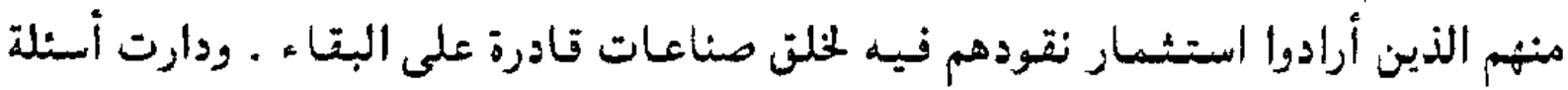

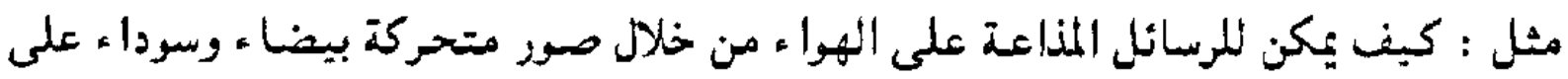

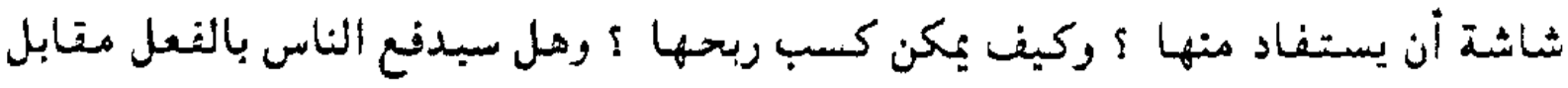

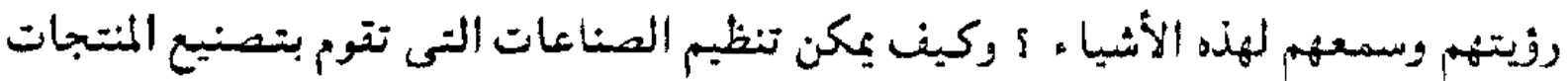
الثنافية وتسويقها ؟ لقد فشلت معظم المحاولات الأولى للإجابة على هذه الأسئلة ، ولكن الهن

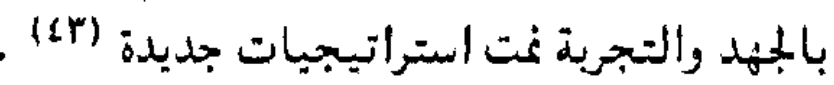

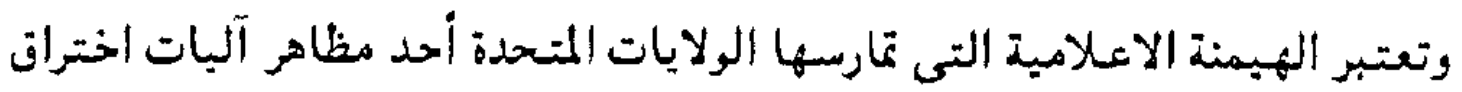

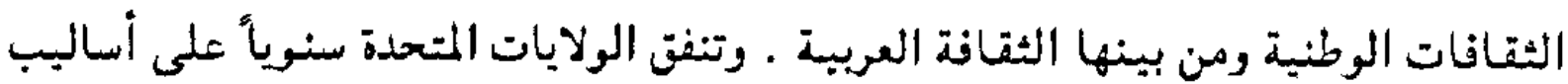

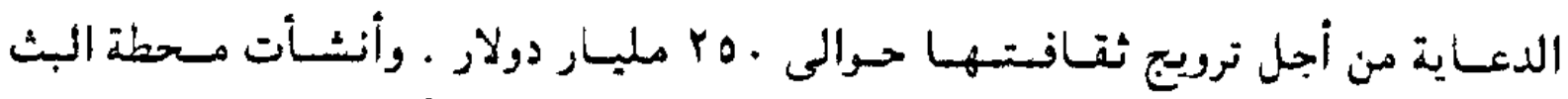

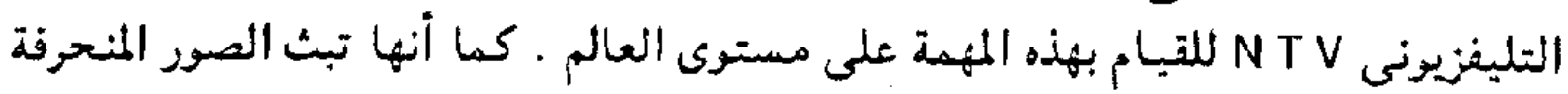




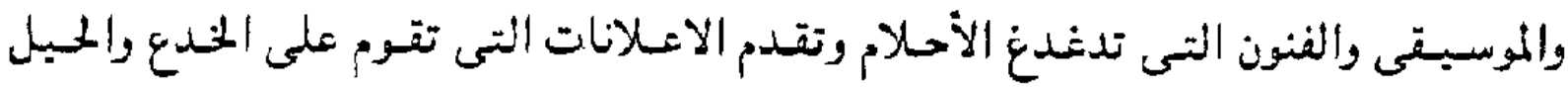

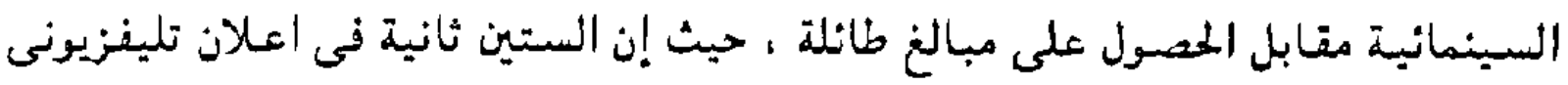

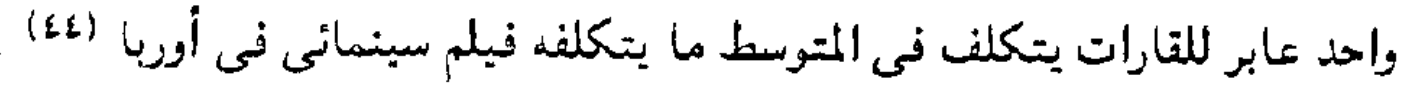

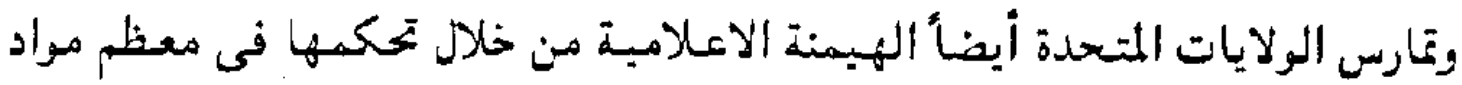

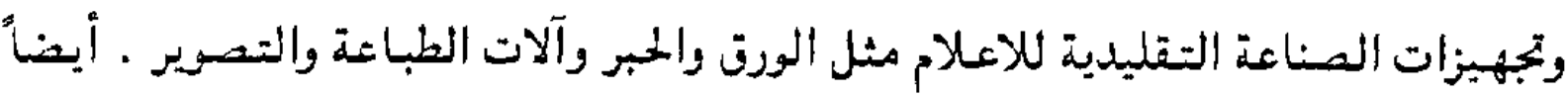

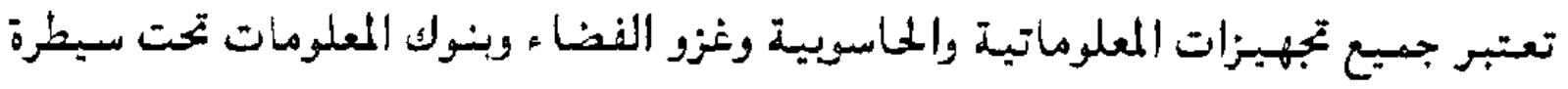

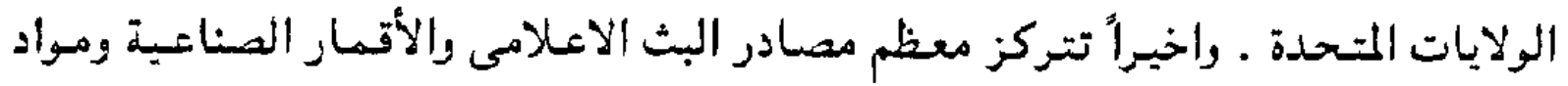

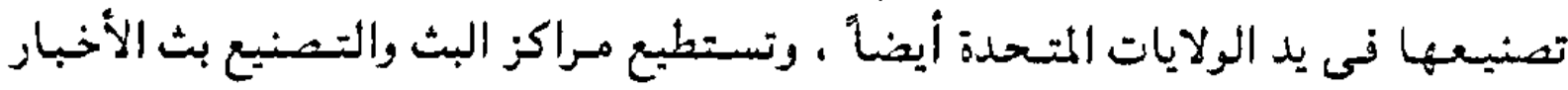

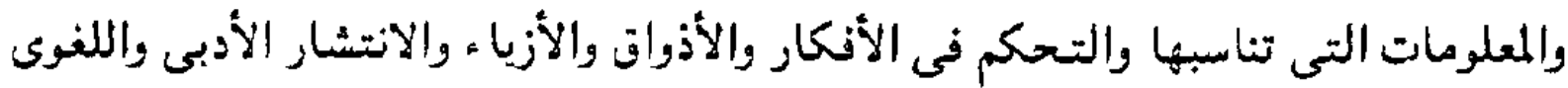

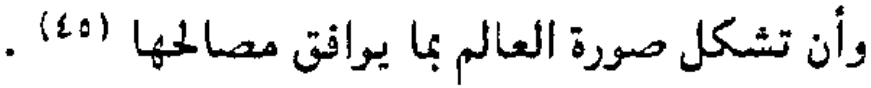

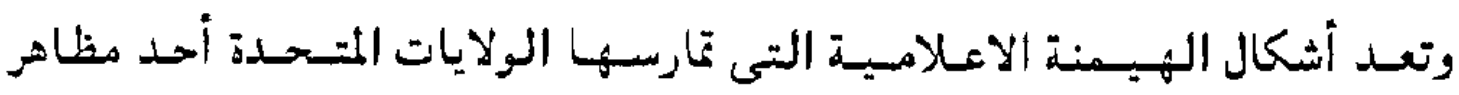

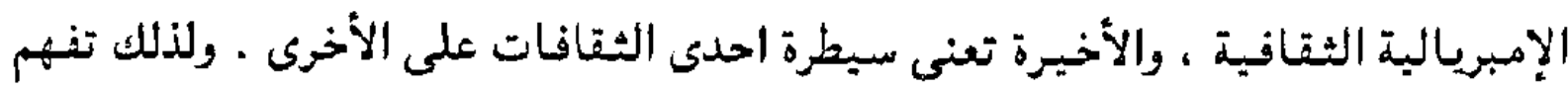

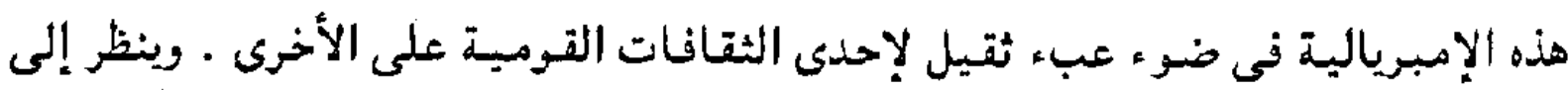

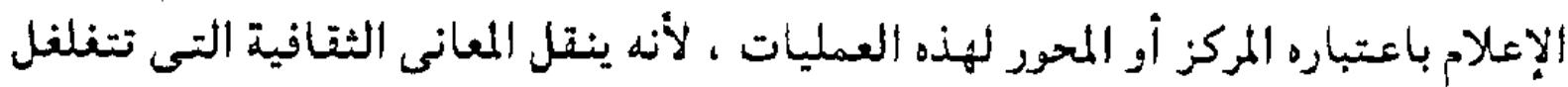

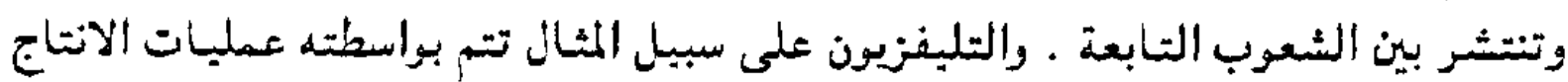

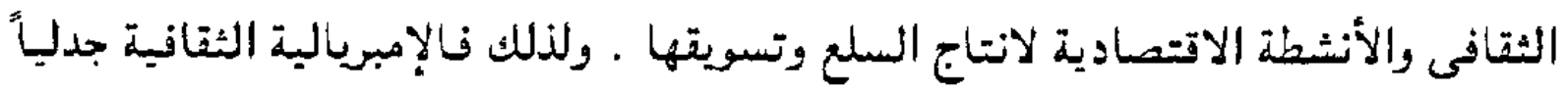

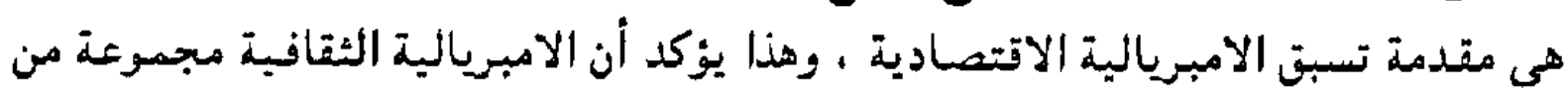

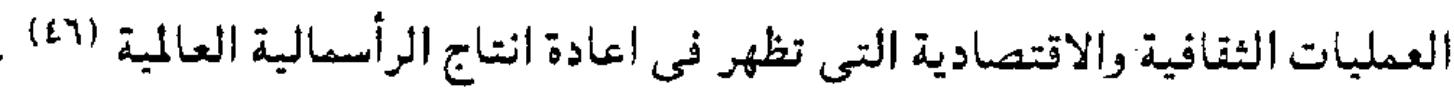

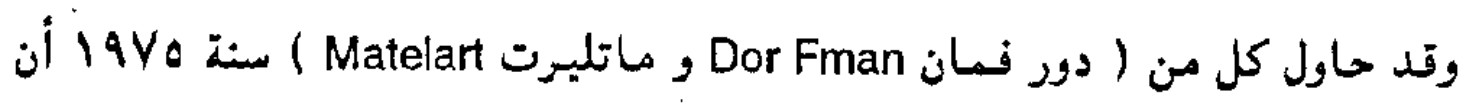

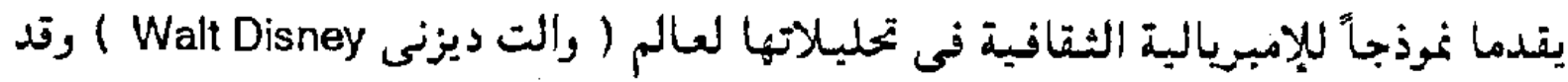

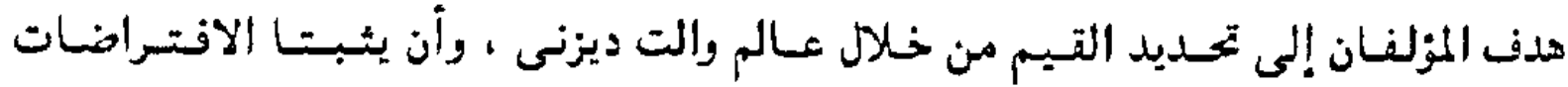

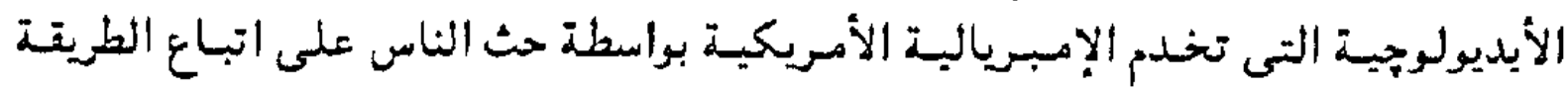

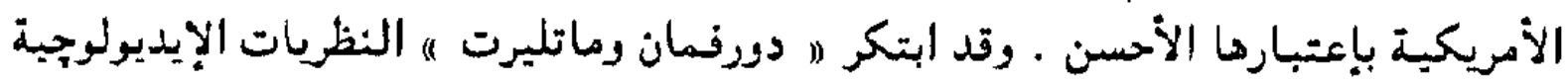

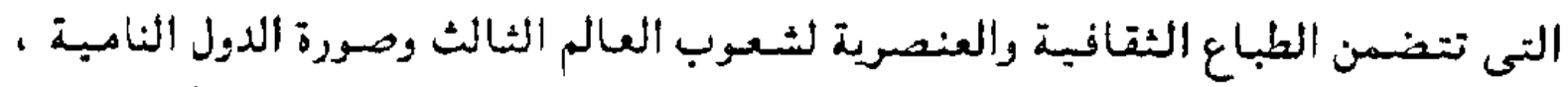

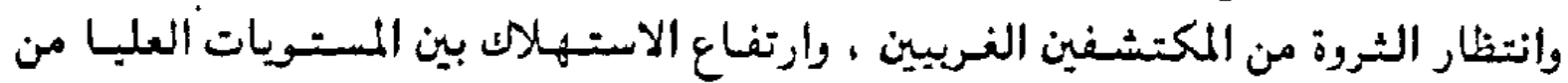

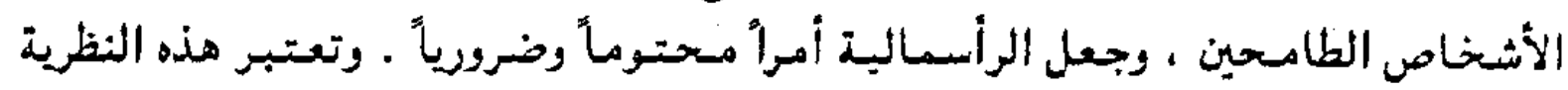

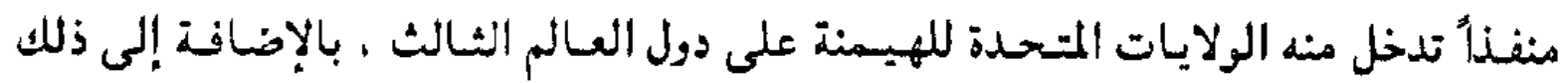

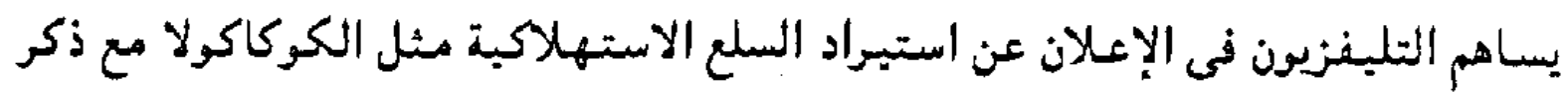




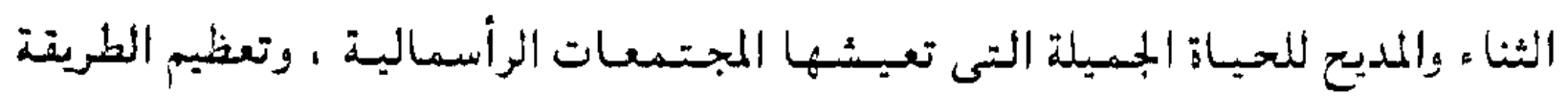
الأمريكية (2V)

ونتيجة لإنتشـار الإمبريالية الثقافية الأمريكية وفى ظل عولمة الاعلام ، تأثرت

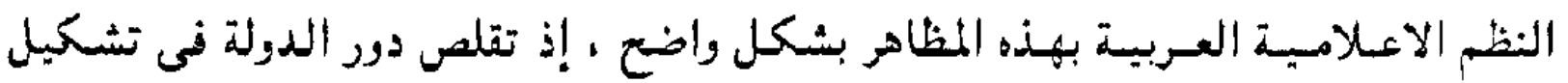

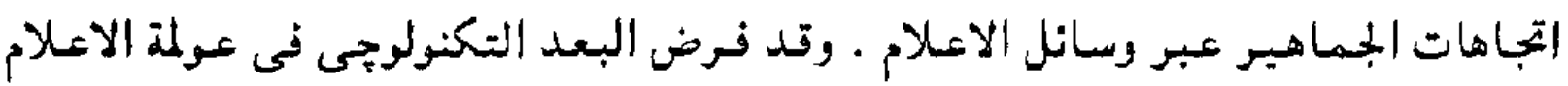

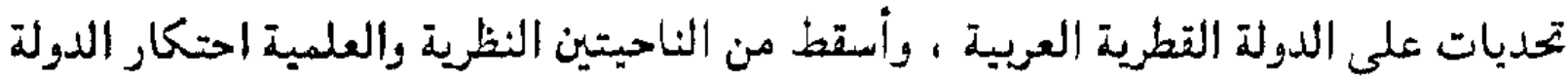

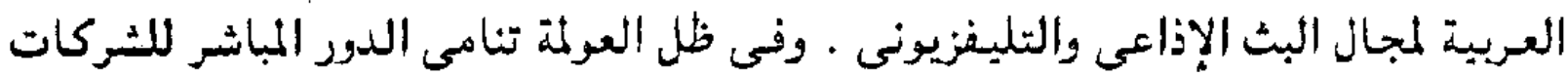

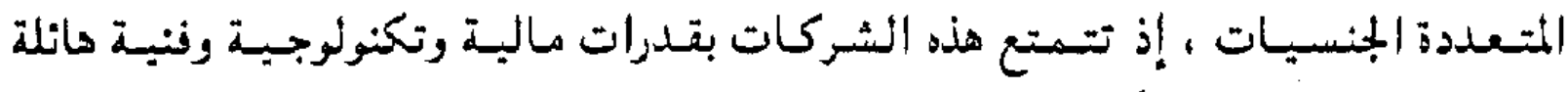

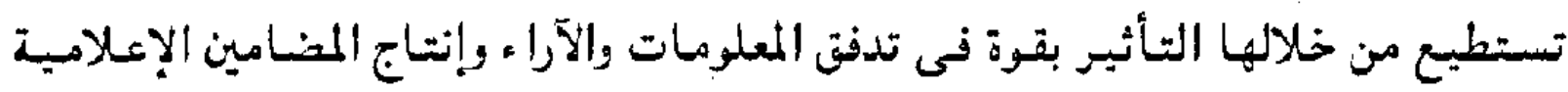

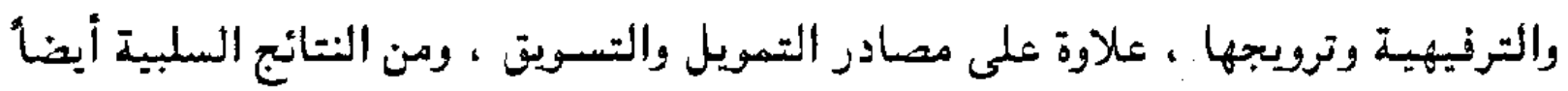

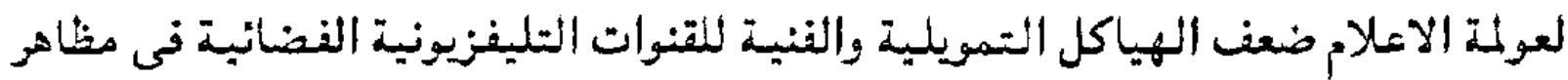

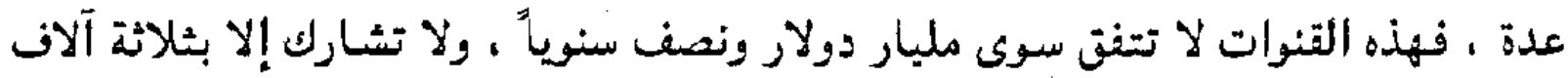

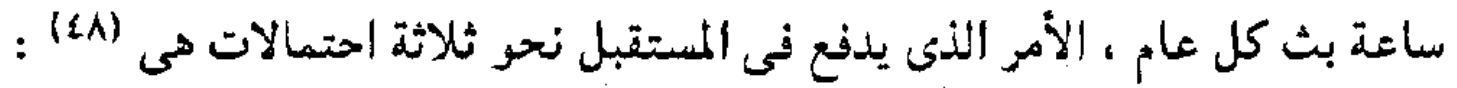

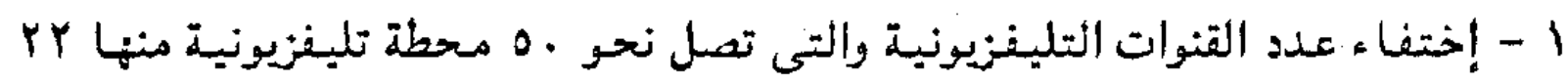

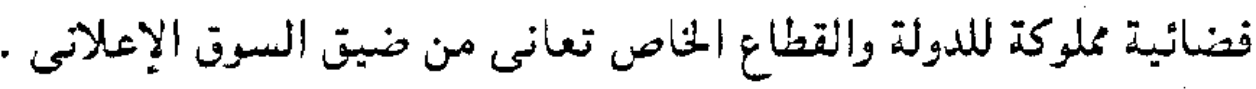

r - إندماج بعض التنوات الفضائية التابعة للقطاع الحاص ، وذلك حتى تستطيع البقاء

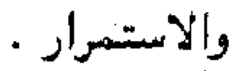

r - التوسع والتنافس بين القنوات للدخول فى شراكة مع الشركات متعددة الجنسبات وفتق

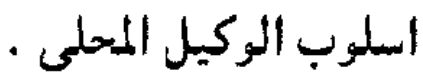

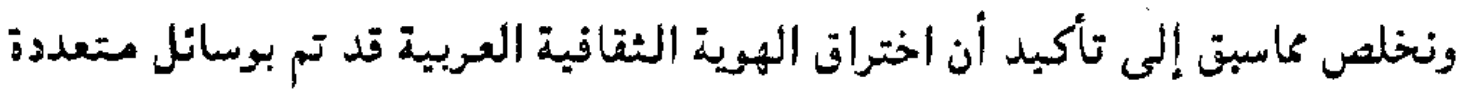

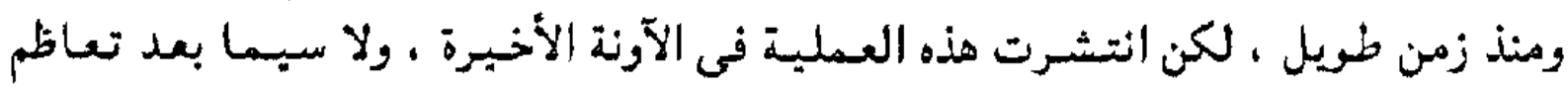

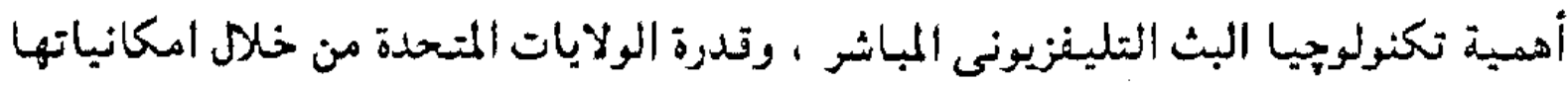

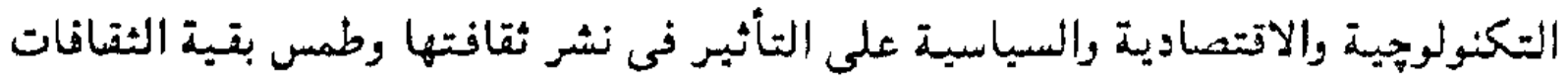

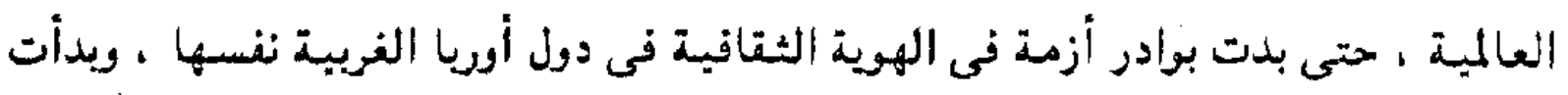

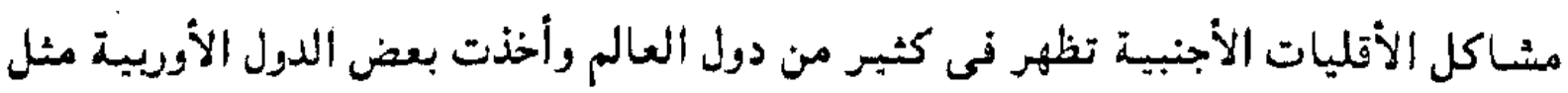

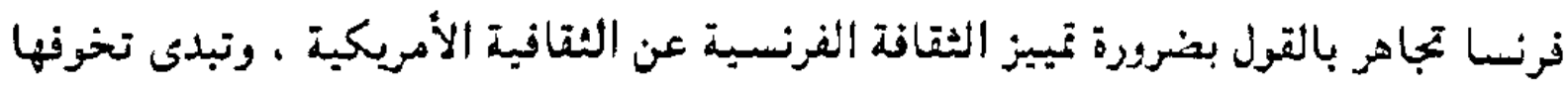

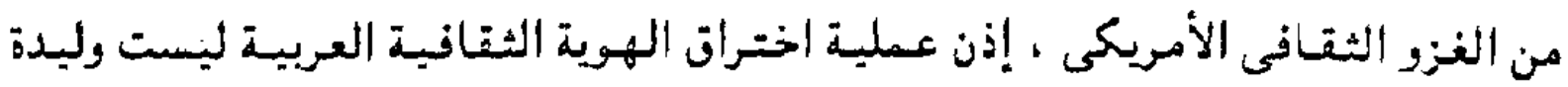


الساعة ، وغير مقصورة عليها ، علاوة على ذلك ساعد البث التليفزيونى المباشر إلى حد كبير فى إتمام عملية الاختراق معير ملفوره

\section{با - تائر البث التليفزيونى المباثر في الموية الثقافية .}

أصبحت وسائل الاعلام تلغب دوراً أساسياً في تشكيل اتجاهات الجماهير والمحانظة

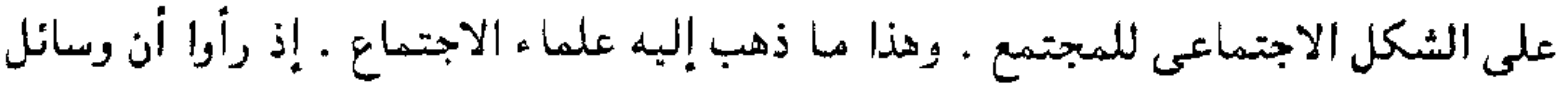

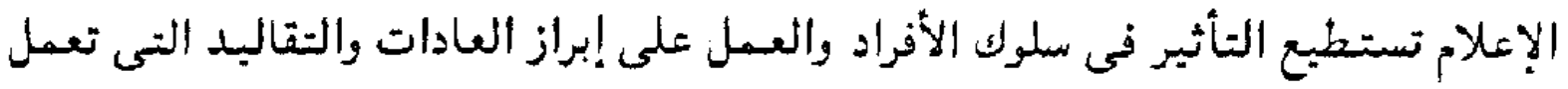

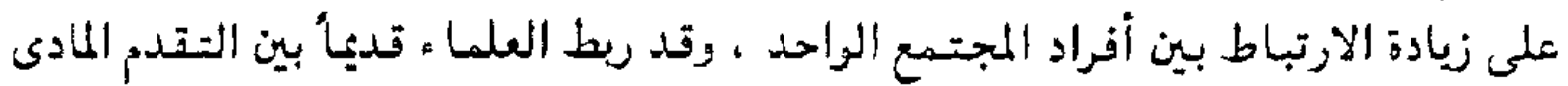

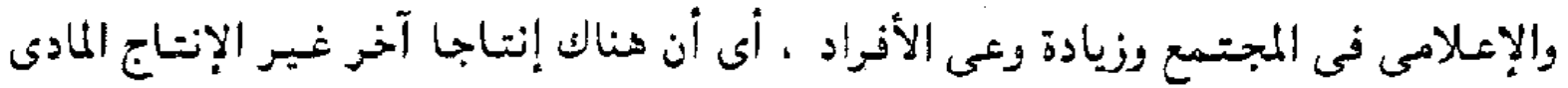

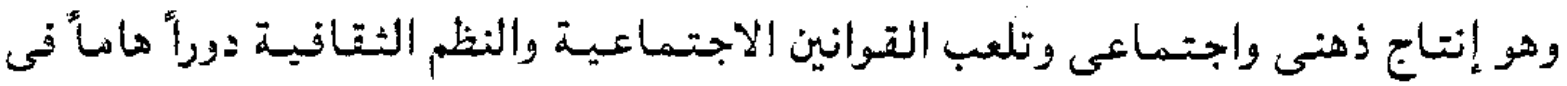

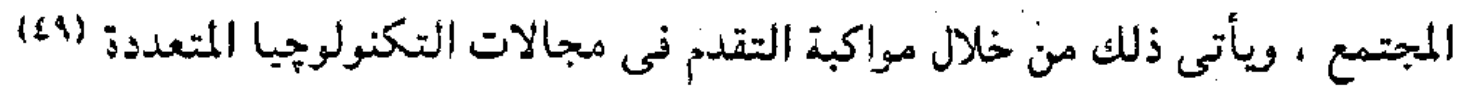
وقد أكد معظم الباحثين أهمية الثقانة وفاعليتها في المجتمع ، وضرورة الاهتمام

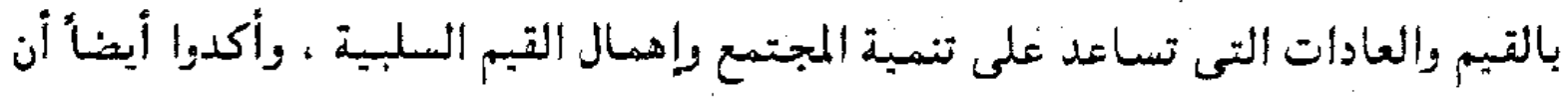

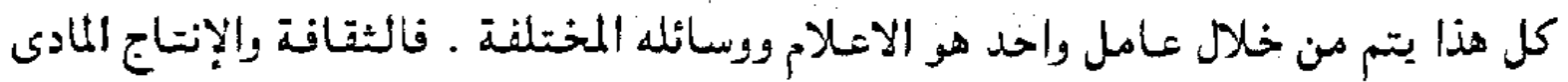

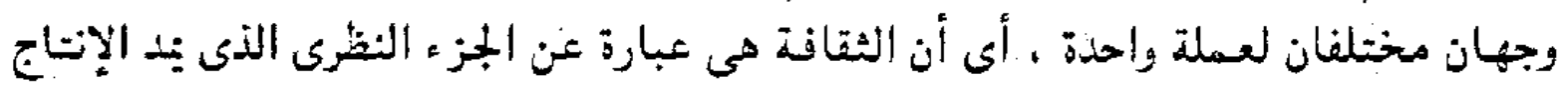

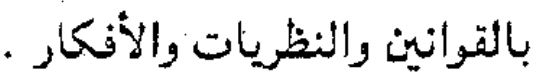

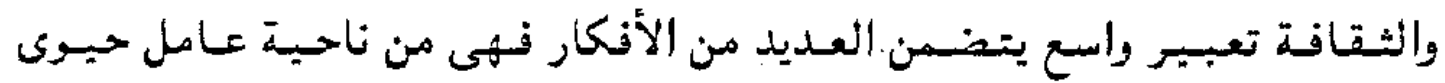

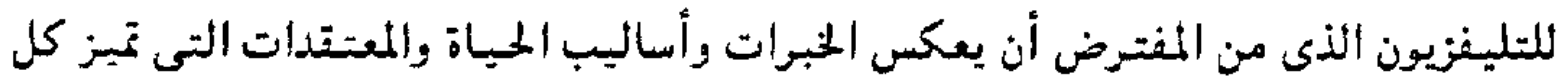

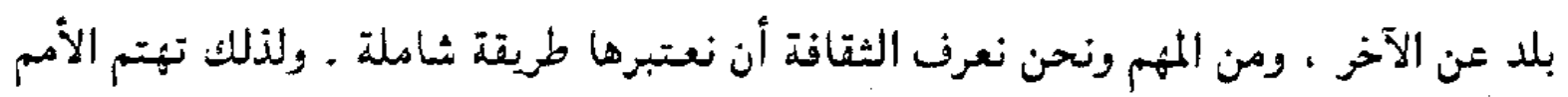

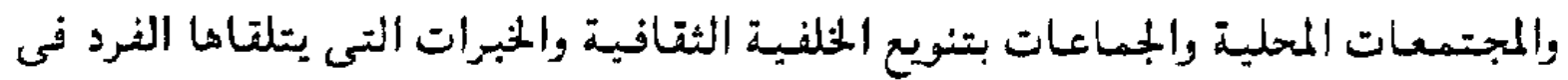

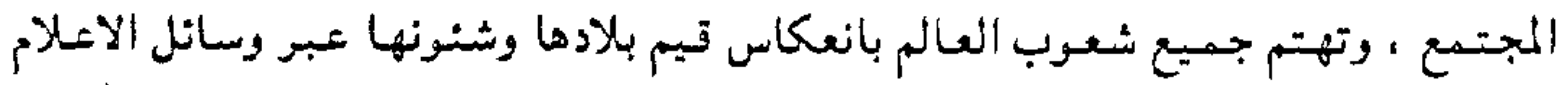

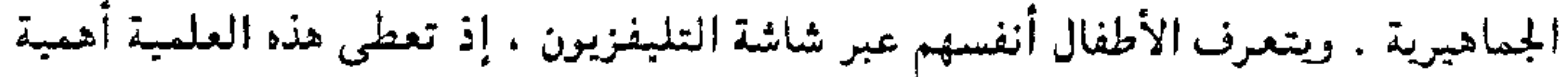

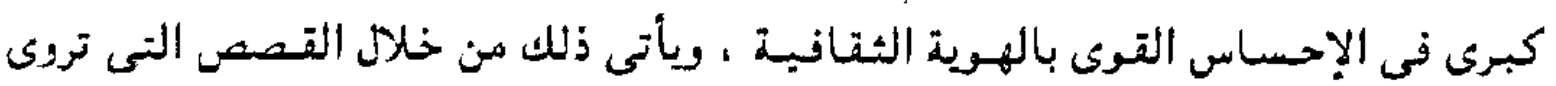
عليهم ، فتعكس صورتهم عبر التليفزيون . ويستطيع المجتمع المحلى أن يشجبع الأطفال

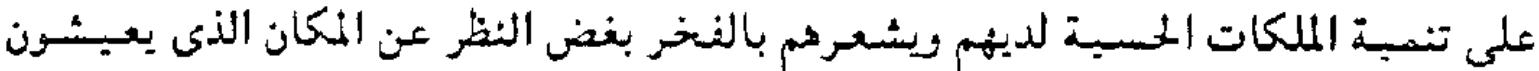

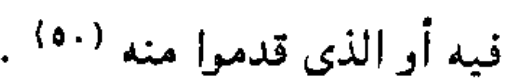

وفى عصر التليفزيون المتعدد التنوات ـ انتشرت خدمات الكابل والقمر الصناعى الماتى عبر الكرة الأرضية ، ويتنافس المذيعون فى المحطات العامة دع مذيعى المحطات التجارية ، 


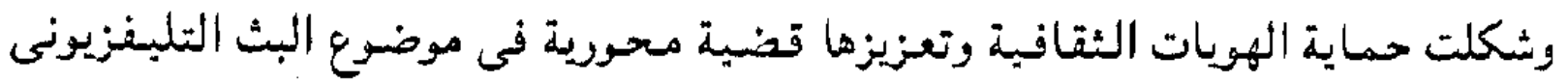

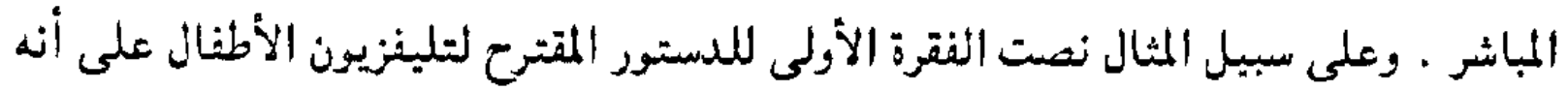

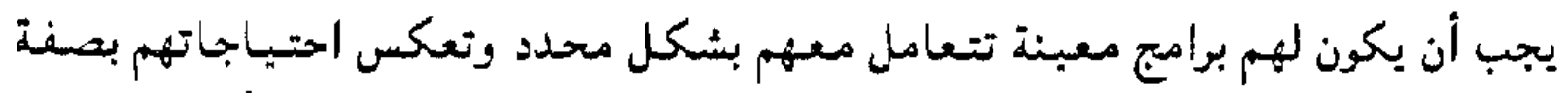

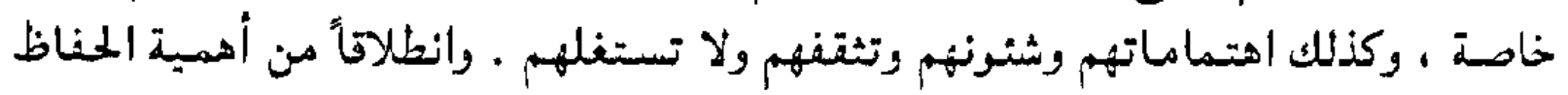

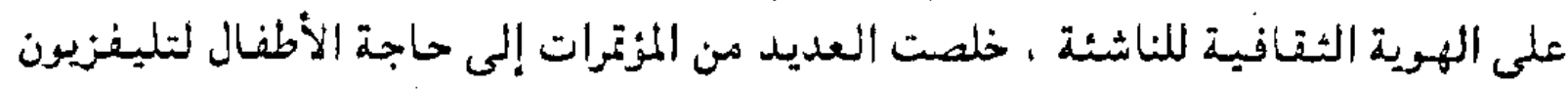

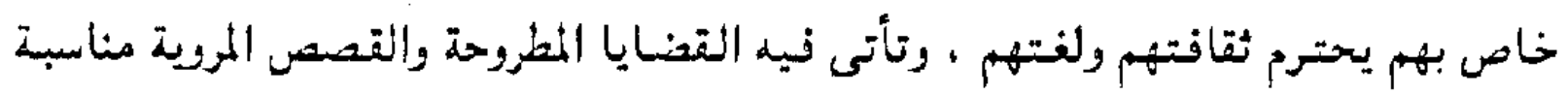

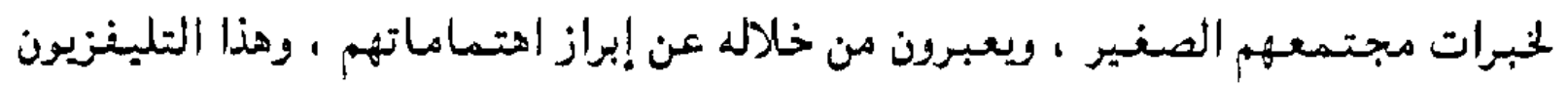

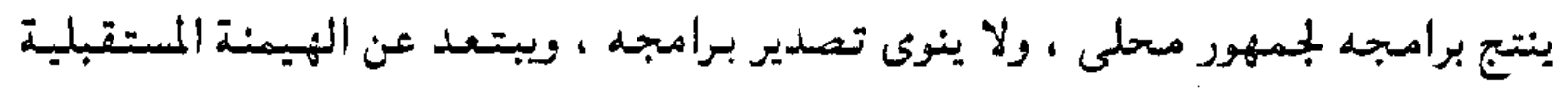

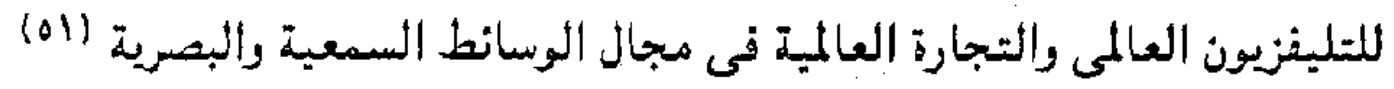
وإذا حاولنا التعرف على تأثير البث الثليفزيونى المباشر في الهية الثية الثقافية العريبة.

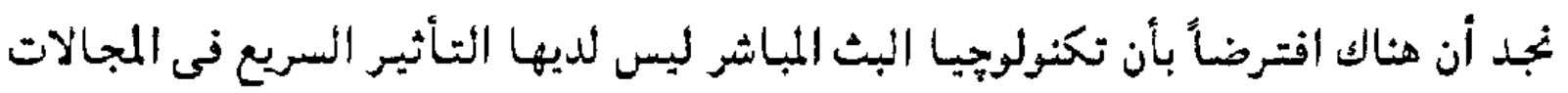

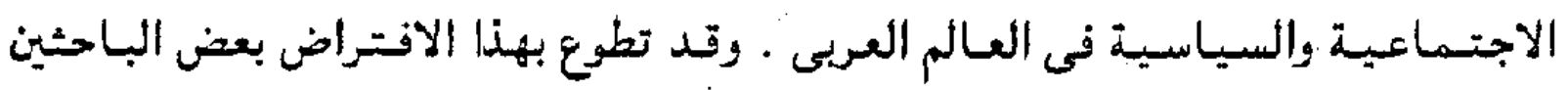

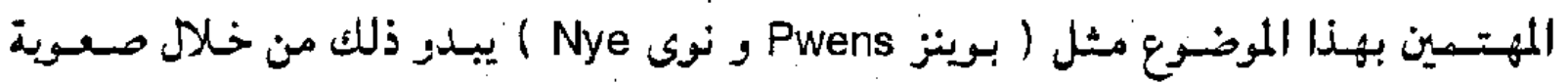

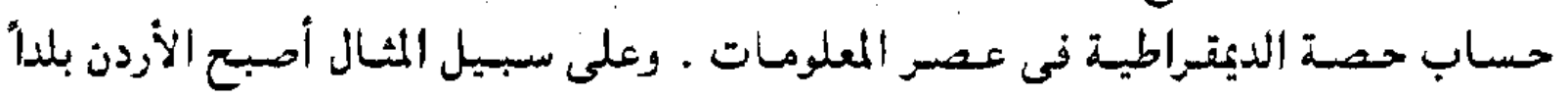

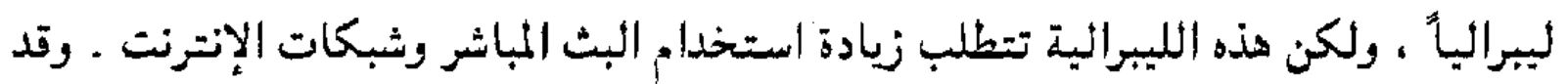

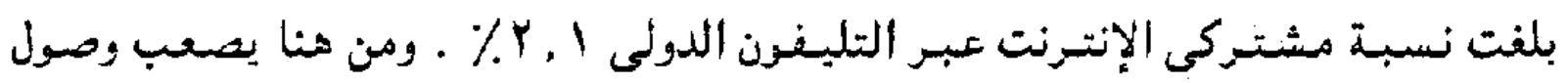

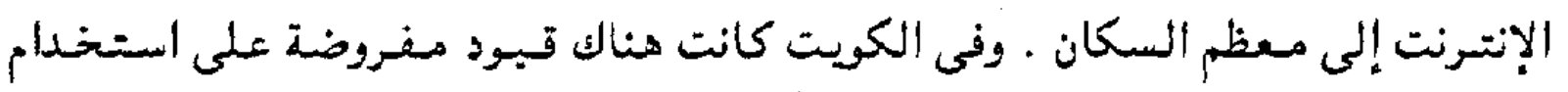

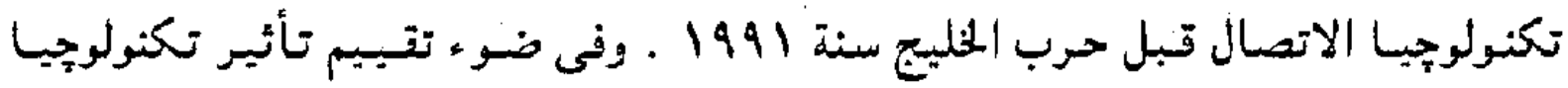

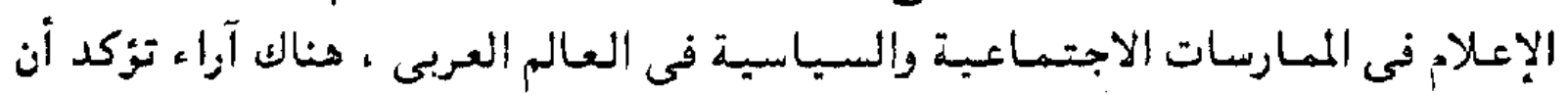

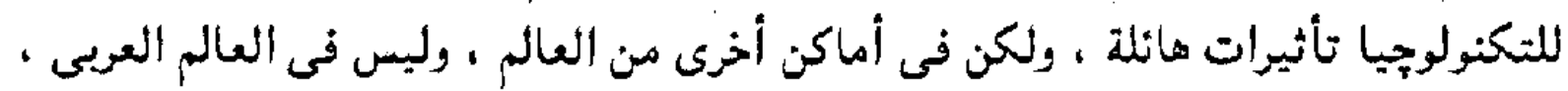

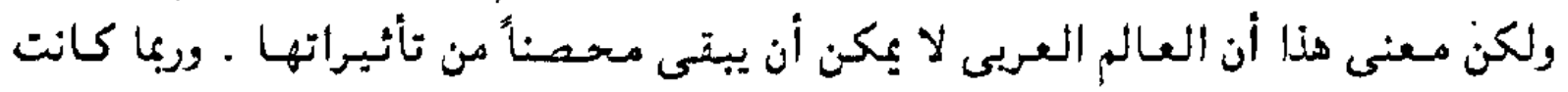

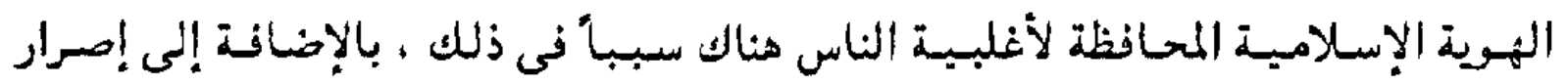

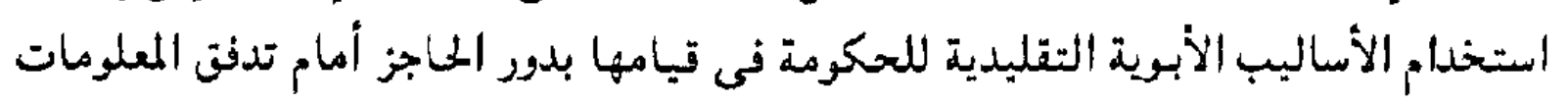

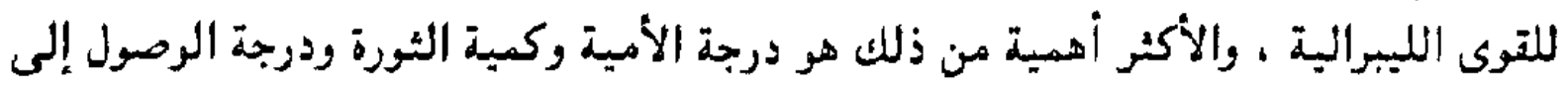

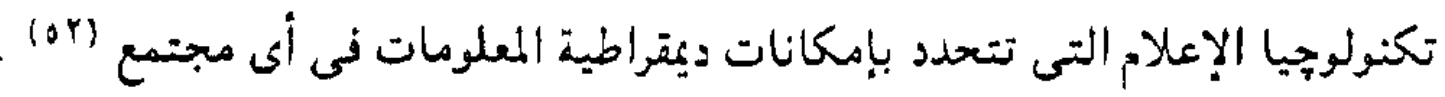

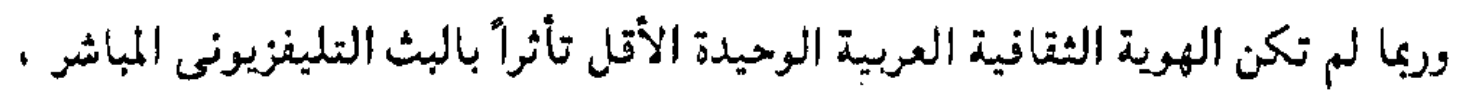

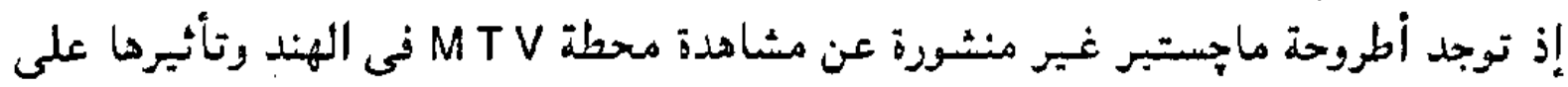

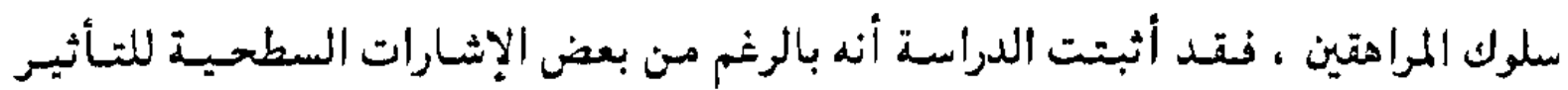




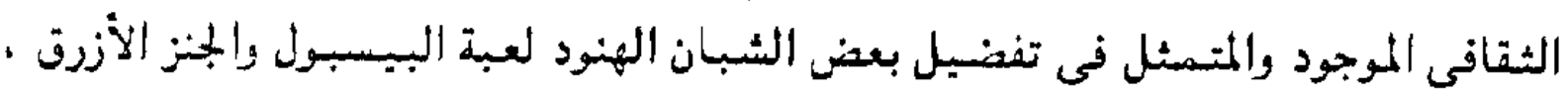

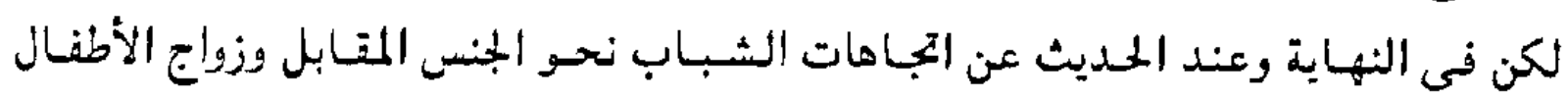

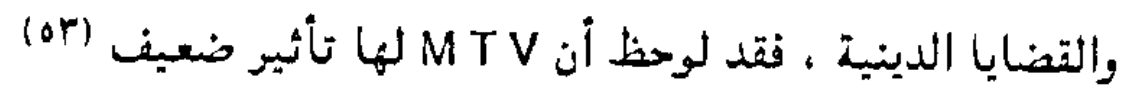

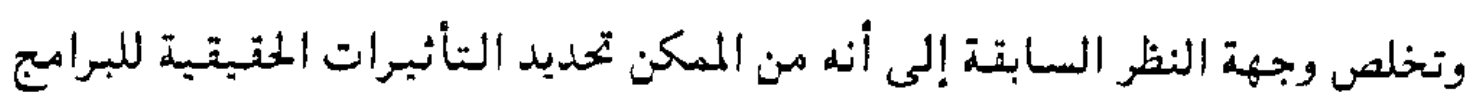

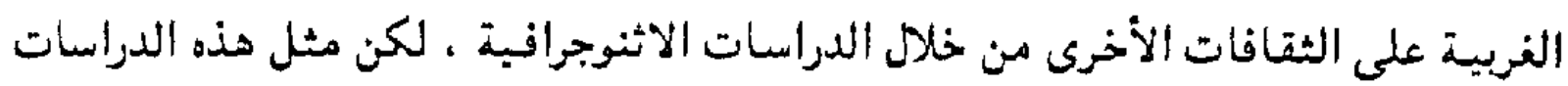

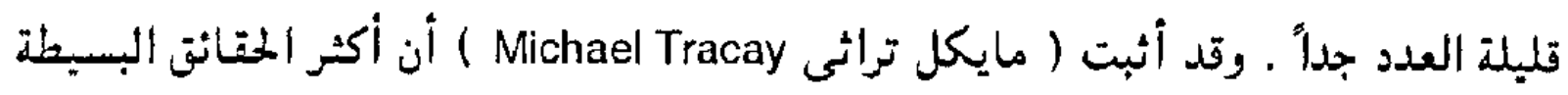

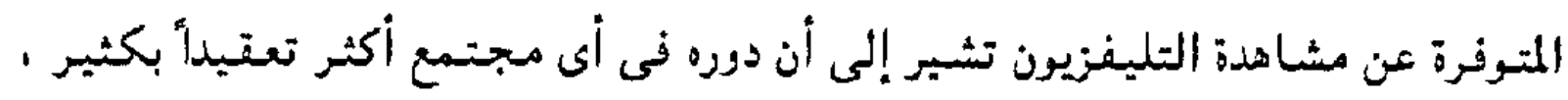

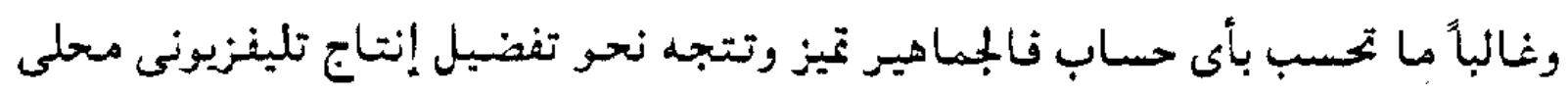

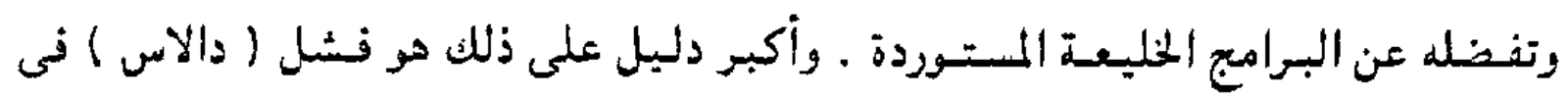

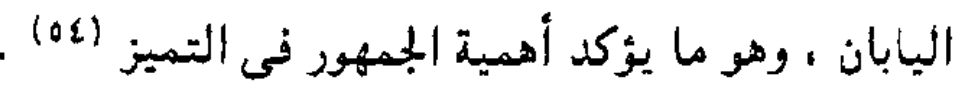

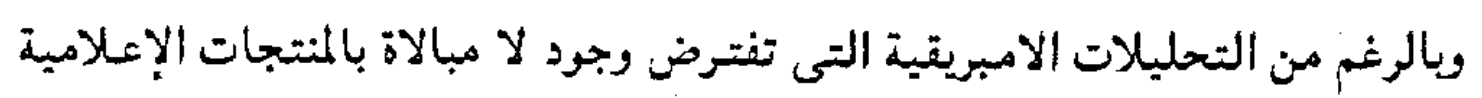

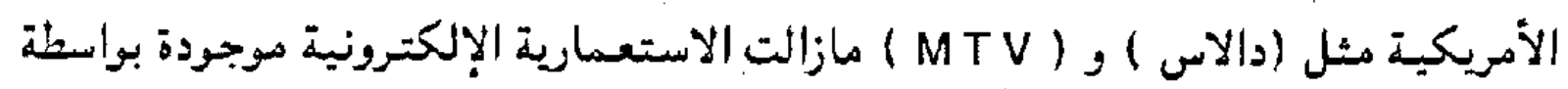

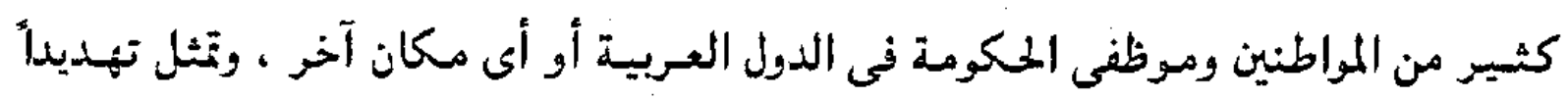

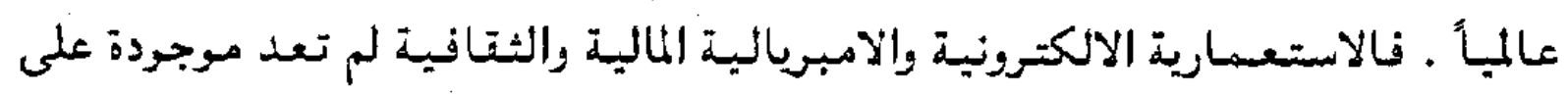

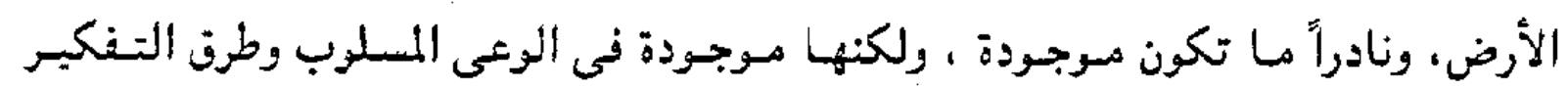

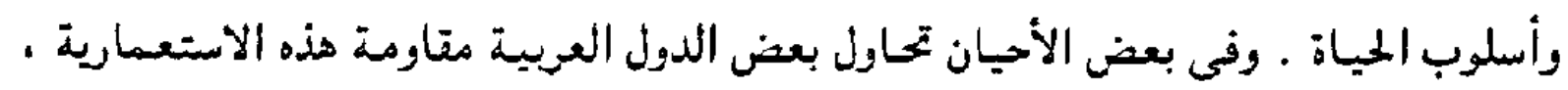

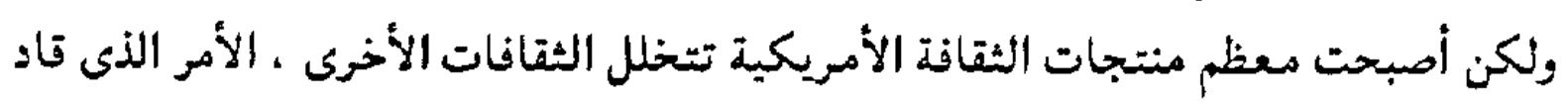

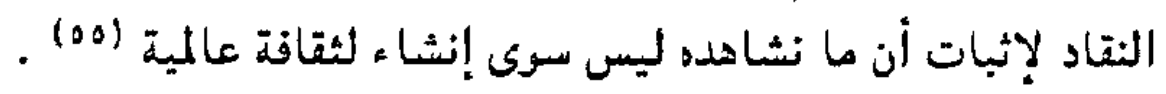

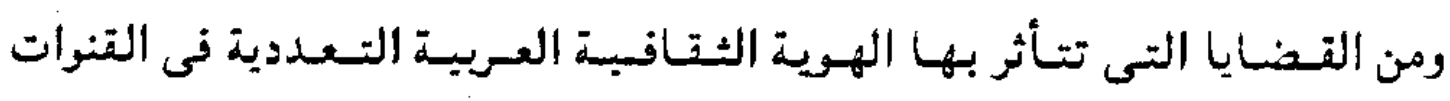

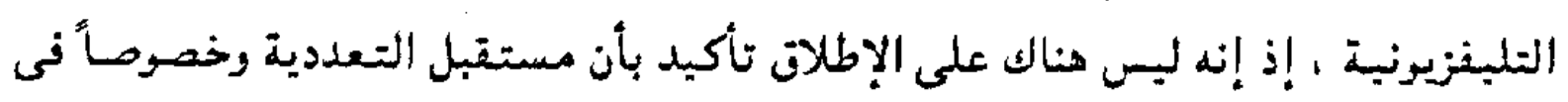

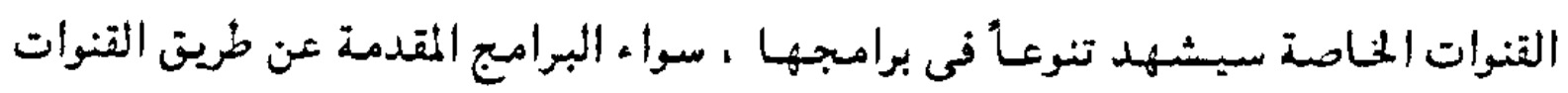

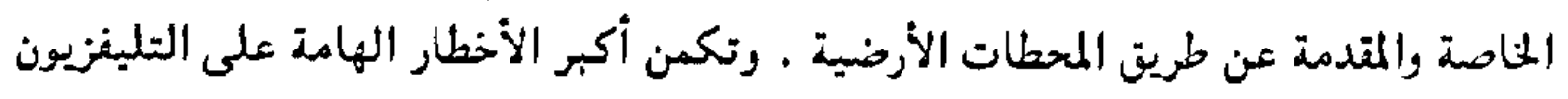

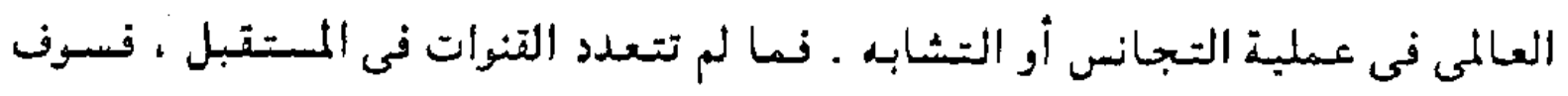

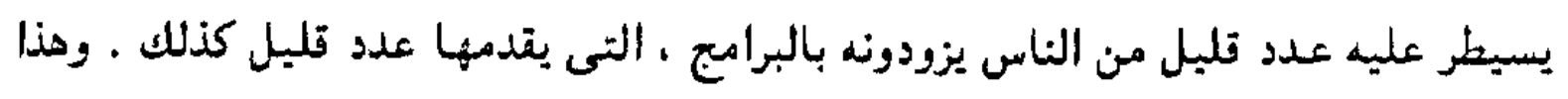

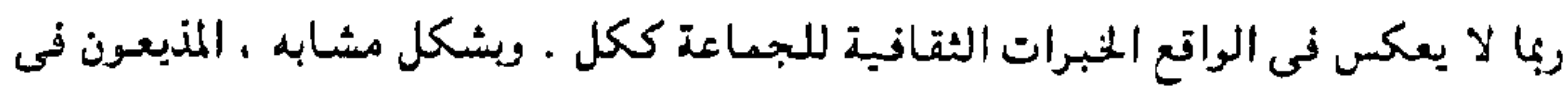

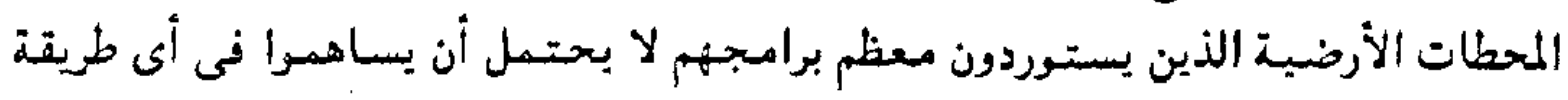

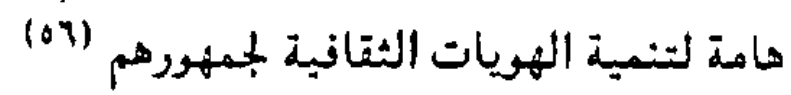




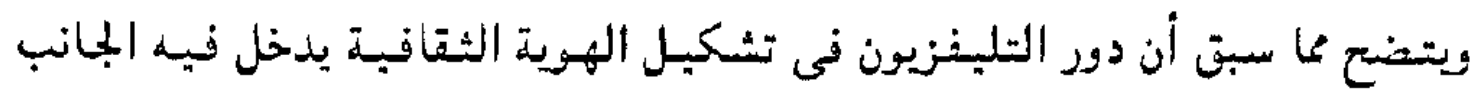

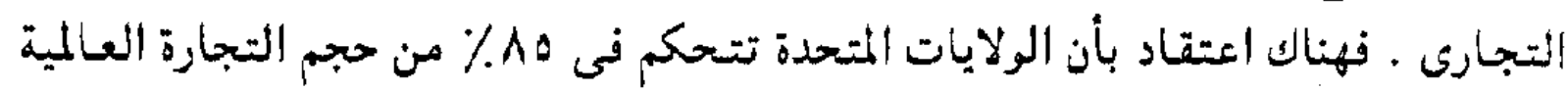

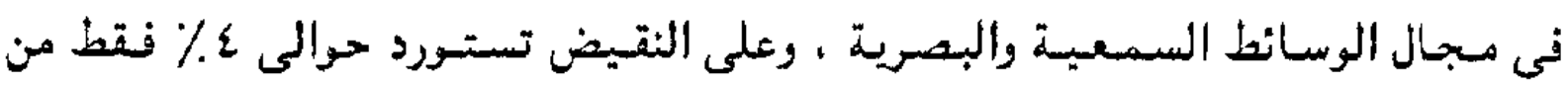

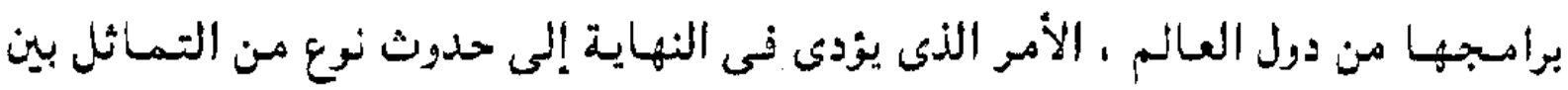

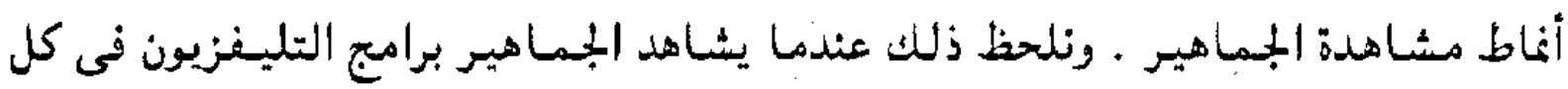

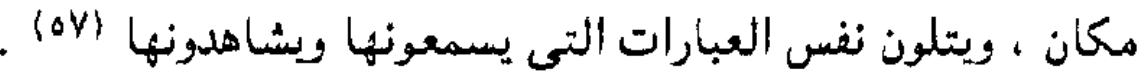

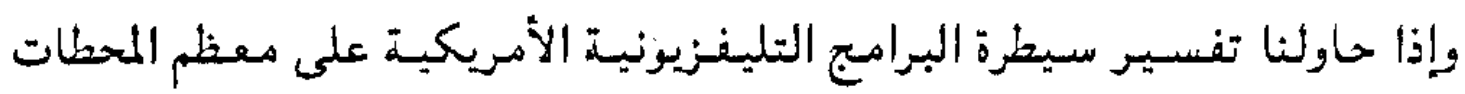

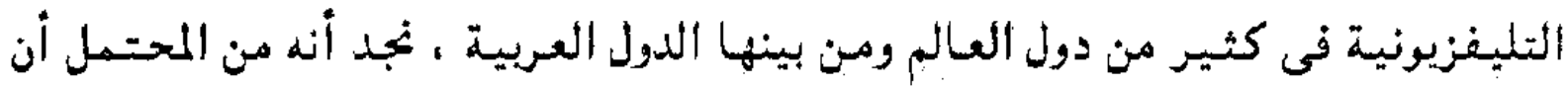

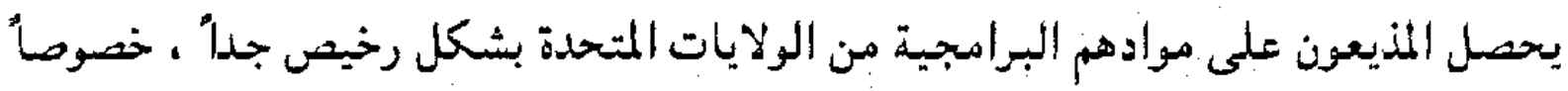

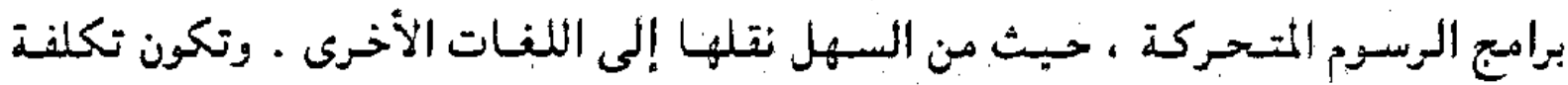

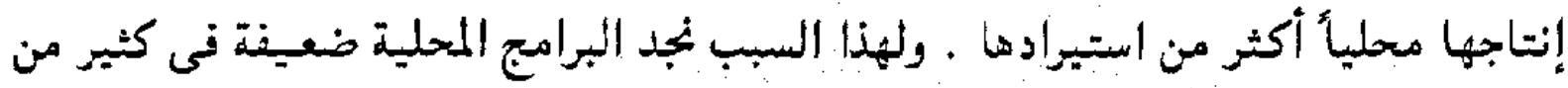

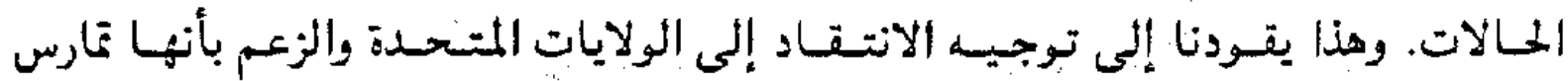

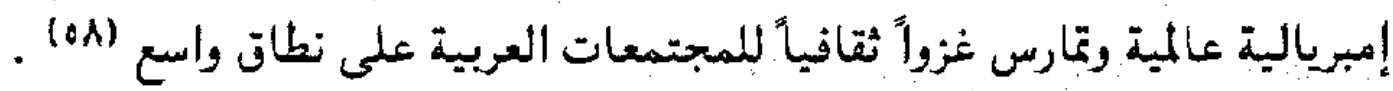

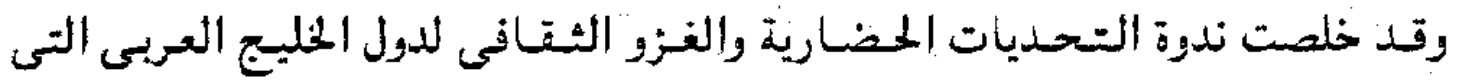

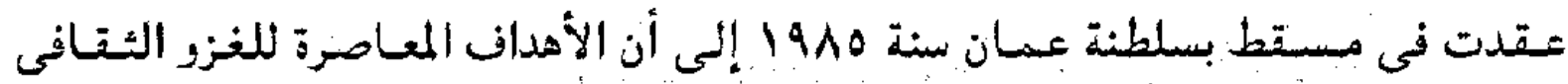

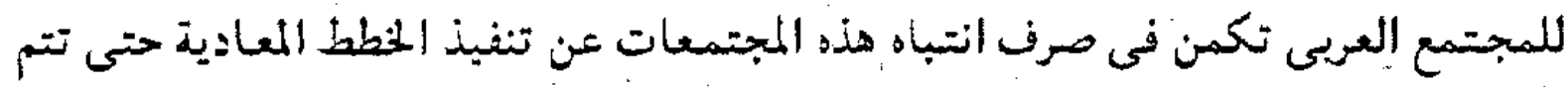

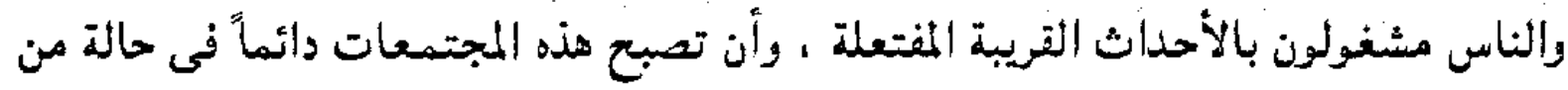

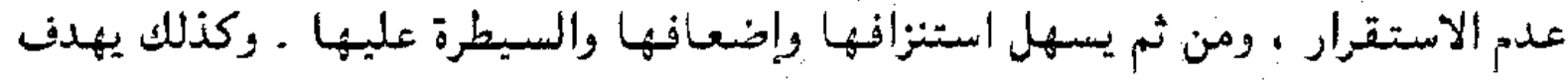

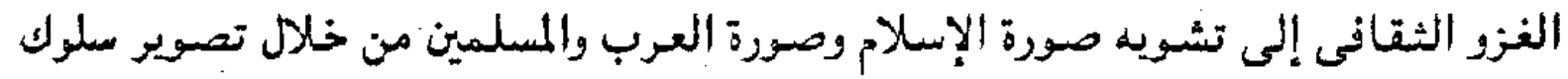

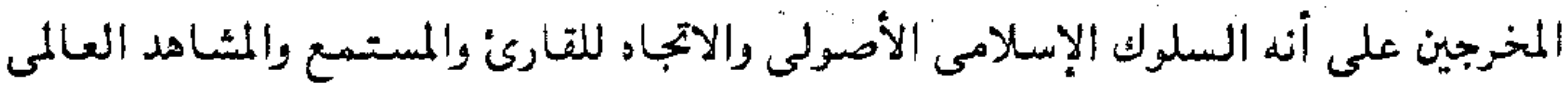

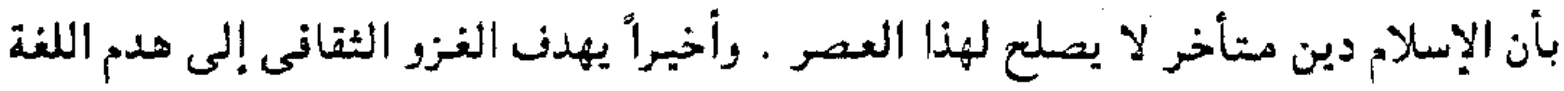

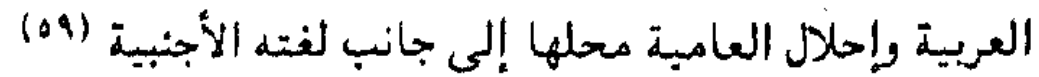

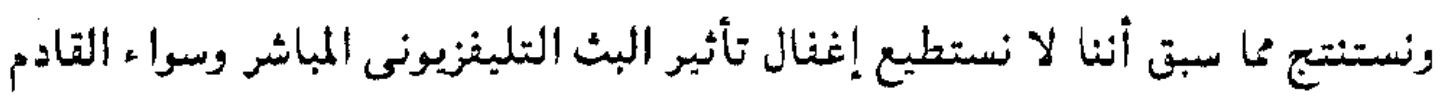

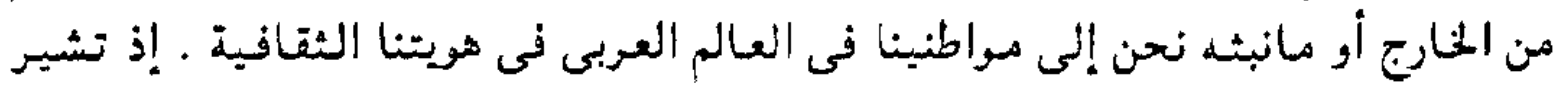

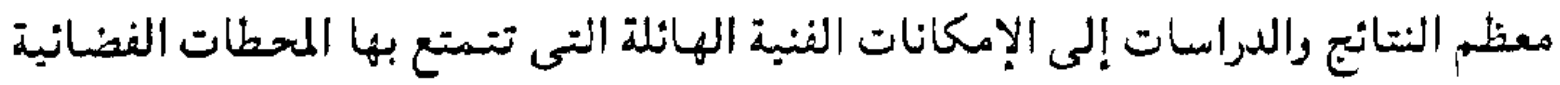

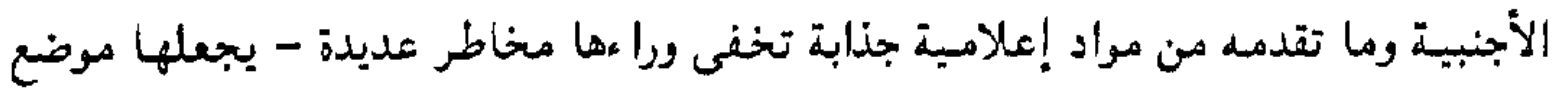

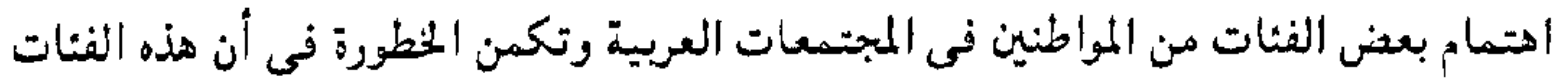

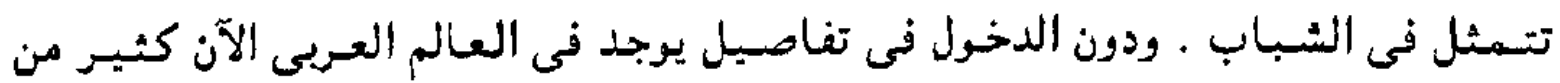




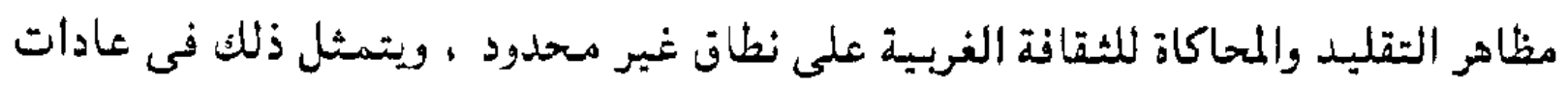

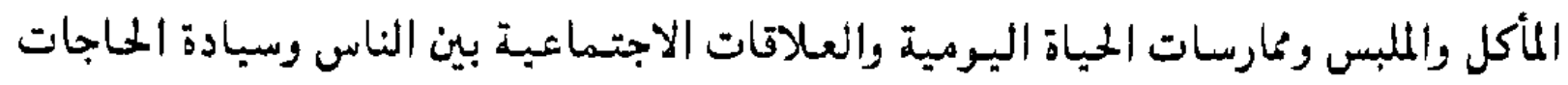

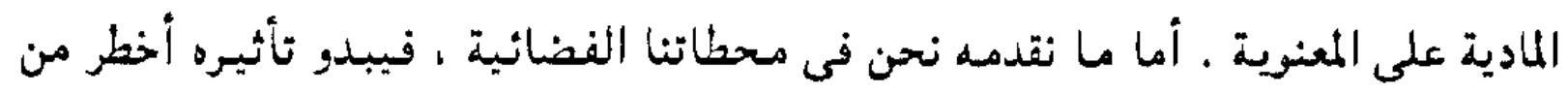

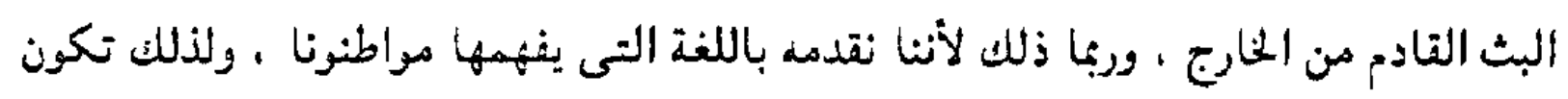

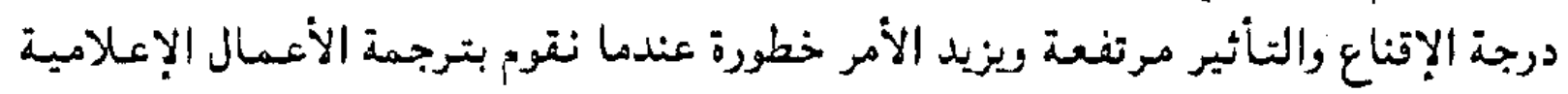

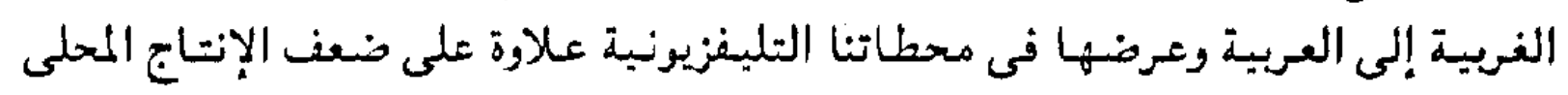
فى مجال البرامج والمسلسلات والأفلام .

وبالرغم من المخاطر العديدة للبث التليفزيونى المباشر ، تبقى حقيقة هامة وهى أنه النه

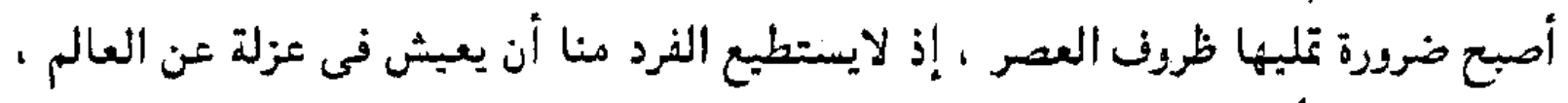

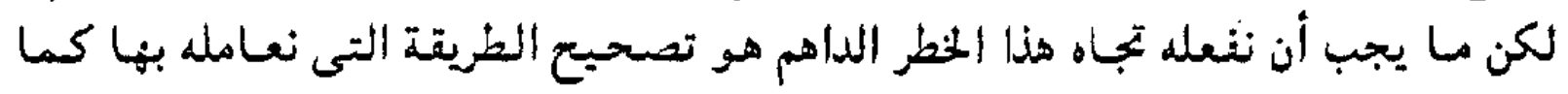

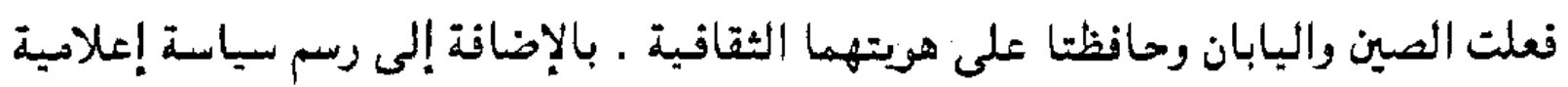

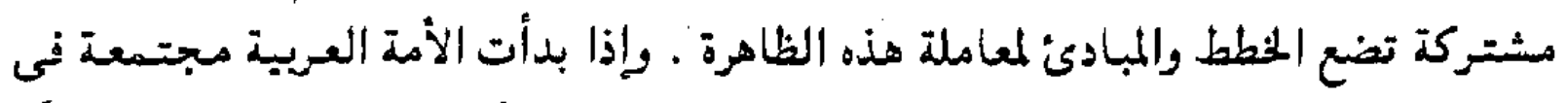

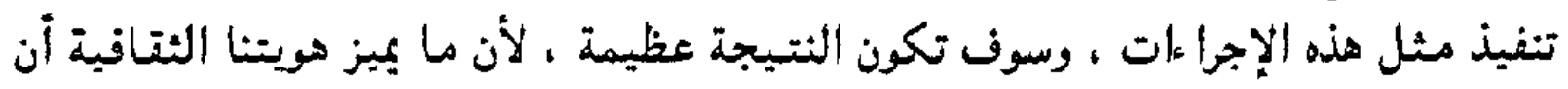

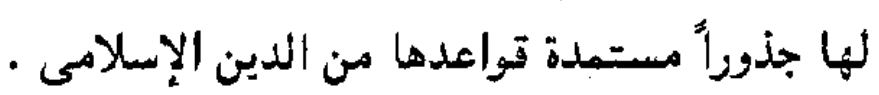

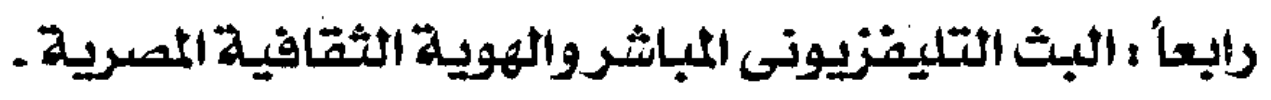

تميزت الهوية المصرية بأنها نشأت منذ آلاف السنين ، وامتدت متنامية عبر الزمان

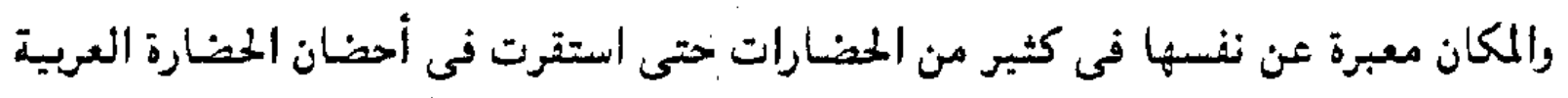

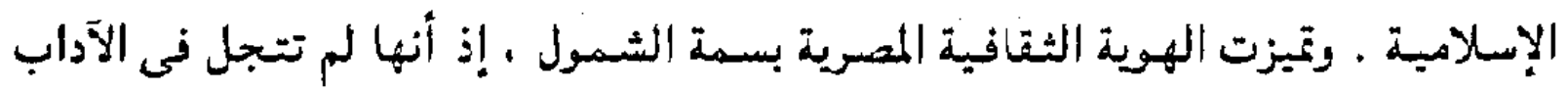

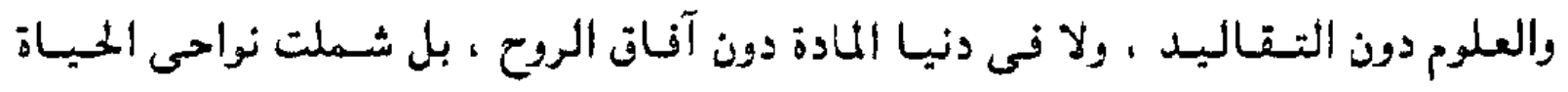

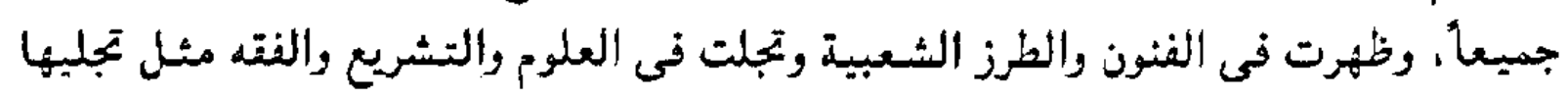

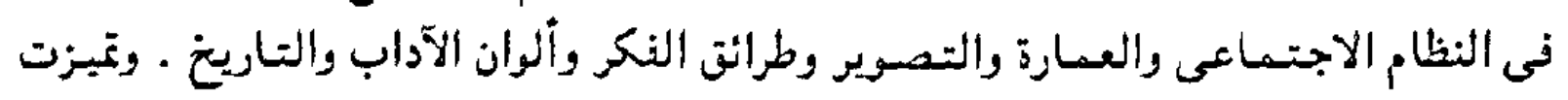

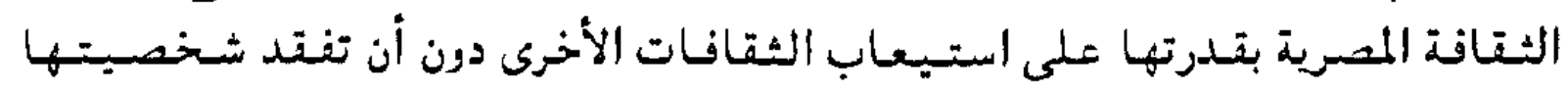

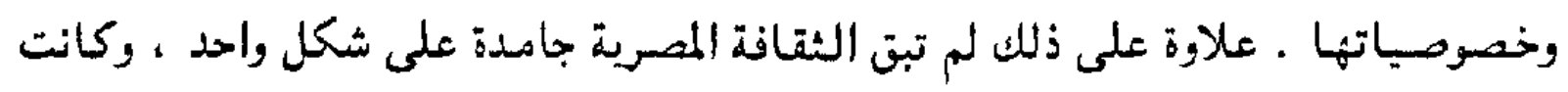

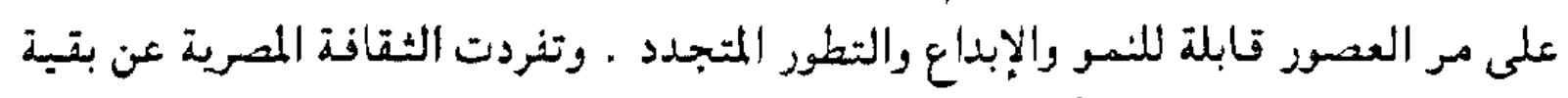

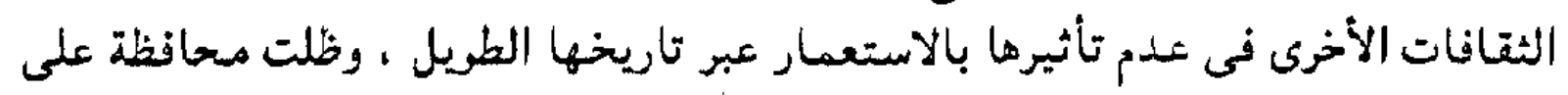

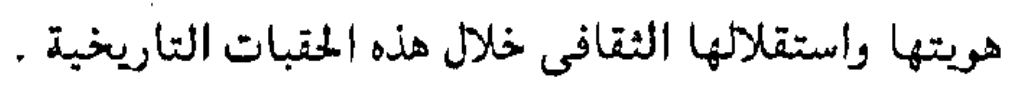

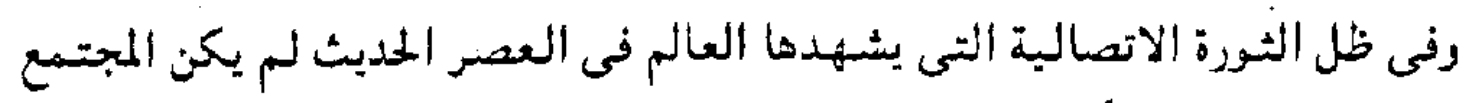

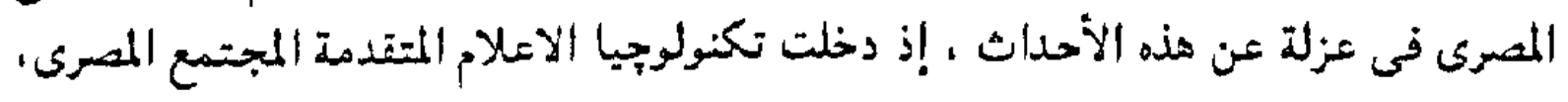


وانتشرت ظاهرة الأطباق الهوانية فوق اسطح المنازل ، وبدت نسبة ليست قليلة من المواطنين

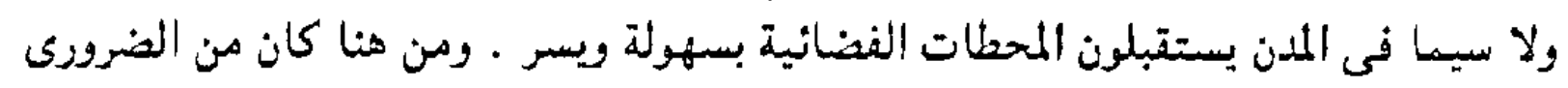

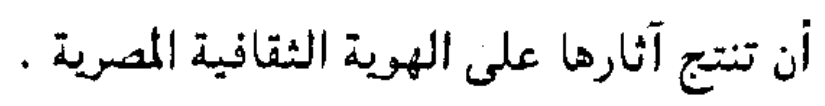

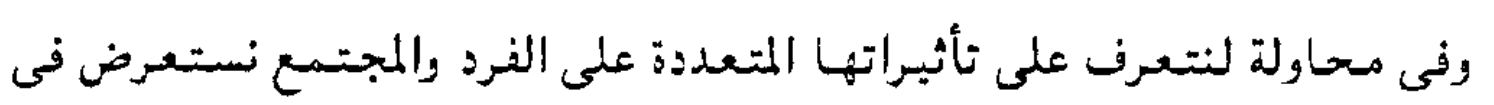

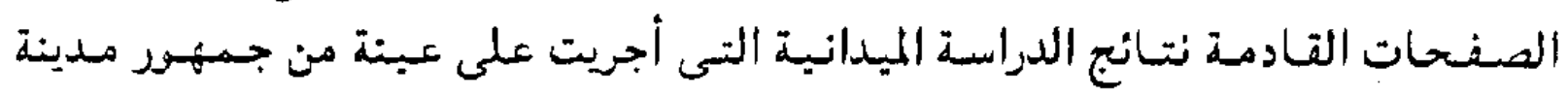

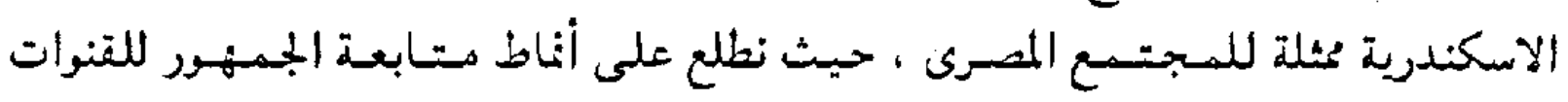

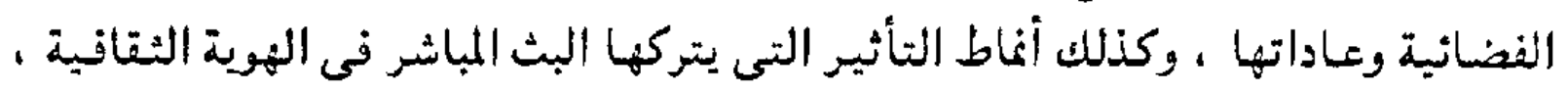

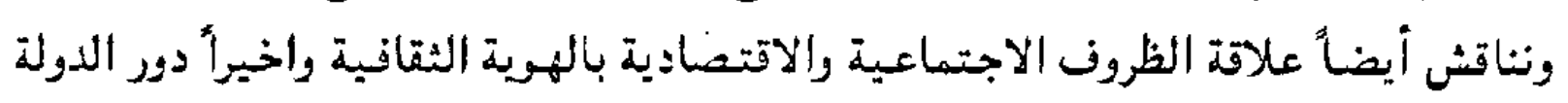

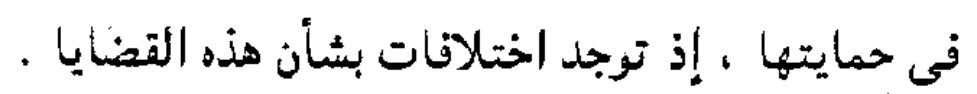

\section{وفيما يلى تتائج الدواستة الميدانية :}

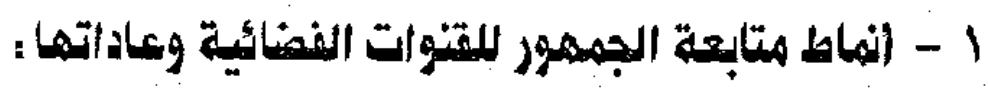

( أ ) أوضحت نتائج الدراسة بشأن علاقة المبحوثين بمتابعة قنوات الدش أن معظم أفراء

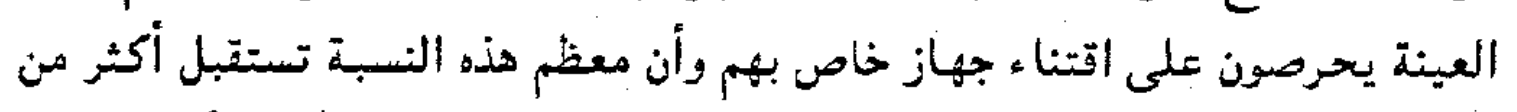

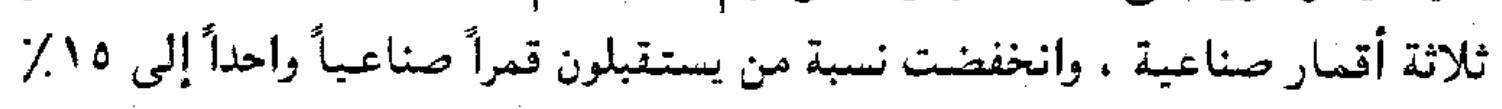

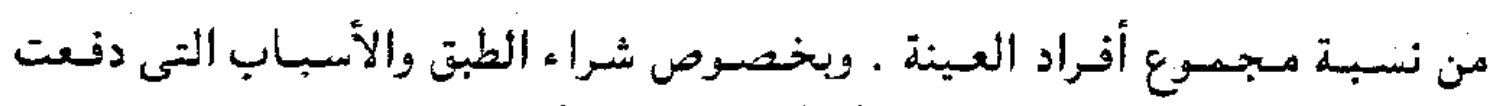

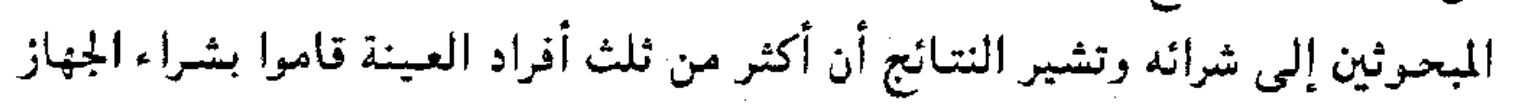

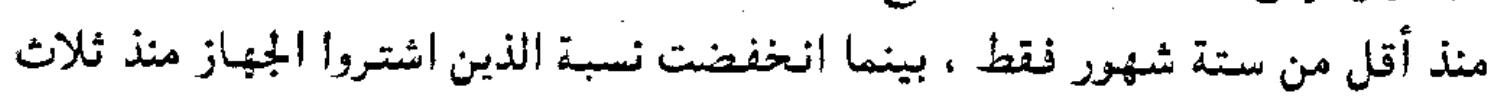

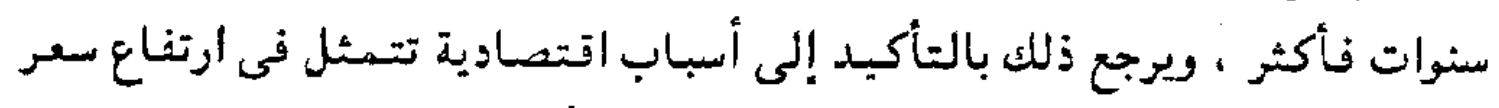

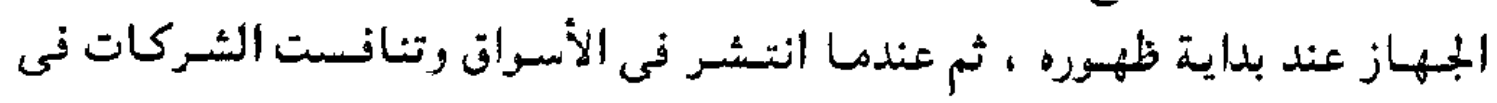

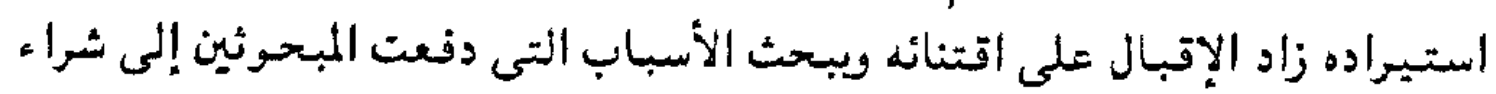

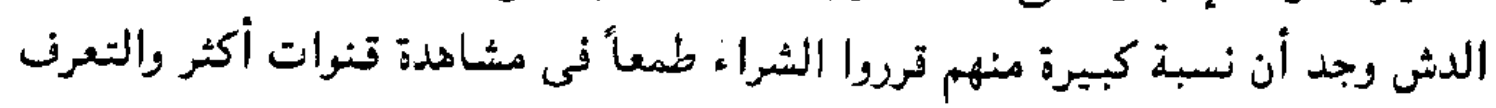

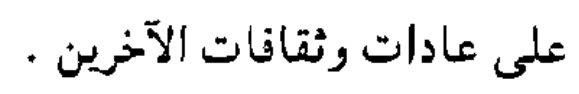

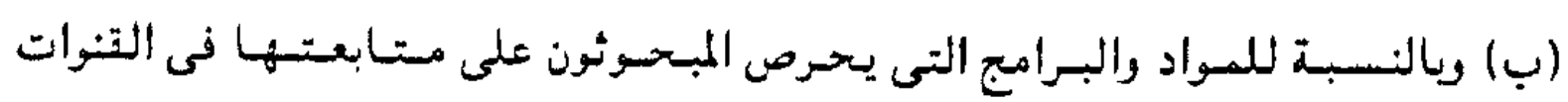

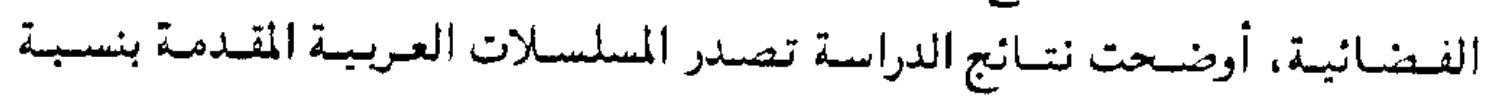

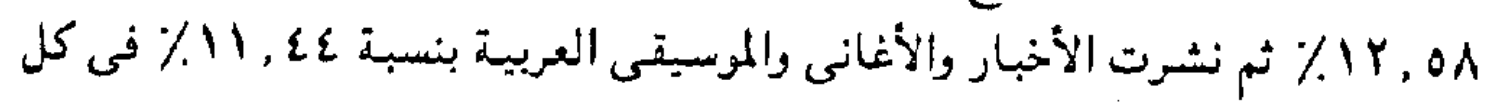

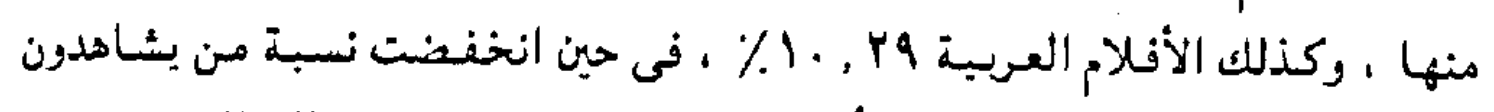

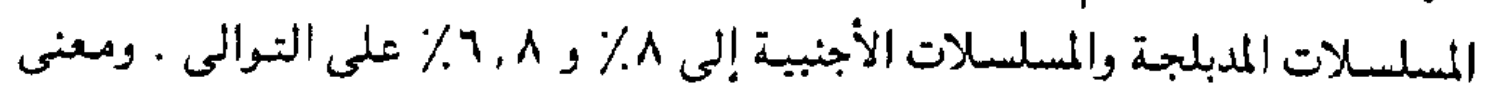


هذا أن المسلسلات العربية وكذلك البرامج تمثل عاملاً رئيسـياً في متابعة الجمهيور

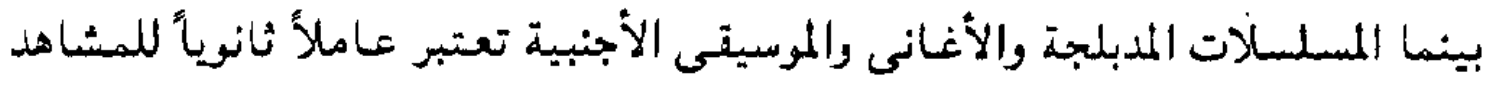

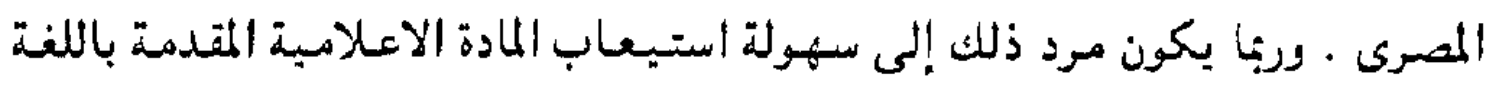

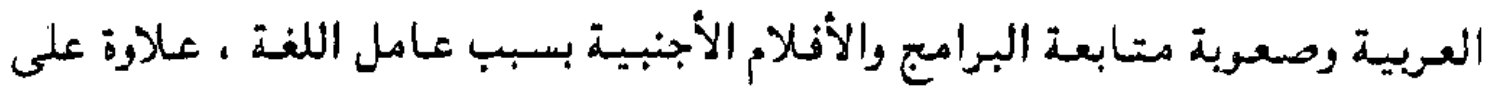
اخجيلاف الموضوعات والتضايا التى تتناولها البرامة والأفلام العبية والأجنبية .

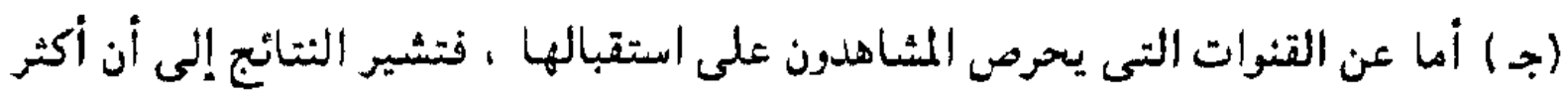

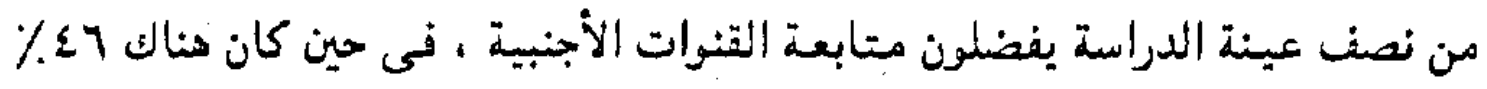

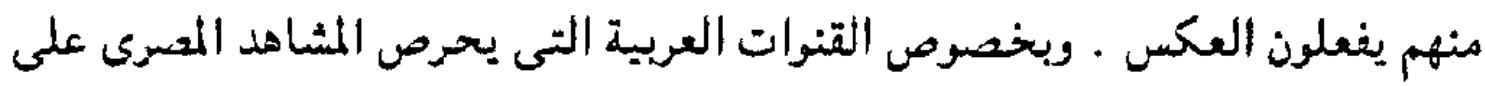

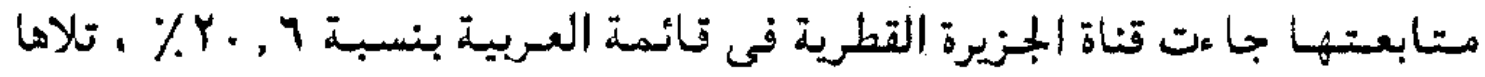

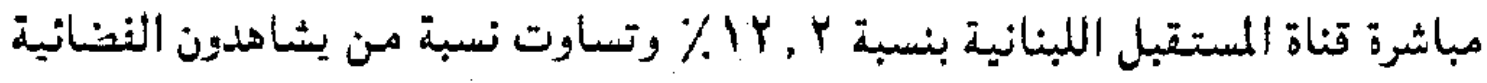

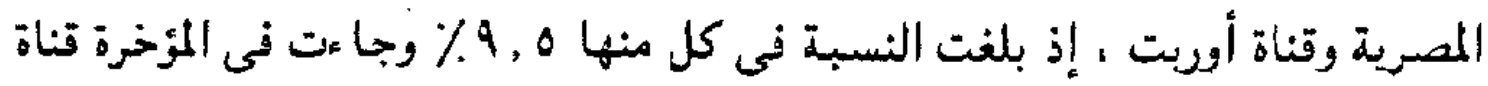
M B C

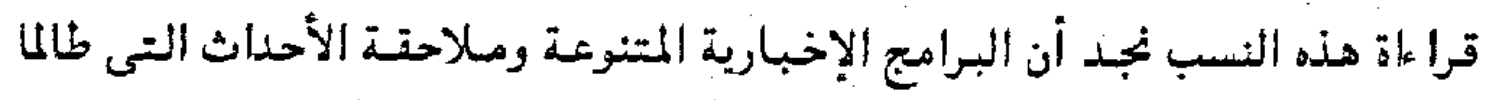

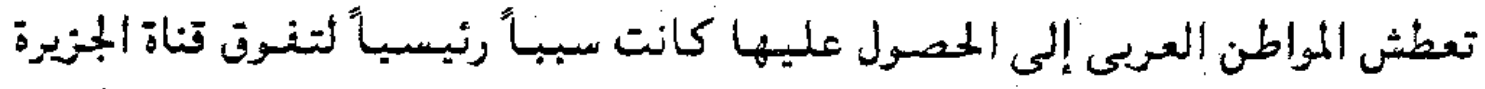

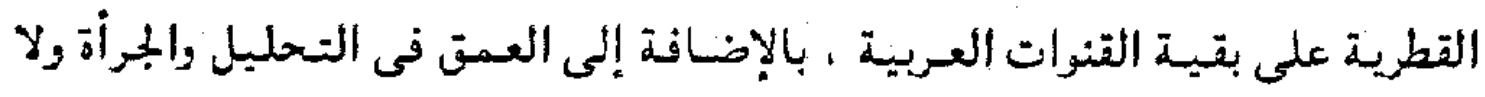

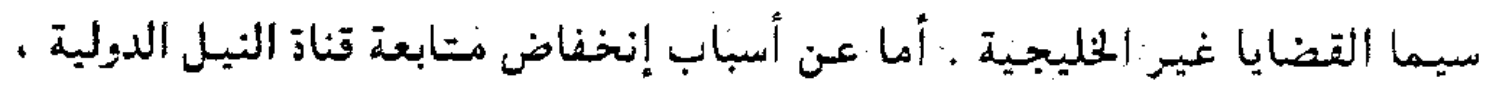

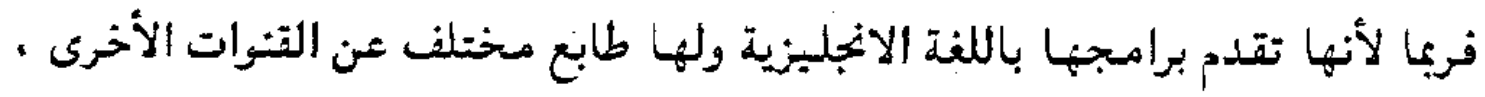

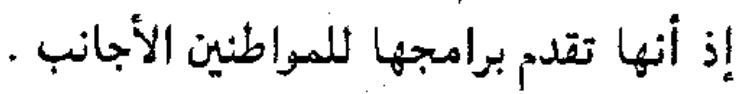

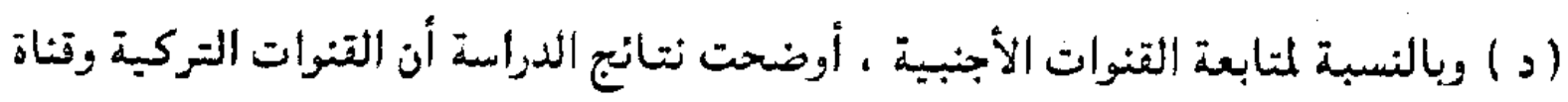

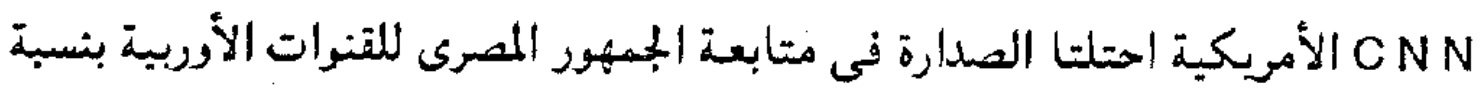

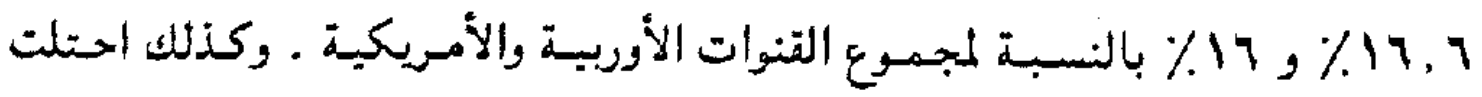

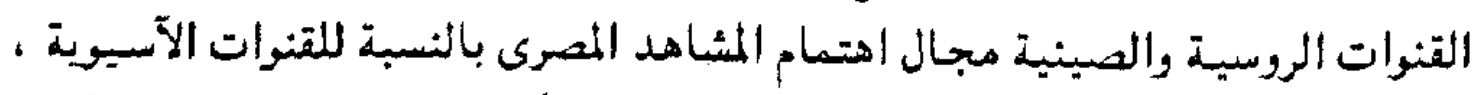

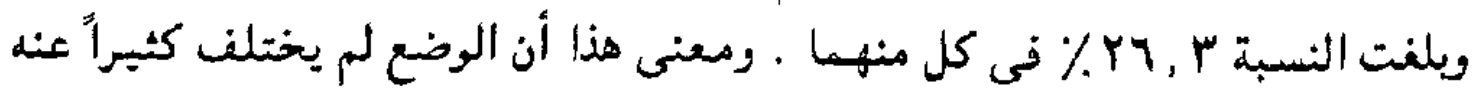

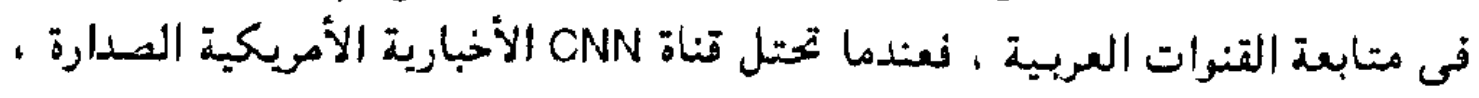

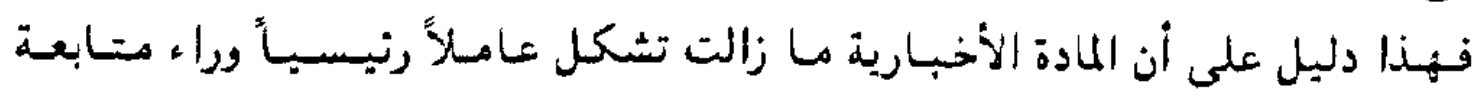
الجمهور للقتاة التليفزيونية .

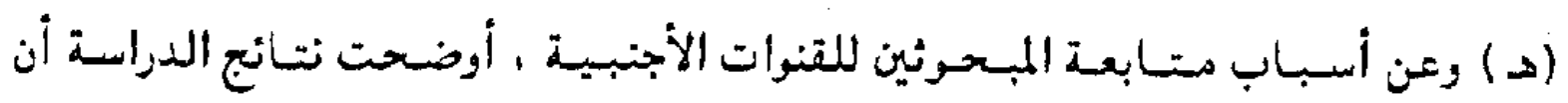

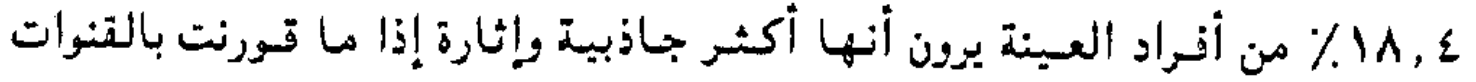


العربية ، علاوة على أنها تتسم بالجرأة فى تناول الموضوعات وبتميز العاملون فيها

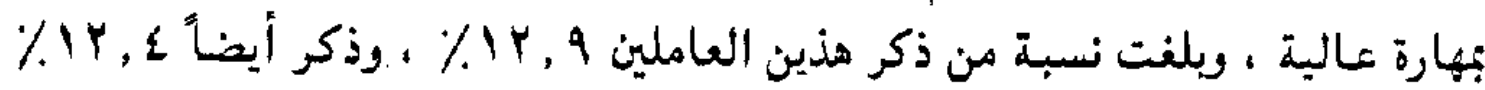

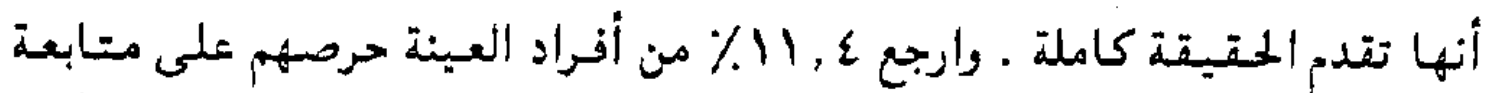

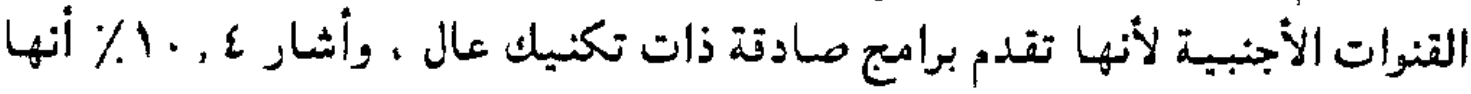

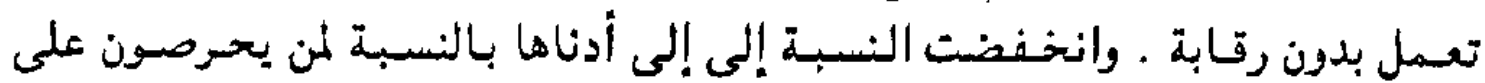

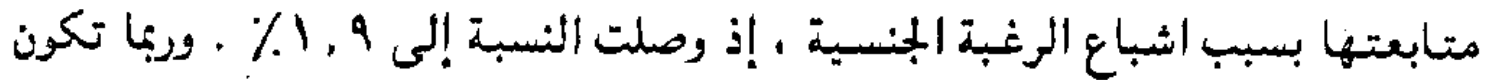

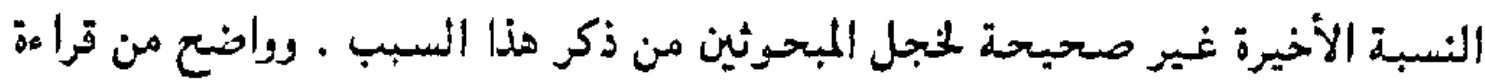

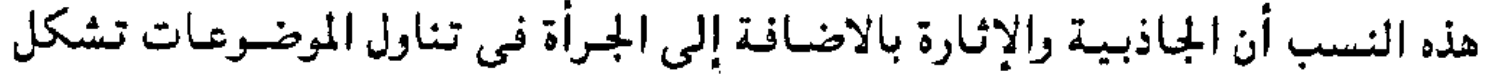

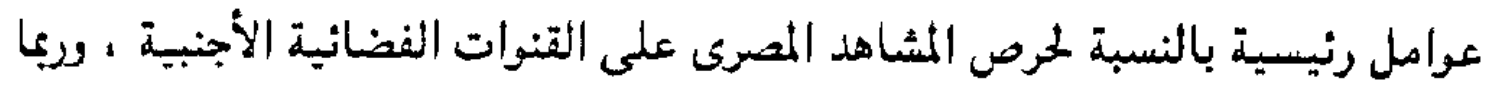
تكون هذه الأسباب مفتقدة في القنوات العربية .

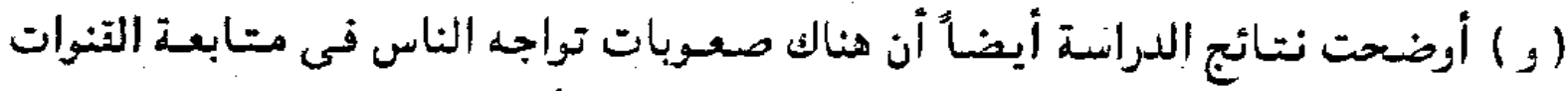

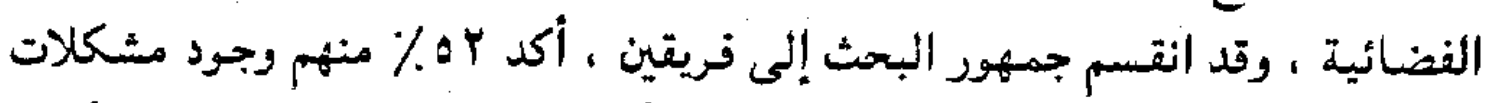

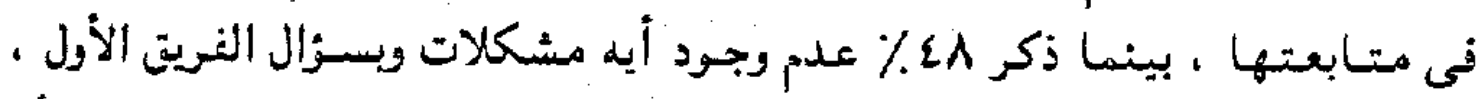

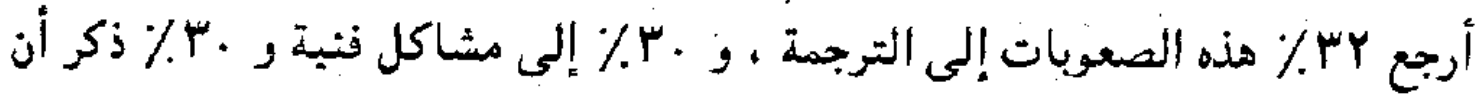

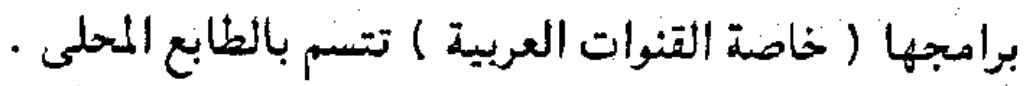
r - اتجاهات الجماهير نحمو البث التلينزيونى المباشثر :

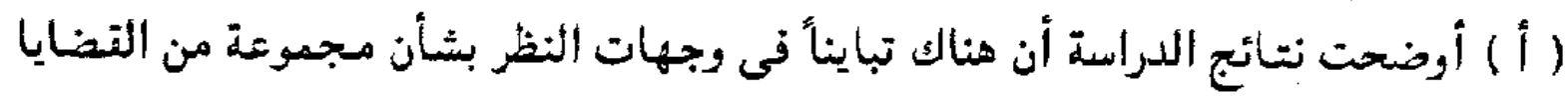

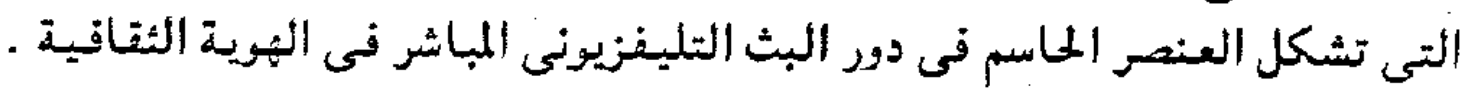

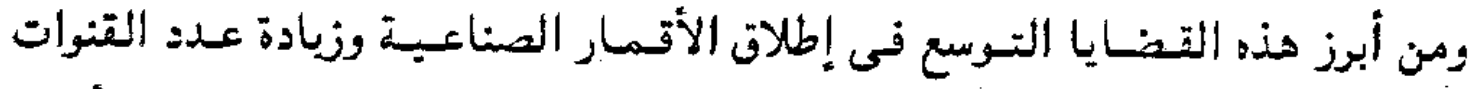

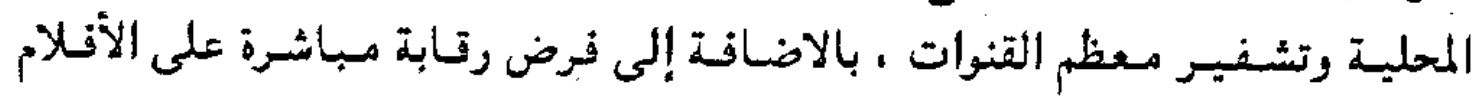

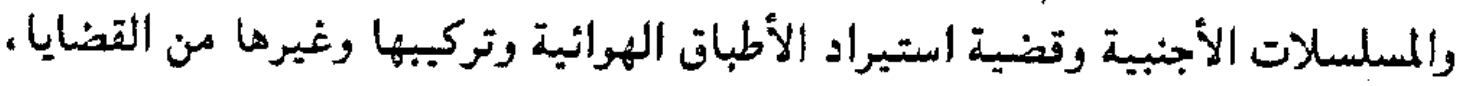

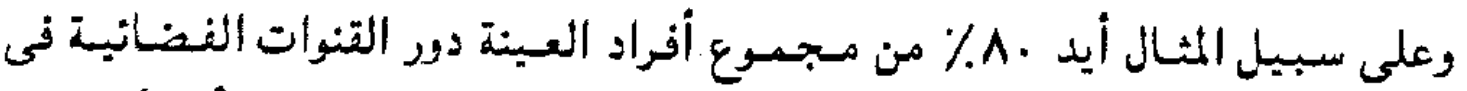

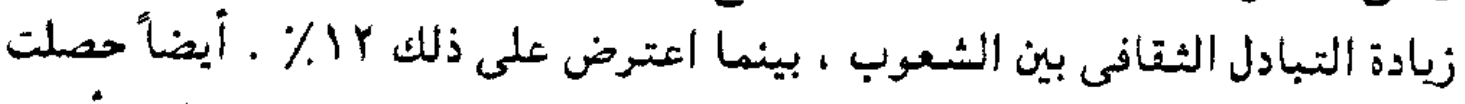

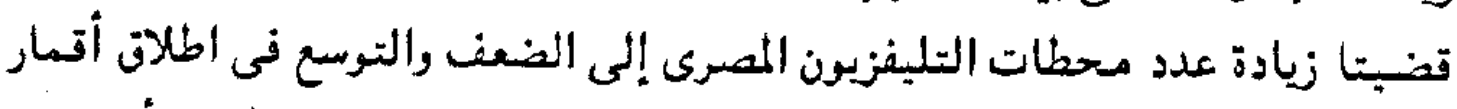

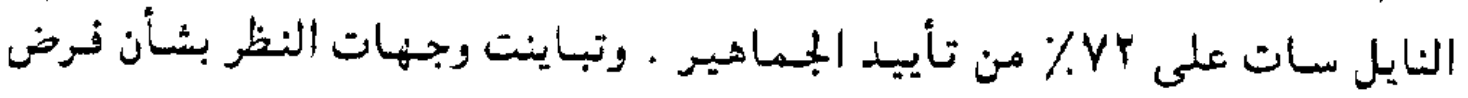

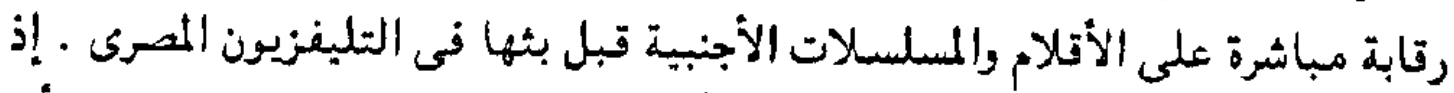

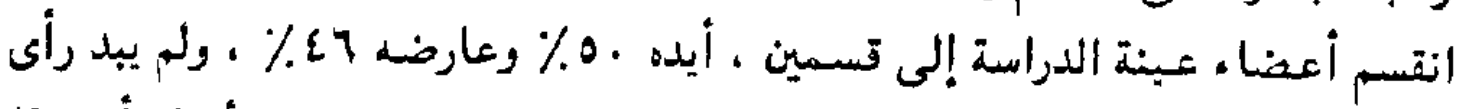

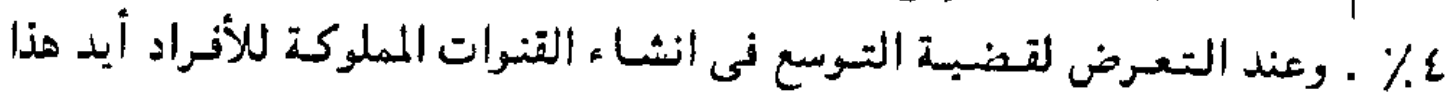

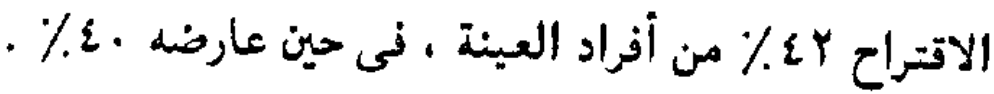




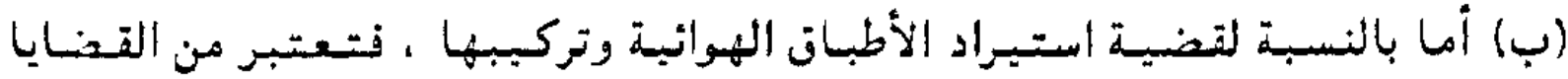

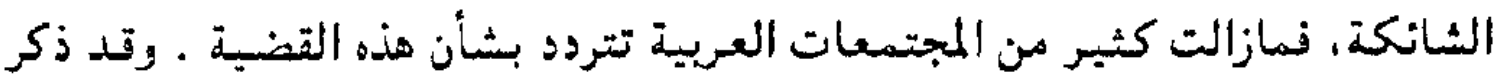

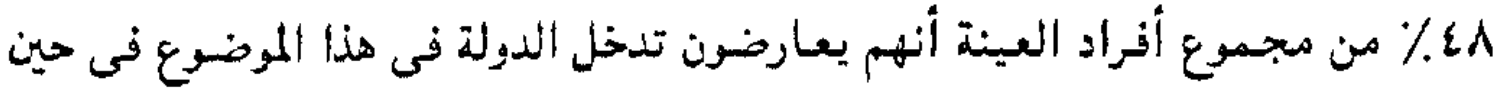

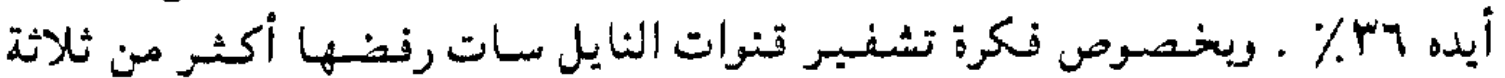

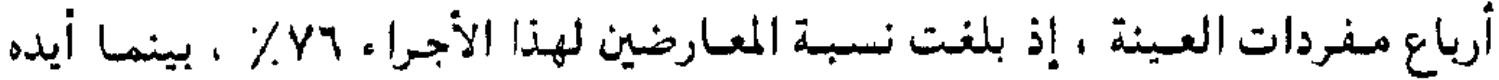

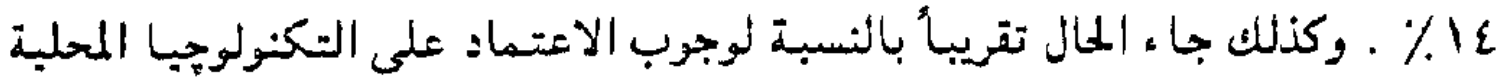

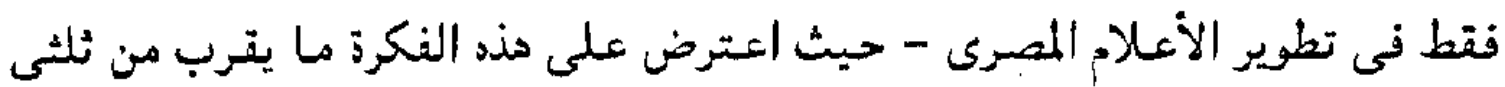

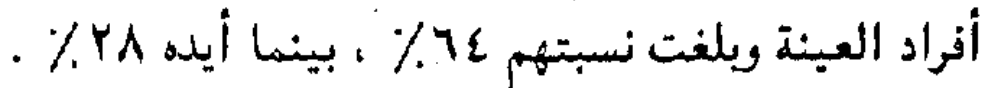

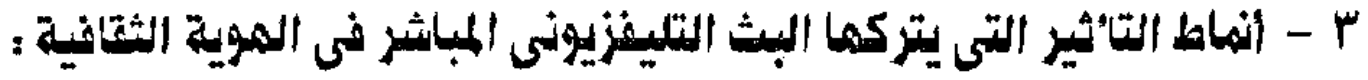

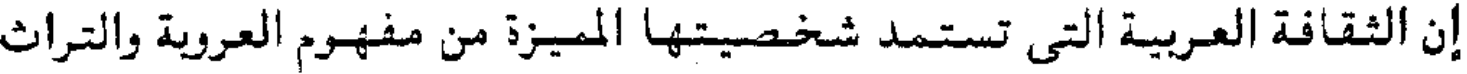

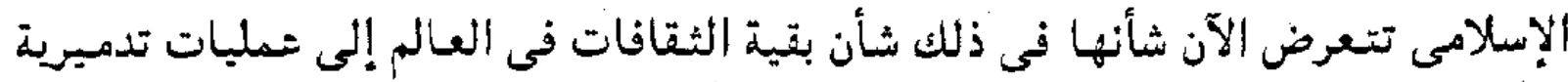

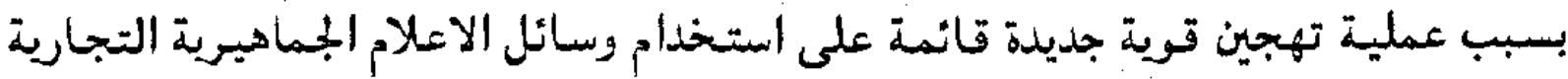

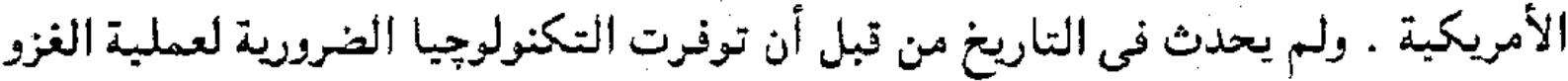

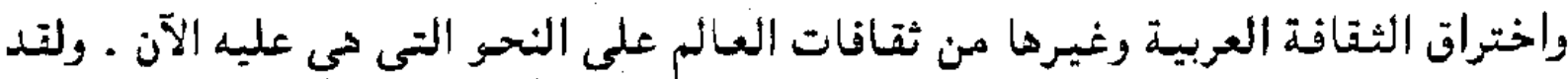

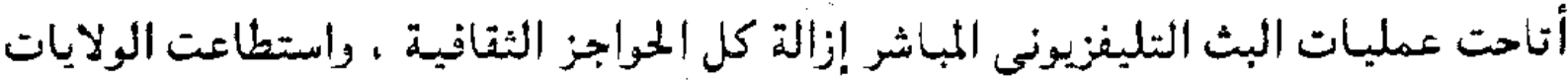

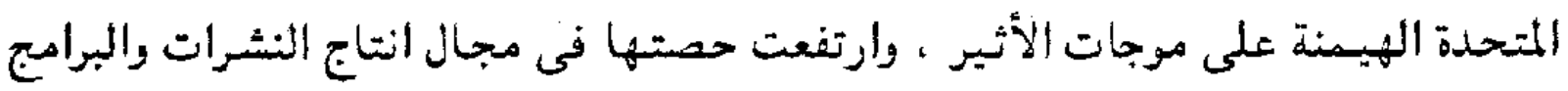

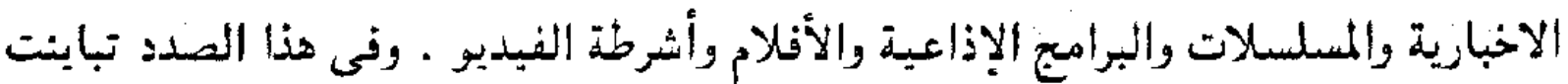

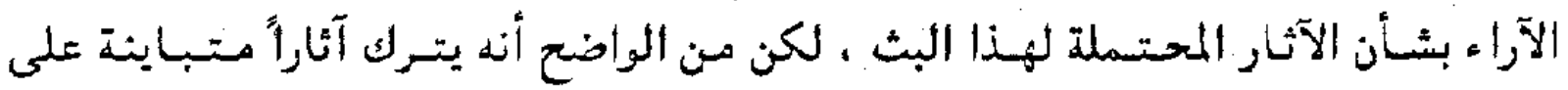

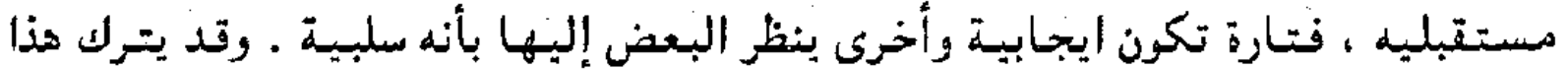

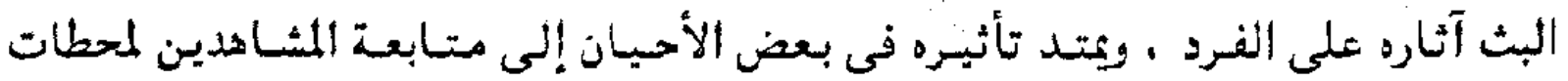

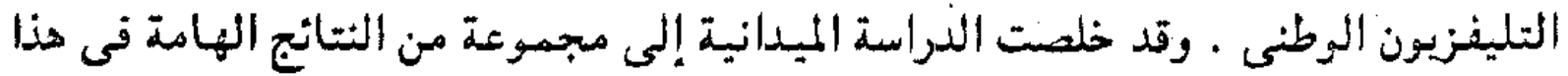

$$
\text { الموضوع وهى : }
$$

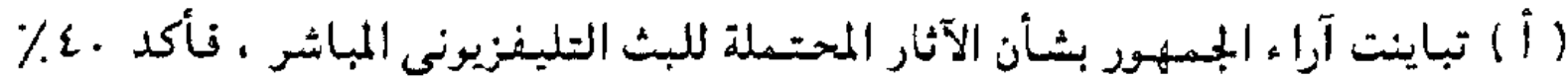

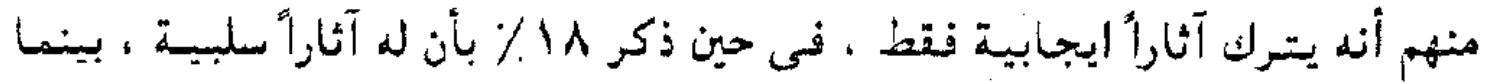

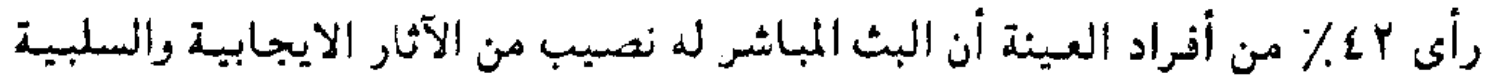

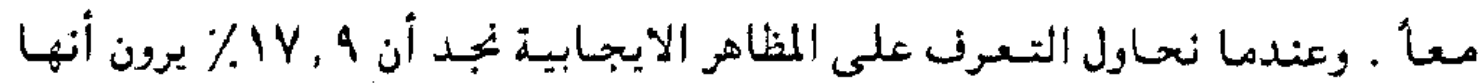

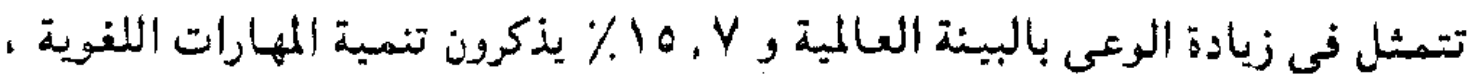

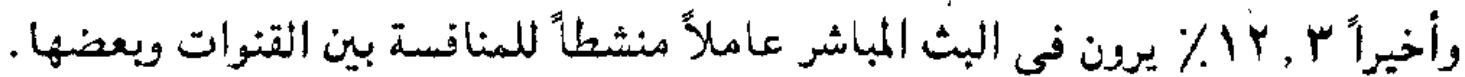




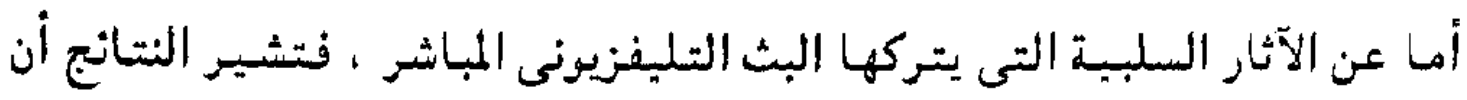

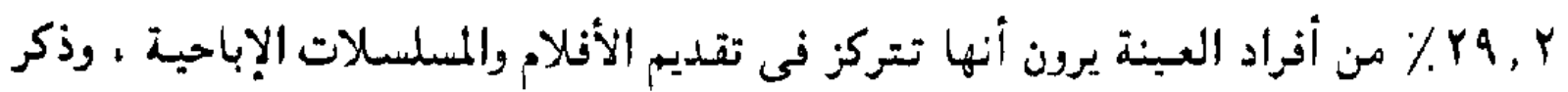

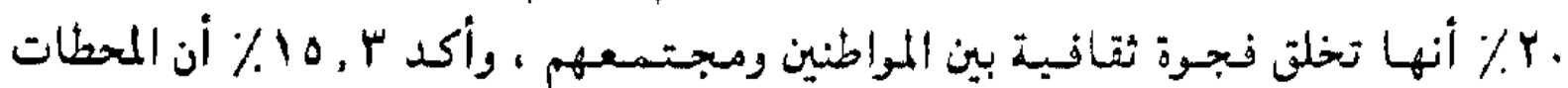

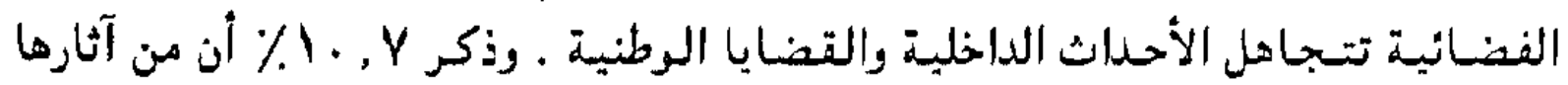

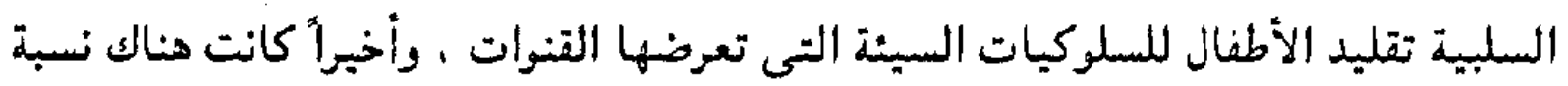

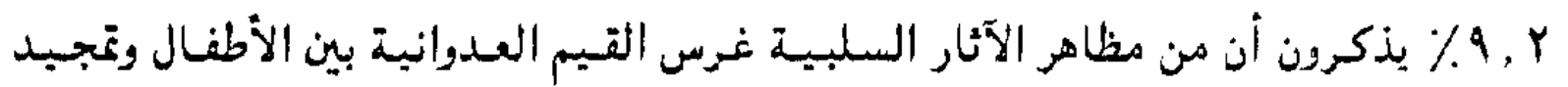

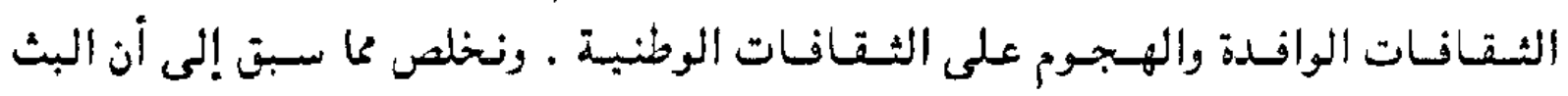

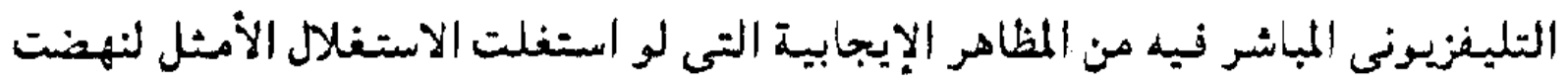

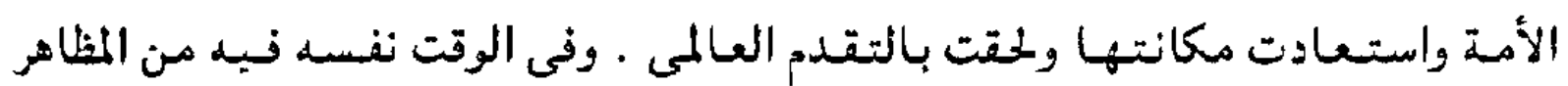

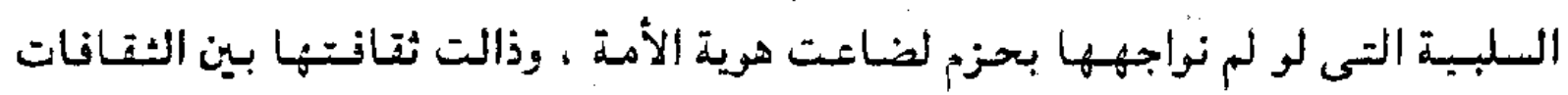

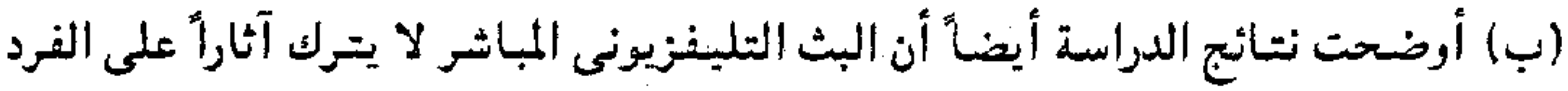

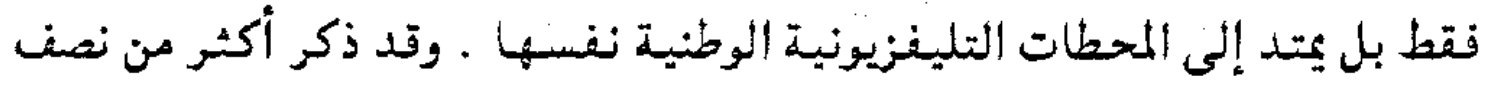

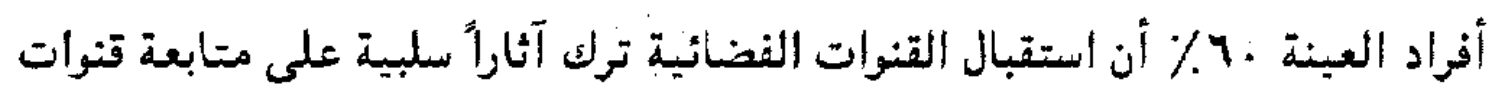

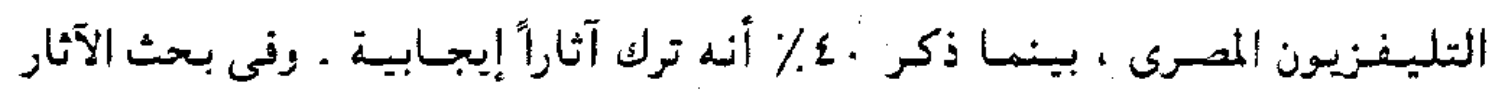

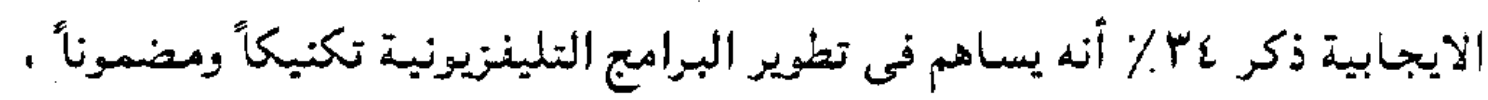

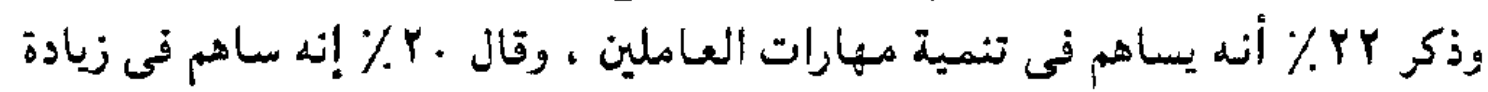

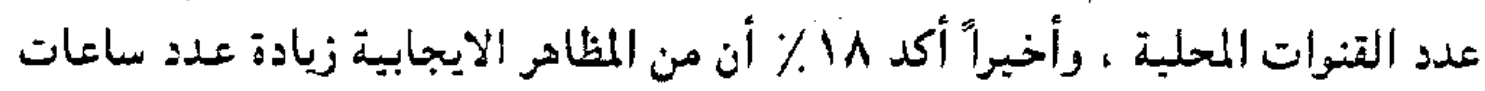

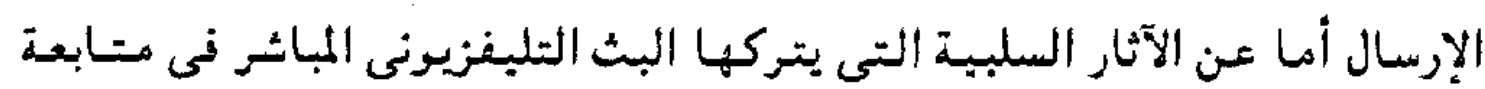

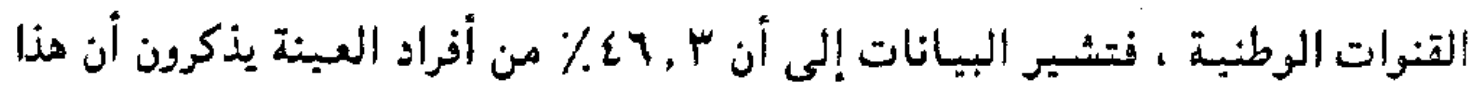

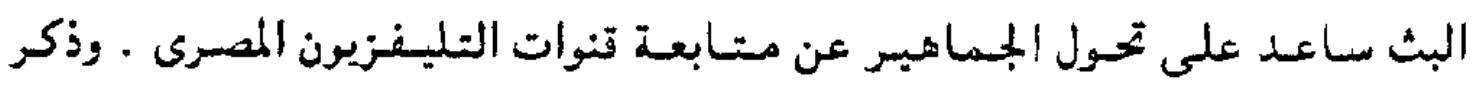

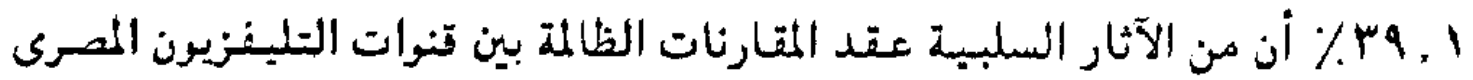

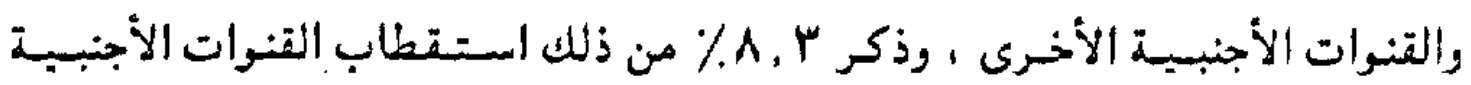

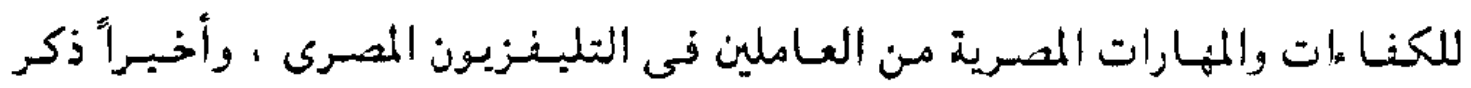

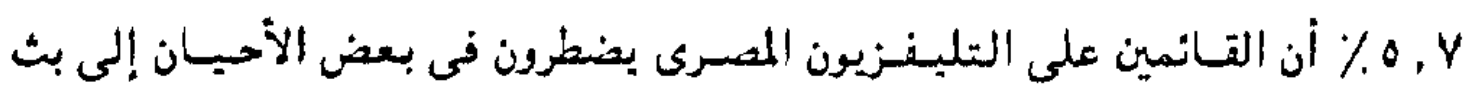

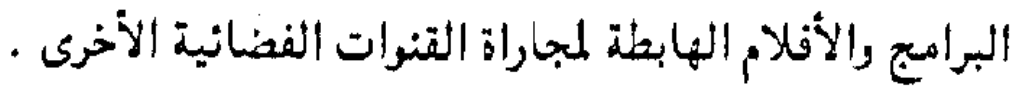

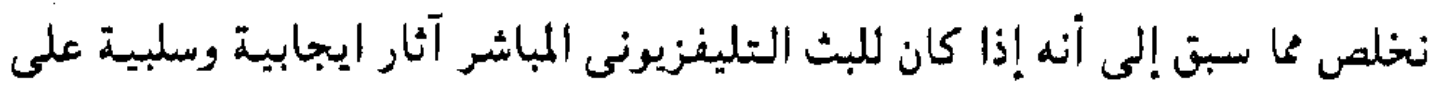

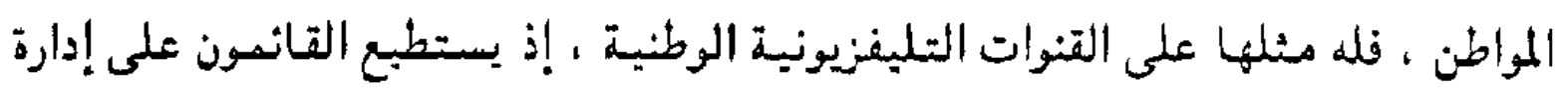


التليفزيون الصرى الاستفادة من المنافسة العالمية في مجال عرض البرادج والأخبار وتطويي

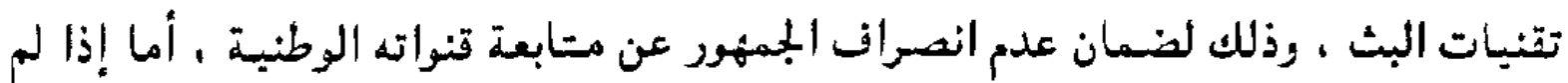

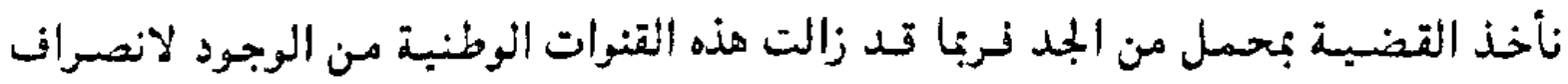

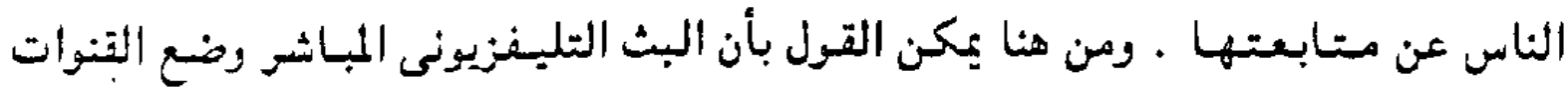

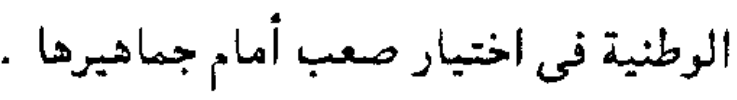

\section{ع - علاقة الظروئ الاجتماعية بالهوية الثقافية :}

وعلاوة على البث التليفزيونى المباشـر ودوره فى الهوية الثقانبة ، هناك العوامل

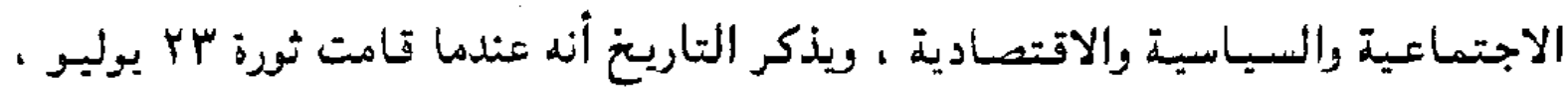

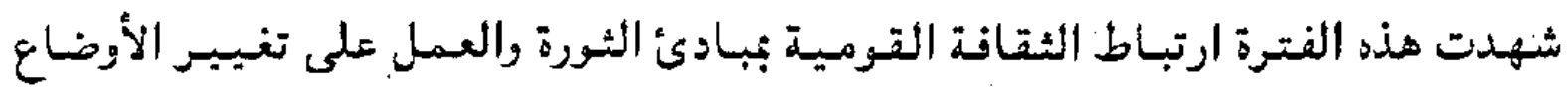

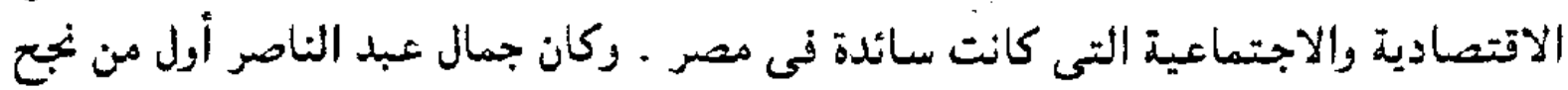

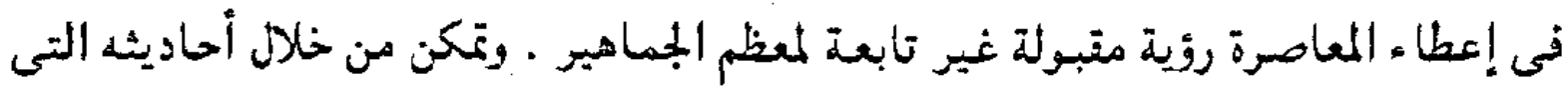

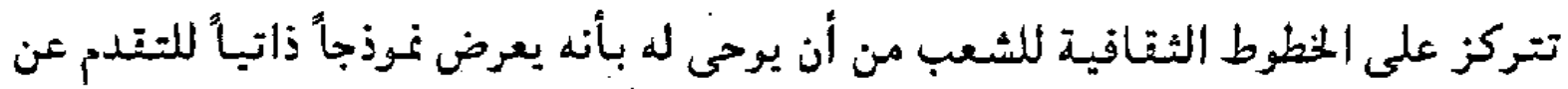

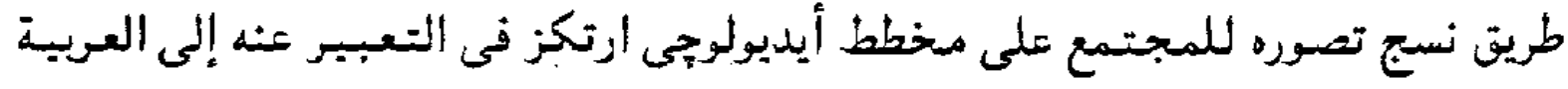

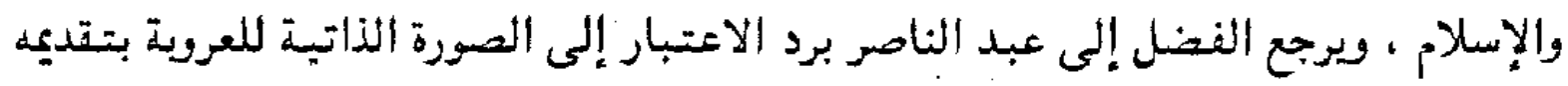

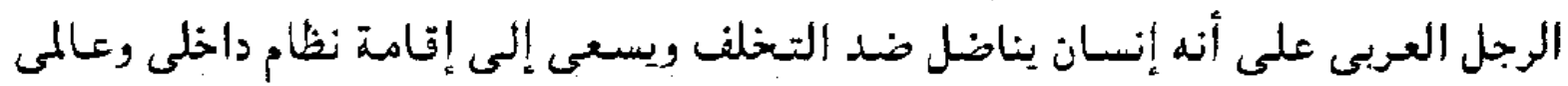

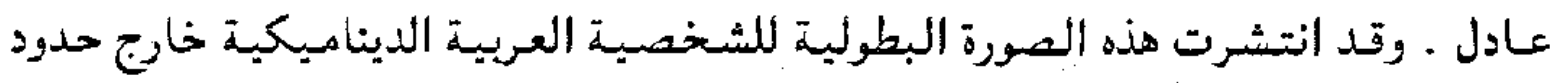
مصر

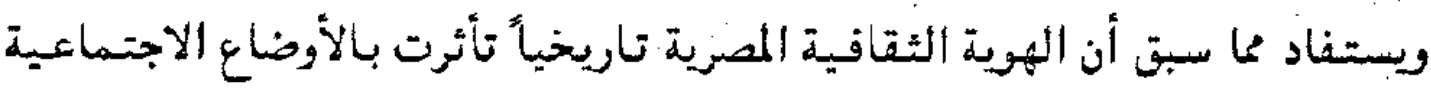

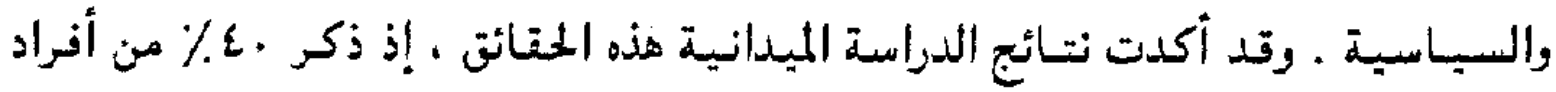

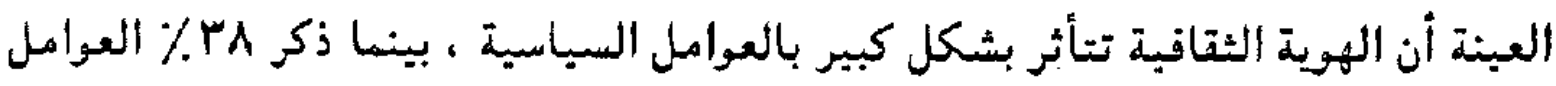

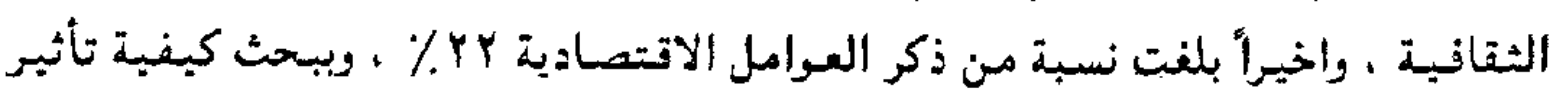

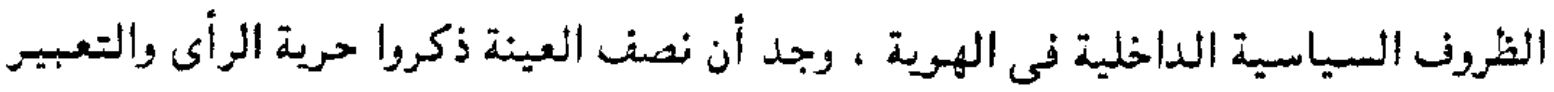

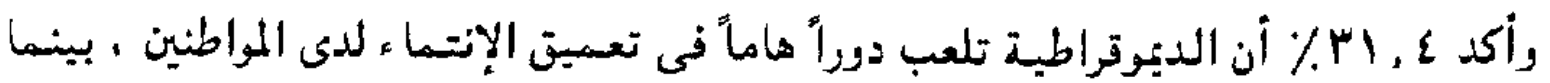

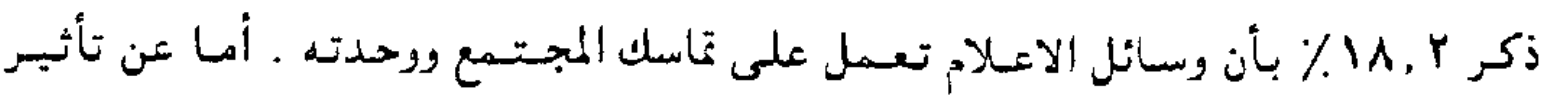

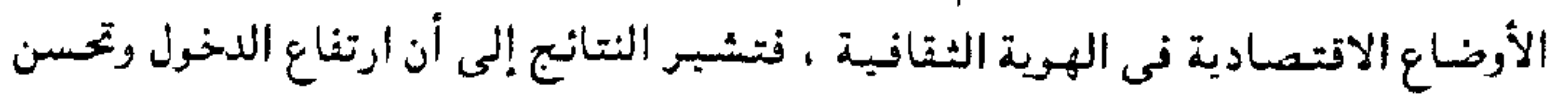

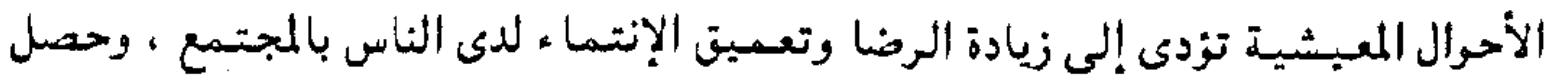

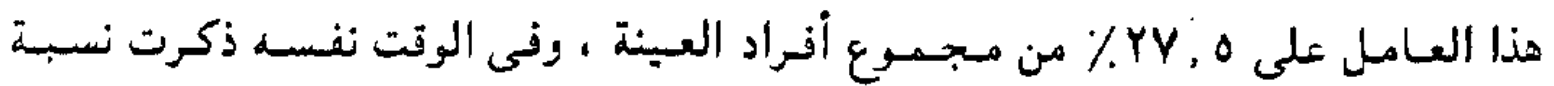

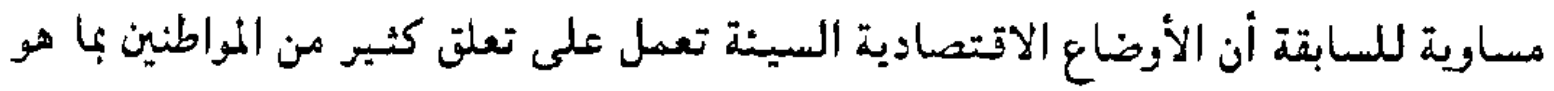




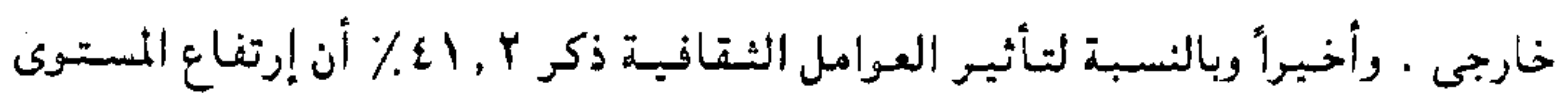

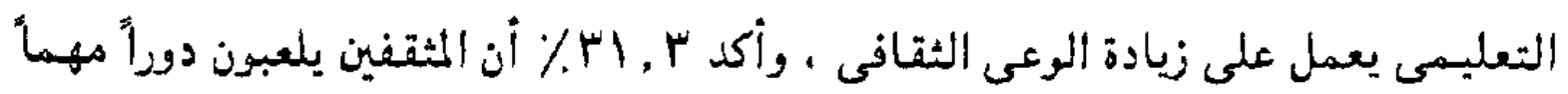

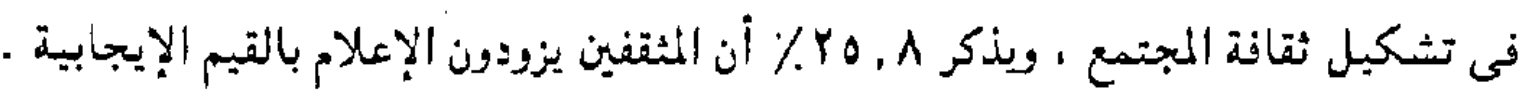
نخلص ما سبق أن الهية الثقافية تتأثر أبضان بالظروف السباسبة والاقتصادية

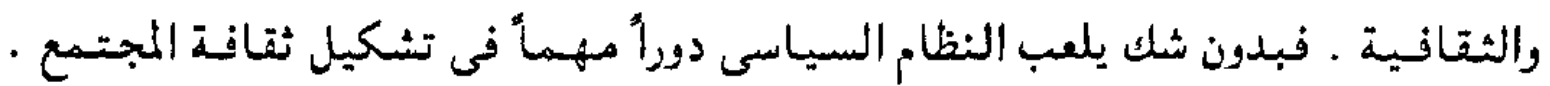

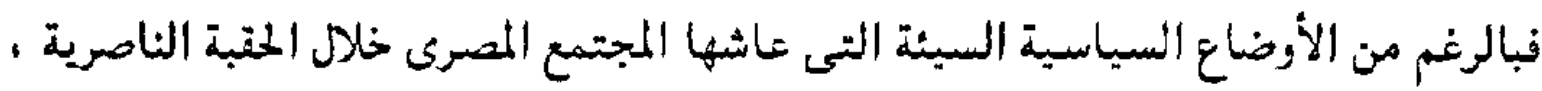

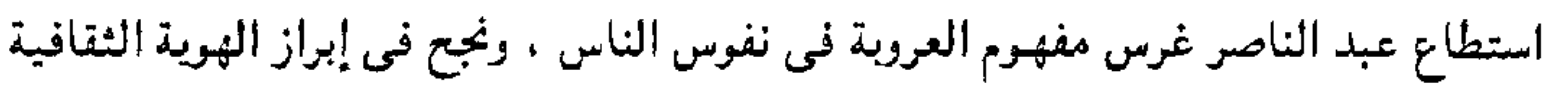

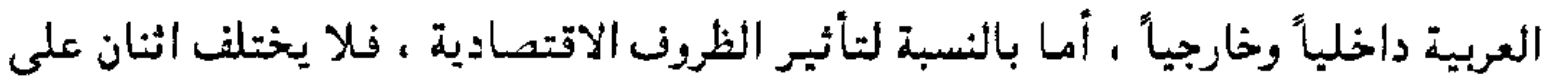

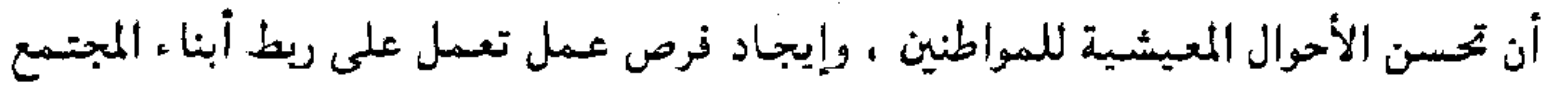

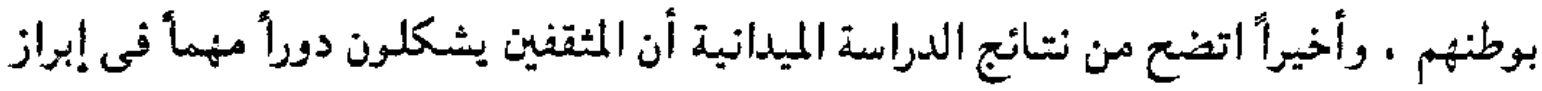
الهوية الثقافية وتوضيح معالمها بل غرسها فى نفوس المواطنين .

\section{ه - دور الدولة فى شماية الموية الثقانية :}

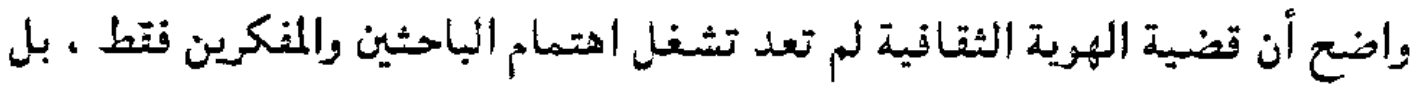

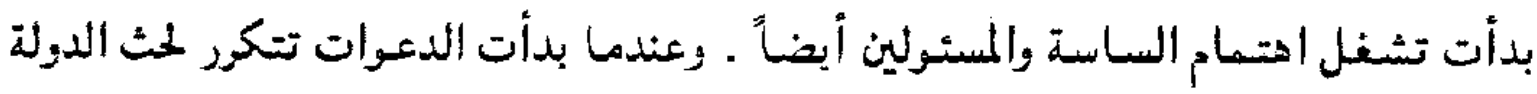

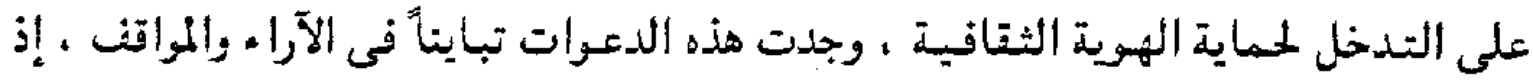

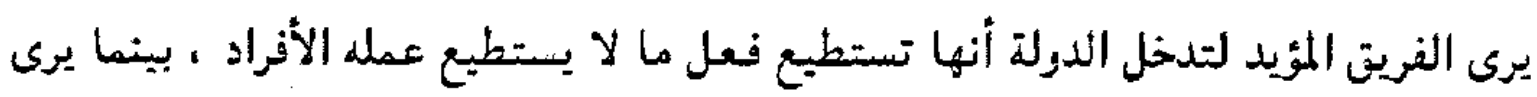

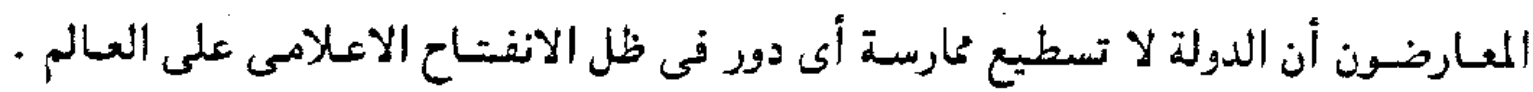

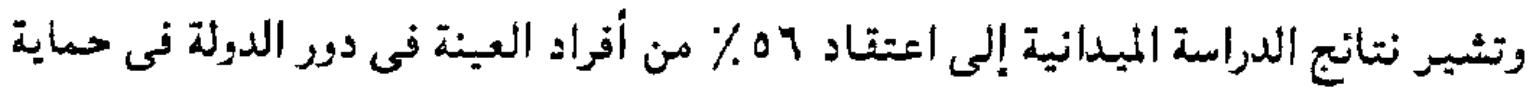

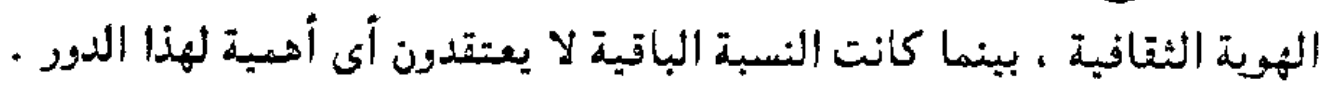

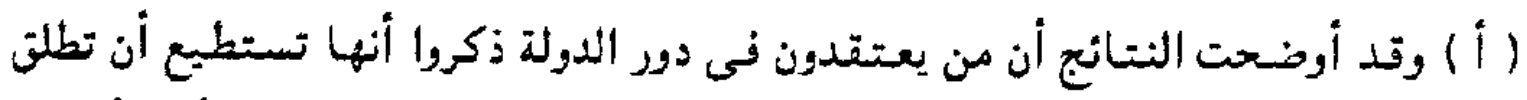

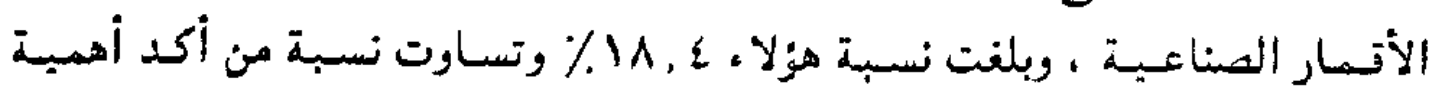

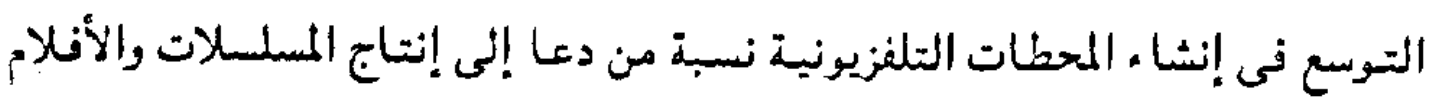

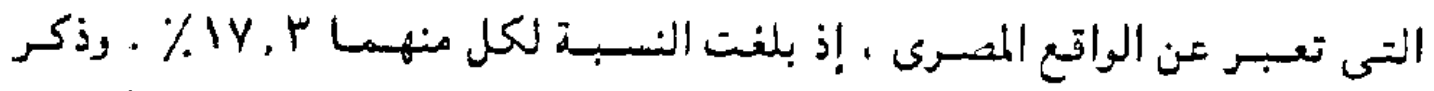

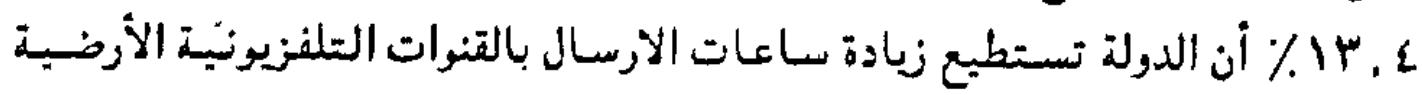

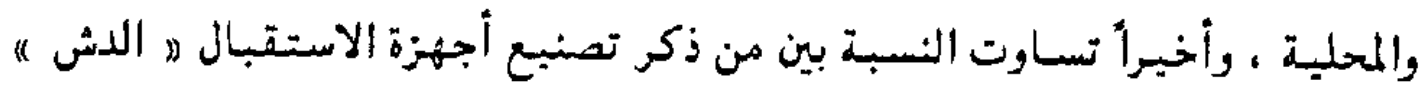

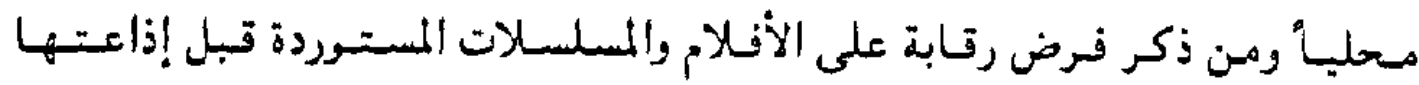

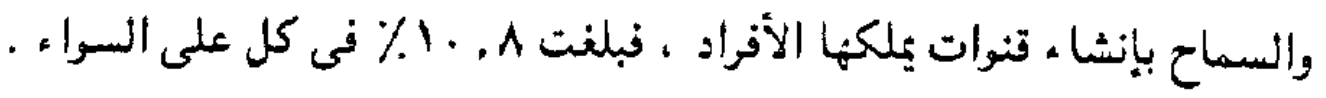




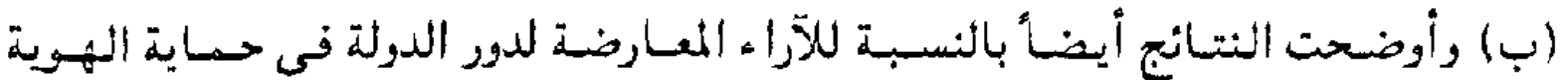

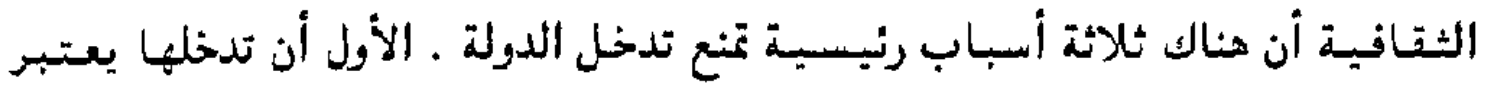

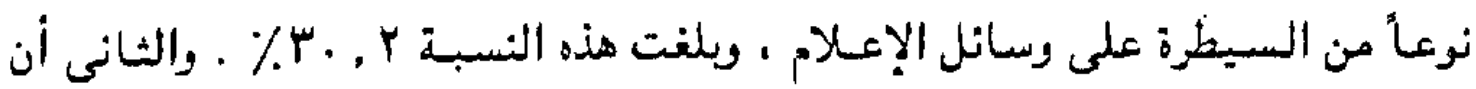

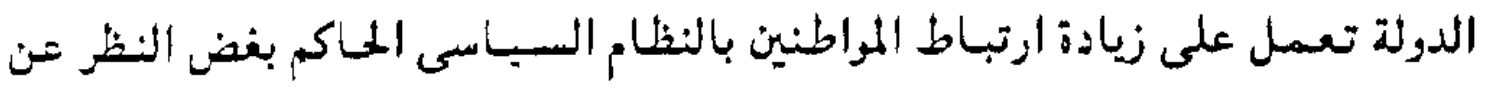

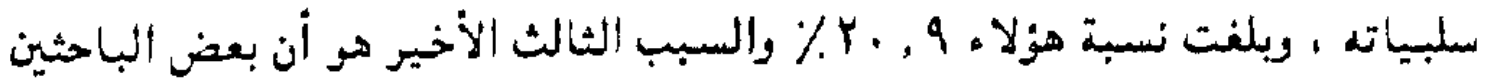

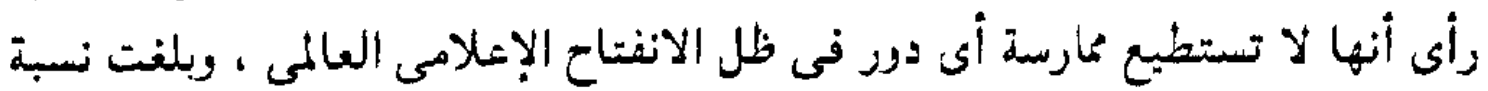

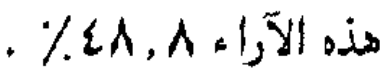

(ج) ) نخلص ما سبق أن هناك تيارين أساسيين بشأن دور الدولة فى حماية الهوية الثقافية.

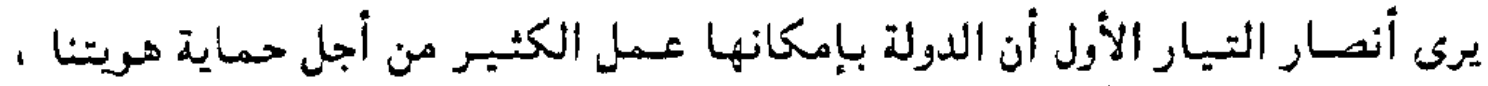

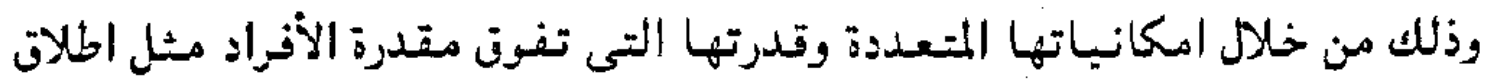

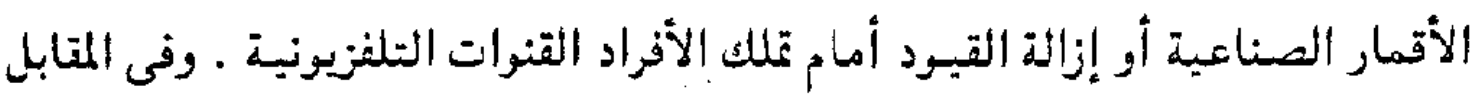

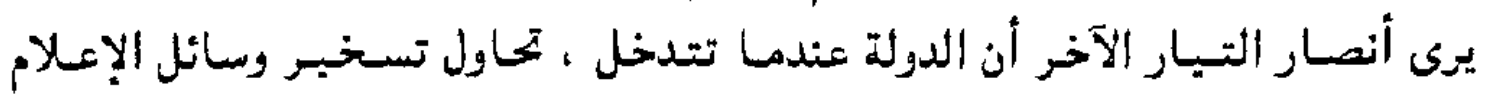

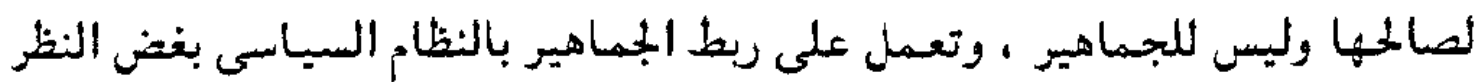

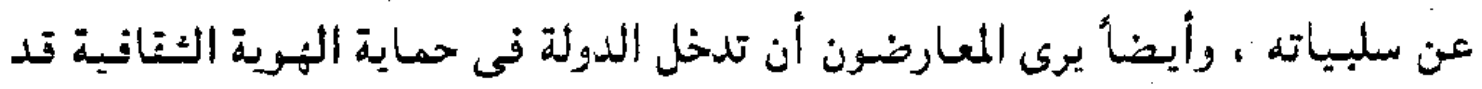

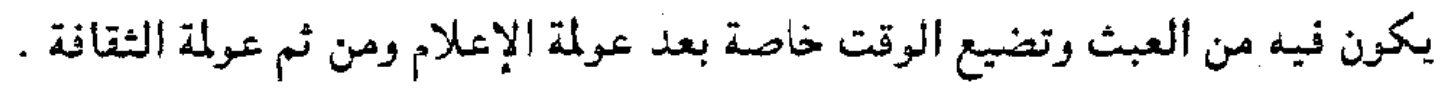

\section{خامسأ : الجهود المبذولة للحفاظ على الهوية الثقافية العربية :}

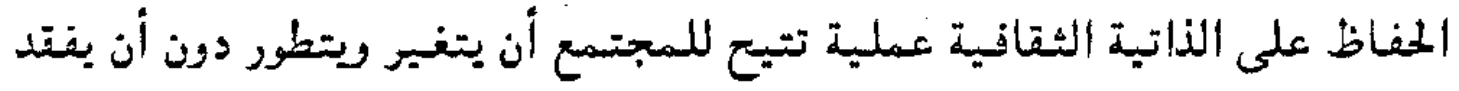

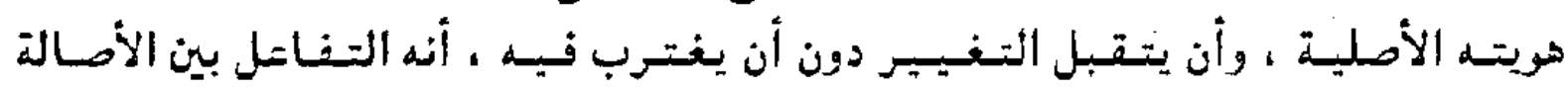

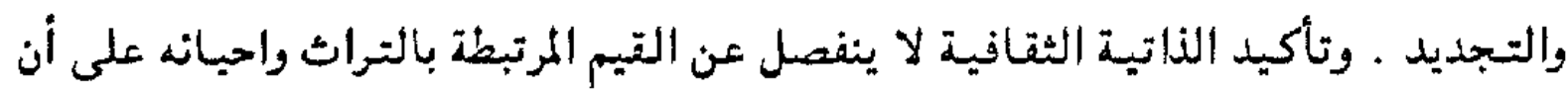

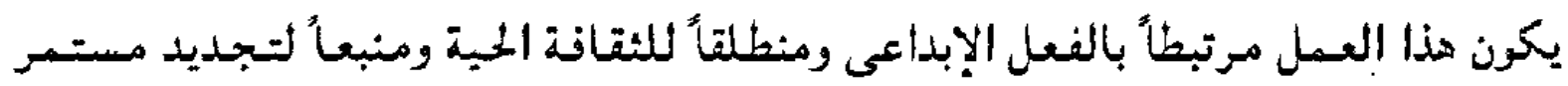

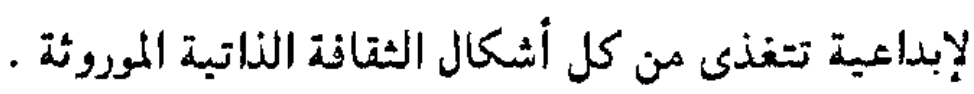

ولتد حارلت بعض الدول اقامة استراتبجيات إعلامبة تؤكد هويتها الثقافبة .

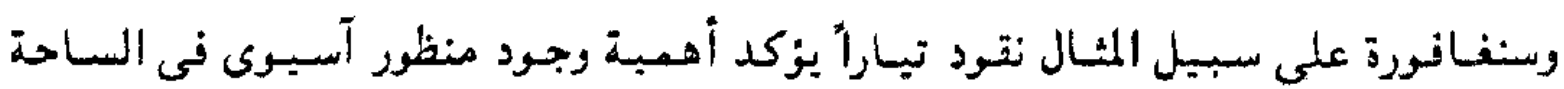

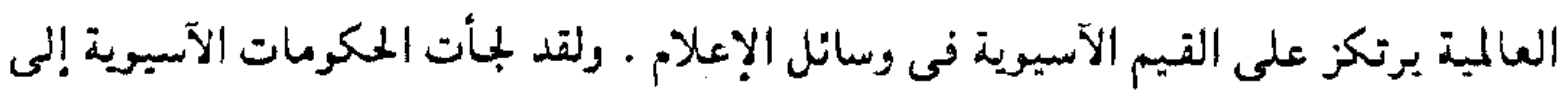

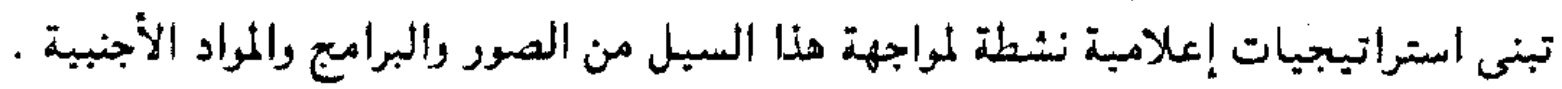

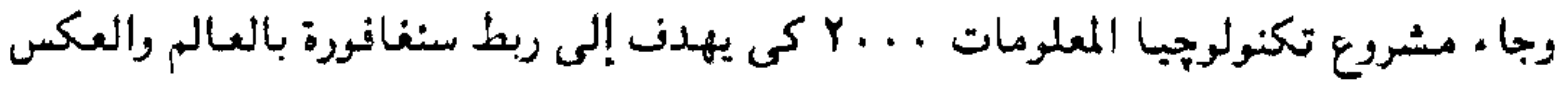

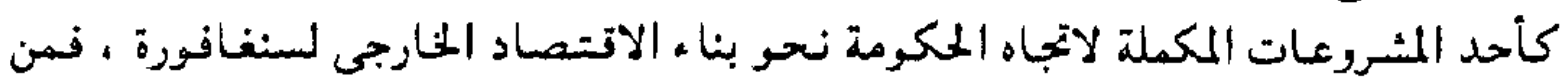

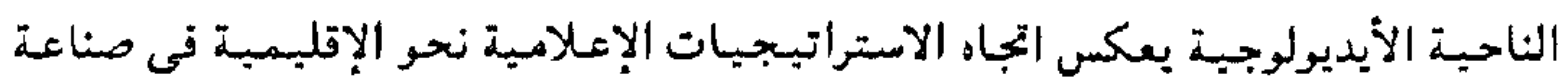


الصحافة والإزاعة ، الرغبة الواعية لتغبير فبرة الشرق المحتل ـ وتمثلت الاستراتبجيات

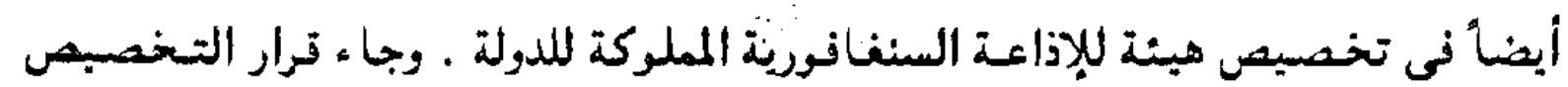

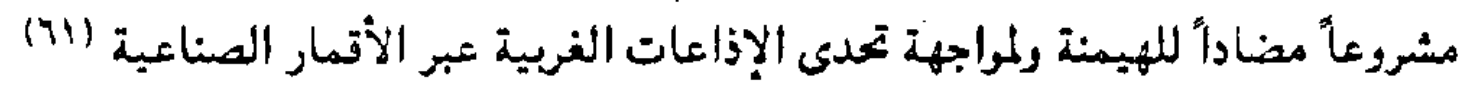

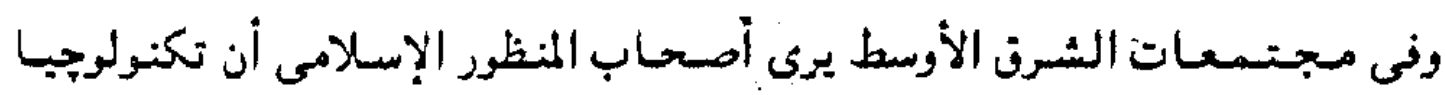

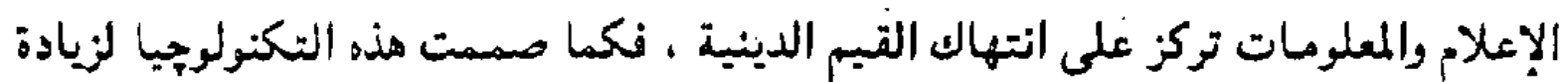

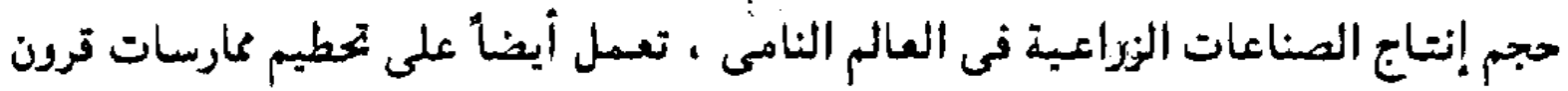

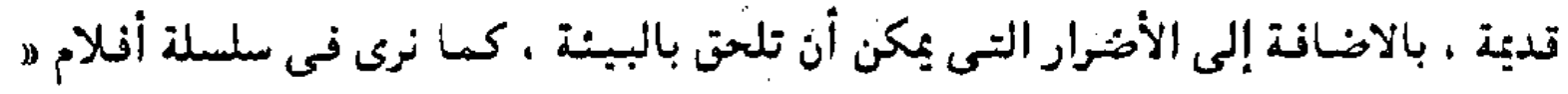

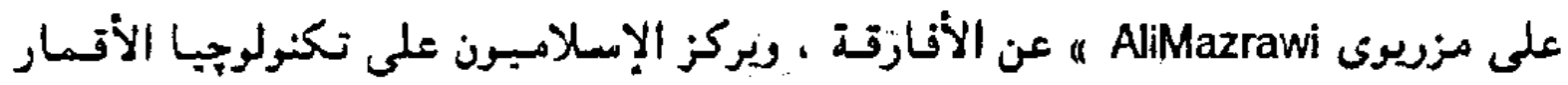

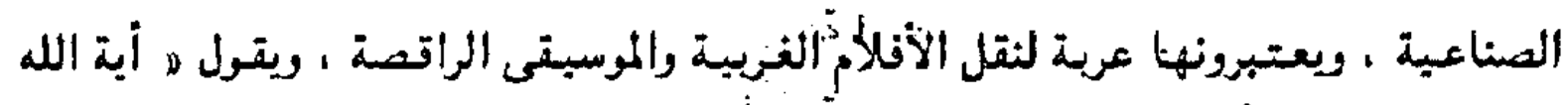

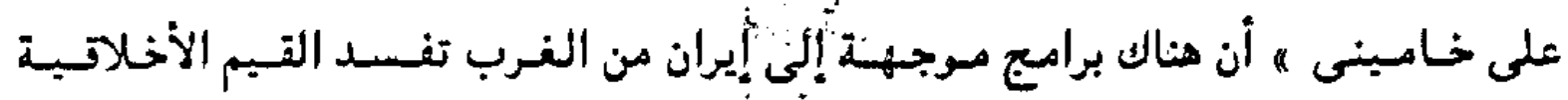

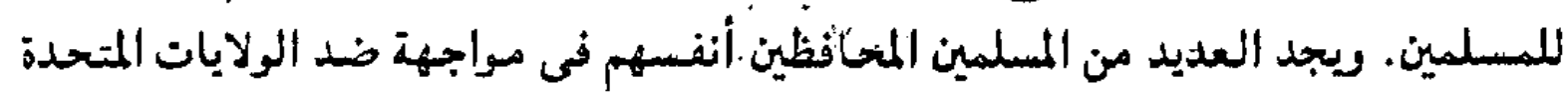

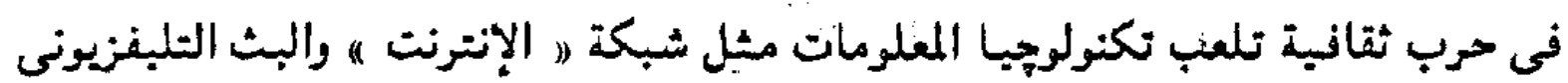

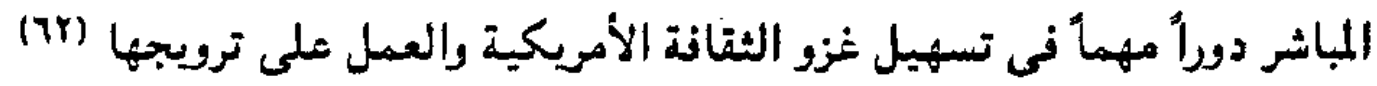

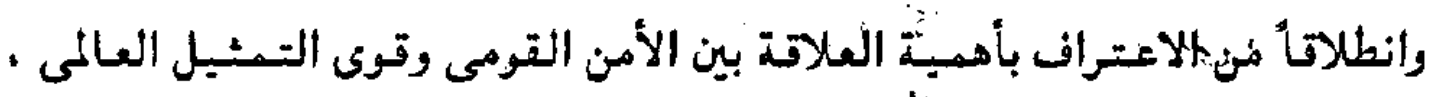

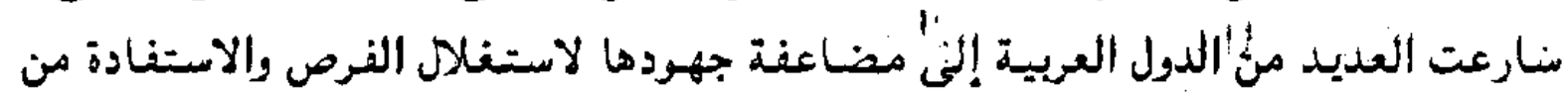

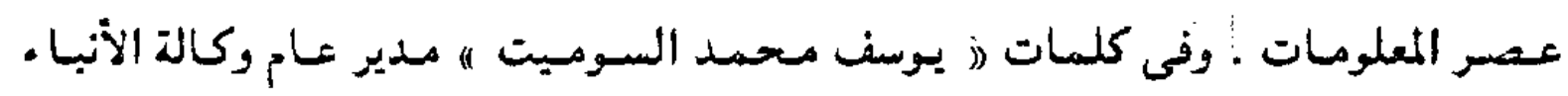

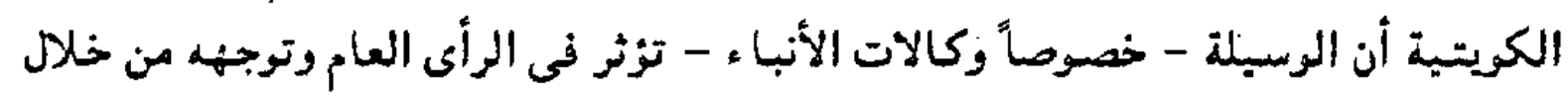

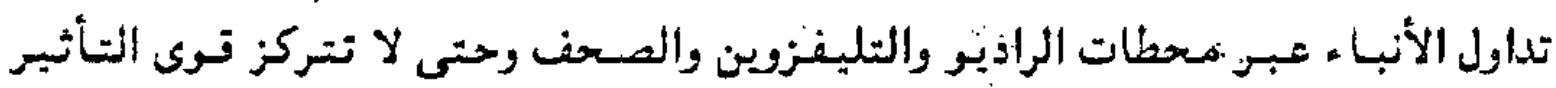

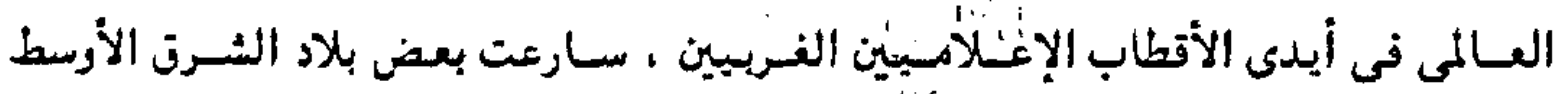

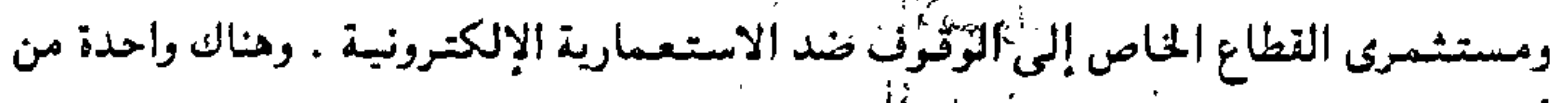

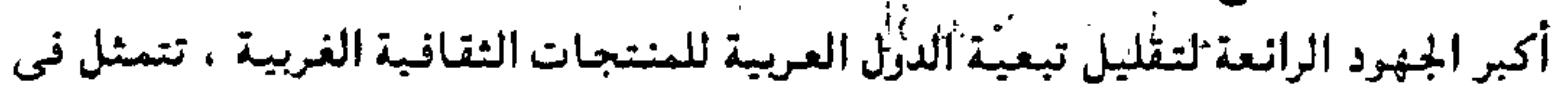

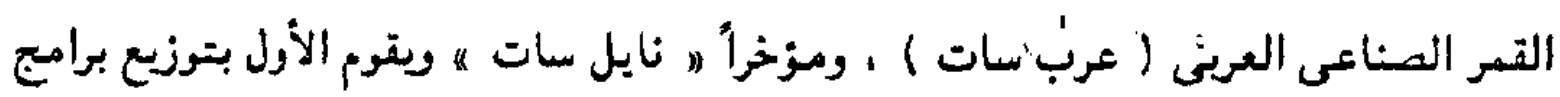

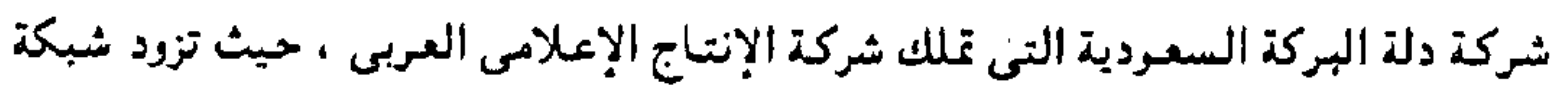

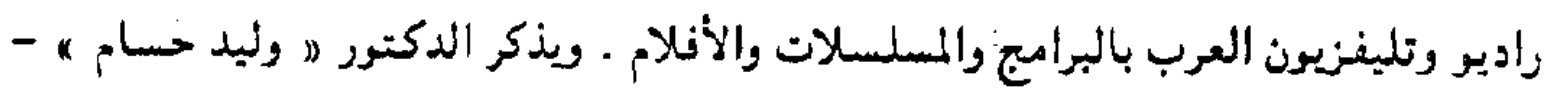

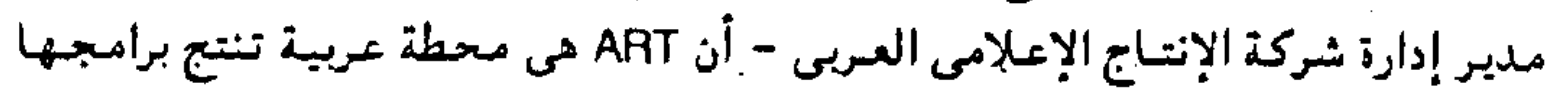

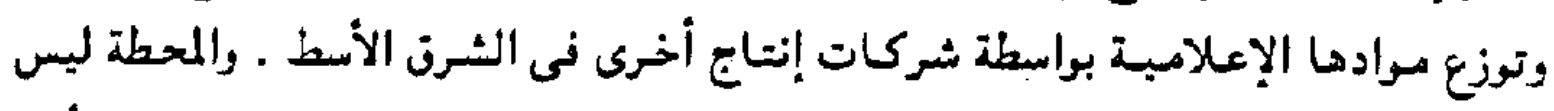

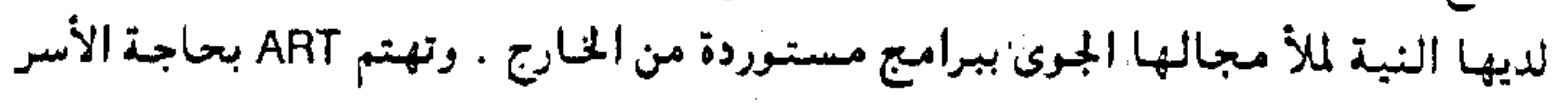

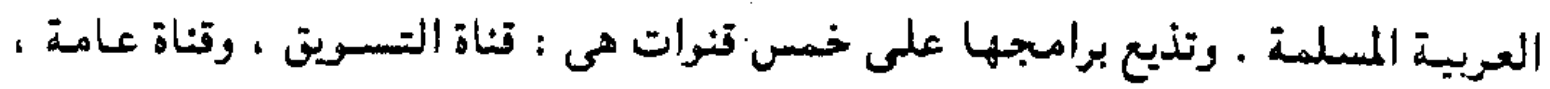


وراحدة للرياضـة ، وواحدة للأفلام ، وقناة للأطفال ، وراحدة للمسوسيقى ، وتهدف قنوات

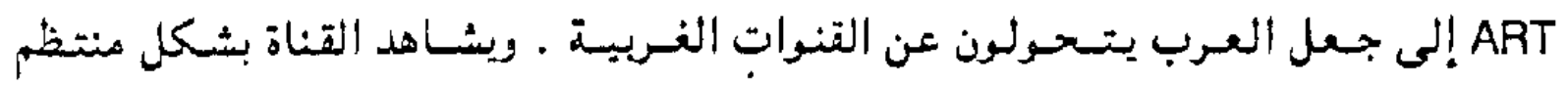

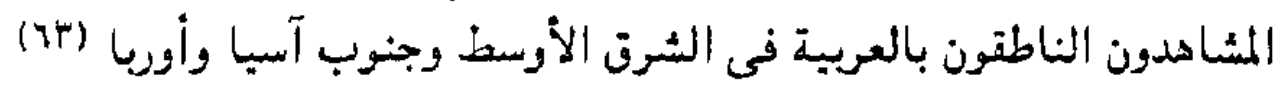

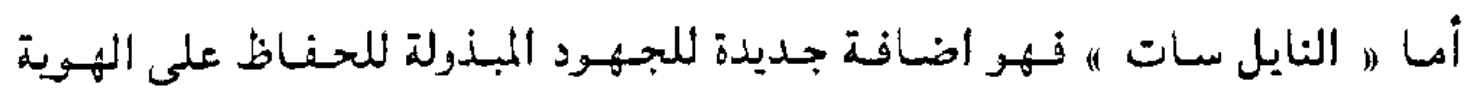

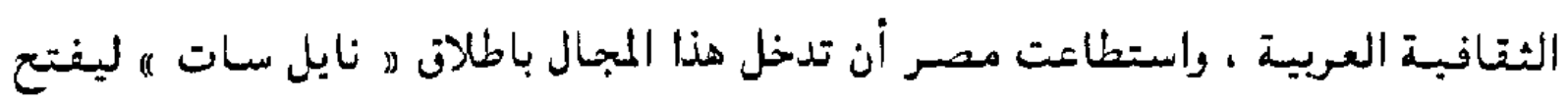

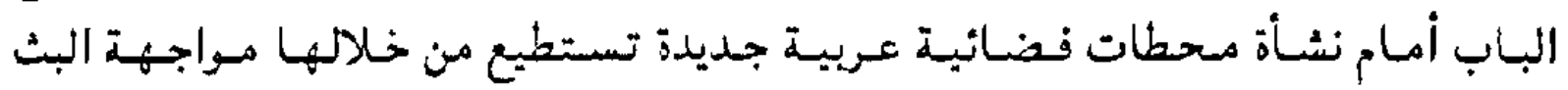

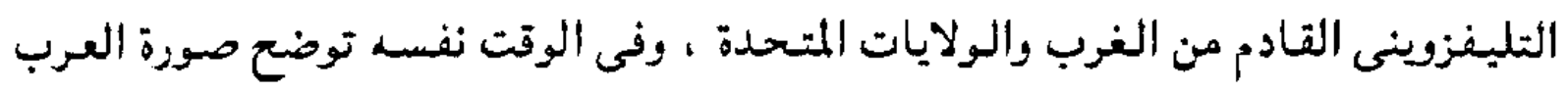

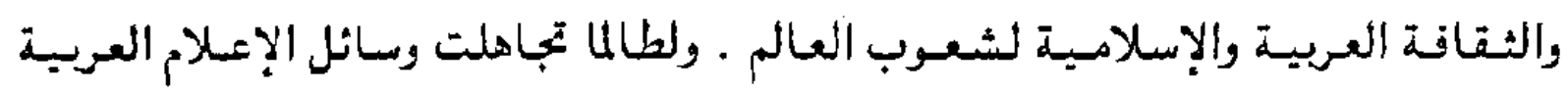

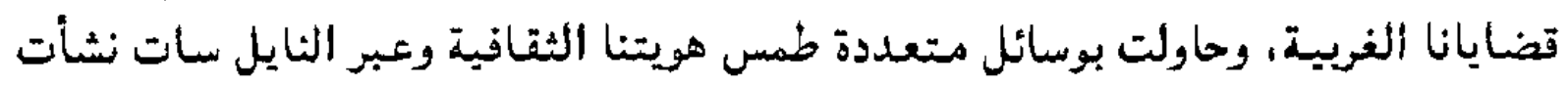

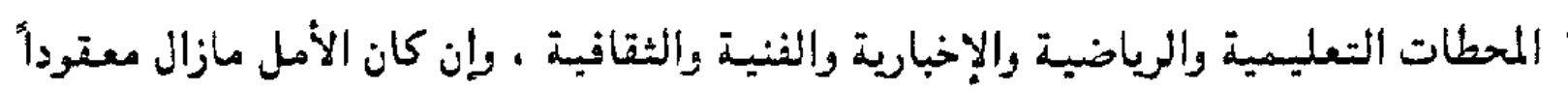

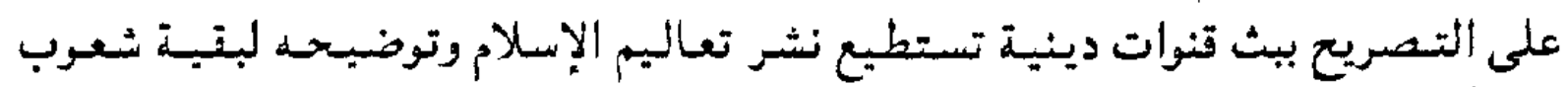

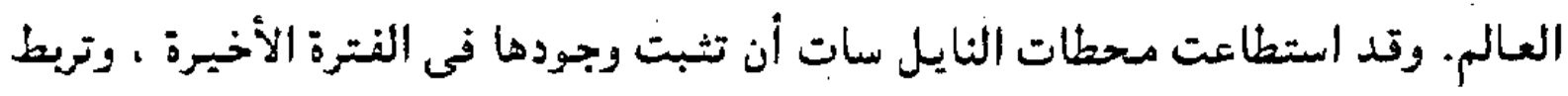

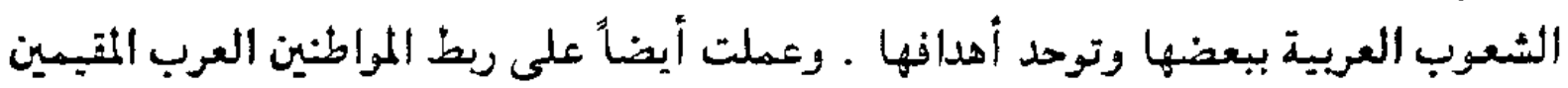
فى الخارج بأوطانهم الأصلية .

ومن وسائل حماية الهيوية الثقافية ما تقوم به بعض اللدول من تحديد نسـبة البرامج

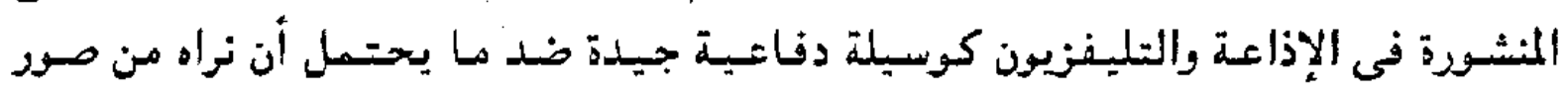

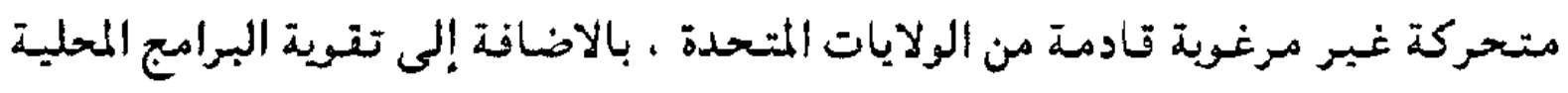

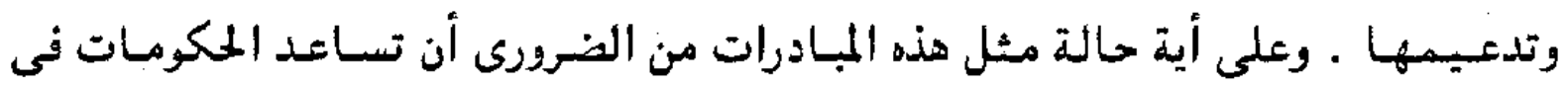

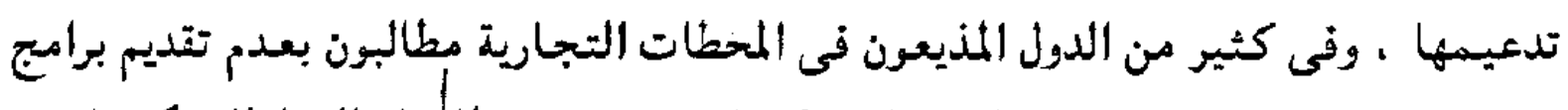

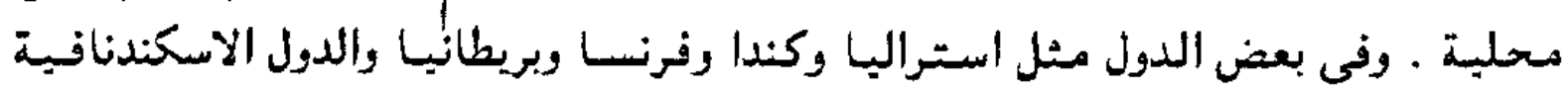

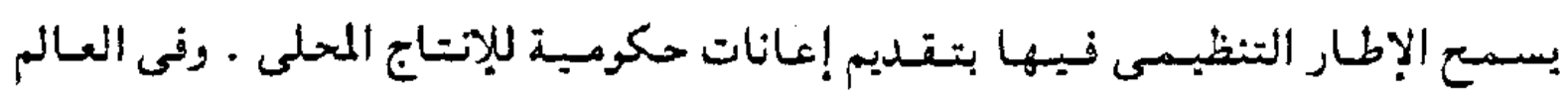

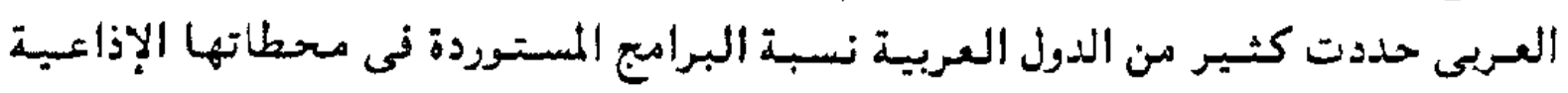

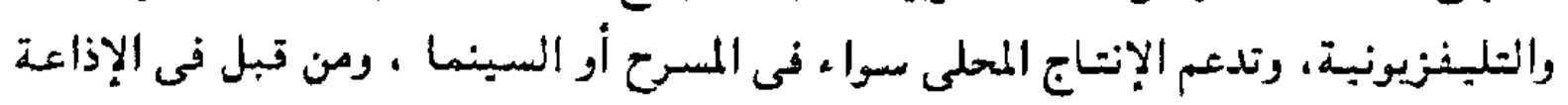

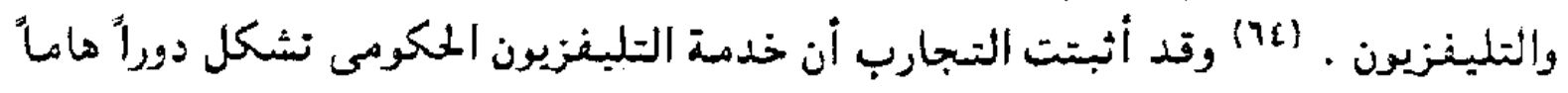
فى تزويد الجماهير بخدمات متنوعة مثل برامج التسلية والبرامج التعليمية والبرامج غيرير

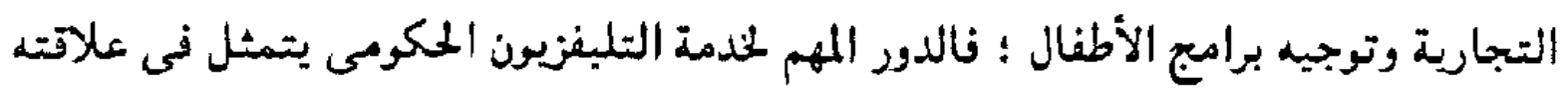

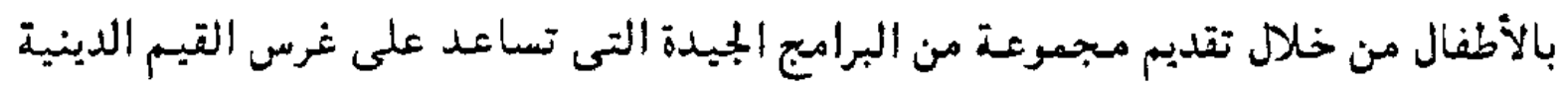
في نفوس الأطفال . 
وهناك نوذج من جهود الدول العريبة لاستخدام تكنولوجيا المعلومات فى المقاومسة

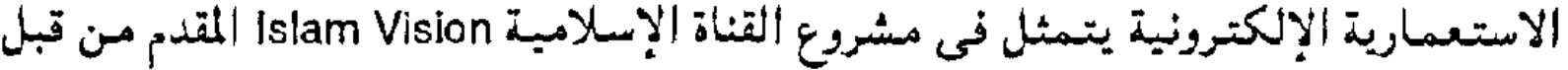

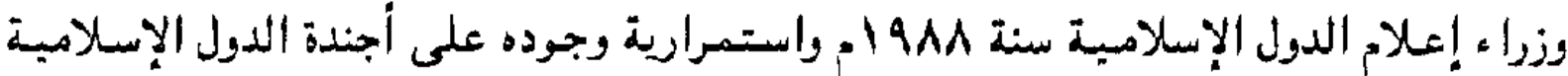

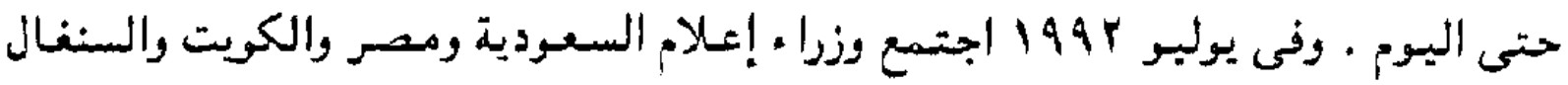

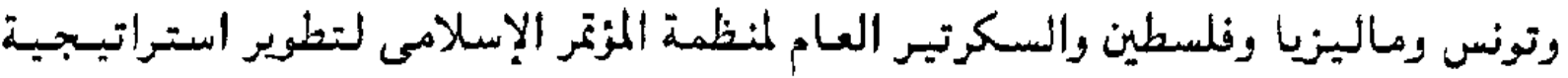

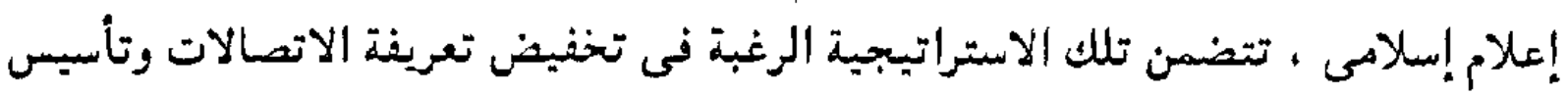

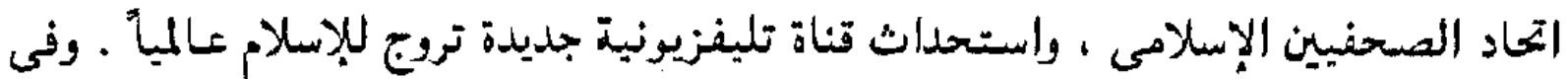

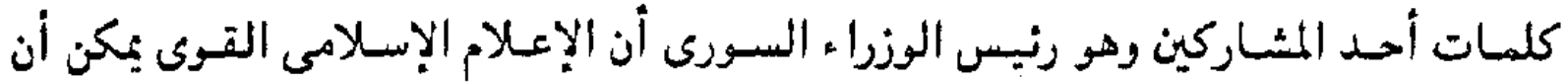

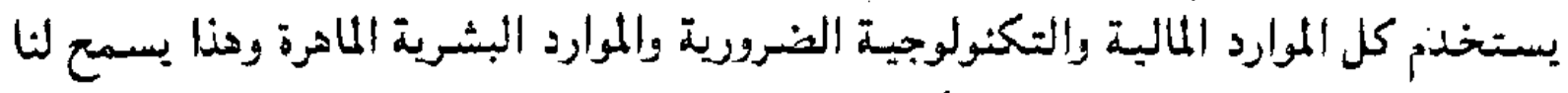

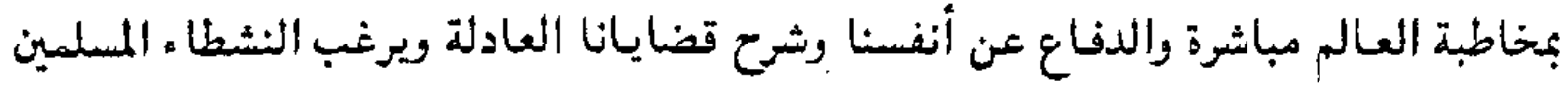

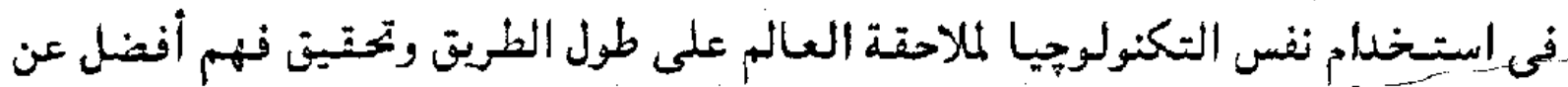

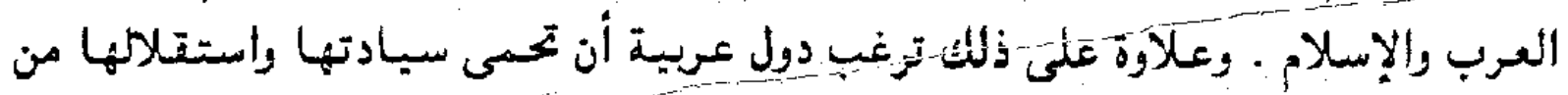

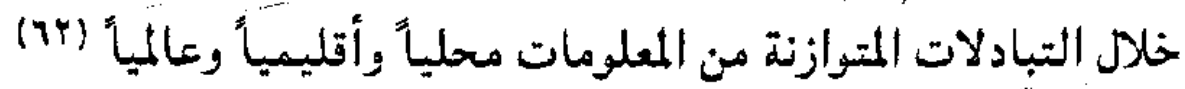

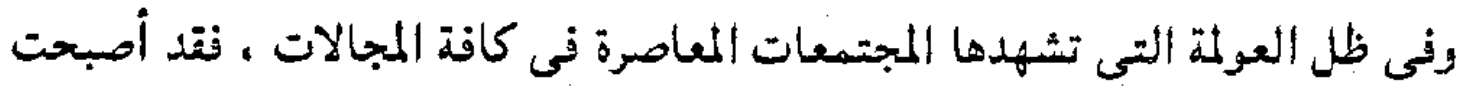

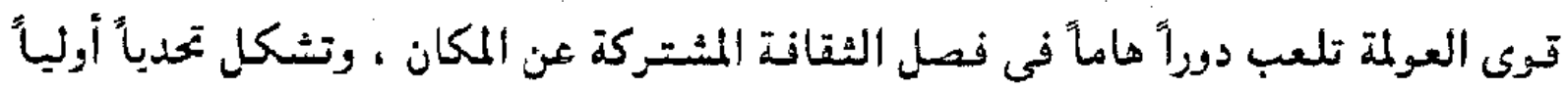

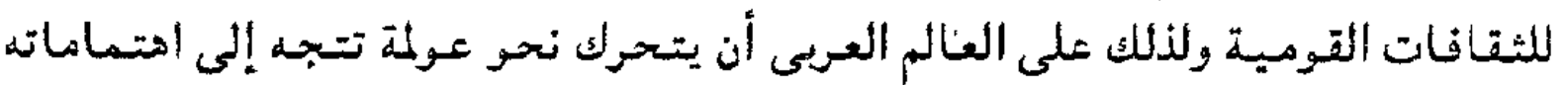

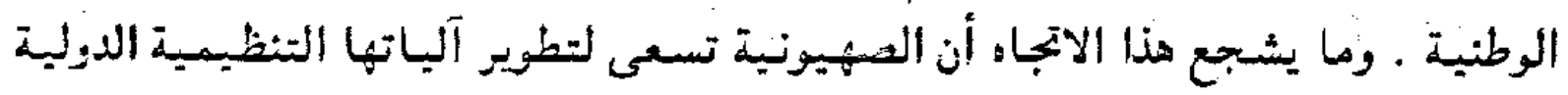

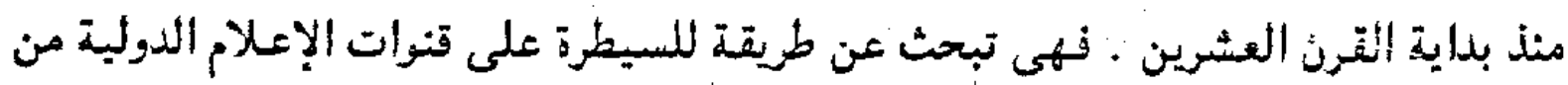

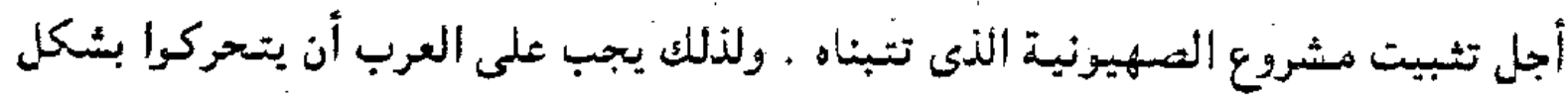

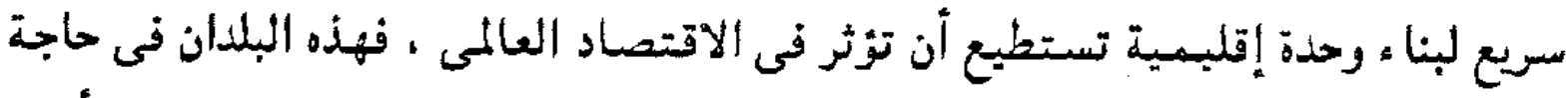

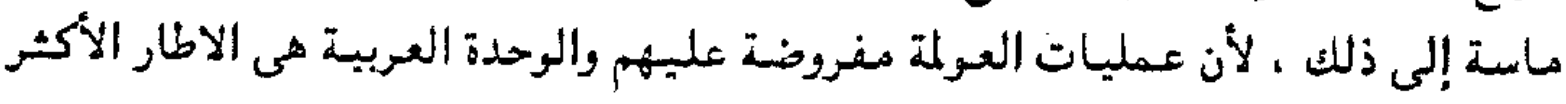

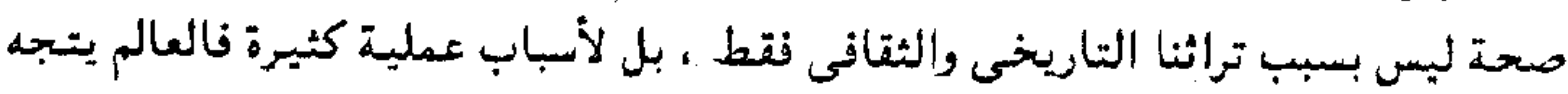

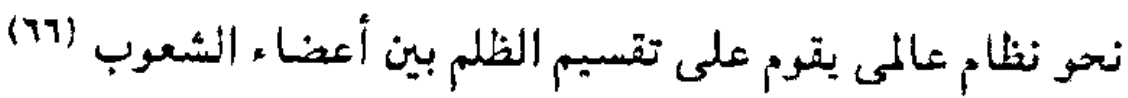

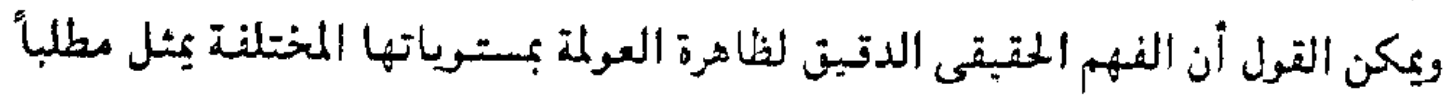

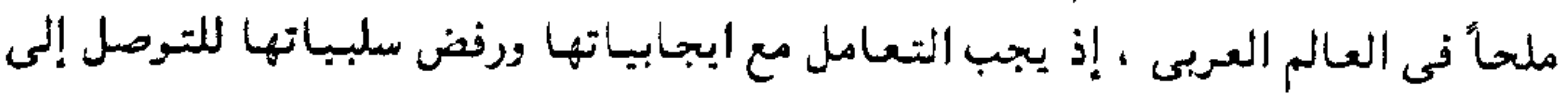

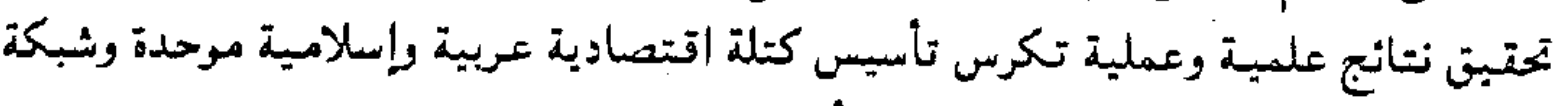

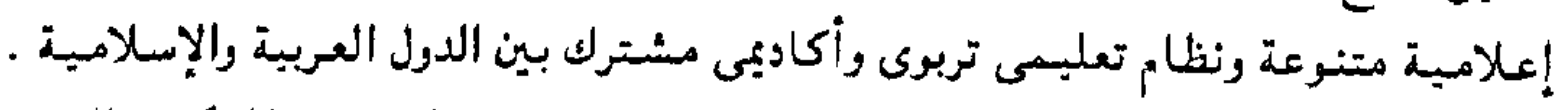

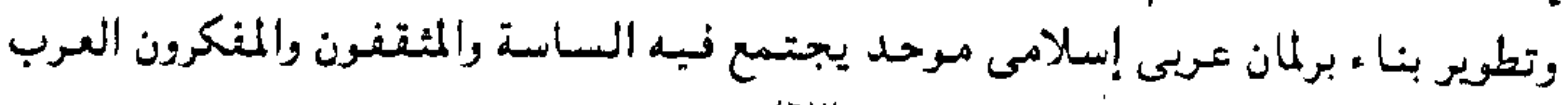

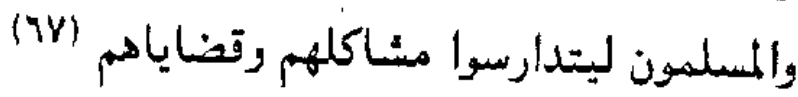




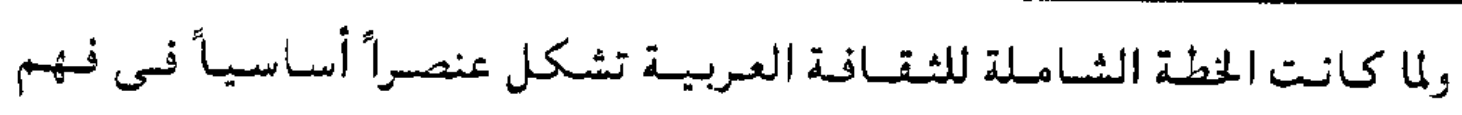

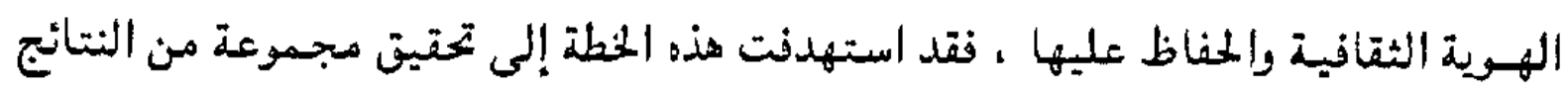

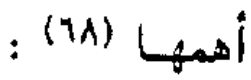

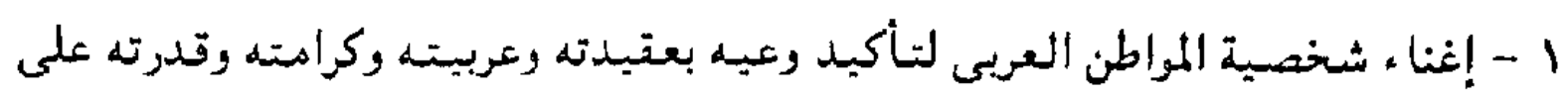

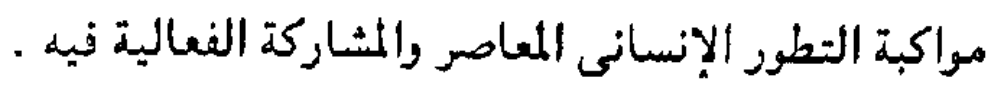

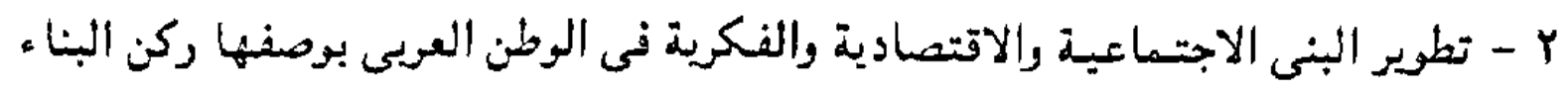

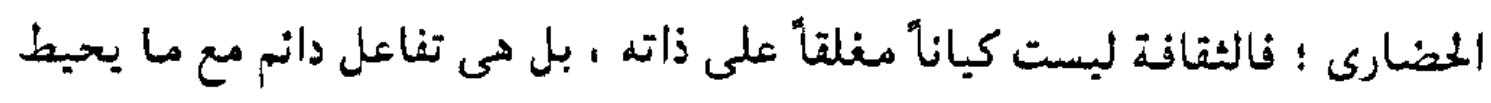

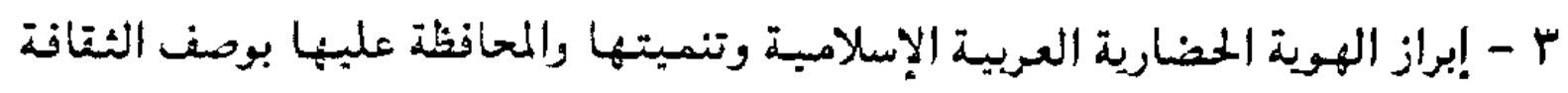

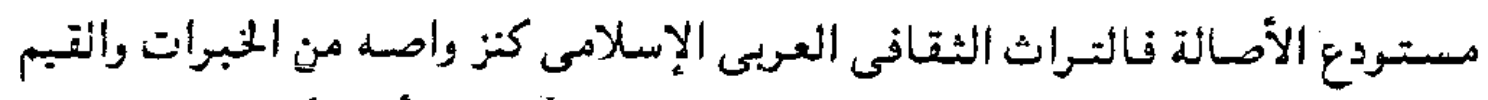

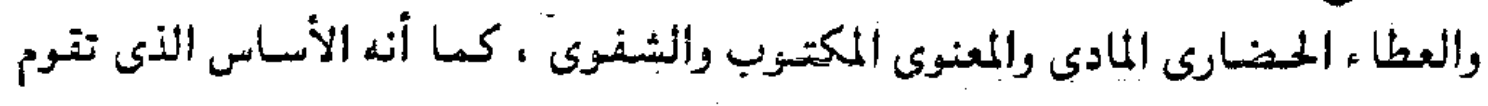
عليه الهوية الثقافية للأمة .

ع - تأكيد الوحدة بين أقاليم الوطن العربي وزيادة أواصرها ؛ فالثقافة العريبة هى النسيجة

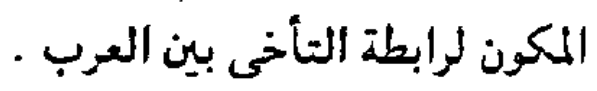

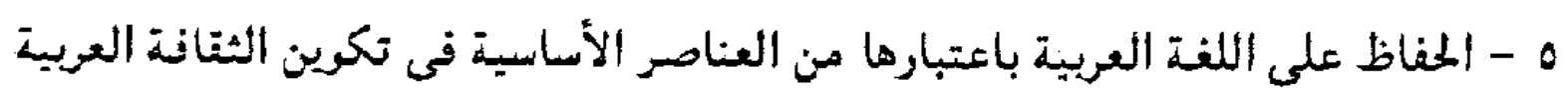

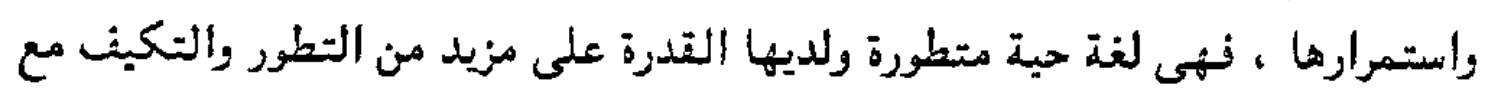

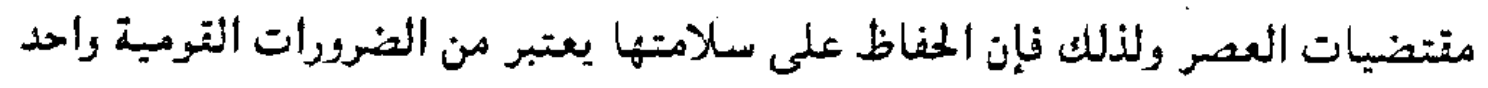
مستلزمات صيانة الذاتية الثقافية .

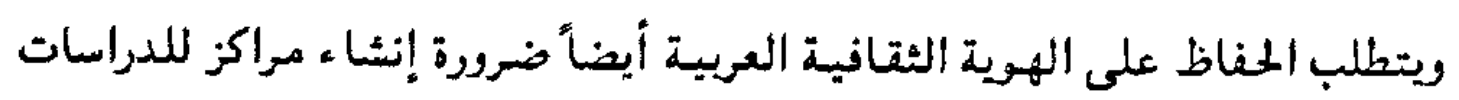

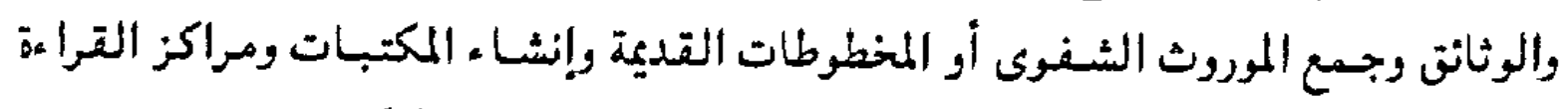

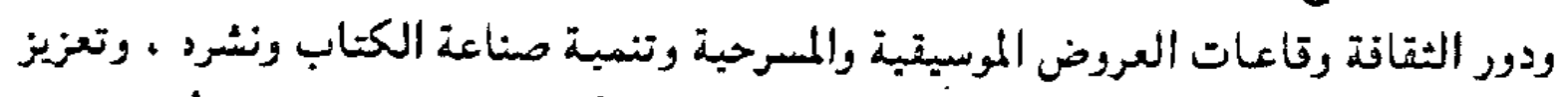

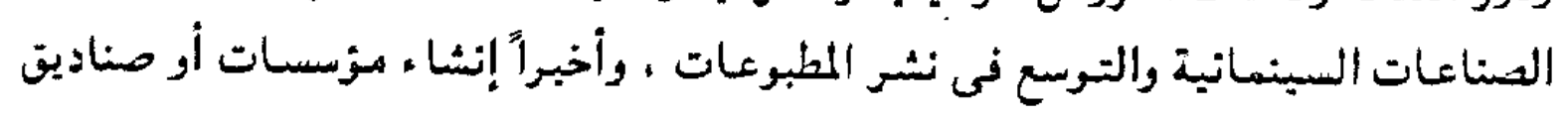

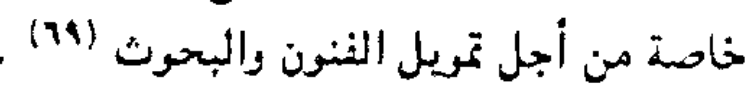

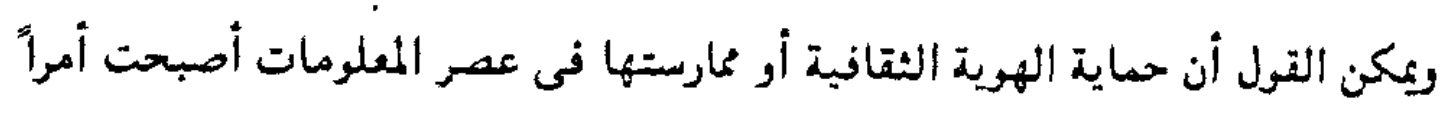

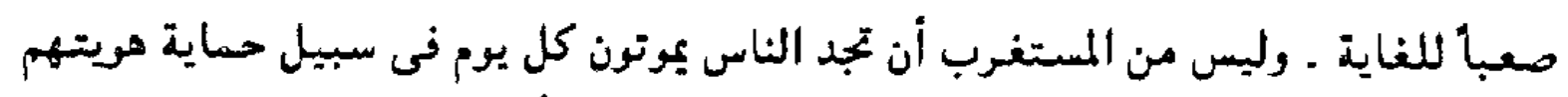

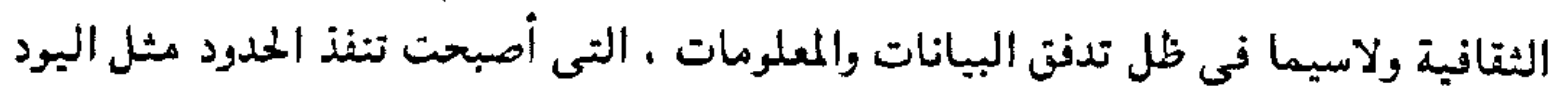

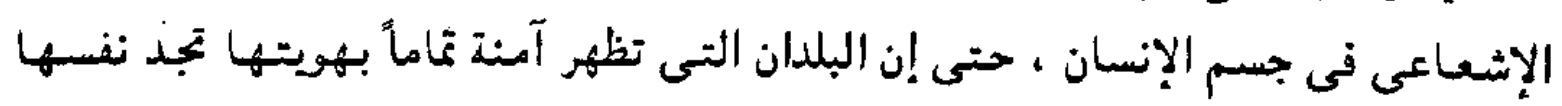


البث التلبنزيونى المباشر

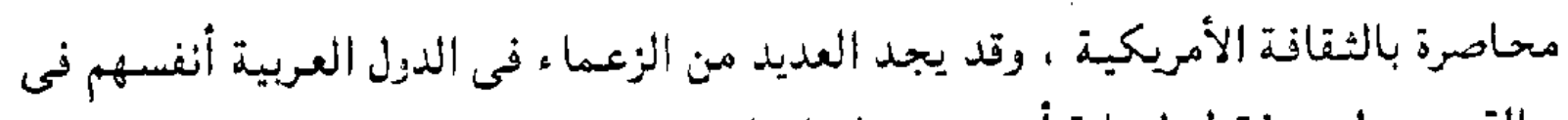

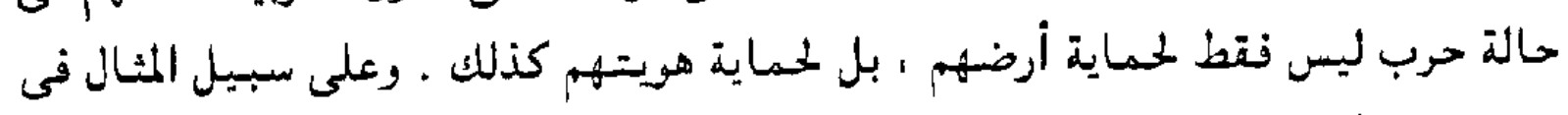

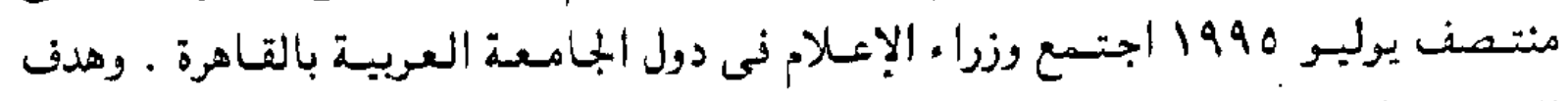

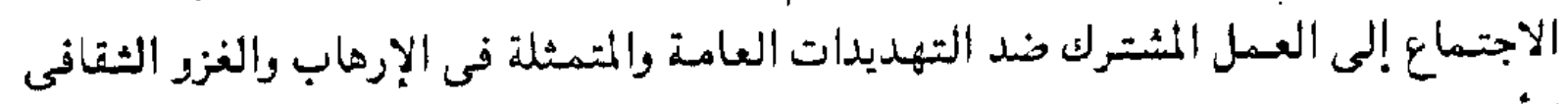

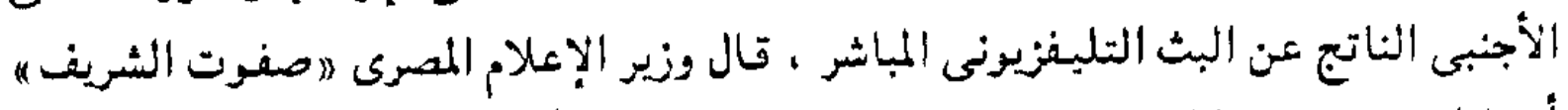

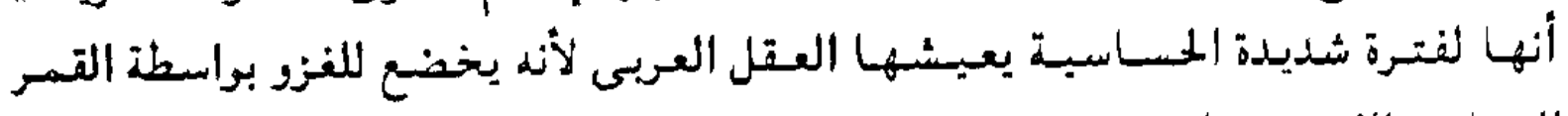

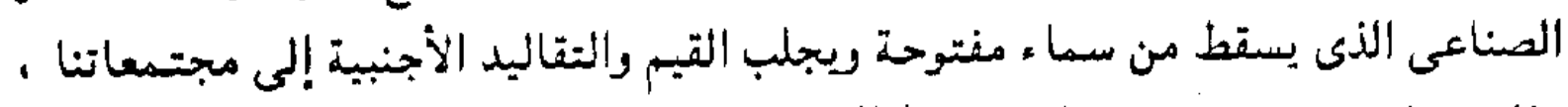

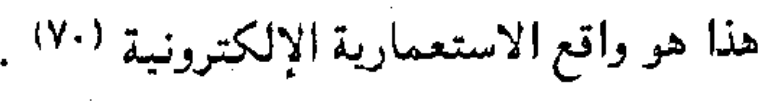




\section{خاتهة ، النتانج العاملة للدراسة}

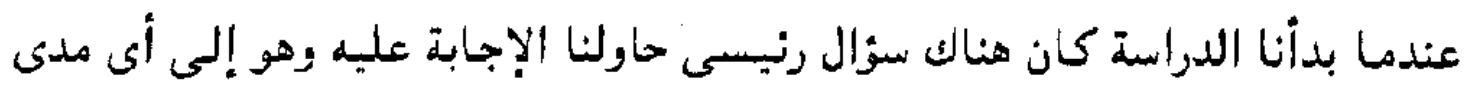

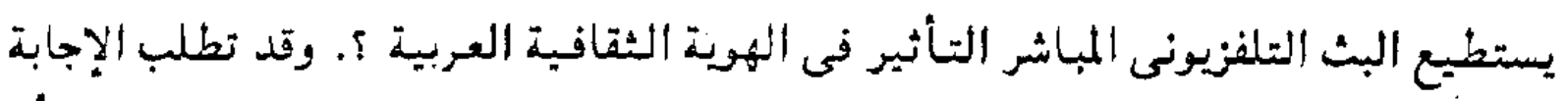

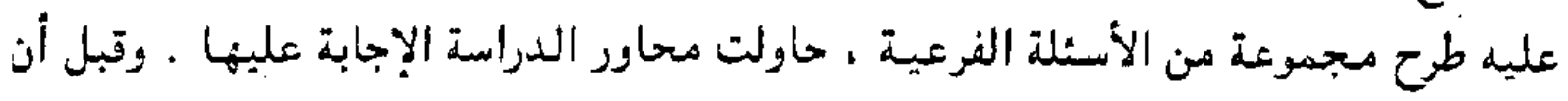

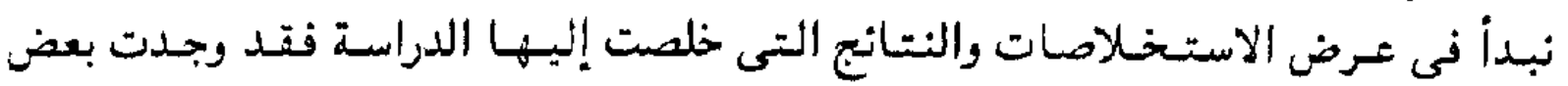

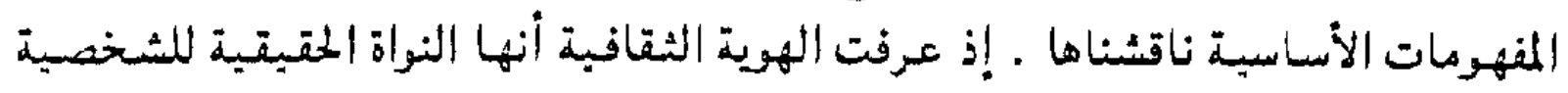

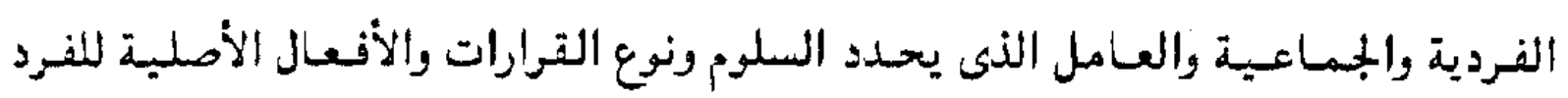

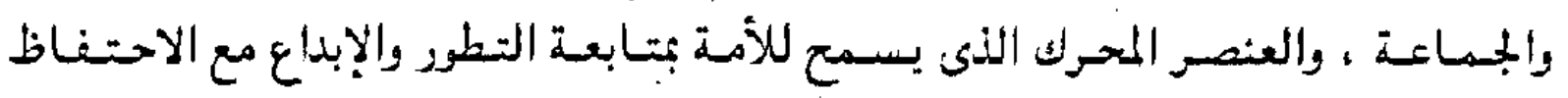

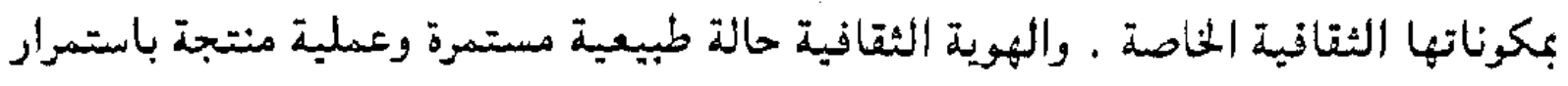

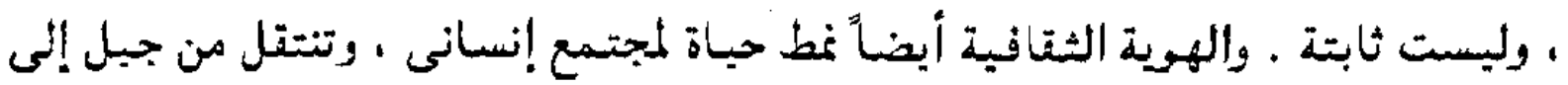

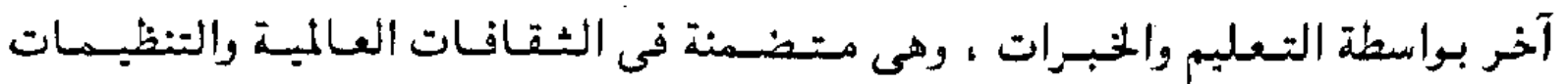

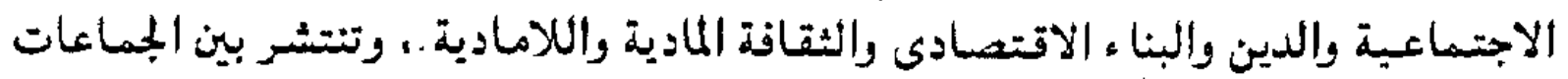

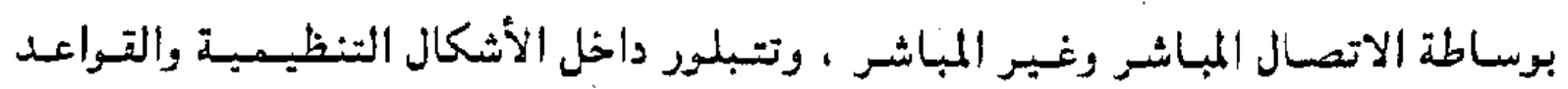

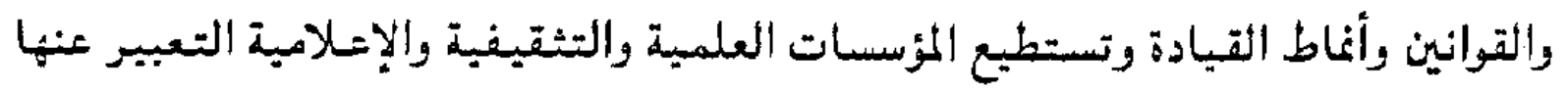

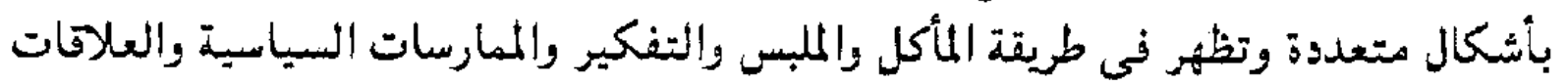

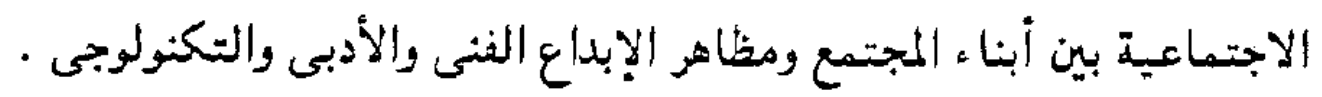

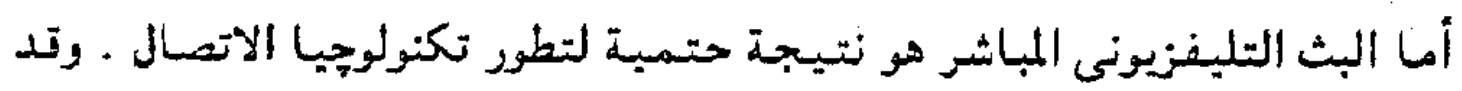

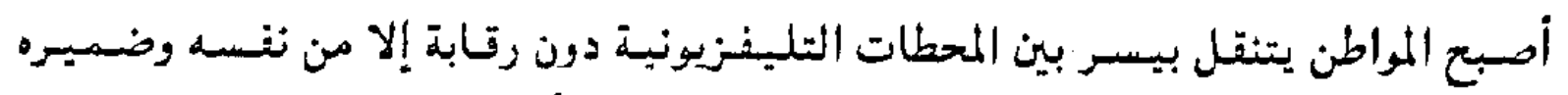

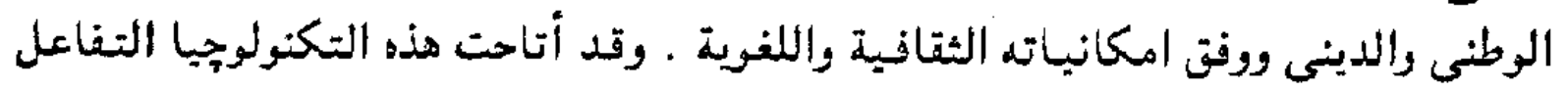

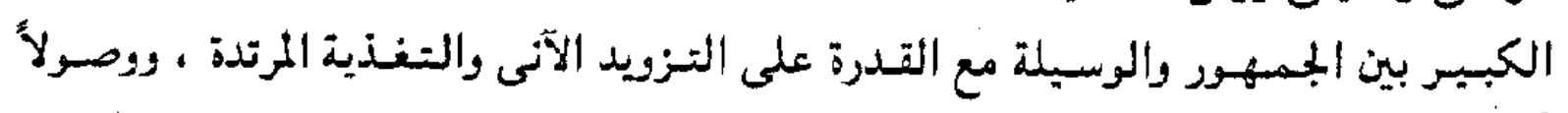

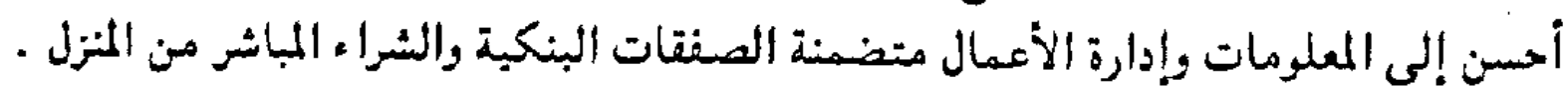

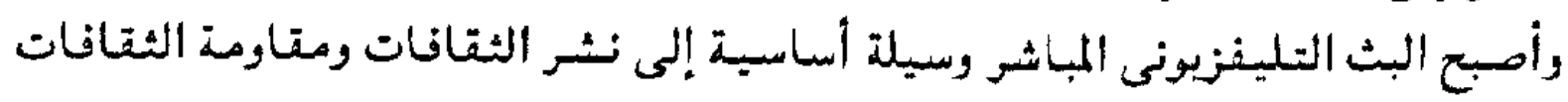

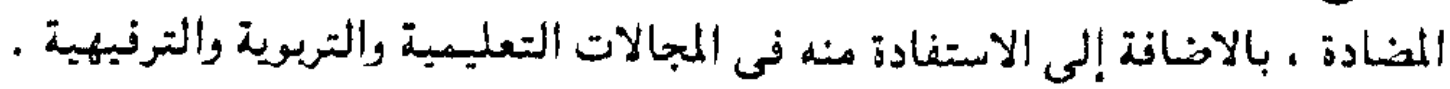

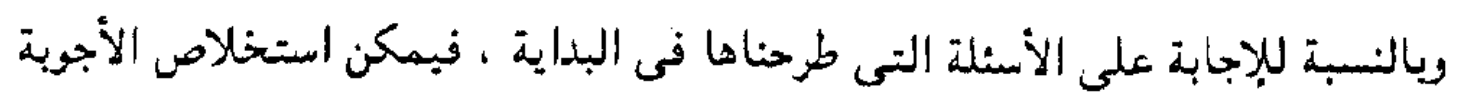

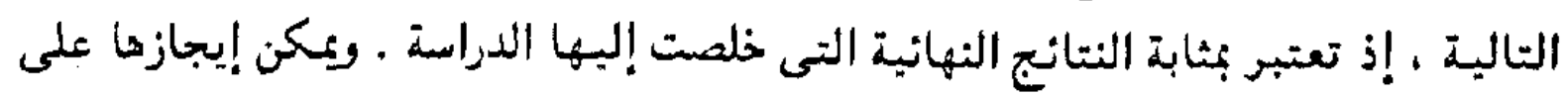

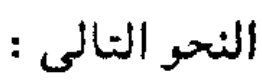

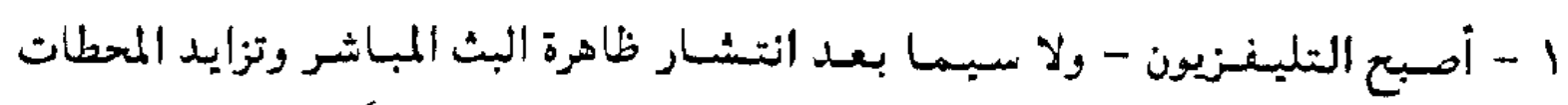

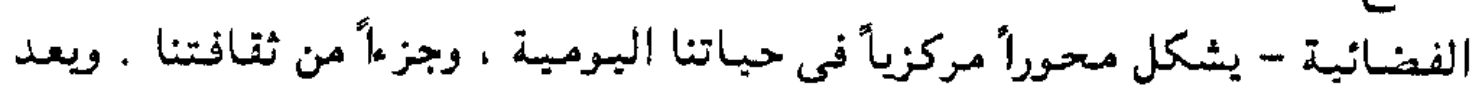




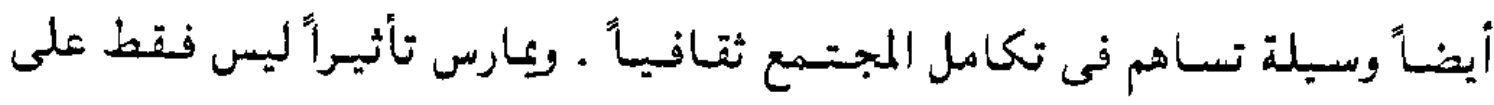

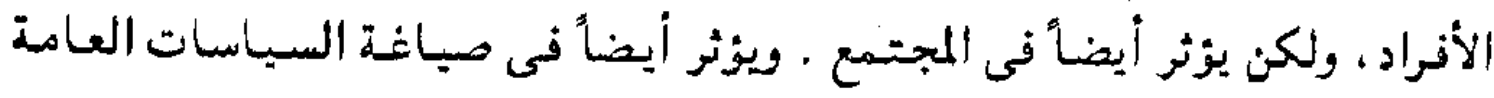

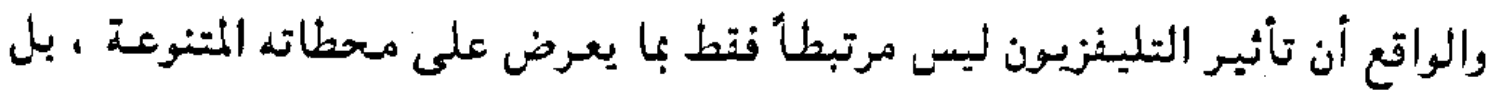

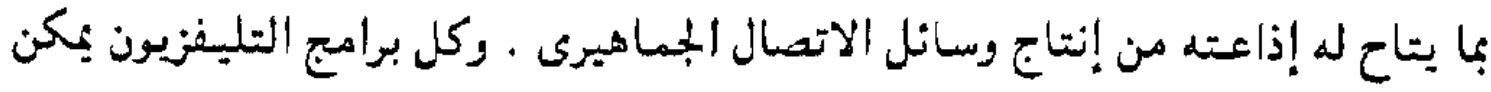

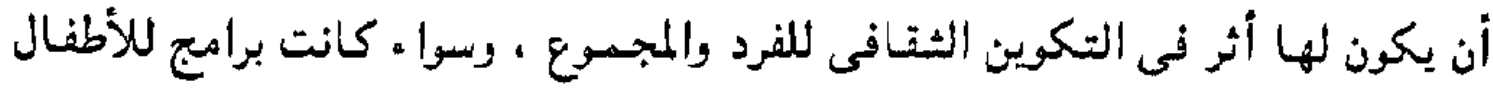

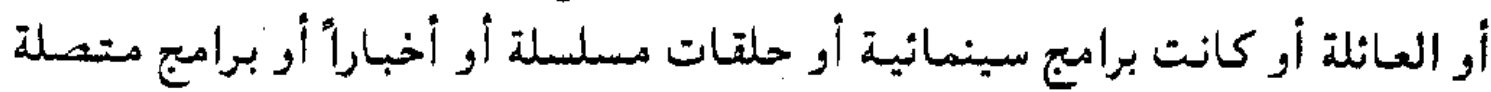

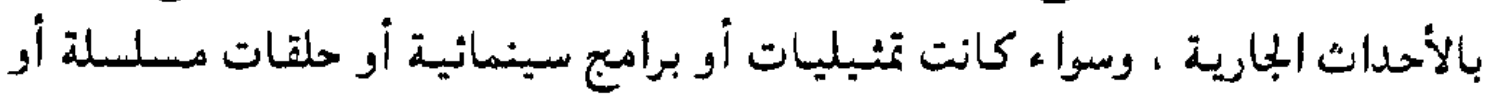

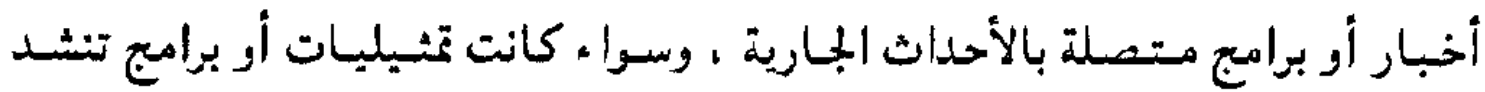

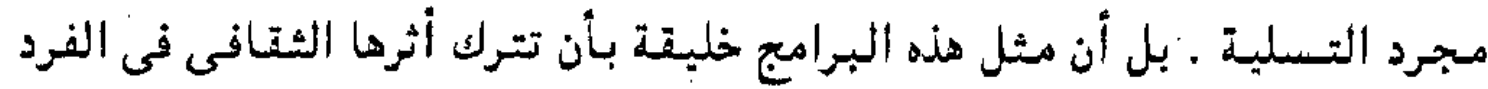

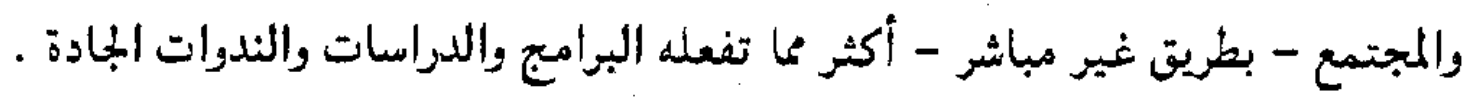

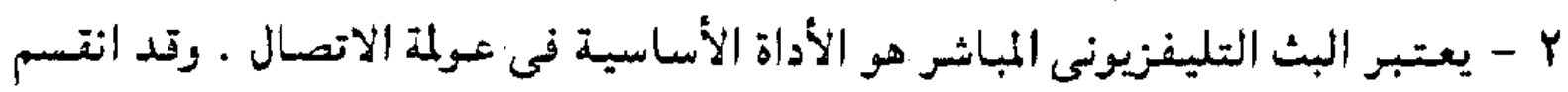

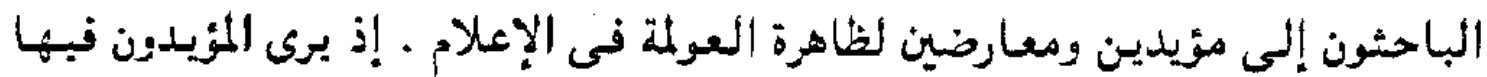

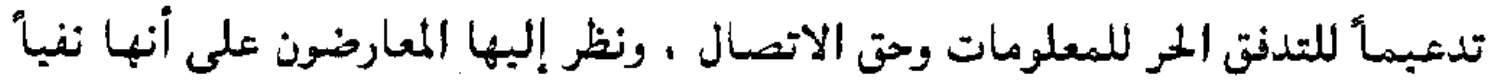

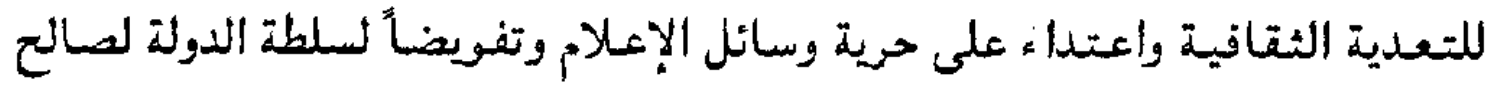

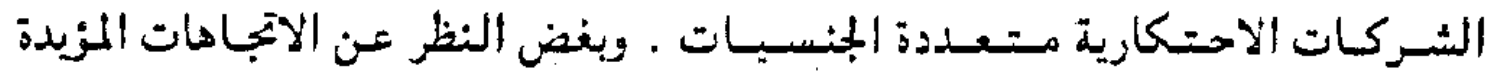
والمعارضة ، هناك حقيقة مؤكدة بأن الثورة التكنولوجية فى دجال الاتصال والمعلومات

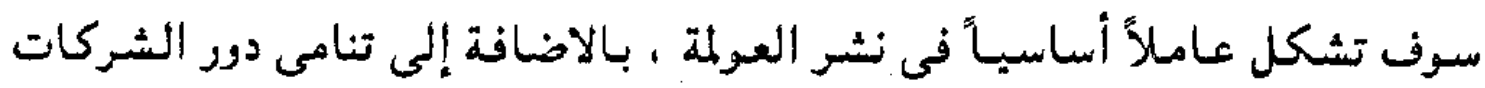

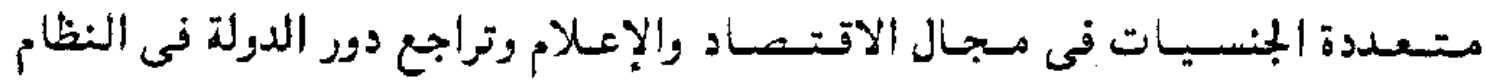
الإعلامى العالمى الجديد ولا سبما في مجال البث الإذاعى والتليفزيونى .

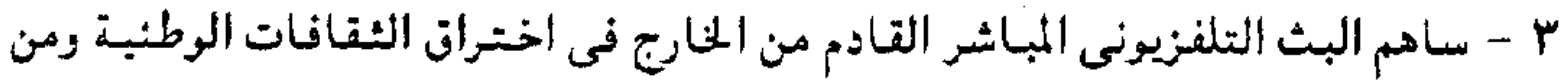

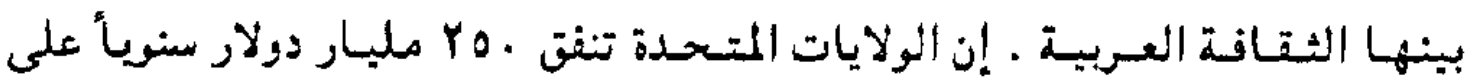

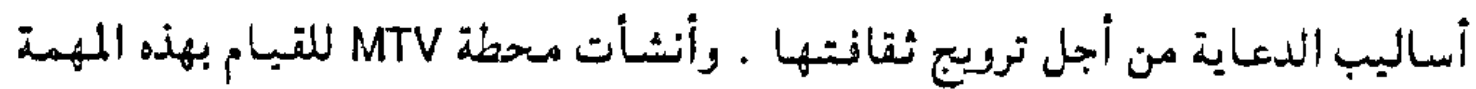

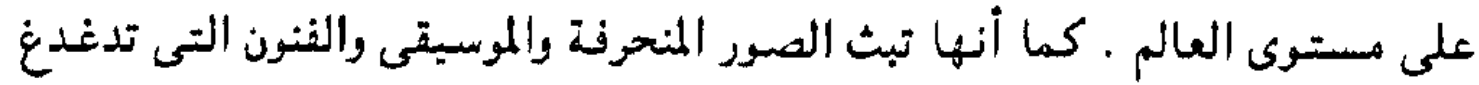

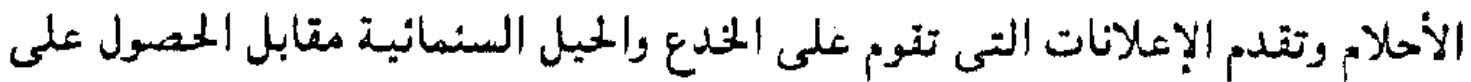

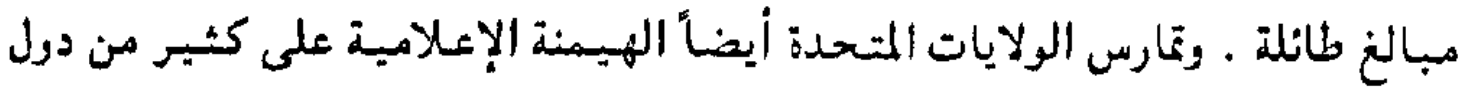

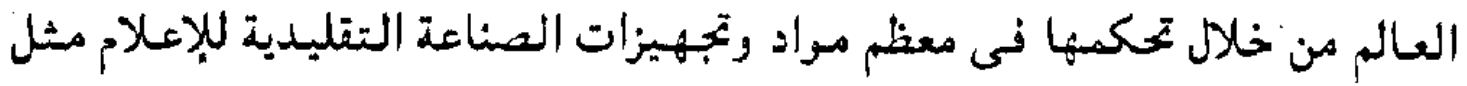

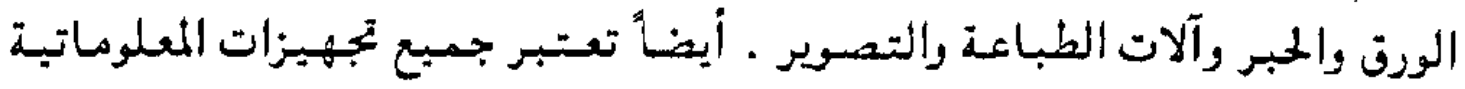

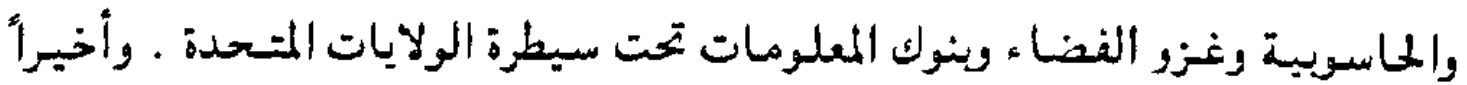




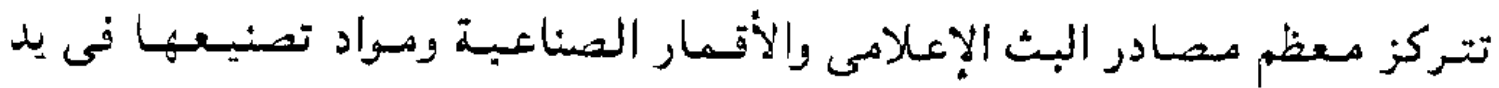

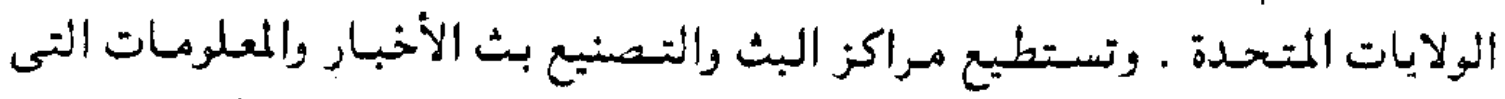

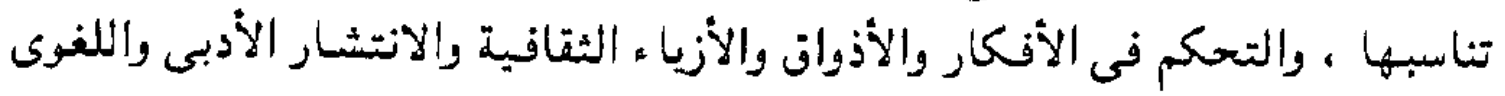

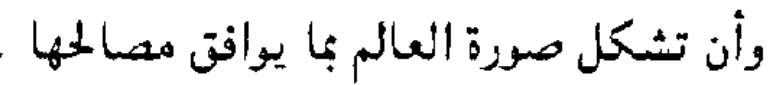

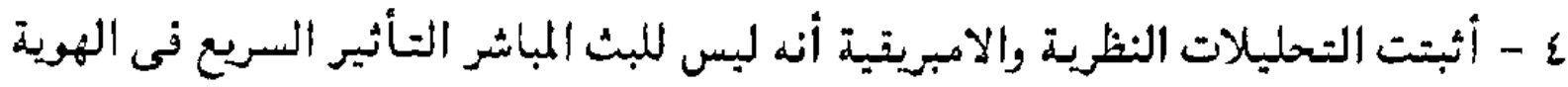

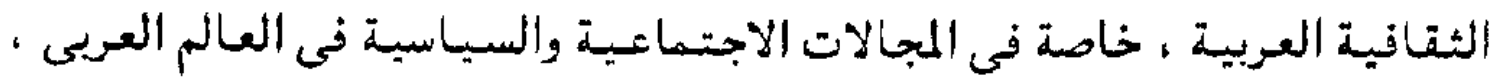

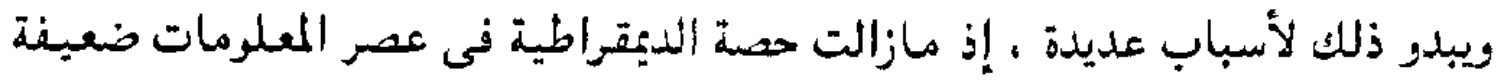

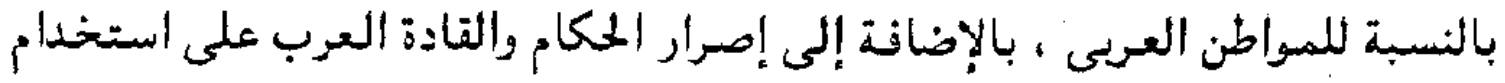

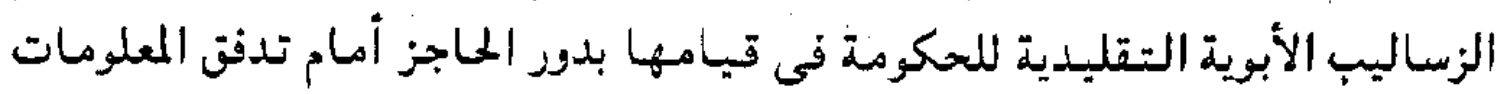

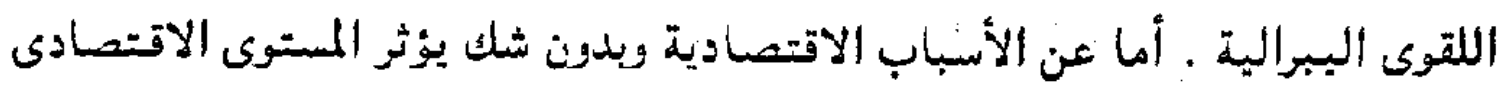

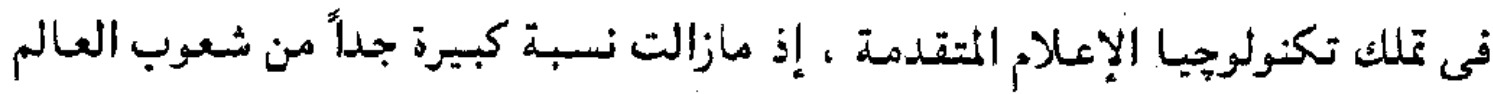

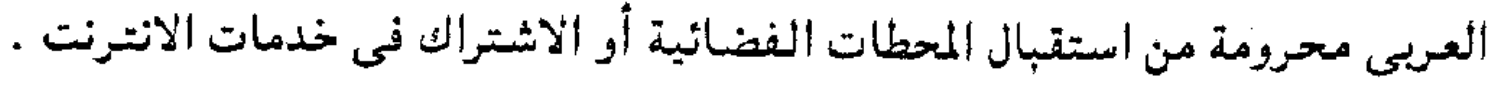

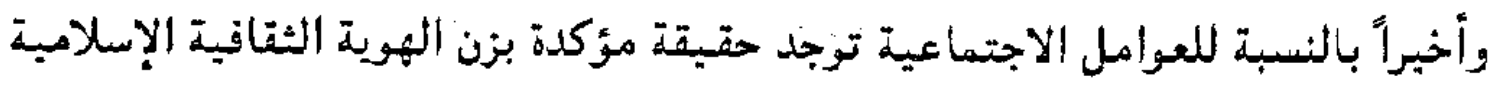

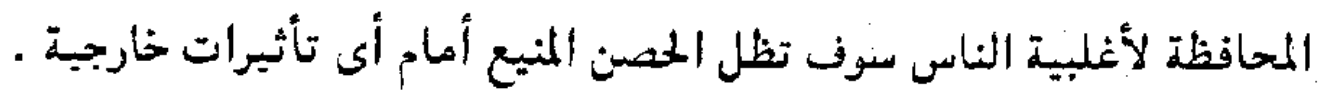

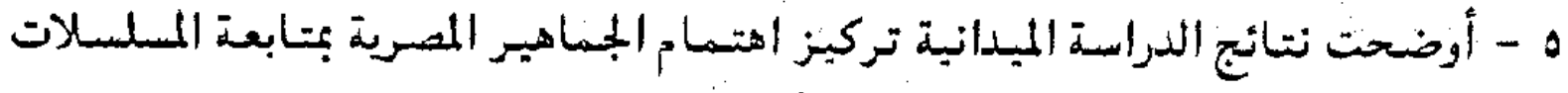

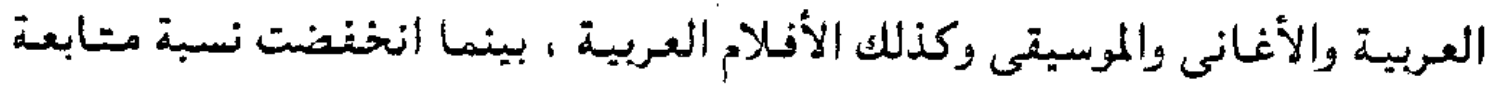

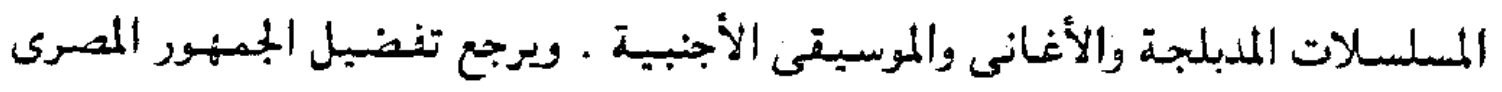

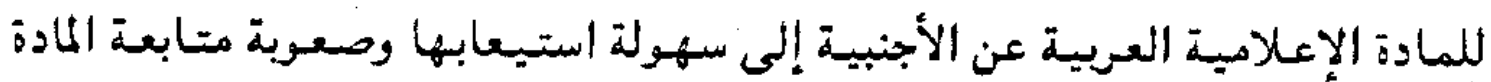

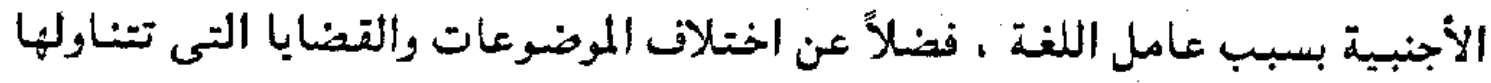

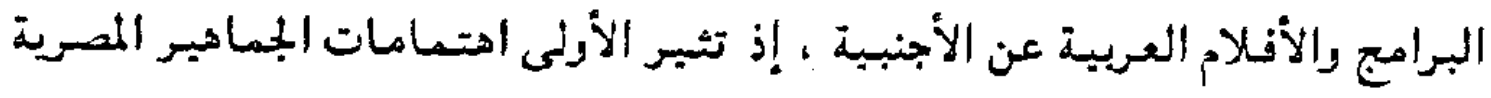

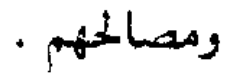

1 - أشارت نتاثج الدراسة إلى وجود تباين فى وجهات النظر بشأن مجموعة من القضايا

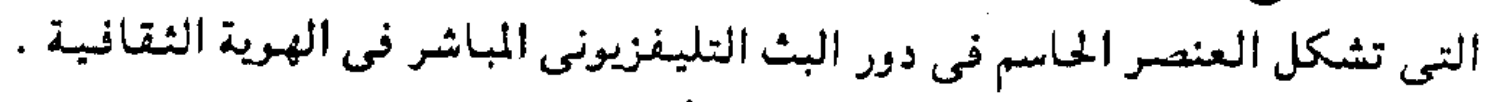

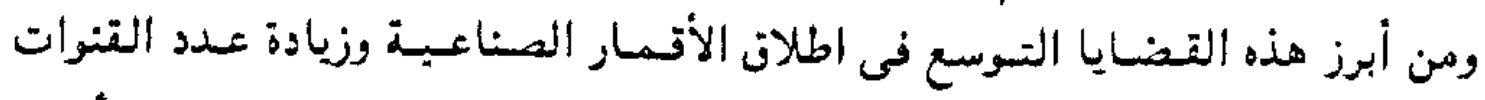

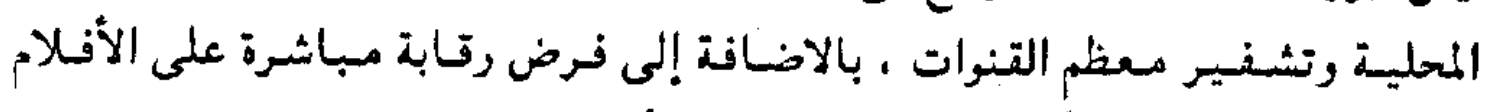

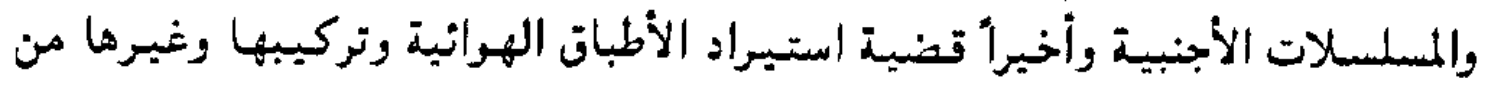

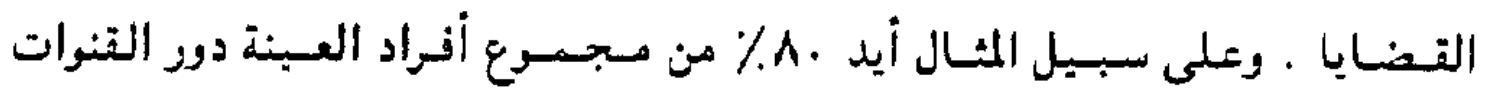

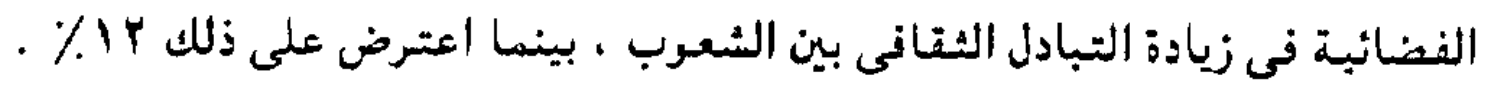




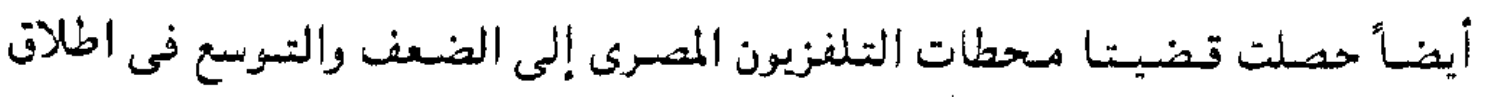

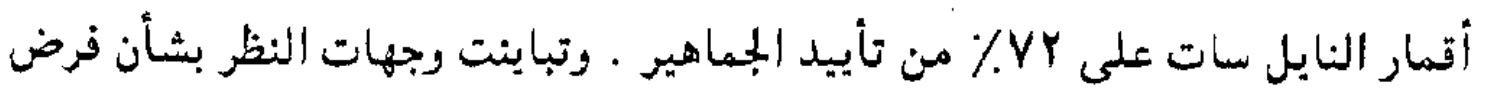

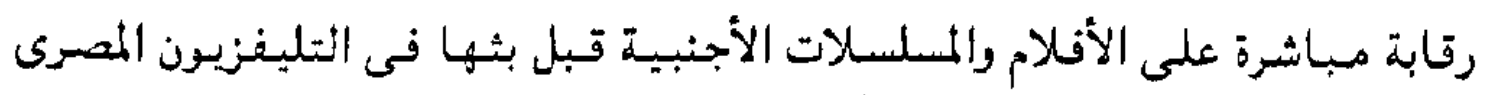

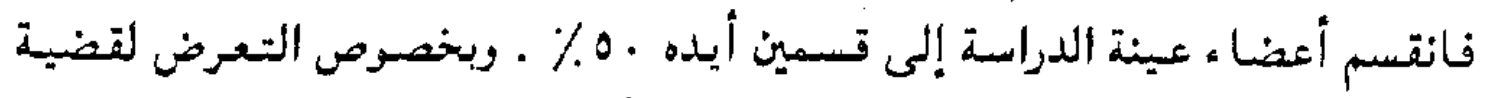

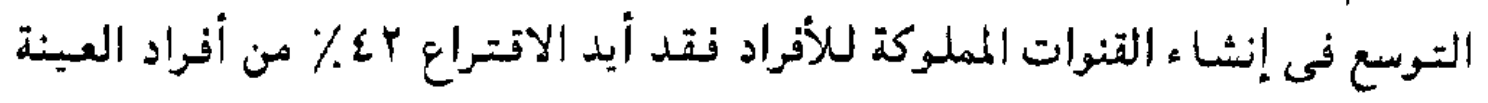

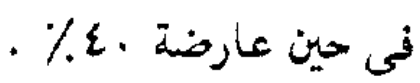

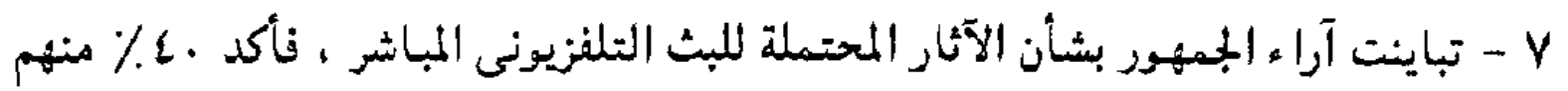

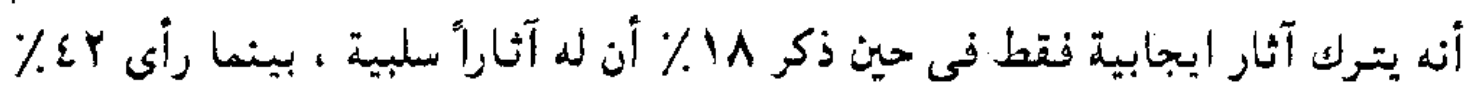

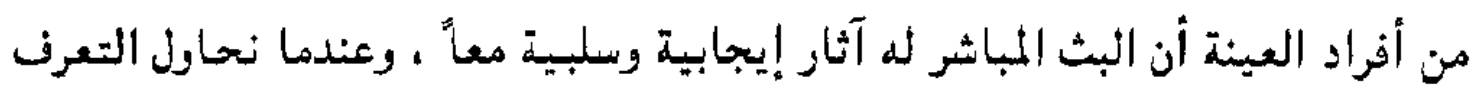

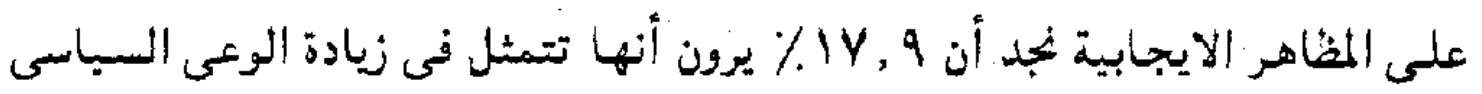

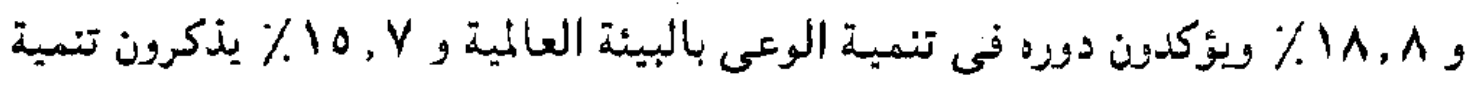

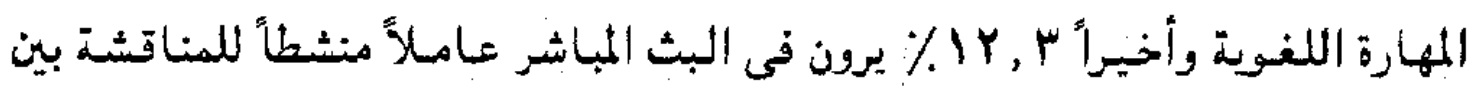
القنوات بعضها وبعض .

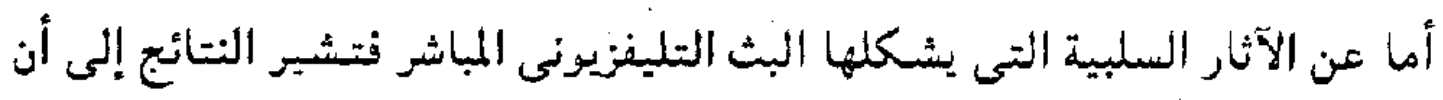

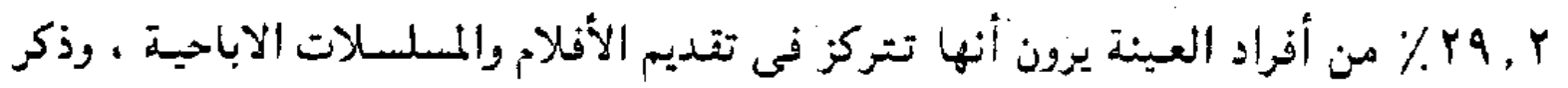

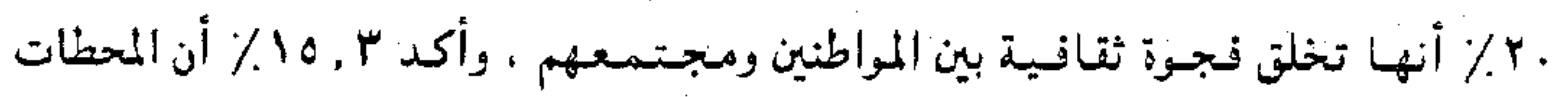

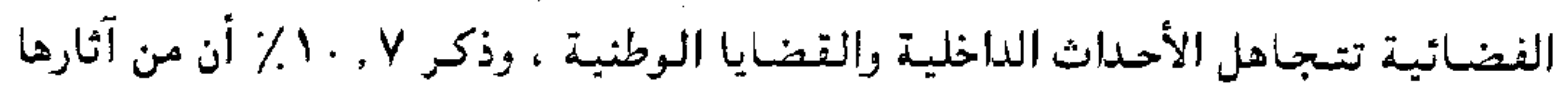

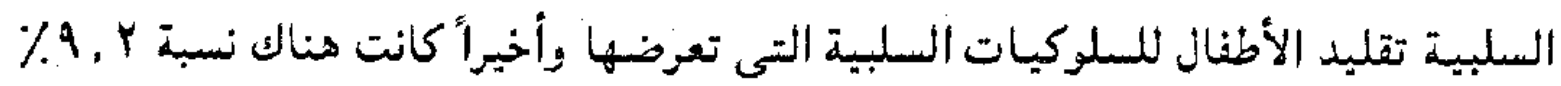

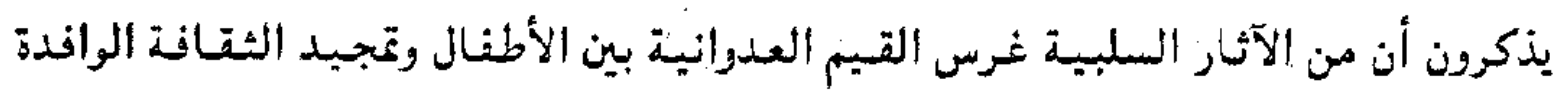

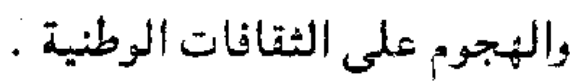

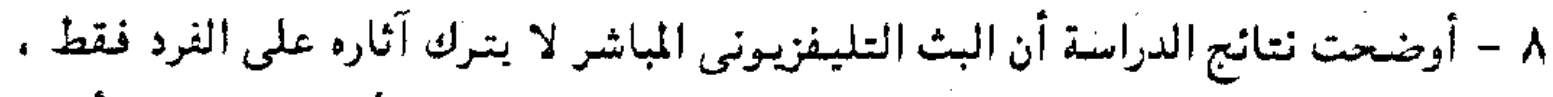

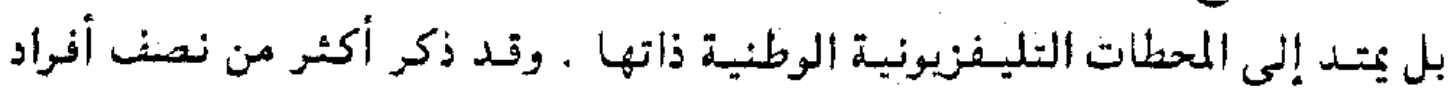

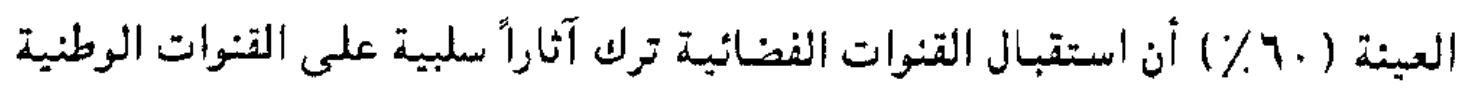

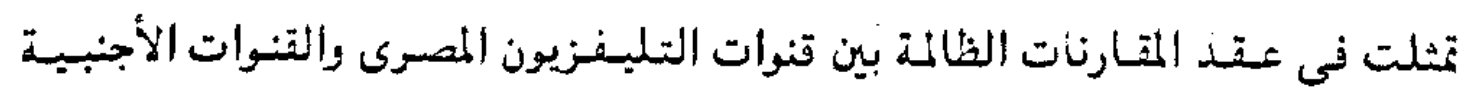

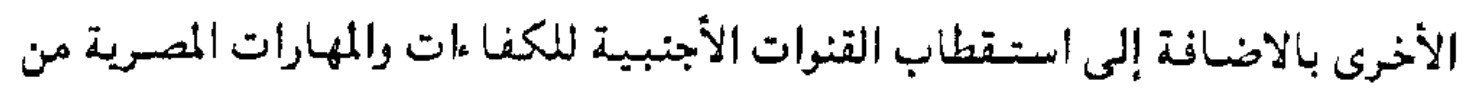

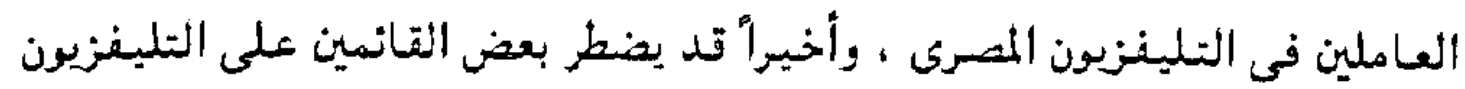

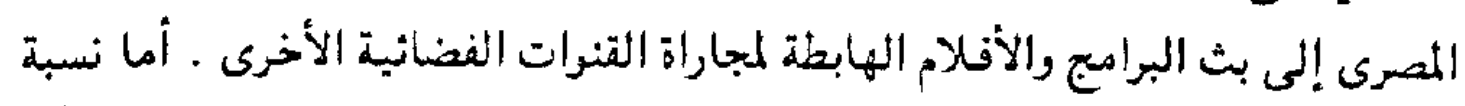

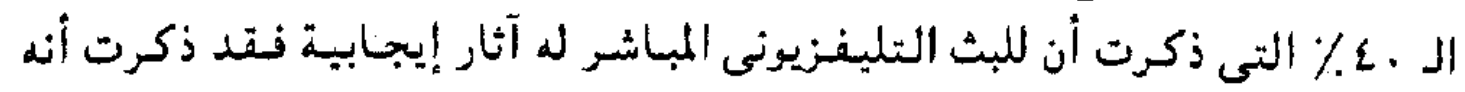


يساهم فى تطوير البراهج التليفزيونية تكنيكاً ومضمسناً ، ريساهم أيضاً فى تنبية

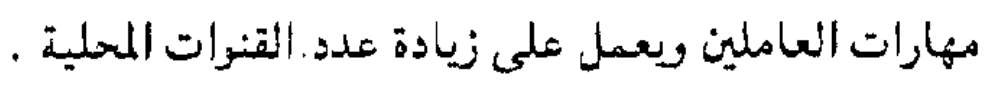

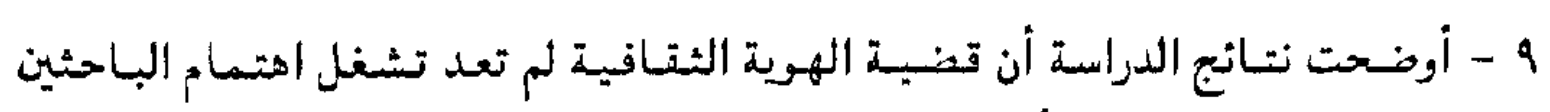

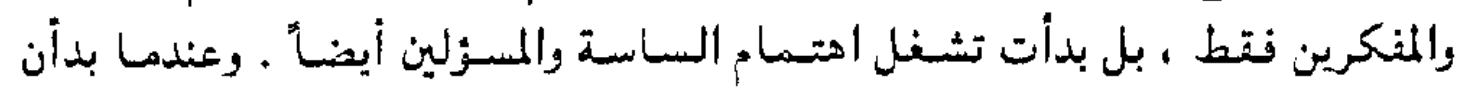

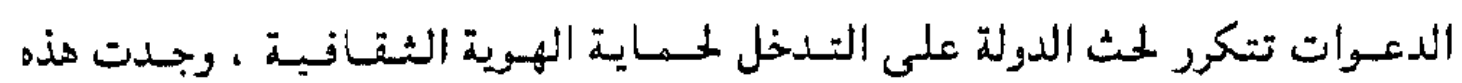

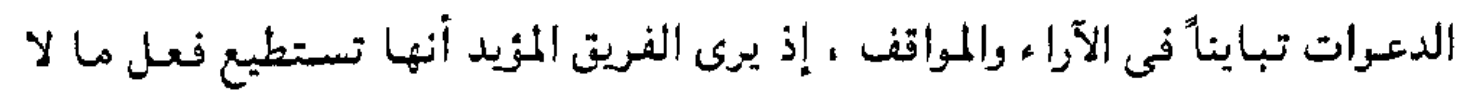

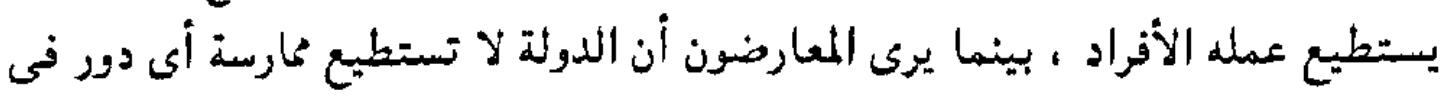

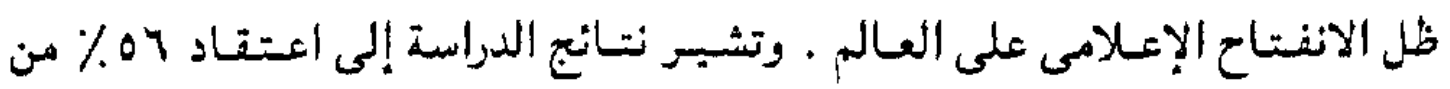

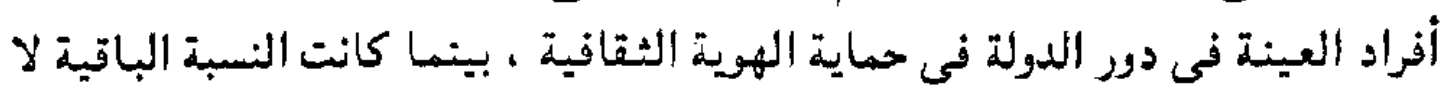

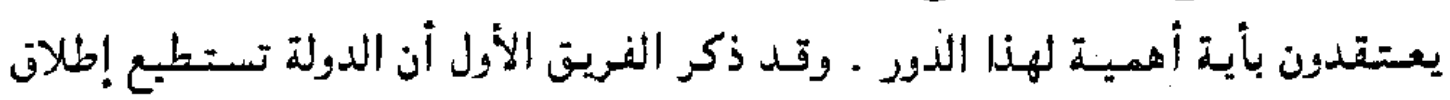

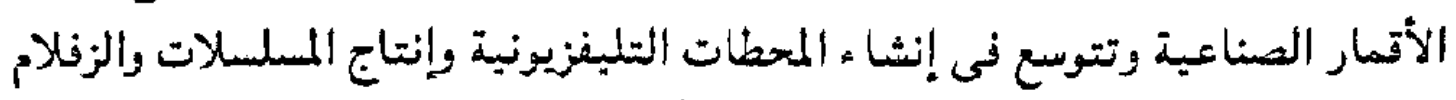

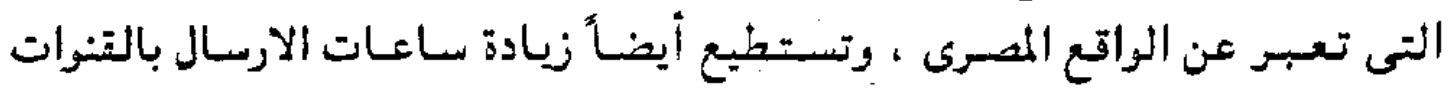

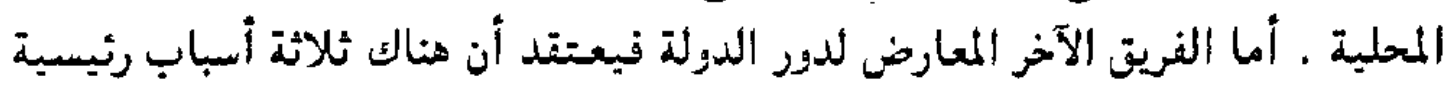

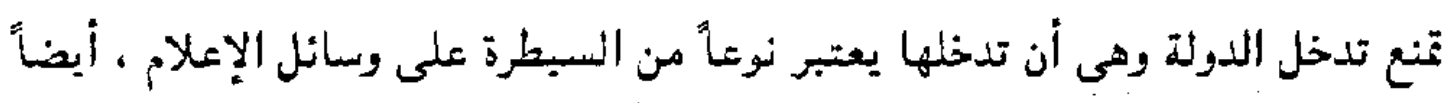

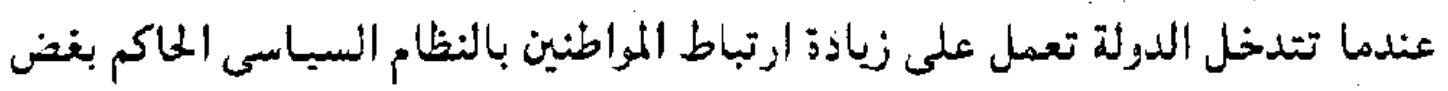

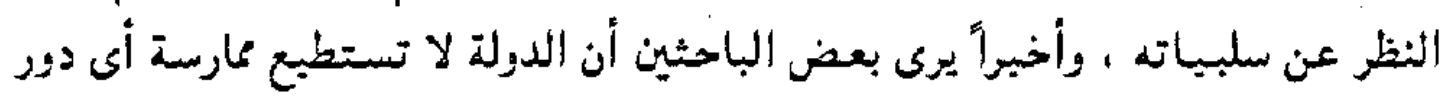

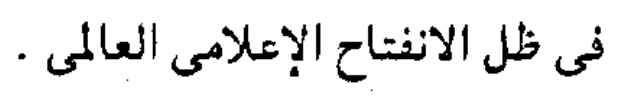

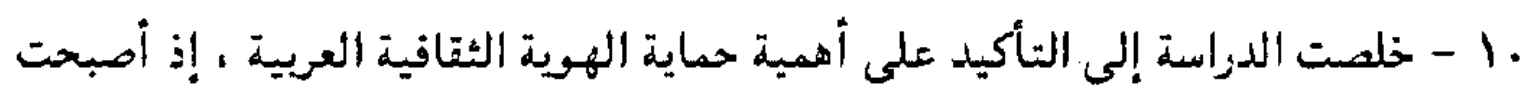

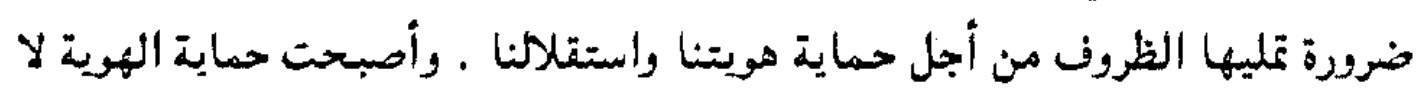

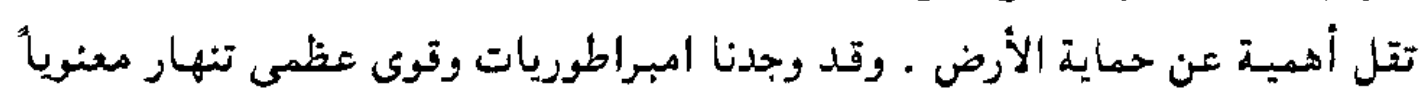

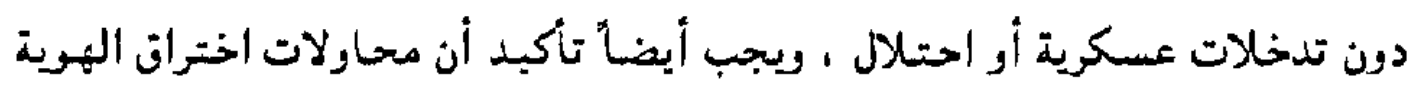

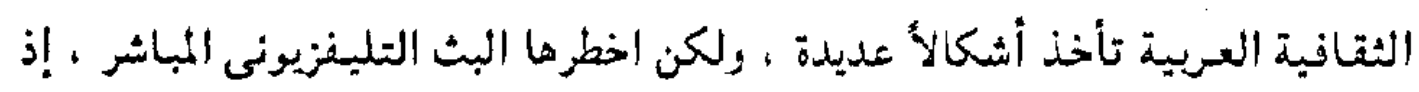

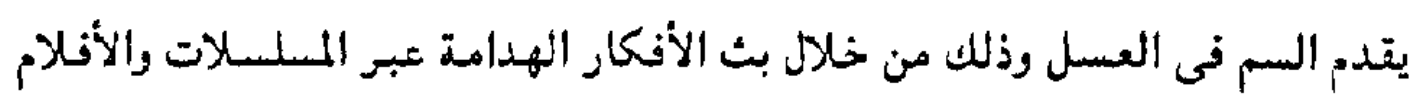
الجذابة ـ ولذلك يجب معاملة هذا الوضع بتحصين ثقافتينا والتأكيد على مبادئنا

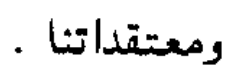

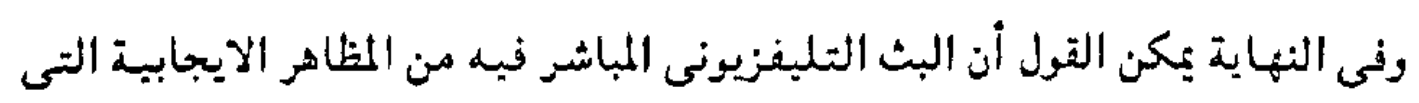

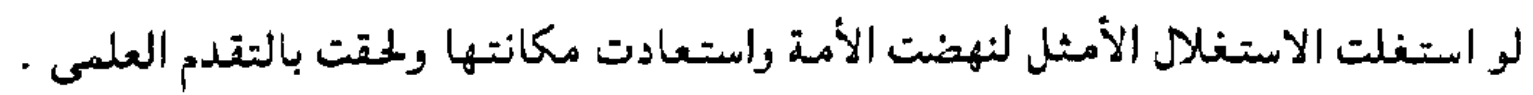

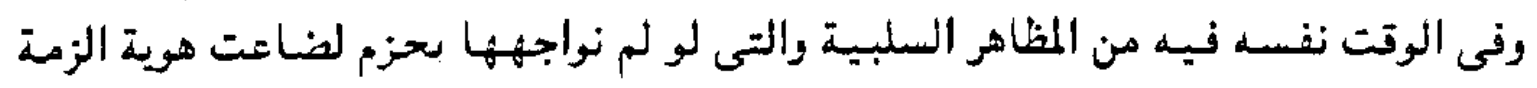


وذابت ثتانتها بين الثقافات الوافلدة ـ ـوعلاوة على ذلك تبقى حقيقة هامة وهى أنه أصبح

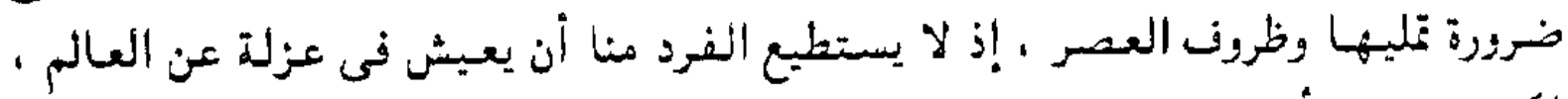

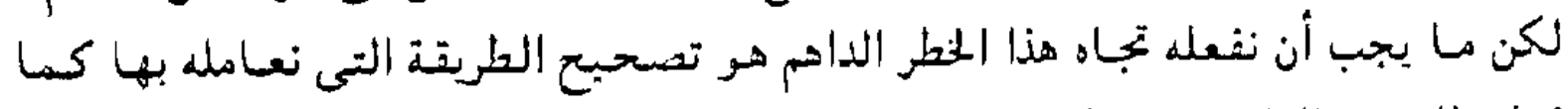

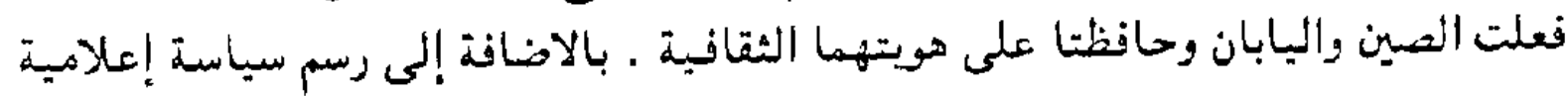

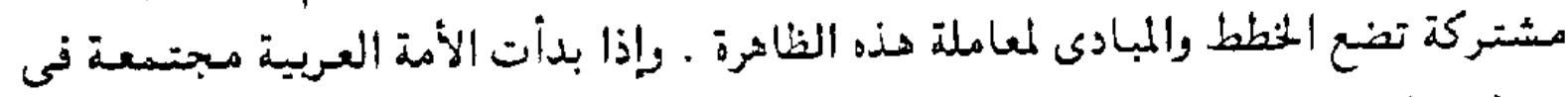

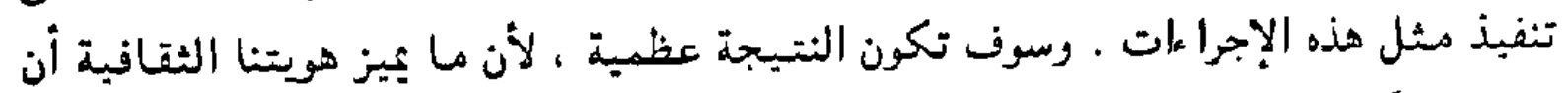
لها جذوراً مستمدة قواعدها من الدين الإسلامى . 


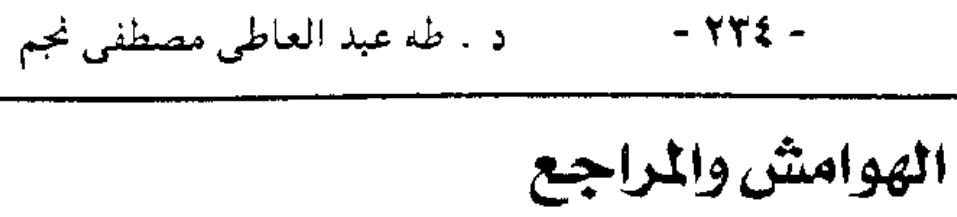

1 - Robin Allet. group identity and national identity. www//multural mining, co com/msub 13.htm.jul. 1999.

r - د ـ محمد سكران ، العولمة والهوية الثقافية - روية نقدية ، ندوة العولمة والخصوصية

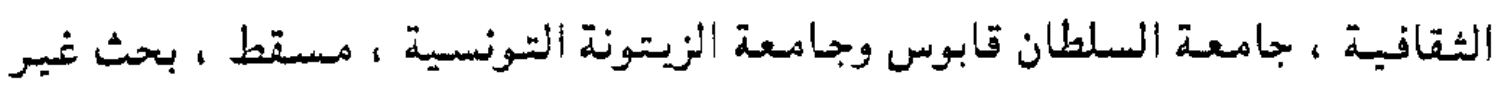

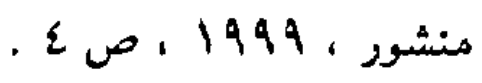

2 - Canadian multiclturalism : Cultural identity, http//wb20 mind link net /stole/ multicul htm 1996.

كُ - الخطة الثاملة للثقافة العربية ، الثنظمة العربية للتريسة والثقافة والعلرم ، المجلد الأول

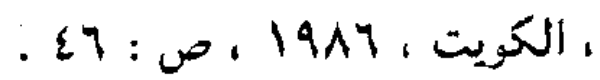

5 - jon servaes \& Rico lie. Toward a more interpretaive communication research "framework". Television as cultural system. an interpretation of clifford Geertz.

http:www.unisa.ac.za/dept/press/com ca/221/servaes.htm/.p:4.

6 - Chris Barker. Global television - an introduction. black well publishers. London. 1997. P:194.

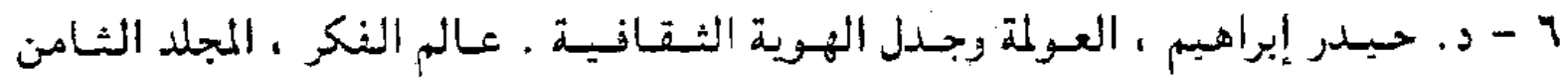

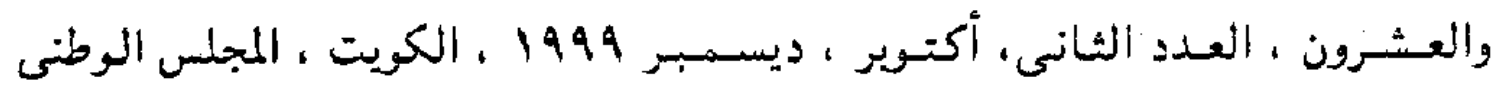

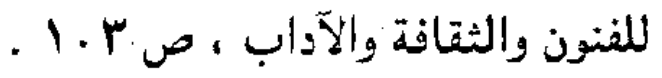

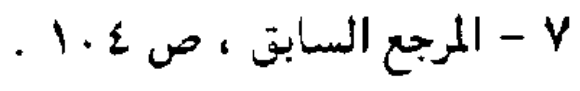

^ - جلال عبد الفتـاح ، البث الإذاعى والتليفزيونى المباشر ، الجزء الثانى ، الهيئة المصرية

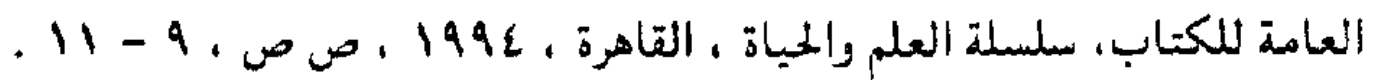

9 - Colin J. Knowles, digital technology-Catalyst or inhibitor of future cultural and sond social exchange. http:www.yu.au/center/pp:1-2.

ـ 1 - د. توفيتي يعقوب ، حول الهوائيات ، مسجلة الإزاعة العربية ، اتحاد إذاعات الدول

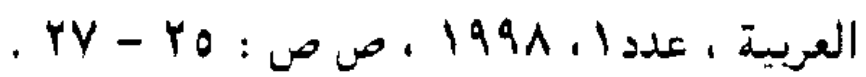

$$
\begin{aligned}
& 11 \text { - المرجع السابت ، ص ص : צY ، Y . } \\
& \text { Ir - المرجع السابق ، ص ص : YY }
\end{aligned}
$$


البث التليفزيونى الباشر

13 - Tom O'regan. TV as cultural technology: The work of Eric Michaels. The Australian journal of media \& culture, vol.3. 1990. http://kalimurdoch.edu.an/ continuum/EM work.

14 - ibi.p:3.

15 - Moira Rayner, cultural identity in the age of glolal Television, http://ka li murdoch.edu.au.htm.

17

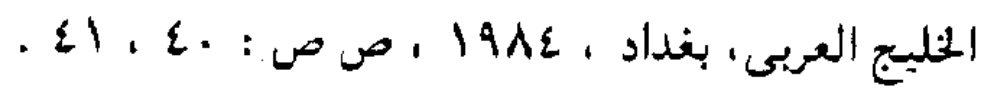

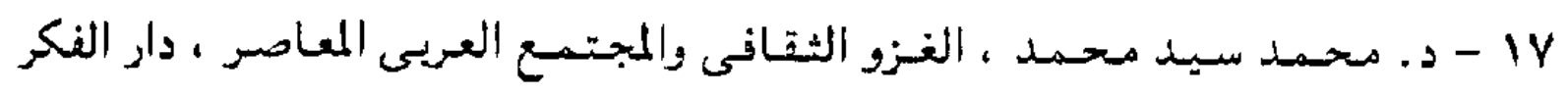

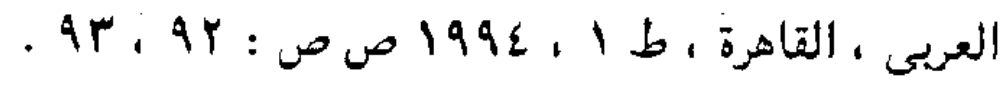

11 - د. طه عـبد العاطى ، الاتصال الجـــاهيسرى ، وار المعرفة الجامعيـة ، الإسكندرية . PE . 1991

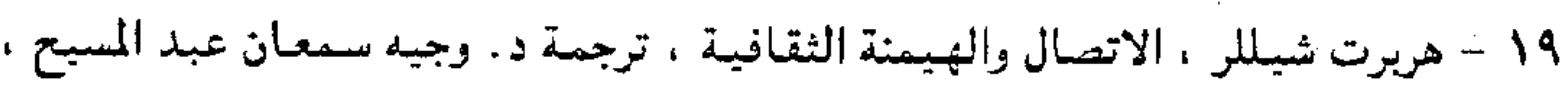

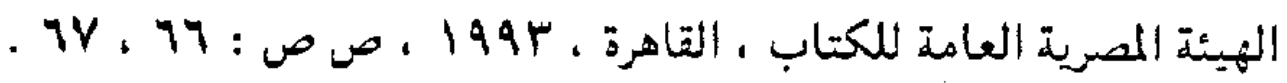
r - د. محمد سكران ، مرجع سابق ، ص ص : 9 ، . . . .

ا Y - د. عبد القادر الهيتى ، ثقافتنا والعـولة ، ندوة العبولة والملصوصية الثقافيـة ،

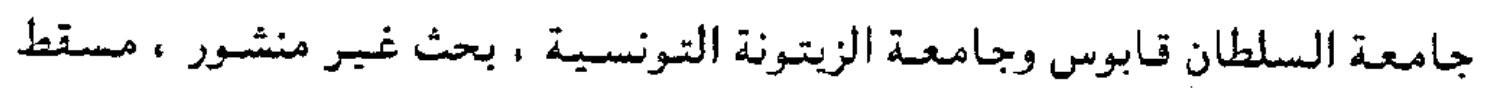

$$
\text { .r. r: r : 1999 }
$$

22 - Robin Allott, op. eit.

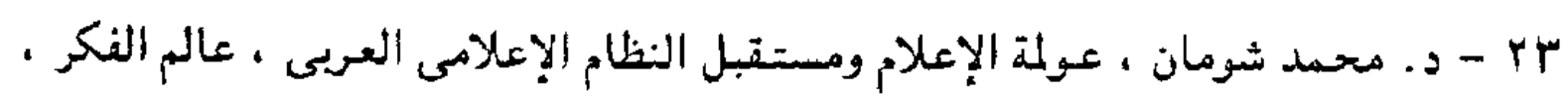

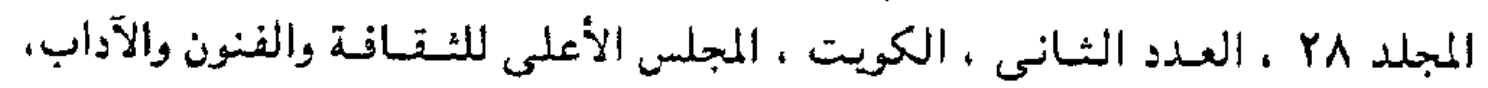

$$
\begin{aligned}
& \text { أكتوير - ديسمبر 1999 المليد ، ص: } 109 \text {. } \\
& \text { ك ا T - المرجع السابق ، ص : .17 . }
\end{aligned}
$$

25 - Communication and culture transture transformaton - cultural diversity. globalization and cultural convergence. project ptesent to the European $\begin{array}{llll}\text { university. Barceland. june } 1998 . & \text { Http/lwww.steph } \\ \text { web.capstone/htm/1998/p:1. } & & \end{array}$

26 - ibid.p:1. 


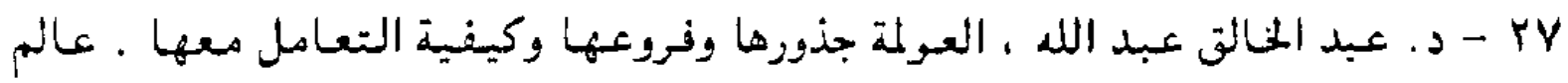

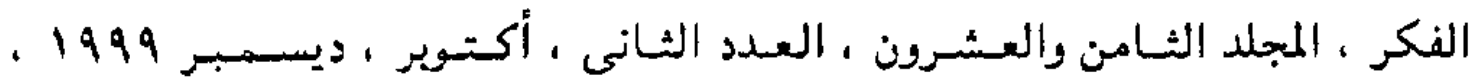

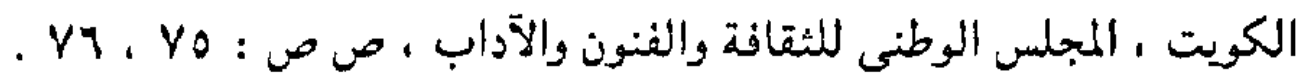

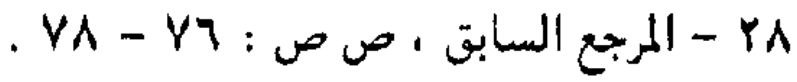

$$
\begin{aligned}
& \text { Y9 - د. حيدر إبراهيم . مرجع سابق ، ص ص : ه. } 1 \text { ، } 7 \text {. } 1 . \\
& \text {. r - د. محمد سكران ، مرجع سابق ، ص : Ir. }
\end{aligned}
$$

31. Houda Gamal Abdul Nassr. Arabs. Arab- Americans and globalization. www.aihewar.com/HGAnasser.htm. 1999.pp:1-2.

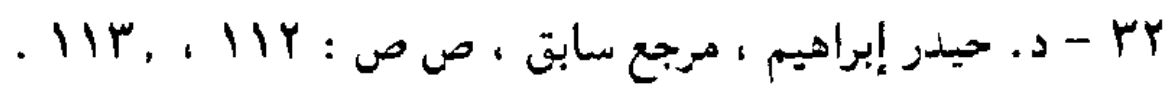

بr - د. سميح مرسون ، الثقافة والتبعية - الغزو الثقافى للعالم العربى ، الخطة الثاملة

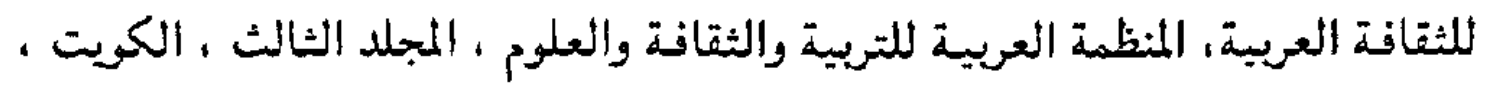

$$
\text { . IINV: : 1917 }
$$

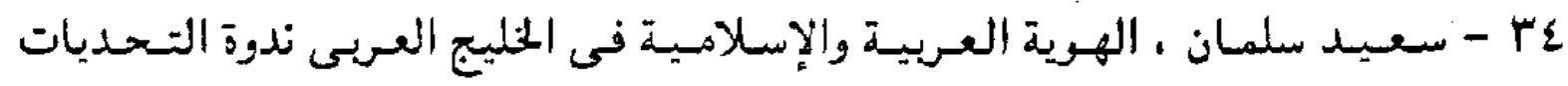

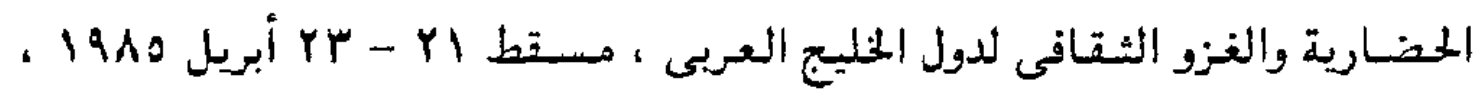

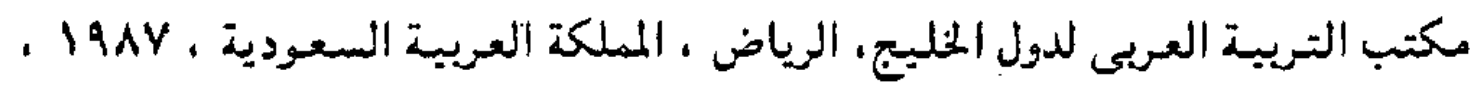

$$
\begin{aligned}
& \text { ص : IV }
\end{aligned}
$$

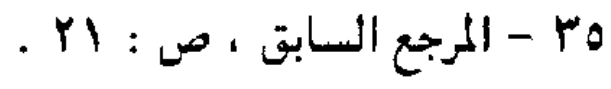

36 - Nizamid Din Missaghi. Two definition of the word "Arab": Arab identiy through two epectacles Eastern and western. http://www.people.virginia.gdu/amh 2x/aso/kalimat.htm. 1998.pp:2.

37 - Sadek jawad Sulaiman, understanding our culture : A question of identity, www.alhewar.com/culture.htm/p:2.

38 - ibid.

39 - ibid.

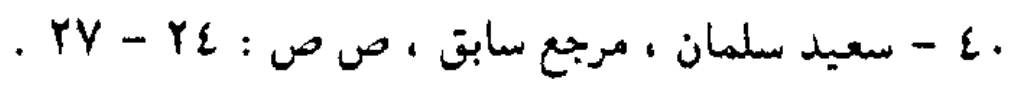

اكـ - الفين توفلر ، تحارل السلطة ، ترجمة لبنى الريدى ، الجززء الثانى ، الهيمنة المصرية

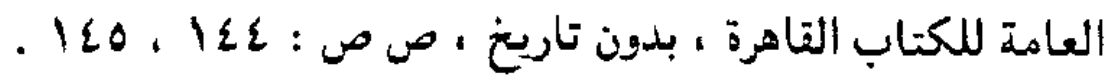



د . طم عبد العاطى مصطنى نجم

42 - Deborah Wheeler. New Communication Technologies. Human rights. development and the defense of middle easten eultural space. wrl. ulexas. edu/"monitors"/1.1/wheeler/oneddocwhewheeler. htm.

43 - Stanley J. Baran. Dennis K. Davis, Mass communication theory foundations - forment and future. madsdsmoth publishing company California. 1995. p:330.

$$
\text { ع - و. دمحد سكران ، مرجع سابق ، ص : Ir }
$$

هـ - د. حسام الخطيب ، أى افق للثقافة العربيـة وآوابها فى عصر الاتصال والعولمة ،

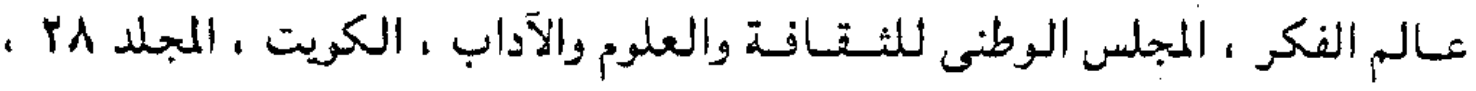

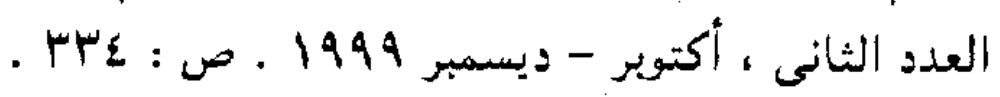

46 - Chris Barker. Global Television - an introduction, Black well publishers, London, 1997.p:184.

47 - ibid., : 184.

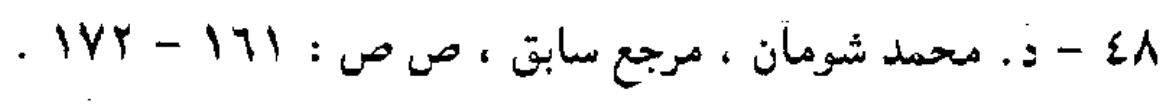

49 - Stuart Hall. culture. The media, and ideological effeets, in : james curran. mass communication and society, The open university, 1979 , pp ; 315,316.

50 - ibid., pp:418,319.

51 - Moira Raymer. Cutural identity in the age of global television. op. Cit,.

52 - ibid.

53 - Deborah Wheeler, op.eit.

54 - ibid.

55 - ibid.

56 - ibid.

57 - Moira Raymer, op. cit.,

58 - ibid.

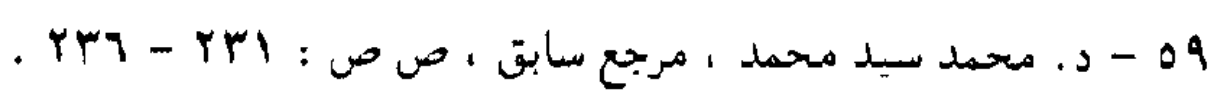

. 1 - روبير أنسيو ، الغرب والعرب - هذم وبناء الهوية الثقافية ، مجلة القاهرة ، الهيئة

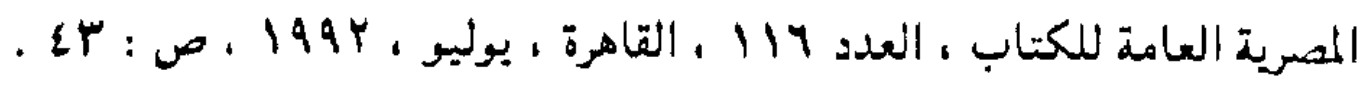
الو - ألفت حسن آغا ، البث المباشر والهوية الثقافية ، وراسات إعلامية ، أبريل - يونيو 


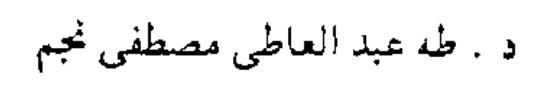

- MrA -

البث التليفزيونى المباشر

62 - Deborah Wheeler. op. cit.,

63 - ibid.

64 - Moira Raymer., op. cit.,

65 - Deborah Wheeler. op. cit.,

66 - Houda Gama Abdul Nasser, op. cit. p:2.

TV - د. عبد القادر الهيتى ، مرجع سابق ، ص : 10 .

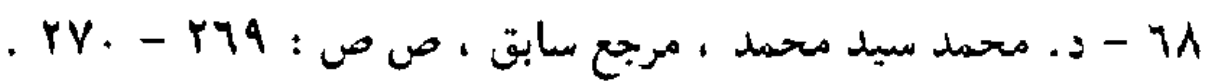

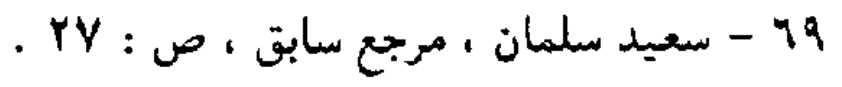

70 - Deborah Wheeler., op. cit. 